\title{
APPLICATION FOR PERMIT TO OPERATE A CLASS II SOLID WASTE DISPOSAL SITE AT THE NEVADA TEST SITE
}

\section{U10C DISPOSAL SITE}

\author{
March 2010 \\ Rev. 0
}

Prepared for the

U.S. National Nuclear Security Administration

Department of Energy

Nevada Site Office

by

National Security Technologies, LLC 


\section{Table of Contents}

List of Tables

List of Aclonyms $\quad$ J\%

10 Applicant Information 1

20 Facility Infolmation $\quad 1$

30 Policy 1

40 Notulication 2

50 Backglound Summaly 2

60 Waste Character uzation Plan 4

61 Summaly 4

62 Waste Acceptance Culteis 4

63 Waste Claracter zzation 9

70 Design Report 10

7 J Desrgn lnformatron 10

72 Types, Quantitıes, and Sowees of Waste

73 Hydrogeologe Charactenstics 13

74 Climate

75 Runon and Runolf Connol 14

80 Water Monilou ing Plan 20

81 Gioundwatel Monteloug Warve 20

82 Montoumg System 2]

90 Operabng Plan 23

9 I Collection and Tianspontaloon 23

92 Persomel 23

93 Piocessigg In 23

94 Off-Loading 23

95 Daly Loy

96 Random Inspectoons 24

97 Signage/Hours ofOpetalion 24

98 Disposal Stte Equipment 24

99 Opelating Recolds 25

910 Covel and L1ft Conto] 25

911 Dust Contol 26

912 Littel Conthol

913 Vectot Contral 26

914 File Piotection 26

915 Methane Gas:Eyplosive Gas Momtor ing 27

916 Unfoleseen Cycumstances 27 
917 Site Inspectıons 27

9 Solıd Waste Repott 28

100 Closutc Plan 29

110 Post-Closure Plan 3]

120 Refeiences

\section{Lisf of Figures}

Figute I Location of U10C Disposal Site

Figuic 2 Disposal Site Map I/2 Mile Radius (2 ft Contout)

Figule 3 Curent Site and Facılıty Map (5 ft Contour) 16

Figure 4 I0C Crate Expanded Bortow Area 17

Figuie 5 L10 C As-Bult (2 ft Contow) 18

Figute 6 Cross Section Map 19

Figuie 7 10C Disposal Site Closute Covet 30

\section{List of Tables}

Tabie 6 I Radrological Volumetic Limuts for NTS Landfill Disposal 


\section{List of Acronyms}

\begin{tabular}{|ll}
$\mid$ ACM & Asbestos-Containing Material \\
ACWM & Asbestos-Containing Waste Material \\
CCRFD & Clark County Regional Flood Control District \\
CFR & Code of Federal Regulations \\
| CWMA & Controlled Waste Management Areas \\
DOE & U.S. Department of Energy \\
EPA & U.S. Environmental Protection Agcncy \\
FEMA & Federal Emergency Management Agency \\
| FFACO & Federal Facilities Agreement and Consent Order \\
NAC & Nevada Administrative Code \\
NDEP/BFF & Nevada Division of Environmental Protection, Bureau of Federal Facilities \\
| NNSA/NSO & National Nuclear Security Administration Nevada Site Office \\
NSTec & National Security Technologios LLC \\
NTS & Nevada Test Site \\
PCB & Polychlorinated Biphenyl \\
| RACM & Regulated Asbestos-Containing Material \\
RCRA & Resource Conservation and Recovery Act \\
| SAP & Sampling and Analysis Plan \\
SWDS & Solid Waste Disposal Site \\
SWMA & Solid Waste Management Authority \\
TSCA & Toxic Substance Control Act \\
I USGS & U.S. Geological Survey \\
WAC & Waste Acceptance Criteria \\
WW & Waste and Water
\end{tabular}


1.0 Applicant Information

Land Manager: $\quad$ U.S. National Nuclear Security Administration

(Owher) Department of Energy

Nevada Site Office

P.O. Box 98518

Las Vegas, NV 89193-8518

Authorized Agent: Ken M. Small

Program Manager, Resource Conservation and Recovery Act

Operator: National Security Technologies, LLC

P. O. Box 98521

Las Vegas, Nevada 89193-8521

Authorized Agent: Stephen M. Younger

President and General Manager

\subsection{Facility Information}

Name:

County:

Location:

NSO Coordinates:
Ul0C Solid Waste Disposal Site

Nye County

Nevada Test Site Area 9

$266395 \mathrm{~N}-206715 \mathrm{E}$ (meters)

(Based on Nevada State Plane Grid - Central Zone, North

Anerican Daturn, 1983)

\subsection{Policy}

Nevada Test Site (NTS) solid waste disposal sites must be permitted by the state of Nevada Solid Waste Management Authority (SWMA). The SWMA for tite NTS is the Nevada Division of Environmental Protection Bureau of Federal Facilities (NDEP/BFF). The U. S. Department of Energy (DOF) National Nuclear Secutity Administration Nevada Site Office (NNSANSO), as land manager (owner), and National Security Technologies (NSTec), as operator, will store, collect, process, and dispose of all solid waste by means that do not create a health hazard, public nuisance, or cause impairment of the environment. NTS disposal sites will not be included in the Nye County Solid Waste Management Plan. 


\subsection{Notification}

Portions of this document require signatory verification by a professional engineer or a qualified groundwater scientist approved by the state of Nevada. The internal process of creating and reviewing this document by NSTec and NNSA/NSO guarantees that qualified individuals have reviewed this document and concur with its content.

Nevada Administrative Code (NAC) 444.685 exempts entities of the federal government from the financial assurance requirements outlined in the state of Nevada solid waste disposal regulations. Therefore, these requirements are not addressed in this document. This document will function as part of the operating record for the disposal site described herein.

\subsection{Background Summary}

The NTS is located approximately $105 \mathrm{~km}$ (65 mi) northwest of Las Vegas, Nevada. NNSANSO is the federal lands management authority for the NTS and NSTec is the Management \& Operations contractor. Access on and off the NTS is tightly controlled, restricted, and guarded on a 24-hour basis. The NTS is posted with signs along its entire perimeter.

NSTec is the operator of all solid waste disposal sites on the NTS. The UlOC Disposal Site is located in the northwesl comer of Area 9 at the NTS (Figure 1) and is bocated in a subsidence crater created by two underground nuclear events, one in October 1962 and another in April 1964. The disposal site opened in 1971 for the disposal of rubbish, refuse, pathological waste, asbestos-containing material, and industrial solid waste. A Notice of Intent form to operate the disposal site as a Class If site was submitted to the state of Nevada on January 26, 1994, and was acknowledged in a letter to the DOE on February 8, 1994. It operated as a state of Nevada Class II Soljd Waste Disposal Site (SWDS) until it closed on October 5, 1995, for retrofit as a Class III SWDS. The retrofit consisted of the installation of a minimum four-foot compacted soil layer to scgregate the different waste types and function as a liner to inhibit leachate and water flow into the lower waste zone. Five neutron monitoring tubes were installed in this layer to monitor possible leachate production and water activity. Upon acceptance of the installed barrier and approval of an Operating Plan by NDEP/BFF, the site reopened in January 1996 as a Class IIl SWDS for the disposal of industrial solid wasle and other iner waste. 


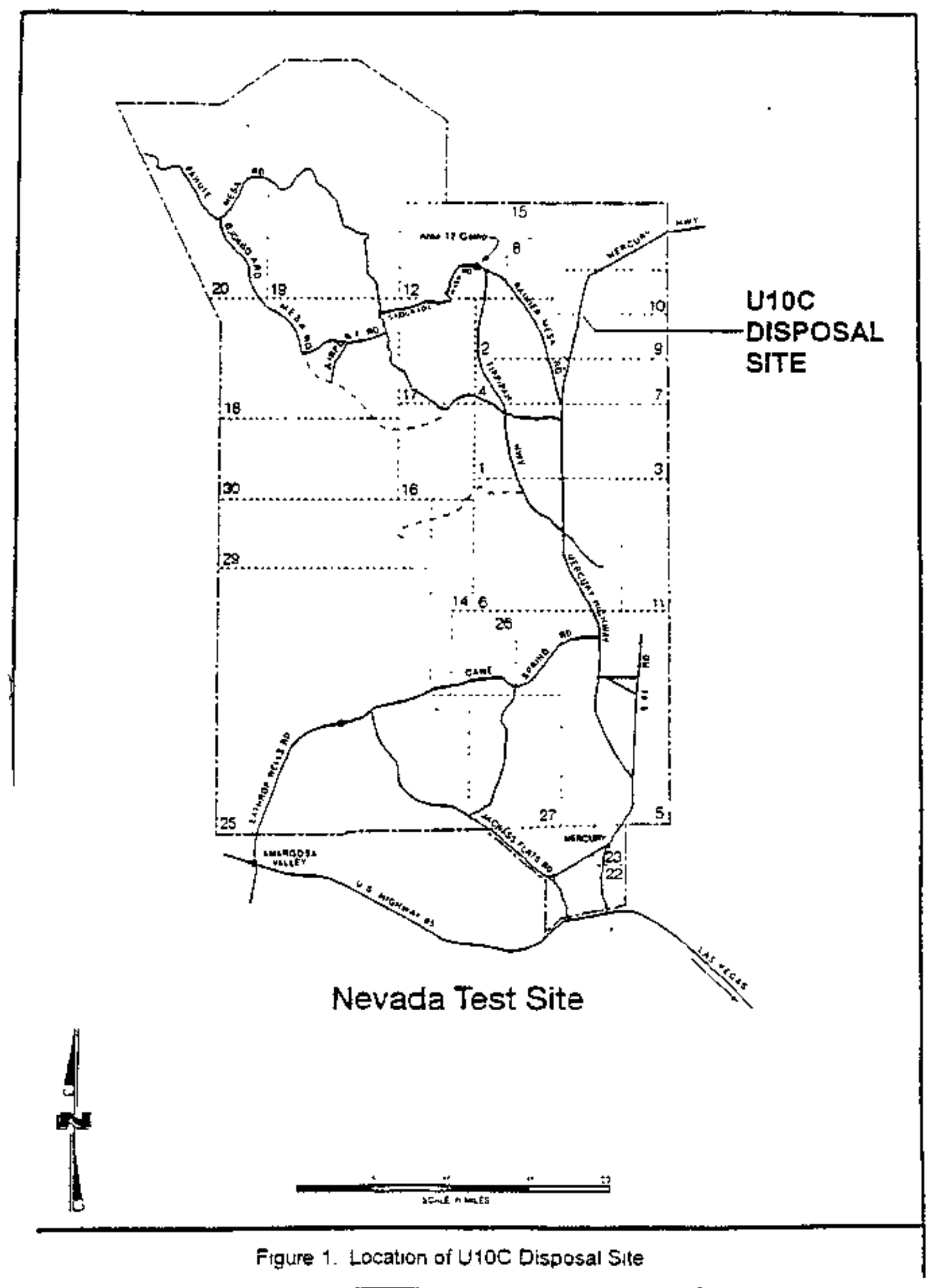




\subsection{Waste Characterization Plan}

\subsection{Summary}

The site will be used for the disposal of refuse, nubbish, garbage, sewage slodge, pathological waste, Asbestos-Containing Material (ACM), industrial solid waste, hydrocarbon-burdened soil, hydrocarbon-burdened demolition and construction waste, and other inert waste (hereafter called permissible waste). Waste containing free liquids or regulated under Subtitle $\mathrm{C}$ of the Resource Conscryation and Recovery Act (RCRA) will not be accepted for disposal at the site. Waste regulated under the Toxic Substance Control Act (TSCA), excluding Polychlorinated Biphenyl [PCB], Bulk Product Waste (see Section 6.2.5) and ACM (see Section 6.2.2.2) will not be accepted for disposal at the site.

The disposal site will be used as the sole depository of permissible waste which is:

- Generated by entities covered under the U.S. Environmental Protection Agency (EPA) Hazardous Waste Generator Identification Nomber for the NTS;

- Generated al sites identified in the Federal Facilities Agreement and Consent Order (FFACO);

- Sensitjve records and media, including documents, vugraphs, computer disks, typewriter ribbons, magnetic tapes, etc., generated by NNSA/NSO or its contractors;

- ACM generated by NNSA/NSO or its contractors according to Section 6.2.2.2, as necessary;

- Hydrocarbon-burdened soil and solid waste from areas covered under the EPA Hazardous Waste Generator Identification Number for the NTS;

- Other waste on a case-by-case concurrence by NDEP/BFF.

The generator of permissible waste is responsibie for preparing documentation related to waste acceptance criteria, waste characterization, and load verification. Waste and Water (WW) personnel are responsib]e for operating the disposal site and teviewing documentation to determine if the waste is acceptable.

\subsection{Waste Acceptance Criteria}

\subsubsection{Waste Characteristics}

Permissible waste shall be consistent with the following examples:

- Refuse consisting of jutrescible animal and vegetable wastes, primarily from food service operations;

- Rubbish consisting of combustible and non-combustible waste from office, industrial, and food service operations;

- Pathological waste consisting of dead aninal remains and dried sewage sludge;

- Non-regulated asbestos;

- Asphalt;

- Non-asbestiform insulation; 
- Metal sheet, bars, rods, tubes, and castings;

- Wood;

- Rubber (not including recyclable waste tires);

- Plaslic;

- Cloth;

- Paper;

- Cenent and concrele;

- Various materiats of geologic origin;

- Cable and wite;

- Empty containers;

- Manufactured items such as swamp coolers, fumiture, rugs, carpet, electronic components, etc.;

- Construction debris;

- Demolition debris;

- Drained fuel filters (gasoline and diesel);

- Crusheí non-terne plated oil filters;

- Solid factions from sand/oil/water separators;

- Decontaminated underground or aboveground storage tanks;

- Non-friable asbestos contained in buildings, housing structures, and trailers; and

- PCB bulk product waste.

Permissible waste may contain the following types of petroleum hydrocarbons or coolants:

- Various types of jet fuel;

- Various grades of diesel fuel;

- Hydrocarbon lubricants and hydraulics;

- Mineral oil;

- Kerosene;

- Asphaltic petroleum hydrocarbon; and

- Ethylene glycol.

The disposal of hydrocarbon-burdened soil and hydrocarbon-burdened demolition and construction waste will be limited to only one truck load per day, not to exceed 50 cubic yards per week. Larger amounts will require approval from NDEP/BFF on a case-by-case basis.

\subsubsection{Special Wastes}

\subsubsection{Automobiles and Military Transport Vehicles}

Autonobiles and military transport vehicles will be accepted for disposal. They will not be compacted but will have all fluids (fuel, crankcase oil, differential oil, power steering fluid, and radiator anti-freeze), tires, and batteries removed before disposal. Areas of the vehicles contaminated with residual fluids will not be characterized to determine the extent of hydrocarbon contamination or potential RCRA/TSCA constituents, unless knowledge indicates 
that these analyses are required. To allow cover material to fill as much void space as possible, doors and hoods will be removed before covering with soil.

\subsubsection{Regulated Asbestos-Containing Material (RACM) \\ RACM means:}

- Friable asbestos material;

- Category I nonfriable ACM that has bocome friable;

- Category I nonfriable ACM that will be or has been subjected to sanding, grinding, cutting, or abrading; or

- Category II nonfriable ACM that has a high probability of becoming or has become crumbled, pulverized, or reduced to powder by the forces expected to act on the material in the course of demolition or renovation operations regulated by Title 40 Code of Federal Regulations (CFR) 61 Subpart M.

\subsection{Packaging and Shipment Requirements}

RACM will be wetted with a water and surfactant mixture and packaged in:

- A plastic bag which is not less than six mils thick and sealed so that it is airtight; or

- A combination of plastic bags which cqual at least six mils in thickness; or

- A container made of cardboard or metal which is lined with plastic.

Each package will bear a label that conforms to the requirements identified in NAC 444.971.

The vehicle used to transport RACM will be fully enciosed or be covered so as to prevent damage to the bags or containers and prevent the release of asbestos fibers.

Each waste shipment will be accompanied by a shipping document and toad verification documentation. After the RACM is disposed of in the landfill, NNSA/NSO will submit copies of the documentation to the state of Nevada.

\subsection{Shipment Inspection and Refusal}

WW personnel shall inspect each load to verify compliance with packaging and shipping requirements. The following examples are cause for refusal:

- Required paperwork not available or incomplete;

- RACM is not wetted;

- Packaging is not labeled;

- Labels do not bear the correct statement; or

- Packaging has been breached causing asbestọs fibers to be released.

These discrepancies will result in all or portions of the shipment being set aside until the jdentified issue is resolved and corrective action taken by the generator. This may include, but is not limited to, wetting and repackaging the RACM. 


\subsection{Disposal Procedure}

A separate area within the disposal site has been designated for the disposal of RACM and asbestos-containing waste material (ACWM). The following procedures will be used when handling and disposing of RACM:

- Each package or container will be handled in a manner that limits breakage;

- Vehicles that contained a package or container that leaked will be rinsed out; and

- RACM will be covered with at least $15 \mathrm{~cm}$ (6 in) of compacted material that does not contain asbestos within 24 hours after placement.

\subsubsection{Prohibited Wastes}

The following wastes are probibited from disposal at this site:

- Hazardous waste per NAC 444,580 - see Section 6.2.4;

- Waste regulated by TSCA - see Section 6.2.5;

- Pernissible waste which exceeds the criteria in Section 6.2.6;

- Waste containing "free liquid" per NAC 444.692 - see Section 6.2.7;

- Waste tires - see Section 6.2.8;

- Medical waste per NAC 444.589;

\subsubsection{RCRA Constituents}

Permissible waste will not be accepted for disposal if it is determined that the material is a RCRA listed constituent or displays a RCRA characteristic. Material or environmental media contaminated with gasoline must be tested using the RCRA Toxicity Characteristic Leaching Procedure fot benzene and lead, as a minimum, unless process knowledge indicates the absence of these analytes. Fuel and oil filters are exempt from testing requirements after they have been drained of all liquid.

\subsubsection{TSCA Constituents}

Permissible waste must be tested for PCBs, unless process knowledge indicates their absence. The total concentration of PCBs must be below 50 parts per million (ppm) to be accepted for disposal. Infrequent disposal of fluorescent light batlasts, which may contain small amounts of PCBs, is not prohibited.

PCB bulk product wastes specifically identified in 40 CFR 761.62(b)(1)(i) (i.e., plastics, molded rubber parts, caulking, applied dried paint, vamishes, non-jiquid building demolition debris) and which meets waste acceptance criteria are to be disposed as permissible wastes regardless of PCB concentration. Further, NDEP requires that PCB bulk product waste disposal approval be handled on a case-by-case basis. 


\subsubsection{Radioactive Constituents}

Permissible waste submitted for disposal musl meet the surface activity release requirements in Article 422 of the NSOIORD Radiological Control Manual (May 2000), "Release to Uncontrolled Areas," and not exceed the mass concentrations in 10 CFR 30.70, Schedule A, or Table 6.I of this document. When radionuclides not identified in this section are known or suspected to be present in permissible wastes, applicable limits will be established before waste is accepted for disposal. All linits established for radionuclides not addressed in this section will be done with the concursence of the state of Nevada.

Table 6.1. Radiological Volumetric Limits for NTS Landfił Disposal

\begin{tabular}{|c|c|}
\hline Radionuclide* & $\begin{array}{l}\text { Mass Concentration Limits } \\
\text { (pCi/g) }\end{array}$ \\
\hline 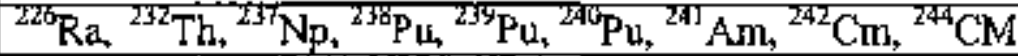 & 10 \\
\hline 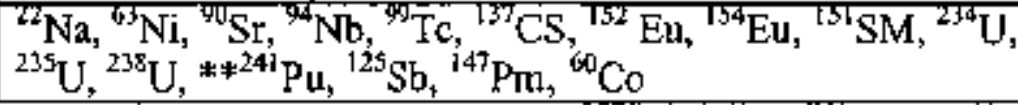 & 100 \\
\hline
\end{tabular}

* Progeny in equilibrium with their parent radionuclide have been incorporated with these limits (e.g., $137 \mathrm{Cs}, 90 \mathrm{Sr}$ ) and do not need a sum of fractions determination.

${ }^{* * 241} \mathrm{Pu}$ is an activation product, not a fission product. ${ }^{226} \mathrm{Ra}$ is a daughter product of ${ }^{238} \mathrm{U}$.

Based upon process knowledge, permissible waste generated outside Controlled Areas, as defined in the NSO/ORD Radiological Control Manual (May 2000), is assumed to have no added radioactivity and does not require surface contamination surveys or radiological analysis. Pemissible waste generaled inside Controlled Areas shall be segregated using one or more of the foljowing: process knowledge, surface surveys, or radiological analysis.

When a mixture of radionuchides is known or potentially present, a sum of fractions must be perfomed using the following equation:

$$
\sum_{i=1}^{n} \frac{C_{i}}{V L_{i}} \leq 1
$$

where $\mathrm{C}_{1}$ is the measured activity of radionuclide $\mathrm{i}$; $\mathrm{VE}_{1}$ is the mass concentration limit for radionuclide $\mathrm{i}$; and $\mathrm{n}$ is the number of radionuclides in the mixture.

\subsubsection{Free liquids}

Waste shall not contain free liquids. If testing is required to verify the absence of free liquid, it shall be performed by Test Method 9095: Paint Liquids Filter Test, described in "Test Methods for Evaluating Solid Wastes, Physical/Chemical Methods," EPA Publication Number SW-846. Sufficient sorbing material will be mixed with the permissible waste to ensure that free liquids do not exist before being accepted at the disposal site. The sorbing material will have similar 
physical and chemical properties to dry, fine grained soil or meet the criteria cstablished for nonbiodegradable sorbing materials found in 40 CFR 264.314, "Special requirements for bulk and containerized liquids." Coarse materials, which have popr sorbing characteristics and which may induce greater porosity in the compacted lifts, will not be used. Disposal site persontel shall inspect loads to verify the absence of free liquids. If free liquids are observed, the waste will be rejected.

\subsubsection{Waste Tires}

Recyclable waste tires are transported offsite to a Facility for the Management of Waste Tires. Tires that are unsuitable for recycling are disposed of in the Area 9 SWDS according to NAC 444.648.

\subsection{Waste Characterization}

Waste witl be characterized to ensilte that it meets acceptance criteria and will not create an environmental hazard or threaten the health of the general public. Waste will be characterized through process knowledge, sanpling, and analysis, or a combination of these methods.

\subsubsection{Process Knowledge}

Generators can adequately characterize permissible waste by their familiarity and experience with the process by which the material was generated. Process knowledge relies on a waste generalor's knowledge of the chemical properties of process ingredients, including concentration levels of contaminants in the ingredients at the start of the process; and how each step of the process chemically and/or physically affected the processed material by adding, removing, producing, depleting or neutralizing the contaminants in process ingredients, by-products, and/or finished products. Material Safety Data Sheets often are used as a means of identifying the process ingredients, and through the generator's knowledge of the process, the waste can be identified.

Process knowledge may also be "derived" through the repeated analyses of the same event. From repeated sampling and analyses, waste may be disposed of without further analysis.

Each generator using process knowledge will provide written documentation to the disposal site operator before disposal.

\subsubsection{Samnding and Analvsis}

A sampling and analysis plan for all suspect permissible waste will be developed and implemented. The plan ensures that each waste can be properly characterized for RCRA analytes, PCBs, or free liquids.

\subsubsection{Waste Minimization/Segregation}

It is NNSA/NSO policy to use waste minimization techniques to reduce waste generation. 'This may be accomplished by separating waste at the point of generation or collection. 


\subsection{Design Report}

\subsection{Design Information}

\subsubsection{Location and Facilities}

The disposal site is located at the north end of Yucea Flat in Area 9, NTS, Nye County, Nevada (see Figure 1). The site is Jocated in a subsidence crater which was created from two underground nuclear events. The first event, U10f (also known as Santee) was detonated on October 27, 1962. The second event, U10c (also known as Tufn), was detonated on April 24, 1964. The emplacement hole for Tuff is located $170 \mathrm{~m}$ ( $559 \mathrm{ft}$ ) northwest of Santee. The site opened in 1971 for the permanent disposal of nubish, refuse, pathological waste, asbestos-containing material, and industrial solid waste generated in the northern areas of the NTS. It operated as a state of Nevada Class II SDWS until it closed on October 5, 1995, for retrofit as a Class WI SDWS for the disposal of industrial solid waste and other inert waste.

Figure 2 is a topographic location map indicating all features within a $0.8 \mathrm{~km}(0.5 \mathrm{mi})$ area using a contour interval of $0.7 \mathrm{~m}(2 \mathrm{ft})$. Rather than using the NAC 444.680 regulatory requirement of a $1.6 \mathrm{~km}(1.0 \mathrm{mi})$ radius, a $0.8 \mathrm{~km}(0.5 \mathrm{mi})$ radius was chosen 10 obtain better tesolution of the site and its facilities. No other structures or changes in land use are located within a one mile radius.

Figure 3 enlarges the area surrounding the disposal site to identify the location of the bonow pit, fencing, site facilities, and the location of the monitoring tubes. Figure 4 represents the expanded borrow pit (approvod by NDEP/BFF May 10, 2000). The closest inhabited strueture, a trailer, is located at the entrance to the site. The facility will be staffed when in operation. Figure 5 is an As-Built drawing of the site with a typical cross section A identified. The typical cross section is shown in Figure 6.

Vehicles travel to the disposal site via permanent, paved roads constructed on the NTS.

A roadway leading directly into the disposal site off the main road is approximately one-quarter mile long and consists of tightly compacted soil and gravel. A compacted ditt road winds down to the bottom of the disposal site.

Access to the interior of the site is controlled by a perimeter fence which has a locked gate to prevent unauthorized disposal of solid waste. The entrance to the disposal site is posted with a sign that clearly indicates the operator of the disposal site, the hours of operation, and wastes that are accepted for disposal. Site facilities consist of a base station (trailer) with electrical power, radio communication system, telephone, portable toilets, potable water dispensers, and a truck scale.

\subsubsection{Liner Svstem}

A minimum $1.2 \mathrm{~m}$ (4 $\mathrm{a})$ compacted soil barrier was installed in late 1995 before opening the site for the disposal of permissible waste. A review of the construction project is provided in Appendix A. The purpose of the soil layer is to segregate the two different portions of the disposal site and inhibit leachate through the barrier, thus acting as a tiner for the permissible 
waste. As an indicator of the amount of water and hydrocarbon leachate entering into the soil barrier, five neutron monitoring tubes have been placed three feet into the layer. Initial neutron logging started on a monthly basis in Jamuary 1996. Annual teadings will be performed thereafter to determine if water or hydrocarbon leachate has entered this barrier.

\subsubsection{Methane Gas Monitoring}

Based on knowledge of the physical and chemical composition of the past and currently generated waste and low annual ratnfal attributing to high evapotranspiration at the disposal site, the generation and accumulation of explosive or toxic gases is considered minimal or non-existent. Therefore, gas monitoring is not considered necessary.

\subsubsection{Airport Safety}

The NTS has two landing strips and one aimort available for use. These facilities are greater than $3 \mathrm{~km}(10,000 \mathrm{ft})$ from the disposal site and not available for public use. Therefore, they are not subject to state of Nevada municipal solid waste landfitl requirements.

\subsubsection{0-Year Flood Plain}

A hydrologic/hydrautic assessment of the area (Appendix B) was performed using methods described in the Clatk County Regional Flood Control District (CCRFCD) Manial (CCRFCD, 1990). The disposal site could be impacted by floods from the watershed (Appendix C) that covers approximately $7.7 \mathrm{~km}^{2}$ ( $3 \mathrm{mi}^{2}$ ) northwest of the site. Field investigations and caiculations indicate that a detention system comprised of both the natural topography west of Circle Road and the elevated road grade will provide approximately 63.7 ha-m ( $48 \mathrm{ac}-\mathrm{ft}$ ) of storage volume. Onc $0.6 \mathrm{~m}(2 \mathrm{ft})$ and one $1 \mathrm{~m}(3 \mathrm{ft})$ culvert will release water under the roadway from the detextion area.

A storage routing model, developed using the HEC-1 Flood Hydrograph Package (COE, 1990), indicates that storage volume for $46.5 \mathrm{ha}-\mathrm{m}$ ( $35 \mathrm{ac}-\mathrm{ft}$ ) of water is required and that simultaneous discharge from both culverts will result in a peak discharge of $1 \mathrm{M} 3 / \mathrm{Min}\left(37 \mathrm{ft}^{3} / \mathrm{sec}\right)$. Flow

released through the culverts will become sheetflow with peak discharge resulting in a maximum depth of $0.009 \mathrm{~m}(0.03 \mathrm{ft})$. This depth is less than the $0.3 \mathrm{~m}$ (1 ft) Federal Emergency Management Agency (FEMA) regulatory depth for a 100-year flood hazard zone (FEMA, 1991). Therefore, the disposal site is not within a 100-year flood hazard zone.

\subsubsection{Sarface Water Protection}

There are no perennial bodies of surface water in the vicinity or immediately downgradient from the disposal site which require protection from potential disposal site water runoff.

\subsubsection{Ground Stability}

The NTS is in the southern Great Basin region of the Basin and Range Physiographic Province. The PJovince is characterized by a series of north-south trending mountain ranges separated by broad alluvial valieys. The higher elevations on the NTS are on Pahute Mesa, approximately $2,200 \mathrm{~m}(7,216 \mathrm{ft})$ and Rainier Mesa, $2,340 \mathrm{~m}(7,675 \mathrm{ft})$ above sea level. The lowest elevations 
are in Frenchman Flat and Jackass Flat, both at approximately $910 \mathrm{~m}(3,000 \mathrm{ft})$ above sea level (ERIDA, 1977).

Yucca Flat is one of thee principal valieys withit the N`S. Yucca Flat is approximately $129 \mathrm{~km}$ (80 mi) northwest of Las Vegas. It is $31 \mathrm{~km}$ (19 mi) long and $16 \mathrm{~km}$ (10 mi) wide; elevations range from 900 to $1,400 \mathrm{~m}(3,000$ to $4,600 \mathrm{ft})$ above sea level (DRI, 1988). The disposal site is in the north portion of Yucca Fla! at an elevation of $1,298 \mathrm{~m}(4,261 \mathrm{ft})$ above sea level.

Three major rock units predominate at the NTS: complexly folded and faulted sedimentary nocks of the Paleozoic age, volcanic tuffs and lavas of the Tertiary age, and alluvium of late Tertiary and Quaternary age. In many places, Paleozoic sediments are overlain by volcanic tuffs and lavas. The alluvium was derived from erosion of the nearby hills composed of Tertiary and Paleozoic rocks (ERIDA, 1977).

A U.S. Geological Survey (USGS) study (Williams, 1965) provided information on the lithology of the immediate area. The $588 \mathrm{~m}(1,930 \mathrm{ft})$ lithologic log of drill hole U10C indicates that Quatemary and Tertiary alluvium exists from ground level down to approximately $479 \mathrm{~m}$ $(1,570 \mathrm{ft})$. The makeup of this material is tuffaceous sand and gravel in varied proportions. The upper $122 \mathrm{~m}$ (400 ft) consists primarily of quartzite fragments, while the lower portion is predominately zeolite, quartz, and feldspar. Tertiary Timber Mountain Tuff exists bejow this level. The makeup of the tuff layer is primarily quartz and sanidine crystals with a $12 \mathrm{~m}$ ( $40 \mathrm{f}$ ) layer of principally black vitrophyre at the $536 \mathrm{~m}(1,760 \mathrm{ft})$ to $626 \mathrm{~m}(1,800 \mathrm{ft})$ depth.

Soil testing was performed at the site in September 1994 (Appendix D). Four samples were obtained at corners around the disposal site. Test laboratory data indicates that the near surface soils primarily consist of fine; silty sand with a permeability averaging about $2.2 \times 10-5 \mathrm{~cm} / \mathrm{sec}$. These soil characteristics are consistent with characteristics of the sutrounding native alluvium as described by Williams (1965).

Williams (1965) described surface effects from the U10C undergtound test, Paved roads in the area were not damaged; however, moderate surface fractures developed in the alluvium from the 20 to 150 kiloton nuclear blast. Local compaction of the alluvium occurred in the immediate area of ground zero. Some ground cracking and vertical displacement of the Yucea Fault resulted from the blast. Given the intensity of the blast, ground stability was estabjisher which indicales that soil in the area is not susceptible to mass movement from a natural or man-made event.

\subsection{Types, Ouantities, and Sources of Waste}

The disposal site will be used as the sole depository of permissible waste which has ben identified in the Waste Characterization Plan (see Section 6.0). These wastes and environmental media will be:

- Generated by entities covered under the EPA Hazardous Waste Generator Identification Number for the NTS;

- Generated at sites identified in the FFACO;

- Sensitive records and media, including documents, vugraphs, computer disks, typewriter ribbons, magnetic tapes, etc, generated by NNSA/NSO or its contractors; 
- ACM generated by NNSANSO or its contractors according to Section 6.2.3.2, as nccessary;

- Hydrocarbon-burdened soil and solid waste from areas covered under the EPA Hazardous Waste Generator Identification Number for: the NTS;

- Other waste on a case-by-case concurrence by NDEP/BFF.

Records indicate that the subsidence crater volume after the detonation of the Tuff event was approximately 1.6 million $\mathrm{m}^{3}\left(2.1\right.$ million $\mathrm{yd}^{3}$ ) (Williams, 1965). From the time the site opened in 1971 until the barrier layer was installed in 1995, approxinately 0.84 million $\mathrm{m}$

( 1.10 million yd) of waste and cover material were added to the disposal site. Construction of the barrier layer incorporated another $91,760 \mathrm{~m}^{3}\left(120,000 \mathrm{yd}^{3}\right)$ of volume, leaving approximately $676,000 \mathrm{~m}\left(885,000 \mathrm{yd}^{3}\right)$ of Jandfill capacity currently available for use. Assuming the continued use of space at the same rate, a constant waste weight, and consistent use of cover material, approximately 169,000 metric tons (221,000 tons) of waste will be disposed of during the remaining site's useful lifetime. At the current rate of disposal since the site reopened in Jantary 1996, it is estimated that the lifetime of the site is approximately 63 years. A volume study performed in December 2008 estimated that the lifetime of the site is approximately 16 years with an estimated sernaining volume of 539,833 cubic yards.

\section{$7,3 \quad$ Hvdrogeologic Characteristics}

Groundwater flowing beneath the Yucca Flat area passes through rocks that differ substantially in terms of age, composition, and waler-beating properties. In general, the hydrogeologic units under the disposal site consist of unsaturated and saturated portions of the valley-fill aquifer that overlies a series of tuff volcanic aquifer and conîning units, which in turn overiie the upper clastic confining unit and regional lower carbonate aquifer. The volcanic and carbonate rocks dip westward beneath Yucca Flat and are bounded on the west by the Topgaliant fault.

Four major areas of groundwater discharge occur down gradicnt of the NTS, including the Oasis Valley and Ash Meadows discharge areas in Nevada and the Alkali Flat and Death Valtey discharge areas in California (Winograd and Thordarson, 1975). The Yucea Flat area is encompassed by the Ash Meadows subbasin. The lower carbonatc aquifer is the principal aquifer in the Ash Meadow subbasin, while the valley-fill and volcanic aquifers are locally important in the Yucca Flat area. Groundwater from the Ash Meadows subbasin discharges to the surface at Ash Meadows from a line of springs about $16 \mathrm{~km}$ (10 mi) long. This spring line is located about $64 \mathrm{~km}$ ( $40 \mathrm{mi}$ ) down gradient of Yucca Flat (Winograd and Thordarson, 1975). The rale of groundwater flow through the subbasin is highly variable and estimates vary over orders of magnitude, ranging from less than $0.01 \mathrm{ft} /$ day to more than $100 \mathrm{ft} /$ day for the different hydrogeologic units along various flow paths (O'Neill et al, 1993).

Groundwater is withdrawn from wells located throughout the subbasin for potable and

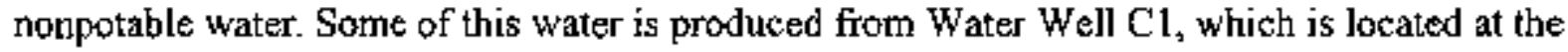
southern edge of Yucca Flat. The depth to ground water is approximately $457 \mathrm{~m}$ (1,550 ft) below the land surface. This well is located approximately $26 \mathrm{~km}(16 \mathrm{mi})$ south of the site. Studies at $\mathrm{U} 10 \mathrm{C}$ and adjoining blast sites indicate that groundwater is approximately 553 to $567 \mathrm{~m}$ $(\mathrm{L}, 815$ to $1,860 \mathrm{ft})$ below ground level in the immediate area. 


\subsection{Climate}

The climate of the NTS is typical of a high desert basin, exhibiting low precipitation and low relative humidity. Annual precipitation in the Yucca Flat basin is generally less than $15 \mathrm{~cm}(6 \mathrm{in})$ with the majority of the annual average occurring during the winter months. (Anntal rainfall in 1995 at a site approximately $7.5 \mathrm{~km}[4.7 \mathrm{mi}]$ south of the site was $18 \mathrm{~mm}[0.72 \mathrm{in}]$.$) Typical$ temperatures range from -7 to $10 \mathrm{C}(20$ to $50 \mathrm{~F})$ during the winter and 16 to $38 \mathrm{C}(60$ to $100 \mathrm{~F})$ during the summer (RSN, 1994), Wind patterns at the NTS are influenced by the movement of major air-pressure systems, movements due to regional topography, and localized effects due to terrain (Quiring, 1968). Southerly winds predominate in the summer and northerly winds are more common in the winter. The wind direction also varies with the time of day, with southerly winds occurring during the day and nottherly winds at night (ERDA, 1977). Wind speeds at the NTS are generally strong in the spring, with averages of $9 \mathrm{~m} / \mathrm{sec}(20 \mathrm{mi} / \mathrm{hr})$ during spring aftemoons, and mild in the fall. Gusts may occur throughout the year, usually in conjunction with late summer thunderstorms.

\subsection{Runon and Runoff Control}

The hydrologic/hydraulic assessment, previously described in Section 7.1.5, was performed using a 100-year 6-hour flood event, which exceeds the requirements for numon protection from a 25 -year flood event. The assessinent indicates that the 100 -year, 6 -hour flood requires storage volume for $46.5 \mathrm{ha}-\mathrm{m}$ ( 35 -ac-ft) of water. Therefore, the natural detention system, with a storage volume of 63.8 ha-m (48 acre-ft), provides sufficient storage for this event. Also, according to the CCRFCD Manual ( 1990 ), the basin will completely drain in less than 24 hours (see Appendix B).

Flow released from the detention area will become sheetflow. Existing topography will provide adequate sheetflow protection for the disposal site. The majority of the sheetflow will come from north-northwest of the site. Flow will be intercepted by an existing channel along the north side of the sile, channelizing flow to the east. Sheetflow along the west side of the site will be intercepted by the bortow pit or wilt flow south-southeast past the disposal site.

The requirement for ranoff control has not been addressed due to the location, depth, and almost full berming of the disposal site. This issue will be addressed for further consideration when it has been determined through an internal assessment that there is a need for additional control. 


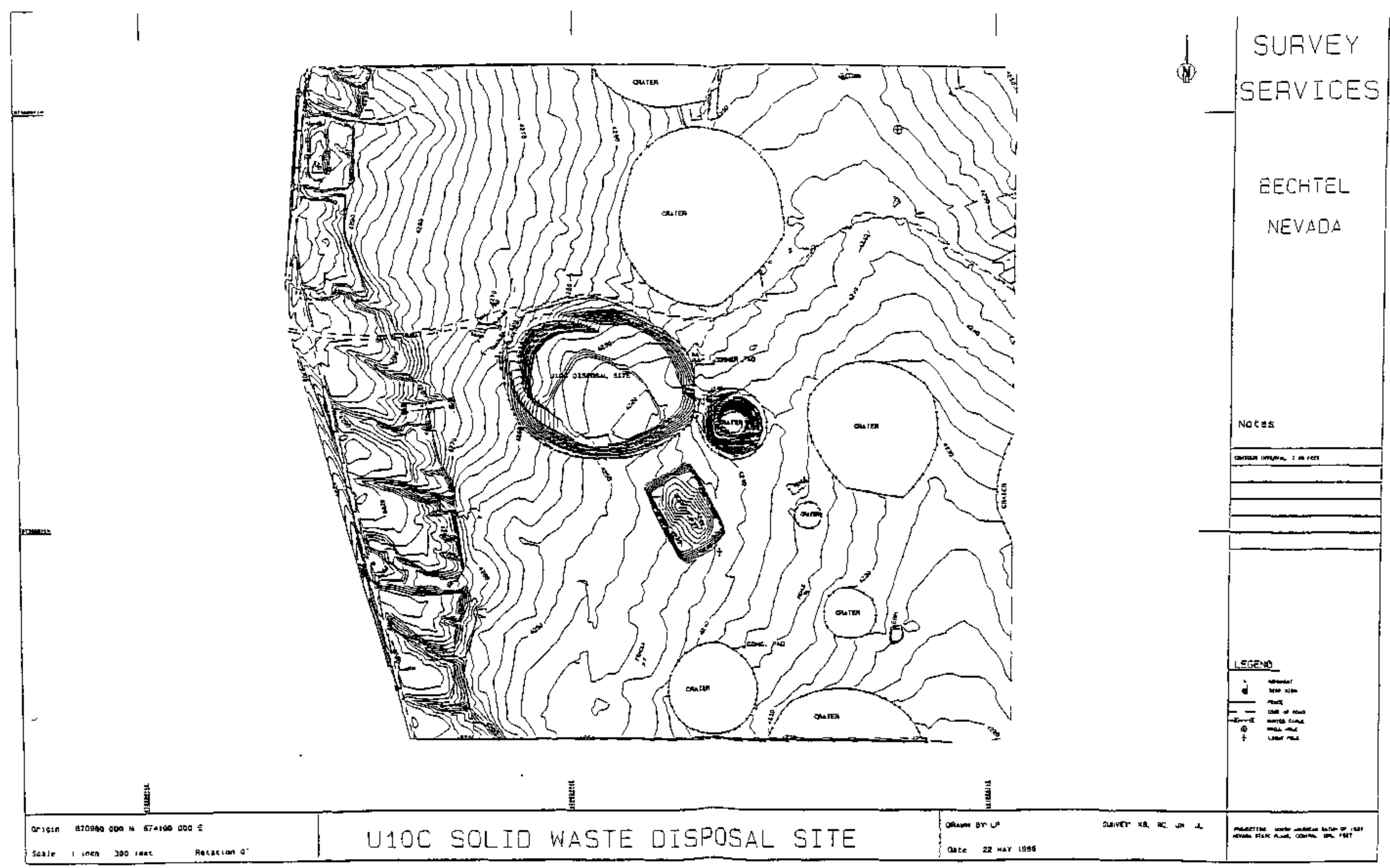

Figure 2. Disposal Site Map - 1/2 Mile Radius (2.0 ft contour) - May 1996 


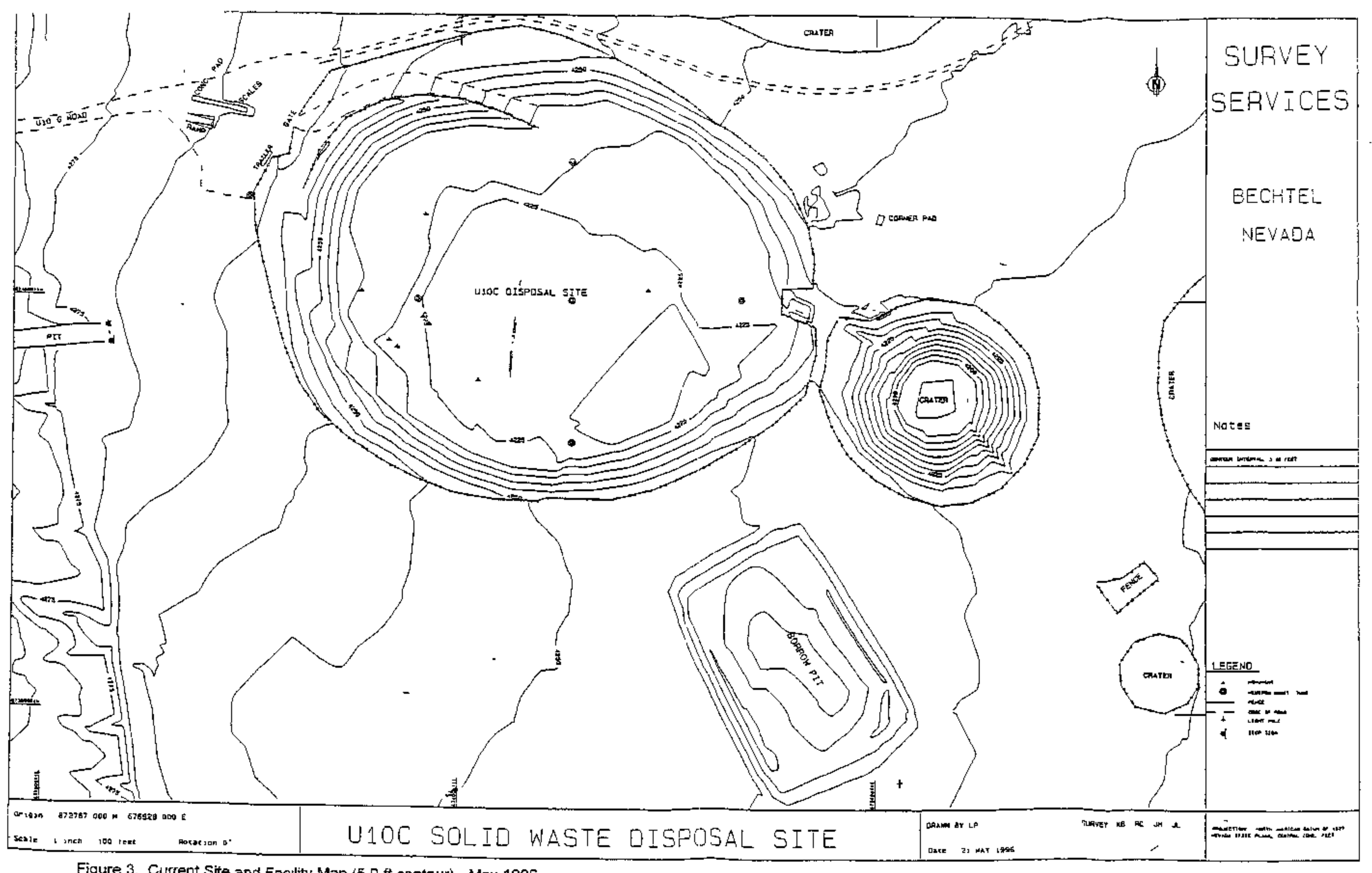

Figure 3. Current Site and Faclity Map (5.0 ft contour) - May 1996 


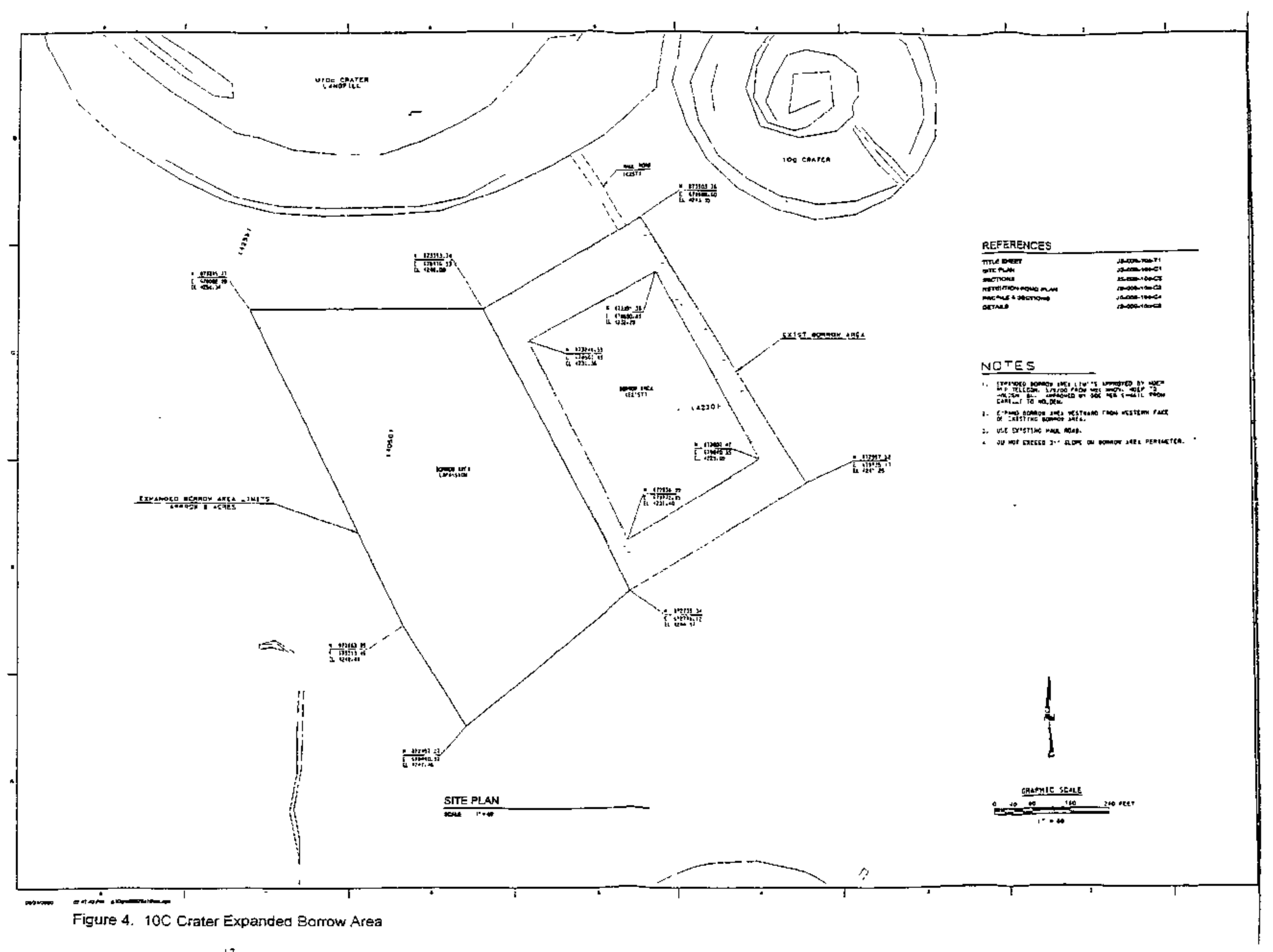




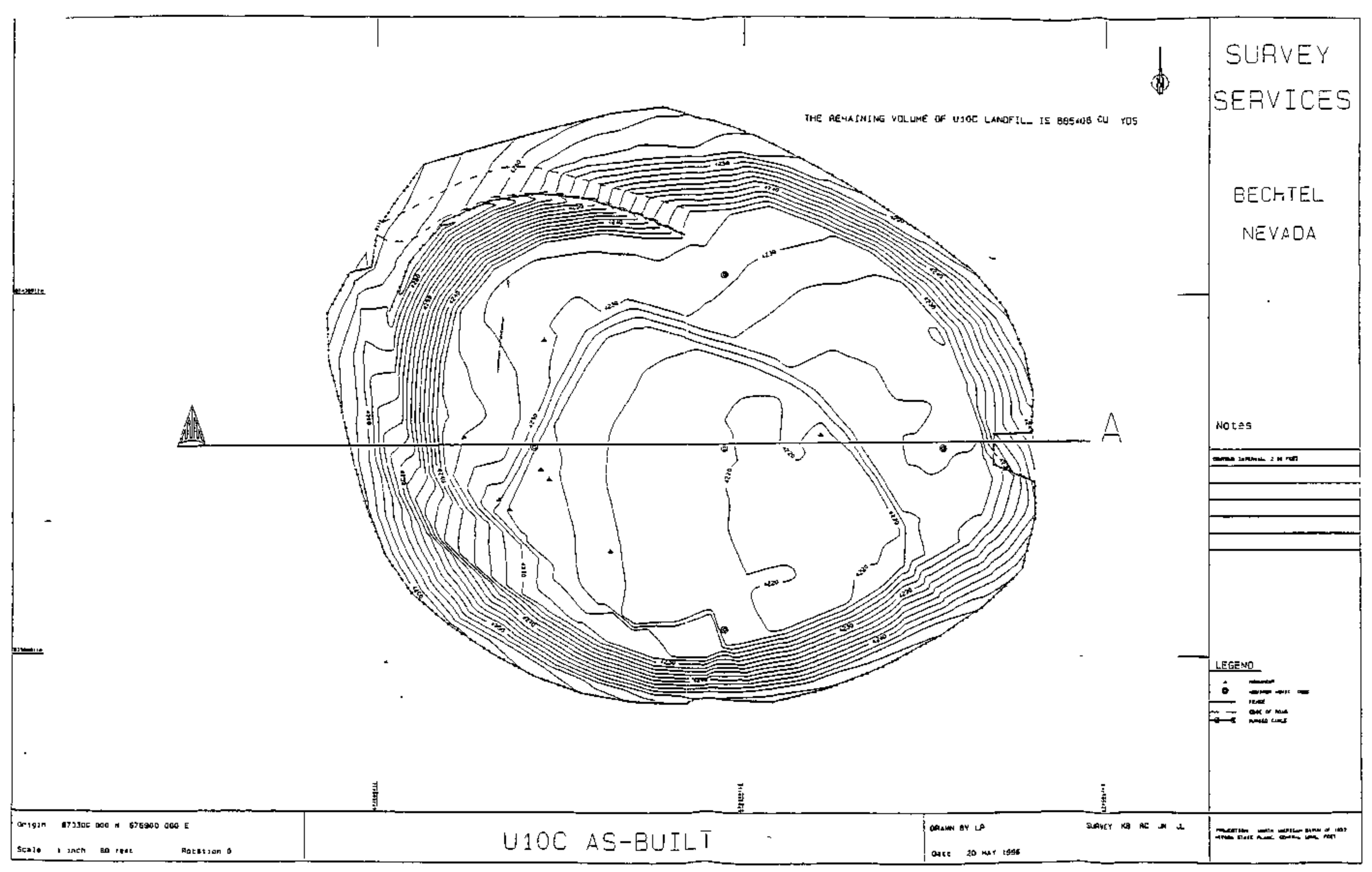

Figure 5 U10C As-Burt (2.0 ft contour) - May 1996 


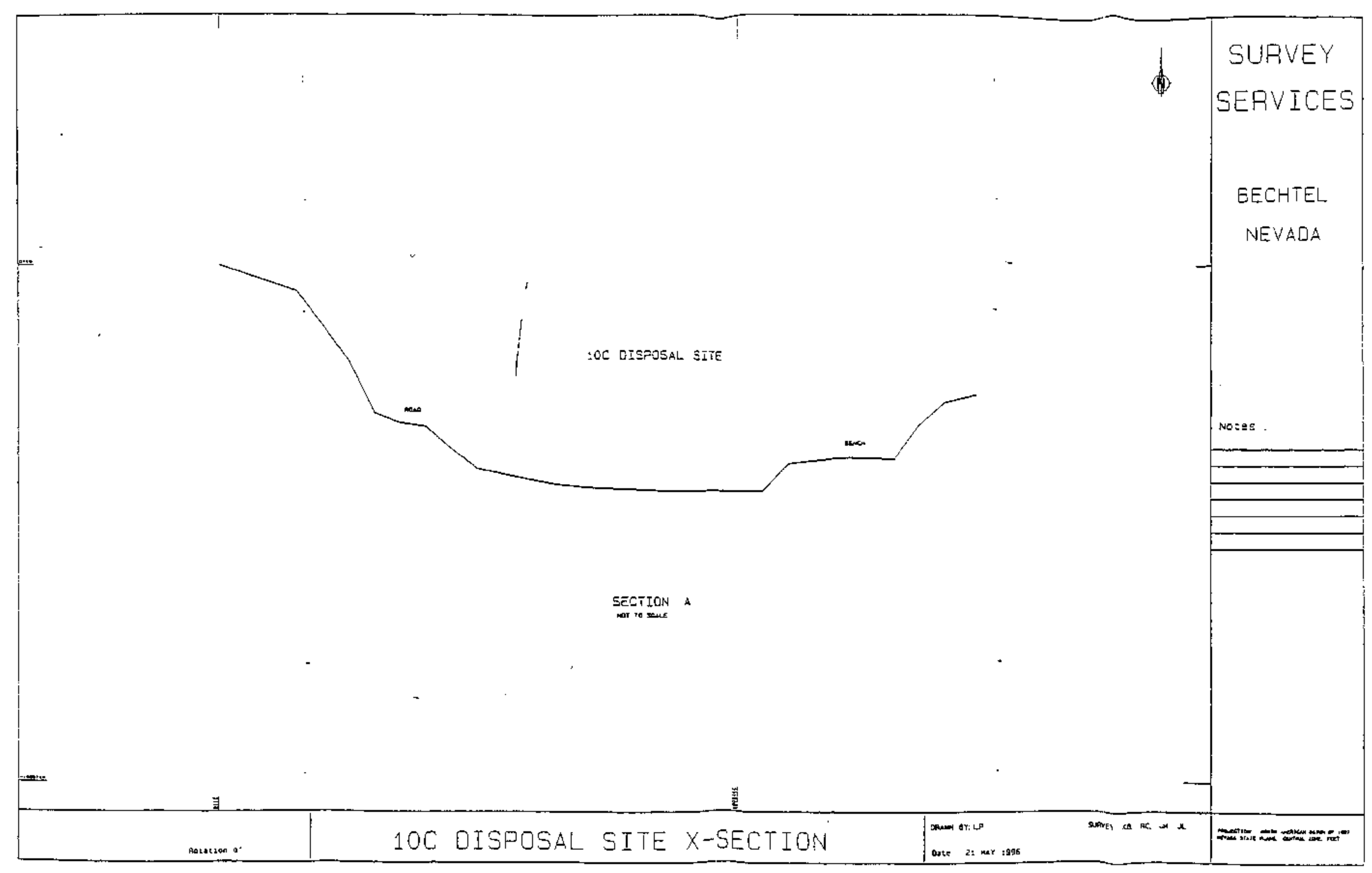

Figure $\theta$. Cross Section Map - May 1996 


\subsection{Water Monitoring Plan}

\subsection{Groundwater Monitoring Waiver}

The state of Nevada may suspend groundwater monitoring requirements if it can be demonstrated that "there is no potential for migration of pollutants and contaminants from the site to the waters of the state during the active life of the site, inchuding the period of closure and post closure" [NAC 444.683]. This demsonstration must be based on "processes affecting the fate and transport of contaminants and predictions of the fate and transportation of contaminants and a consideration, of the impacts on public health and the environment" [NAC 444.7481 ]. The major factors affecting leachate generation and migtation into the groundwater are climate, geology and hydrogeology, water availability, and the condition of the waste before and after placement into the disposal site. Each of these factors is discussed below.

\subsubsection{Climatic Factors}

The climatic conditions are discussed in detail in Section 7.4. In general, the average anmual precipitation is less than $15 \mathrm{~cm}$ ( 6 in) with the majority occurting during the winter months. This weather pattern is followed by mild ternperatures and windy conditions in the spring. Summer weather is hot and breezy with low humidity. There are isolated periods of stormy weather late in the season. The fall is usually baimy and variably windy.

These climatic factors are a great determining factor for a large water evaporation rate. An evaporation study was performed fiom February 1993 to September 1993 at a site approximately $14 \mathrm{~km}(9 \mathrm{mi})$ south of the disposal site (Frencl1, 19.93). Results of the study indicated that the annual precipitation for the area is $125 \mathrm{~mm}$ ( $5 \mathrm{in}$ ), and the estimated evaporation potential is $1,814 \mathrm{~mm}$ (71.4 in). One may therefore conclude that evaporation is a doninant factor influencing surface and upper vadose zone waters which will inhibit the potential for leachate generation and subsequent transport into the groundwater.

\subsubsection{Geologv/Hydrogeology Factors}

The geology/hydrogeology characteristics of the area are discussed in derail in Sections 7.1.7 and 7.3. In general, the surface soils consist predominantly of silty sand. Moisture profiles of similar soils monitored over time at the low-level radioactive waste site in Beatty indicate that water percolates and redistributes to depths of only $2 \mathrm{~m}(6.6 \mathrm{ft})$ below the surface after an intense rainfall (Nichols, 1987). Fischer (1992) found that water potential gradients between depths of 7 and $13 \mathrm{~m}$ (23 to $43 \mathrm{ft})$ acted in an upward direction.

As indicated in Section 7.3 , the depth to groundwater is over $549 \mathrm{~m}$ (1,800 ft). Although information on the working point depth of the L $10 \mathrm{C}$ event is classified, it is likely that this nuclear event and others in the area have compromised the quality of the groundwater under this disposal site. NNSA/NSO is currently studying the effects of nuclear blasts on ground water through its Underground Testing Atea Cortective Action Work Plan. Given these studies, geology/hydrogeology factors inhibit or prevent infiltrate or leachate from reaching the groundwater. 


\subsubsection{Water Availabillity}

Liquid must first be present in the landfill in order for leachate to be formed or migrate. The following site-specific characteristics inhibit leachafe formation and migration:

- A relatively small amount of rain impacts the site by direct onfall and climatic conditions are favorable for evaporation to exceed infiltration (see Sections 7.4 and 8.1.1).

- Waste Acceptance Criteria (WAC) prohibits the disposal of "free liquids" (see Section 6.2.7).

- Runon does not affect the disposal site (see Section 7.5).

The presence of these natural and man-made controls greatly inhibits the formation of significant amounts of leachate which could then migrate to the groundwater.

\subsubsection{Waste and Cover Conditions}

The condition of the waste and cover material are factors which inhibit the formation of leachate. The following factors are relcvant:

- "Free liquids" are prohibited in the disposal site (see Section 6.2.7).

- The barrier layer, which is a minimal $1.2 \mathrm{~m}$ ( $4 \mathrm{ft}$ ) layer of compacted native soil, possesses saturation and porosity factors which must be exceeded before leachate may migrate through the layer (see Section 7.1.2).

- Pernissible waste addied to the disposal site is not water saturated and sufficient unburdened soil is added as cover to assure that the total soil mass in the site is unsaturated. Due to the lack of moisture, there is no driving force for potential liquids to form leachate (see Sections 8.1.1 and 8.1.3).

Given these factors, the potential for leachate formation is considered minimal; however, a soil moisture monitoring system has been instal led to detect changes in the compacted soil barrier which forms the bottom liner.

\subsection{Monitoring System}

The soil moisture monitoring system consists of five vertical neutron access tubes within the disposal site margins and one monitoring tube outside the perimeter of the disposal site

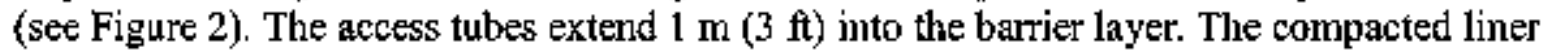
material at the bottom is necessary as a clean zone for background counts, as well as a buffer zone in the unlikely event of hydrocarbon or water transport.

Initial neutron logging took place in December 1995. Water added for dust control and compaction during construction have affected initial counts and accurate background counts will not be available until the system comes to equilibrium. Logging took place monthly during the first eight months of operation to establish a baseline. Thereafter, logging occurred 
semi-annually. However, Section 8.1 of the permit application states that the monitoring frequency may be reduced. The monitoring history of the Ul0c Landfill demonstrates stability of site moisture content. A review of the monitoring history demonstrated that the moisture content has been satisfactorily below regulatory action levels. As a result, NDEP/BFF agreed to lower the monitoring frequency for the U10C Landfill from semi-annually to annually.

Access tubes should be inspected with a minor for condensate before logging and any condensate should be swabbed out with absorbent material attached to a pole. The minimum logging interval is $0.3 \mathrm{~m}(1 \mathrm{ft}$ ).

The monitoring system is designed to detect liquid movement through the four-foot layer of compacled soil, as well as monitor changes in the industrial solid waste. Only changes within the four-foot layer of compacted soil will trigger a response to NDEP/BFF; changes within the waste will simply be monitored. Should the Action Level be reached, the NDEP/BFF will be advised and appropriate action will be determined in conjunction with NDEP/BFF.

Logging will continue annually throughout the active life of the disposal site. Continued use of the system will be addressed in the closure and post-closure plans for the site.

\subsubsection{Monitoring Tube Report}

A neutron soil moisture gauge will be used to monitor for changes in the soil moisture content within the 1.2-m (4-ft) interval. All data will be reported as either counts per minute or percent soil moisture content. The Action Level requiring NDEP/BFF notification will be the midpoint between the existing baseline data (representing dry conditions) and saturated conditions measured at a point approximately $0.3 \mathrm{~m}(1 \mathrm{ft})$ above the bottom of the monitoring tube. The NDEP/BFF will be notified of any Action Level reached or exceeded within 21 days of the confirmation.

A monitoring report will be sent annually to NDEP/BFF. Neutron logging of each monitoring tube will be performed in the first quarter of each calendar year: The report will be formatted into two parts:

- A short narrative discussing current results, identifiable trends, and identification of periods when free standing water is visible within the disposal area; and

- Graphical representation of rainfall and counts over time that will indicate trends.

The report will be sent to NDEP/BFF no later than the last Friday of the second quarter. 


\subsection{Operating Plan}

\subsection{Collection and Transportation}

WW personnel will be responsible for the operation and maintenance of the disposal site. Collection and transportation will be the responsibility of the facility manager or generator of the permissible waste.

\section{$9.2 \quad$ Personmel}

One disposal site operator and a teamster are regularly assigned to the disposal site to control access during hours of opcration, determine acceptance of the waste, and weigh the solid waste before the collection vehicle enters the disposal site. During abnormal circurnstances, additional personnel may be required. However, under no circumstances will the disposal site have less than two workers in attendanee during heavy equipment operation.

\section{$9.3 \quad$ Processing In}

Loads of waste may only be processed while WW personnel are working at the disposal site. Each load of industrial solid waste or special waste will be accompanied with the following paperwork:

- Signed load verification documentation which contains waste charactcrization information, a statement on the absence of prohibited materials, and the waste source by location;

- Radiological certification, if necessary; and

- Weight or wejght estimate.

A truck scale is available at the disposal site to determine the weight of the waste. However, disposal site operators may accept weight measurements from other scales. If the truck scale at the disposal site is not functioning or it is not practicable to weigh the waste due to its size or other physical characteristics, other adequate measures can be used to determine the weight of the waste. If the truck scale is not functioning, WW personnel will correct the deficiency. Scales used are electronic and are designed and manufactured to remain in calibration; an annual calibration check is conducted.

\subsection{Off-Logding}

Before entering the disposal site, transporters of industrial waste will be required to have a weigh ticket or estimated weight. Disposal site operators shall designate the area of the disposal site where the transporter will off-load. Industrial waste may be offloaded either by the transporter or disposal site personnel. Disposal site operators will ensure that bulky waste larger than two feet in any axis will be arranged horizontally across the base of the disposal site to achieve the thingest Jift possible. 


\subsection{Daity Log}

A daily log will be maintained to indicate the following:

- Each load of industrial solid waste which is disposed;

- Identification of personnel entering the disposal site;

- Routine disposal site activities such as operational/temporary cover installation, litter control, dust suppression, etc.; and

- Nonroutine events such as unforeseen circumstances (fire, medical, equipment failure, recyclable material retrieval, hazardous or toxic wastc identification), rainfall indicators, and those events which cause pooling water or erosion.

\subsection{Random Inspections}

WW personnel will inspect one randomly selected load of waste monthly. Once the waste has been dumped onto the ground, the inspector will closely examine the load of industrial solid waste or special waste to determine if prohibited materials, identified in Section 4.1 of this Plan, are contained in the waste. Each inspection will be documented, signed by the inspector, and placed in the disposal site operating record.

If prohibited waste is identified in the disposal site by site personnel or during randomly selected inspections, the area will be cordoned off and operations in the area will be discontinued. The area will not be reopened until an investigation of the circumstances responsible for the disposal of the hazardous or toxic waste are completed and documented. This procedure does not apply to recyclabic itcms that may be considered a hazardous waste (i.e., batteries, lead bricks, partially full aerosol cans). Recyclables must be segregated when discovered, documented in the daily $\log$, and turned over to WW supervision for proper disposal.

NDEP/BFF, through NNSA/NSO, will be notifted if prohibited wastes are discovered at the site either through random inspections or during daily operations. This notification will be made to WW supervision by the disposal site operator.

\subsection{Sjgnage/Llours of Operation}

A sign is posted at the entrance to the disposal site which informs personnel of the hours of operation, prohibited materials, and an emergency contact telephone number. The site is protected from entry by a locked chain between two guard posts at the entry and a fence completely surrounding the site (see Figure 6 for locations).

\subsection{Disposal Site Equipment}

Many types of vehicles may be used at the NTS to collect and transport solid waste. Collection vehicles may consist of 4-cubic yard load luggers, 20-cubic yard roll-off boxes, shor and long flat bed and dump bed trucks, pickup trucks, or trailers. 
The equipment used at the disposal site consists of a D-8 dozer, a 4- or 8-cubic yard front end loader, a non-potable water truck, and a motor grader. Other types of equipment that may be used at the disposal site on an irregular basis include cranes, forklifts, and rollers.

\section{$9.9 \quad$ Operating Records}

Records and a log will be maintained by designated disposal site personnel.

The following documentation must be present with each load of permissible waste, if applicable:

- A load verification document;

- Analytical results or written docurnentation of process knowledge;

- Weigh ticket or estimated weight; and

- Radioactive Material Clearance.

Before acceptance, the disposal site operator will ensure that all documentation is complete, accurate, and legible. If the documentation is not acceptable, the disposal site operator will reject the waste for disposal. The disposal operator may also reject the waste, if upon a random inspection, it is determined that the waste does not conform to WAC or is falsely represented.

The amount and source of permissible waste delivered to the disposal site will be documented in the operating record. Additional documentation required as operating records are Access Records and Inspection Checklists.

\subsection{Cover and Llft Control}

Cover material will consist of native soil obtained from a bortow pit south of the disposal site which provided soil for the barrier layer.

\subsection{0.] Cells/Compaction}

Waste will be spread evenly and compacted to form a lift which will not vary by more than $0.6 \mathrm{~m}$ $(2.0 \mathrm{ft})$ along the face. The beight of the lift can vary but shail not exceed $2.0 \mathrm{~m}(6.0 \mathrm{ft})$. Each lift will be covered with at least six inches of compacted earthen material. Compaction will be uniform making at least two passes with a D-8 bulldozer or an equivalent piece of equipment.

Waste, which has confined open areas (i.e., storage tanks, vehicles), will be filled with native soil or other inert material so that more than 90 percent of the original volume will remain filled when compacted. Bulky jtems will be covered with the major axis horizontal to minimize the lift height.

It is expected that large quantities of combustible construction and demolition debris will not be disposed in the site. Therefore, the requirements of NAC 444.652, which require cross-sectioned cells separated by compacted cover material, are not applicable. 


\subsubsection{Operational/"emporary Cover}

Permissible waste will be covered daily, as required by NAC 444.688 . The operational cover will consist of native material compacted to a layer which is at least six inches thick using a D-8 dozer or equivalent piece of equipment. It will be graded to disperse direct rainfall on the disposal site and maximize evaporation of the water. Cracks, depressions, and erosion will be promptly repaired to maintain the cover's integrity. A temporary cover, consisting of at least $30 \mathrm{~cm}$ (12 in) of compacted earthen material, will be placed on waste disposal areas which have not received waste for more than 90 days.

\subsection{Dust Control}

Water trucks containing non-potable water will be used to suppress dust on the compacted dirt roads, as necessary, and during operations involving the compaction of cover material or the production of borow material.

\subsection{Litter Control}

WW personnel will remove, on a continuing basis, windblown material collected on the fence surrounding the disposal site. Scavenging and salvaging are not permitted in the disposal site.

\subsection{Vextor Contral}

Pathological waste (dead animals) and putrescible animal and vegetable waste from food service operations will be covered immediately. Pathological waste will be dispersed to the degree practical, throughout the non-putrescible waste.

The only disease that is common to the area is the hantavirus. Disposal site personnel are trained on proper management of rodent feces to include disinfection techniques and wearing proper personal protective equipment.

\subsection{Fire Protection}

Open burning of solid waste is prohibited by NAC 444.6675. However, fires could be initiated through malfunctioning electrical devices or disposal site equipment. Fire extinguishers are located in the base station and on disposal site equipment.

Disposal site personnel will use hand held fire extinguishers to control small fires. Where fires cannot be extinguished with small, hand held extinguishers, the NTS Fire Department will be notified by calling 911 on the telephone or using a "Mayday" signal on the NTS radio communication system. Under no circumstances will disposal site operators attempt to extinguish a large fire without instructions from the NTS Fire Department.

The fire station serving the disposal site is located in Area 6 (approximately 18 miles away) and operates 24 hours per day, seven days a week. 


\subsection{Methane Gas/Explosive Gas Monitoring}

It is not anticipated that the waste and environmental media will generate methane gases. Based on the physical and chemical composition of the buried material and low annual rainfall at the disposal site, the generation and accumulation of explosive or toxic gases is considered minimal or non-existent. Therefore, methane gastexplosive gas monitoring is not considered necessary.

\subsection{Unforeseen Circumstances}

\subsubsection{Medical Emeraency}

Emergency medical services are located in Area 6, approximately 18 miles away. This facility operates 24 hours per day, 365 days per year. Disposal site personnel may contact Medical Services by calling 911 or by using a "Mayday" signal on the NTS radio communication system. Additional emergency services are available throught the Fire Department (Section 9.14).

\subsubsection{Natural Events}

The disposal site is protected from runon water through flood channel control and compacted soil berms. However, rainfall falling directly on the site may result in muddy conditions which require that the site be closed for a short period of time until additional native soil is added to muddy areas to provide a workable surface.

\subsubsection{Equipment Failure}

Equipment at the disposal site will be maintained to prevent failure. However, there may be circumstances where equipment failure may occur; and the equipment cannot be repaired in a timely manner. Backup equipment (i.e., loaders, scrapers, dozers) will be obtained from other NTS operations to provide, as a minimum, an operational cover in the interim while the equipment dedicated for the disposal site is being repaired.

\subsection{Site Inspections}

The disposal site will be inspected semi-monthly (twice a month). The inspection will consist of the following items:

- Erosion of the berm or walls;

- Settling of the covered material;

- Condition of fencing;

- Condition of roadway;

- Accumulation of litter; and

- Accumulation of water.

Each inspection will be noted in the log. Corrective measures will be taken as soon as possible to correct the deficiency. All conrective measures and their completion dates will be noted in the $\log$. 
Where there is an excessive accumulation of water, the approximate area and depth of the ponded water will be noted in the log.

\subsection{Solid Waste Report}

A solid waste report will be sent semi-annually to NDEP/BFF. The report will include the quarterly totals of weight of permissible waste received, weight of PCB bulk product waste disposed, exceptions to the WAC, and whether the waste was generated from NTS operations, or onsitefoffsite FFACO operations. Each calendar year serves as the reporting period. 
10.0 Closure Plan

NDEP/BFF will be notified in writing of an intent to close the disposal site at teast 15 days before beginning closue activities. Closure activities will cornmence within 30 days of written acceptance of the plan by NDEP/BFF and will be completed within 180 days after beginning the closure.

It is anticipated that the disposal site will be used until permissible waste reaches an elevation of approximately $1,298 \mathrm{~m}(4,260 \mathrm{ft})$ on the north and northwest side and $1,294 \mathrm{~m}(4,245 \mathrm{ft})$ on the south and southeast side (see Figure 7). The final design will incorporate a cap configuration which will have a slope of not less than three percent to the center and be graded along the sides to drain surface water into the borrow pit south of the disposal site. The southern and eastern edges of the closure cap will have an adequately designed drainage channel arrangement which will prohibit water from entering adjacent subsidence craters. This will prevent water from entering a potential preferential pathway to groundwater.

The cover will consist of an infiltration layer containing a minimum $0.46 \mathrm{~m}$ (18 in) of earthen material having a capability that is less than the permeability of the natural subsoils, but not greater than $\mathrm{l} \times 10^{-5} \mathrm{~cm} / \mathrm{sec}$. Quality assurance checks will guarantee that the infiltration layer has met the specification requirements before completion of the final cover. An erosion layer, consisting of at least $15.2 \mathrm{~cm}$ ( $6 \mathrm{in}$ ) of native soil, will be placed on the infiltration layer. The erosion layer will be vegetated with native plants to stabilize the surface and reduce wind and water erosion.

An alternative design may be recommended at the time of closure which meets or exceeds infiltration requirements, controls erosion, maintains cover stability, and protects ground waters of the state of Nevada.

The closure plan will address all steps which will be taken to complete closure. This information will consist of a plan discussing the cover specifications, an estimate of the total volume of waste placed in the disposal site during its lifetine, decommissioning of any equipment or structures, and the installation of water, vadose zone, and/or gas monitoring devices, as required. The plan will meet all applicable regulations and will follow all relevant and appropriate regulations to the extent possible. Closure activities will commence within 30 days of written acceptance of the plan by $N D E P / B F F$ and will be completed within 180 days after beginning the closure. 


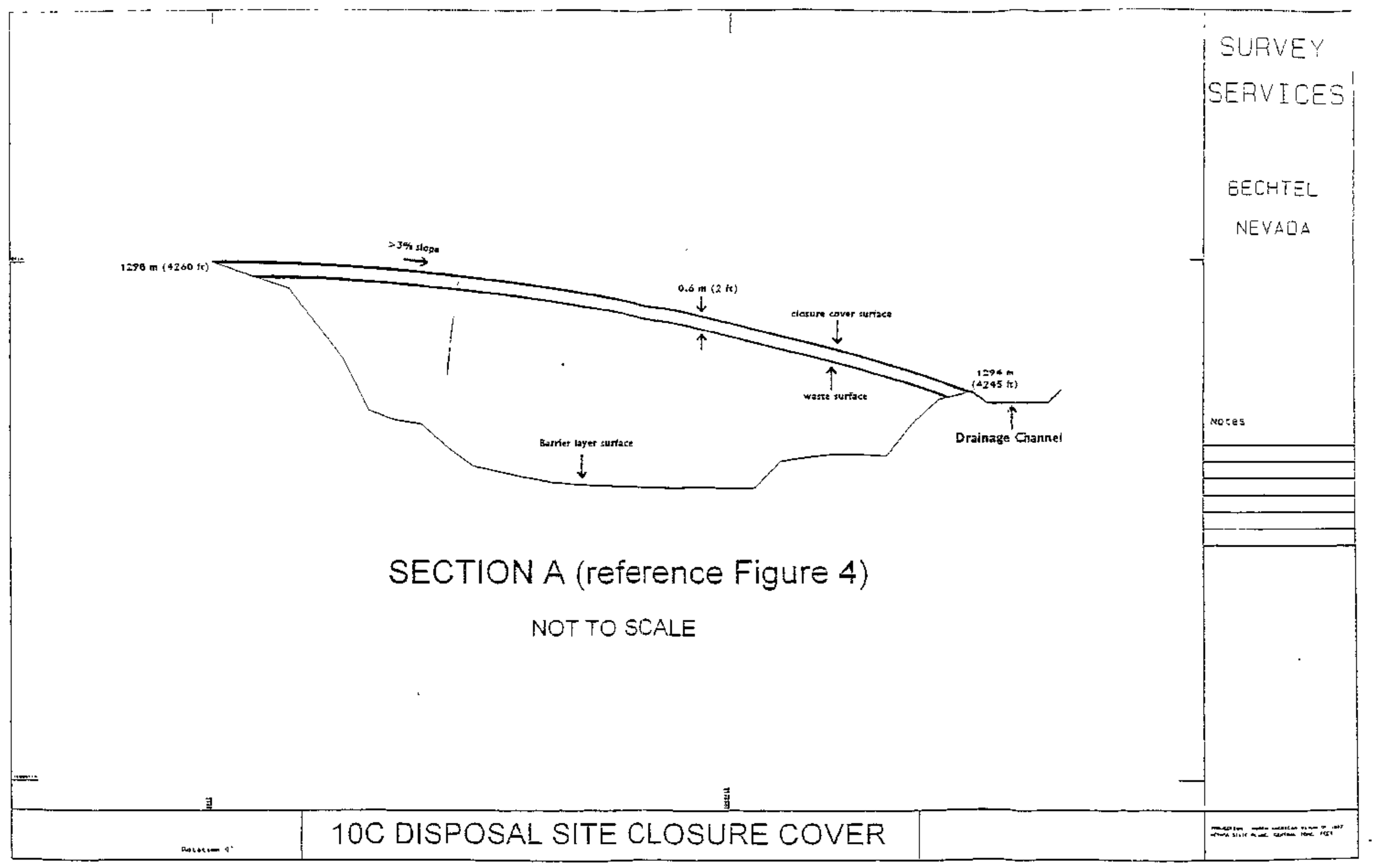




\subsection{Post-Closure Plan}

The post-closure program will:

- Maintain the integrity and effectiveness of the final cover;

- Correct the effects of settlement, subsidence, erosion, or other circumstances, whjeh may effect the integrity of the final cover

- Demonstrate at closure that any leachate is present or demonstrate that any leachate does not pose a threat to public health and safety and the enviromment;

- Monitor groundwater or demonstrate that any leachate does not pose a threat to public bealth and safety and the environment (post-closure groundwater monitoring will be contingent upon discovery of large amounts of leachate); and

- Monitor gas or to demonstrate that any potential gas generation does not pose a threat to public health and safety and the environment.

The post-closure program will be conducted for a period of 30 years. However, the land managet/operator maintains the right to request a wajer from the items listod above or request a waiver in the time period, if it can be demonstrated that a less extensive program is sufficient to protect public health and safety and the environment. 


\subsection{References}

Clark County Regional Flood Control District, Hydrologic Criteria and Drainage Design Manual, Las Vegas, Nevada, 1990.

Desert Research Institute (DRJ), CERCLA Preliminary Assessment of DOE's Nevada Operations Once Nuctear Weapons Test Areas, Las Vegas, NSO, 1988.

Energy Research and Development Administration, Final Environmental lmpact Statement, Nevada Test Site, Nye County, Nevada, ERDA-1551, Seplember 1977.

Federal Emergency Management Agency, Flood Insurance Study; Guidelines and Specifications for Study Contractors. Washington, DC (FEMA 37), 1991.

Fischer, J. M., Sediment Properties and Water Movement Through Shallow Unsaturated Alluviun at an Arid Site for Disposal of Low-Level Radioactive Waste Near Beatty, Nevada, U.S. Geological Survey Water Resources Investigation Report 92-4032, 1992.

French, R. H., Letter report on "FY-93 Evaporation Studies at ER 6-1 Ponds" to Stephen J. J. Lawrence, U.S. Department of Energy Environmental Restoration and Waste Management, Desert Research listitute/Water Resources Center, September 29, 1993.

Nichols, W.D., Geohydrology of the Unsaturated Zone at the Burial Site for Low-Level Radioactive Waste Near Beaty, Nye County, Nevada, U.S. Geological Survey Open File Report 85-198, 1987.

O'Neiil, L., et al., A Case for Resource Conservation and Recovery Act (RCRA) "No Migration" Variance and Land Disposal of Mixed Land Disposal Restrictions (LDR)Waste at the Nevada Test Site (NTS), Proceedings of the Symposium on Waste Management, Tucson, Arizona, February 28 - March 4, 1993, pp. 1333-1346.

Raytheon Services Nevada, [Review Drafl] Flood Assessment at the Area 6 Proposed Liquid Waste Treatment System, DOE/Nevada Test Site, Nye Count;; Nevada, May 1994.

Quiring, R. F., Climatological Data, Nevada Test Sile and Nuclear Rocket Development Station, U.S. Department of Commerce, Environmental Sciences and Services Administration Report ERLTM-ARL 7, 1968.

U.S. Army Corp of Engineers, Flood Hydrograph Package (HEC-I Computer Program Version 4.0), Daviș, Califortia, September 1990.

Williams, W. P., Surface Effects from Underground Tests of the U10c and U9ar Sites, Yucca Flat. Nevada Test Site, U.S. Geological Survey, Technical Letter NTS-89, May 26, 1965. 
Winograd, I. J. and W. Thordarson, U.S. Geological Survey, Hydrogeologic and Hydrochemical Framework, South-Central Great Basin, Nevada-California, with Special Reference to the Nevada Test Site, Professional Paper 712 C, 1975. 
Appendix A

U10C Class III Disposat Site Construction of a Temporary Barrier 


\section{U10c Class III Disposal Site Construction of a Temporary Barrier}

Construction Summary Report

prepared by:

Raytheon Services Nevada

December 20, 1995 


\section{U10C Class III Disposal Site Temporary Barrier Construction Summary Report}

I

CONSTRUCTION SUMMARY

RSN, AEECo and DOE assembled a team of engineers and scientists to develop plans for the construction of a compacted earthen barrier for the U10c disposal site on the Nevada Test Site (NTS). From a borrow pit located southeast of the disposal site, fill material was conveyed and compacted to at least $90 \%$ using heavy equipment. The bottom of the disposal site was elevated by four feet of earthen material. An additional one foot of earthen material was added to the middle of the disposal site which accumulates water during intense storm events. The project team has reviewed all design and construction requirements and have determined that the barrier at U100 disposal site exceeds minimum standards.

\section{DESIGN RATIONAL}

The design of the barrier is based on all water within the disposal site draining into a centralized accumulation area. The size of the barrier underneath this accumulation area would be increased by the addition of earthen material. This would increase the evaporation and transpiration performance of the barrier.

The boundary of the disposal site is approximately 28 acres with the disposat site comprising about 17 acres. The hydraulic pressure on the barrier's surface from a 25 year, 24 hour precipitation is about 3.5 inches. The project team determined that increasing the barrier thickness to five feet at the storm water accumulation area in the disposal site would be sufficient to prevent significant percolation of moisture through the waste. With the installation of six neutron monitoring wells, engineers and scientists can monitor the performance of the barrier and determine the course of corrective actions, if required. Attached are complete design drawings tor the disposal site (JS-00910C-T1, $\mathrm{C} 1$ and $\mathrm{C} 2$ ).

Soil samples from the borrow area were tested to have a saturated permeability of approximately $7.9 \mathrm{E}-06$ centimeters per second. All rocks larger than $3^{\prime \prime}$ were removed. The engineering drawings required the earthen soil be spread into three inch lifts and compacted to $90 \%$. A minimum of four foot of native material was placed over sloped areas within the disposal site which contains solid waste. The thickness of the barrier will provide the necessary erosion and hydraulic performance for this disposal site. 


\section{U10c Class III Disposal Site Temporary Barrier Construction Summary Report}

\section{SUMMARY OF CONSTRUCTION ACTIVITIES}

A pre-construction meeting was held October 5, 1995 . Members of the NTS project team were present. The team included personnei from REECo (construction, waste operations and field supervision). RSN (survey, inspection and project management) and DOE (engineering) departments or divisions. The design rationale, quality assurance testing (i,e. density) and project schedule were discussed so the project team could make informed decisions during the construction of the barrier.

\section{LIFT DIMENSIONS}

Native material was placed in three inch loose lifts. Alt material larger than three inches was removed prior to placement in the bottom of the disposal site. Non-potable water trucks were used both in the borrow pit and in the disposal site to provide the necessary moisture for compaction and dust suppression. Heavy equipmenl placed additional three inch loose ints while compacting the previous lifts using the wheel action of the scrapers, water trucks, sheep foot rollers and dozers. Additional lifts were added until a twelve inch thick compacted layer was established. The process was repeated until the disposal site achieved the desired barrier thickness (i.en, four feet).

\section{QUALITY ASSURANCE TESTING}

REECO construction personnel pertormed quatity assurance density tests throughout construction to insure the design requirements were met. Originally, the project team required measurements to be taken every 1,000 cubic yards. After further review, the project team determined to analyze the barrier's compaction on an informal basis at nine specific locations. The nine test locations were the mid-points between the neutron access tubes in the bottom of the disposal site. See the attached "Practical Sampling Design" sketch for the testing locations and the "NTS Inspection - Daiky inspection Log's" for density test values. REECo would perform the density tests which were witnessed and documented by RSN inspection personnel. The quality assurance tests indicate that the barrier has an average density compaction of $94.3 \%$. The quality assurance tests ranged from $90.2 \%$ to $103.4 \%$ compaction with over $40 \%$ of the tests having a density between $91 \%$ and $92 \%$. 


\section{U10e Class III Disposal Site Temporary Barrier Construction Summary: Report}

\section{SURVEY}

in order to document the entire construction activity at U106 disposal site, surveys were completed before and after construction. See the attached "10c Pre-Construction Topo" and "Final 10c Topo" drawings. A comparison of these two drawings shows that a four foot barrier was constructed with five foot of compacted native material underneath the intense storm events accumulation area.

\section{FIRST FILL OPERATION}

During the initial survey of the disposal site, the project team met to review all construction activities. The project team agreed that the bottor of the disposal site would be brought up to an elevation of 4,220 feet using the native material. Four fool of compacted material would be placed over sloped areas in the disposal site. The project team laid out the necessary grade staking indicators besed on the results of the survey. Equipment and personnel were mobilized beginning on October 16, 1995. Construction of the barrier began on October 18, 1995. By November 2, 1995, over 100,000 cubic yards of native 1 material was placed in the bottom of the disposal site. The survey results indicated the four foot barrier was constructed (elevation 4,220). Construction activities were suspended until the survey of the disposal site was completed (1st progress survey).

\section{SECOND FILL OPERATION}

The first progress survey showed that all of the first goals had been met, but the gently sloping area in the west side of the disposal site had insufficient cover material. The project tearn agreed that the area between elevation 4220 feet on the east and 4225 feet on the west would be tilled using native material. The project team laid out the necessary grade staking indicators based upon the first progress survey. Construction began on Novernber 20, 1995 and by November 23,1995, over 11,000 cubic yards of native soil was placed in the deficient area. Construction activities were again suspended until a survey of the disposal site was completed ( 2 nd progress survey). 


\section{U10c Class III Disposal Site Temporary Barrier Construction Summary Report}

\section{THIRD FILL OPERATION}

The second progress survey showed that the requirements outlined in the construction drawings were achieved. After final review, the project team determined that the best management practice for the disposal site would be to add additional soil to the southwest comer where the disposal site access road enters the bottom of the disposal site. Survey crews laid out the remaining stakes used for grading. By November 28,1995 , an additional 2,000 cubic yards of native soil was added to the southwest corner of the disposal site. The post construction surey was initiated and completed. The project team reviewed the before and after survey drawings. The project team agreed that all requirements in the engineering drawings were met or exceeded and the disposal site has a four foot compacted soil barrier.

\section{NEUTRON ACCESS TUBE INSTALLATION}

By December 14, 1995, five neutron access tubes were placed in the compacted earthen barrier. One additional access tube was placed outside of the disposal unit boundary to monitor moisture through undisturbed land. The tubes are made out of $3 / 4$ inch stainless steel and will be protected from equipment damage by a $31 / 2$ inch diameter schedule 40 aluminum alioy pipe mounted within a 4 loot diameter cylindrical concrete pipe.

\section{CONCLUSIONS}

In the construction of an earthen soil barrier for the U1Oc disposal site, all engineering parameters were met. These parameters inciude:

- a four foot barier;

- removal of rocks with a size of three inches or larger,

* native soil in lifts less than eight inches thick;

- $90 \%$ compaction and

* installation of neutron access tubes. 


\section{NTS INSPECTION - DAILY INSPECTION LOG NEVADA TEST SITE}

PROJECT : $10 \mathrm{C}$ Cater Chass ID Disposal Site Temp Banier

REPORT NO.

01

CONTRACTOR: BEECO

CONTRACT: W.O. H4074-108

INSPECTOR (S): Kirk Powellflurel Hughes

PAIP NO's ALER

DATE : $Q$ F. $18.1995,140$.

WEATHER: CLEER

TEMPERATLAE LOW 58 HIGH 83

SUPERVISION

CONTR/SUBCONTR.SUTT.

D. Finney

RSN PROJECT ENGRER:

R. Ziegenbein

\section{LABOR FORCE}

OPRS: 7 CRPN:__ IRWN:__ WRMN:__ MASN:__ SHMT:_ TMRS:
SURV: 1 LABR:__ LNMN:__ PNTR:__ INSUL:__ FTTRS:__

X ACTIVITY $\square$ SO ACTIVTTY REPORTED DURING THE FOLLOWING PERIOD: $1 \ldots$ THRU

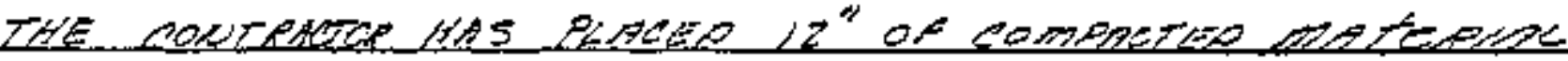

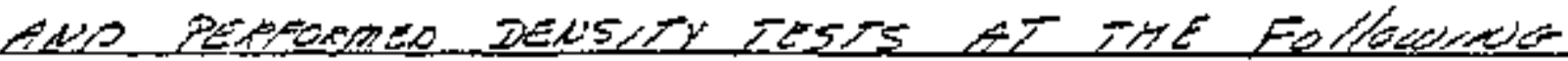

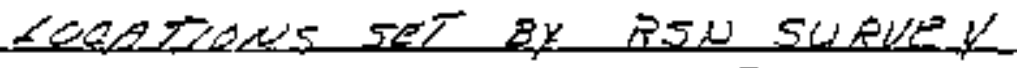

$$
\begin{aligned}
& \text { Polut }{ }^{2}=92,9 \quad{ }^{\top} 3=91,0 \quad 5=0.9 \\
& \text { REFEFUEE }=3 \mathrm{~S}-009-100-\mathrm{Cl}
\end{aligned}
$$

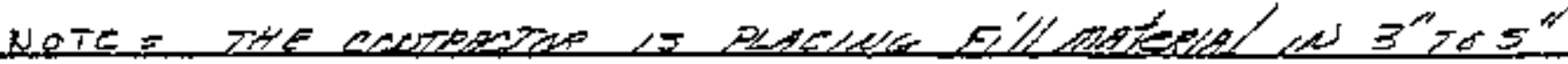

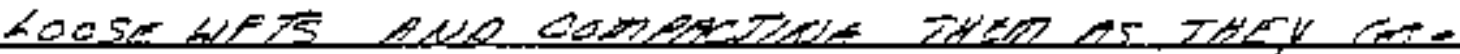

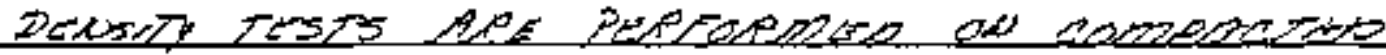

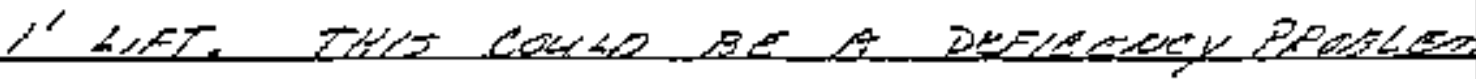

NO OTHEP WOPK WOS OLSWPUER 


\section{ORIGINAL \\ NTS INSPECTION - DAILY INSPECTION LOG \\ NEVADA TEST SITE}

PAGE $\angle O F \perp$

PROJECT: $10 C$ Crnter Class II Disposal Sile Temp. Barier

CONTRACTOR: REECO

CONTRACT: W.O. \#1074-108

INSPECTOR (S) : Kirk Powell/l aurel Huthes
REPORT NO:_ OZ PAII.P NO'S. $N$ VAREZ $/ * * *$

DATE: $Q 2 T / E, M O S$

WEATHER: $Q \angle \angle P P$

TEMPERATURE LOW $5 \%$ HIGH 83

SUPERVISION

\begin{tabular}{|c|c|c|c|}
\hline CONTRUSUBCONTR.SUPT. & D. Finney & RSN PROIECT ENGNEER: & R. Ziegenbein \\
\hline
\end{tabular}

LABOR FORCE

OPRS: 7 CRPN:__ IRWN:__ WRMN:__ MASN:___ SHMT:__TMRS:
SURV: 1 LABR:___ LNMN:__ PNTR:__ INSUL:__ FTRS:__

\section{ACTIVITY $\square$ NOACTIVTTY REPORTED DURING THE FOLLOWING PERIOD:}

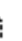
THRU

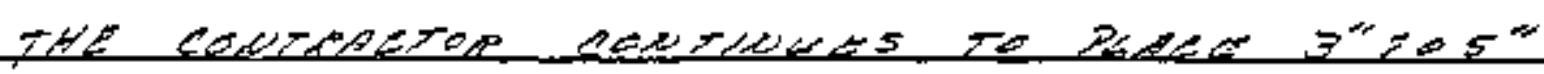

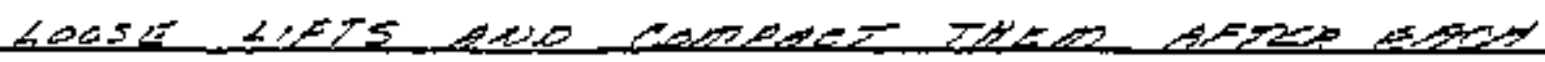

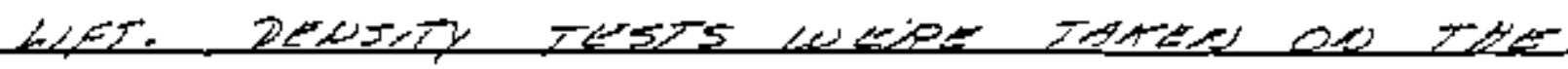

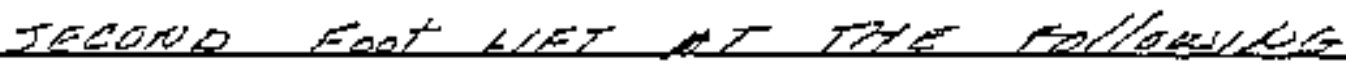

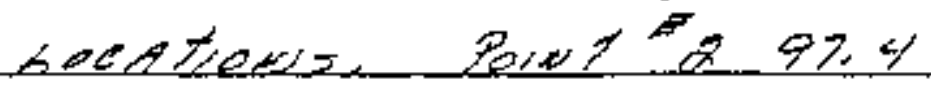

$$
\begin{aligned}
& 731010 \\
& 7497.2 \\
& 592.9
\end{aligned}
$$

PEFERCAOL= J5.000-10L-CL 


\section{ORIGINAL \\ PAGE $\angle O F$ \\ NTS INSPECTION - DAILY INSPECTION LOG \\ NEVADA TEST SITE}

PROJECT: IOC Coler Class_L_Disposal Sile Temp Bamier

CONTRACTOR : REECO

CONTRACT. W.O. \#4074-108

INSPECTOR (S): Kirk PowelII awrel Hughes
REPORTNO: CS

PAIIP NÖS NVESOLF*

WEATHER: ClEQR

TEMPERATURE LOW 4\% HIGH 6\% SUPERYISION

CONTRSUECONTR.SUPT.:

D. Finney

RSN PROJECT ENGNEER:

R. Ziegenbein

\section{LABOR FORCE}

OPRS 7 CRPN:__ IRWN:__ WRMN:__ MASN:__ SHMT:__ TMRS:
SURV:_L LABR:__LNMN:__ PNTR:__ INSUL:__ FTRS:__

Y ACTIVITY $\square$ NO ACTIVITY REPORTED DURING THE FOLLOWEIG PERIOD:

i

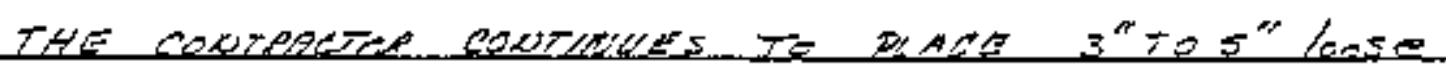

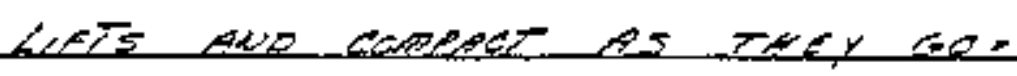

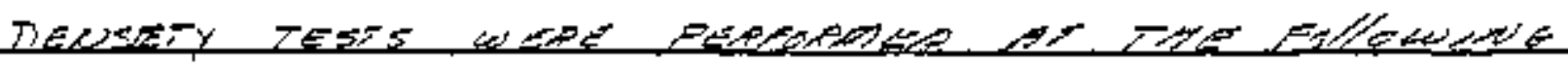

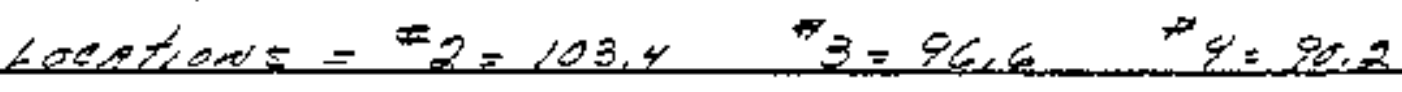
$5=1012 \quad \pi 8.90 \%$

Peftevece $=35-007-100-c 1$ 


\section{ORIGINAL}

PAGE 1 OF 1

NTS INSPECTION - DAIYY INSPECTION LOG NEVADA TEST SITE

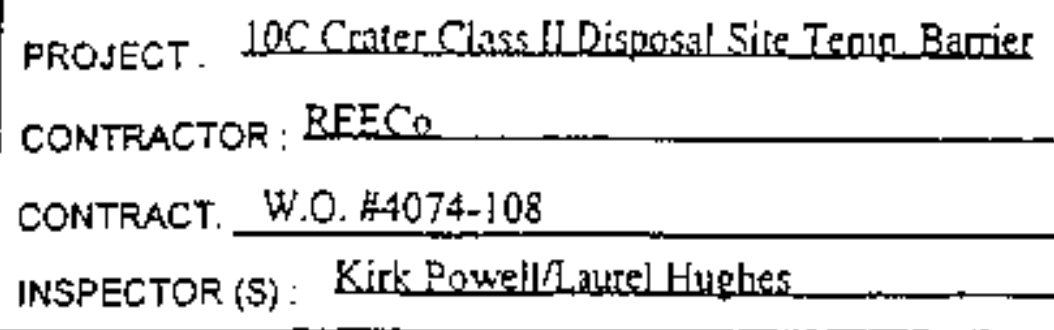

PROSECT. 10C Cater Class_LLDisposal Sice_tenon_Barier CONTRACTOR: REECO CONTRACT. W.0. H074-108 INSPECTOR (S): Kirts Powell Lautel Hughes REPORT NO: $\quad 04$ PAII.P NO'S. NVR 80?/\%** DATE : $10=9595$. WLEO WEATHER: C/ERL TEMPERATURE LOW \&/L HGH EY

\section{SUPERYISION}

CONTR/SUBCONTR.SUPT.:

D. Finney

RSN PROJECT ENGINEER:

R. Ziegenbein

\section{LABOR FORCE}

OPRS: $7 \ldots$ CRPN:__ IRWN:_ WRMN:_ MASN___ SHMT__ TMRS:
SURV: 1 LABR __ LNMN:__ PNTR__ INSUL:_ FTTRS:__

网 ACTIVITY $\square$ NO ACTIVTTY REPORTED DURING THE FOLLOWING PERIOD:

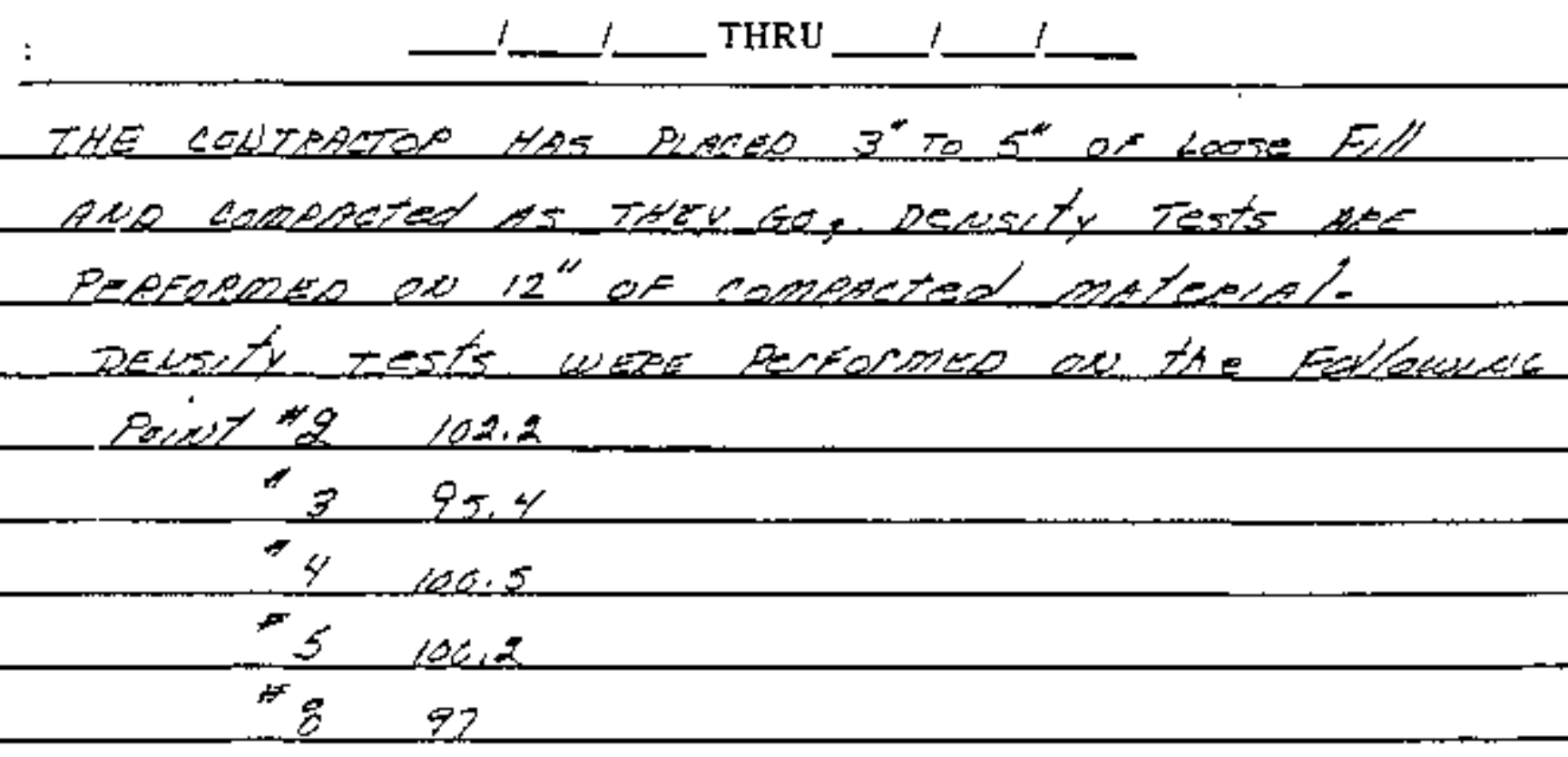

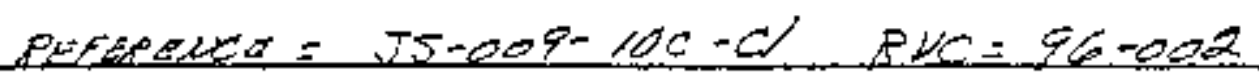

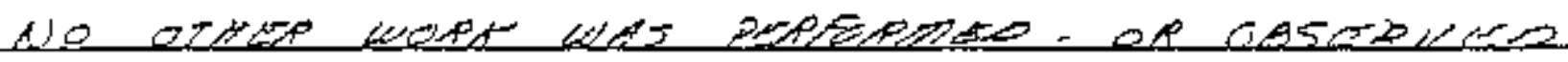




\section{NTS INSPECTION - DAILY INSPECTION LOG NEVADA TEST SITE}

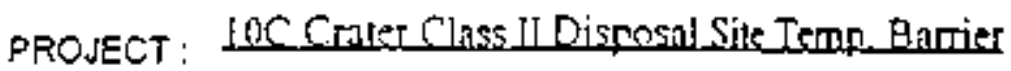
CONTRACTOR: REFCO

CONTRACT: W.O. $44074-108$

INSPECTOR (S) : Kitk: Powell/Laurel Hughter
REPORT NO: $\quad 05$

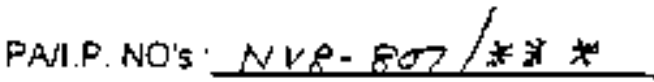

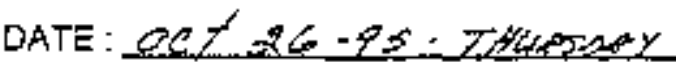

WEATHER: ClEAT

TEMPERATURE LOW 45 HIGH $Z$

SUPERVISION

CONTRSUBCONTR.SUPT.

D. Finney

RSN PROIECT ENGINEER:

R. Ziepenbein

\section{LABOR FORCE}

OPRS:_ ᄀ CRPN:___ IRWN:__ WRMN:__ MASN:__ SHMT:__ TMRS:
SURV:_ LABR:__ LNMN:__ PNTR:__ INSUL:___ FTTRS:___

प ACTIVITY $\square$ NO ACTIVTTY REPORTED DURING THE FOLLOWING PERIOD: $1+1$

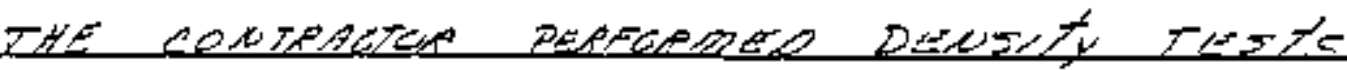

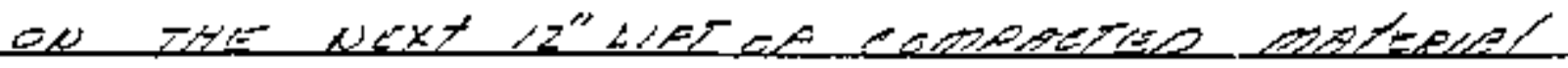

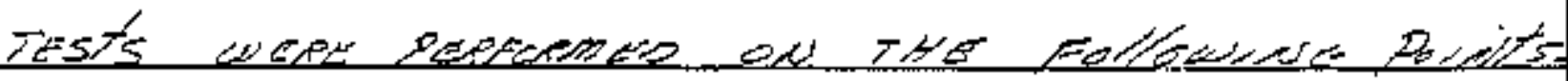
$71=921$.

$+6=97.0$

$77=97.2$

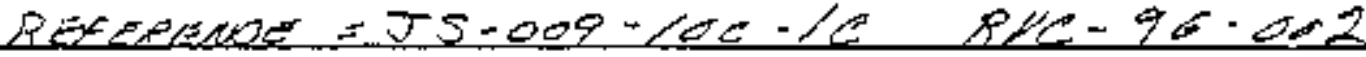

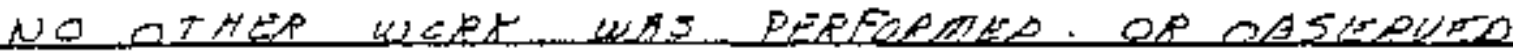




\section{ORIGINAL PAGE $\perp$ OF}

NTS INSPECTION - DAILY INSPECTION LOG NEVADA TEST SITE

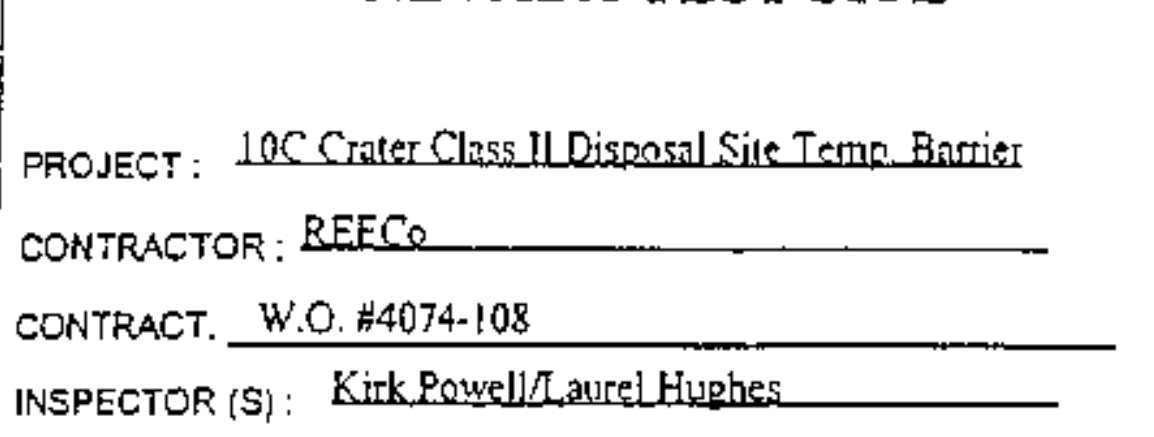

FEPORT NO:

06

PAIIP NO's NVA-RG2L * * *

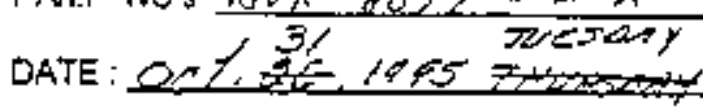
WEATHER: CLLEA

TEMPERATURE LOW $4 \delta$ HGH 70

\section{SUPERVISION}

CONTRSUBCONTE.SUPT:

D. Finney

RSN PROJECT ENGINEER:

R. Ziegenbein

\section{LABOR FORCE}

OPRS. $\_$CRPN:__ IRMN___ WRMN ___ MASN.__ SHMT.___ TMRS:
SURV:_ $\angle$ LABR:__ LNMN___ PNTR:___ INSUL:___ FTRS ___

ACTIVITY $\square$ NO ACTIVITY REPORTED DURING THE FOLLOWING PERIOD;

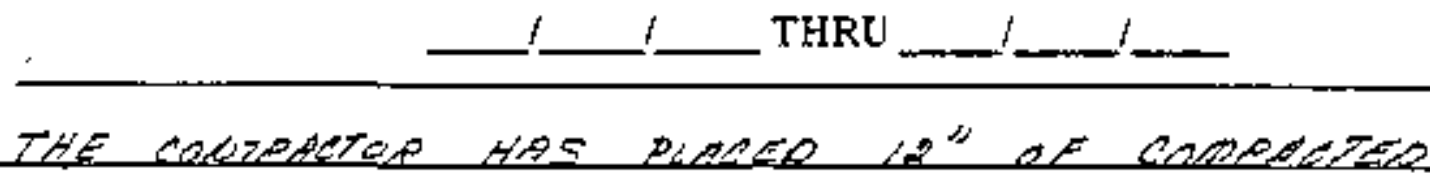

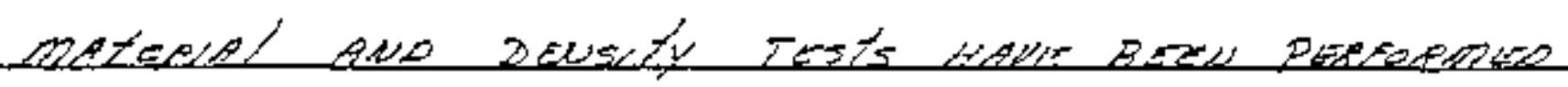

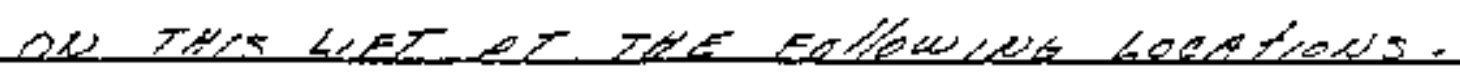

pot $7 \%=9 \%$,
$76=98,7$
77.919
$79 \quad 9 \% 3$

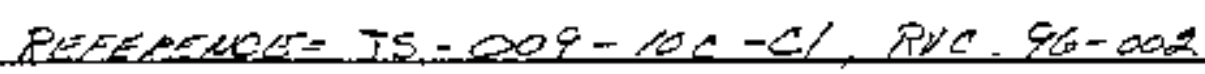

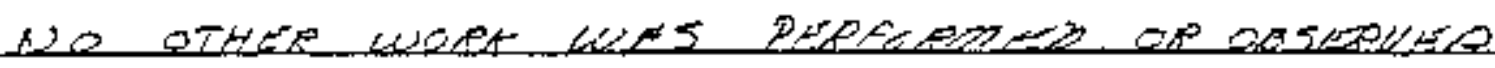




\section{NTS INSPECTION - DAILY INSPECTION LOG NEVADA TEST SITE}

PROJECT: 10C Coler Class It Disposal Site Temp Banier CONTRACTOR: REECO

CONTRACT: W.O.

INSPECTOR (S): Kirk Powellinarel Hughes
REPORT NO: $\quad 07$

PAI.P. NO'S LVRE.8O7/A.X.X

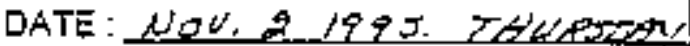

WEATHER: CLEAKA

TEMPERATURE LOW $\angle G$ HIGH

SUPERVISION

CONTR/SUBCONTR.SUPT:

D. Finney

RSH PROJECT ENGNEER:

R. Ziegenbein

LABOR FORCE

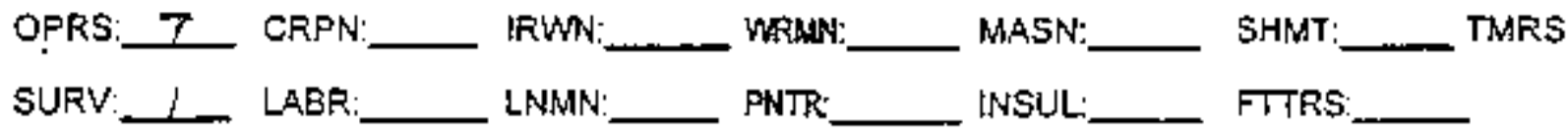

ACTIVITY $\square$ NO ACTIVITY REPORTED DURING THE FOLLOWING PERIOD:

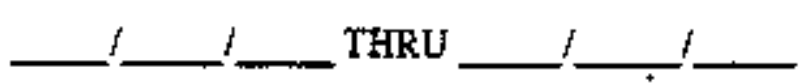

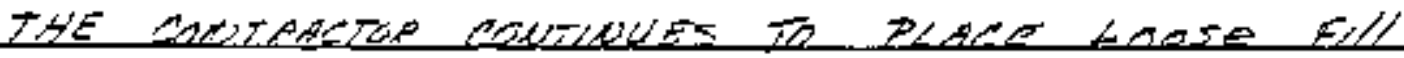

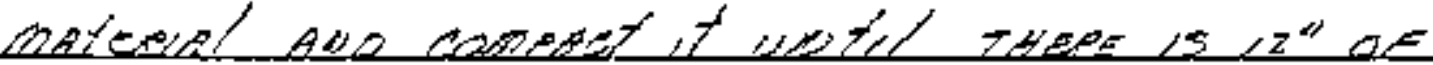

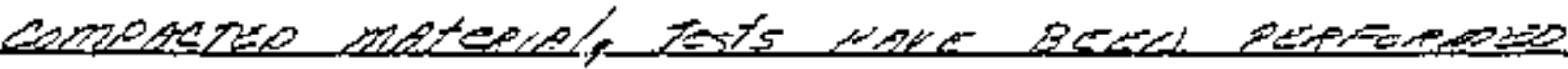
at EAcE W"

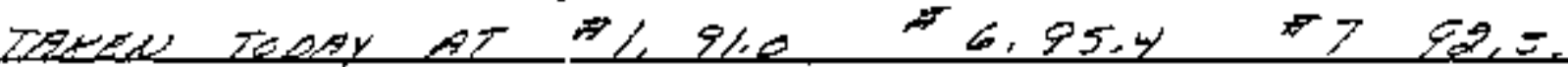

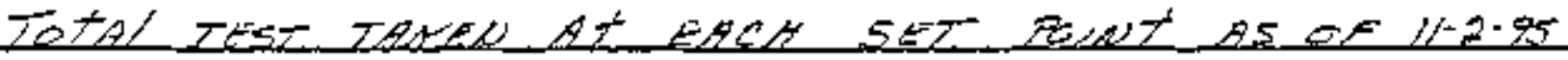
$A P+L=3 \quad F 5=4$ $2=4 \quad 56=3$

$\pi_{3}=4 \quad 77=3$
$+4=3$

PEFEAEUCE J5-009-10C-LI $59 \times 1$ $800+96-002$

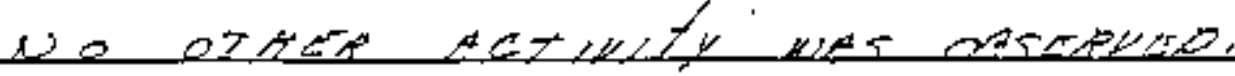




\section{PAGE _ L OF \\ NTS INSPECTION - DA
NEVADA TEST SITE}

\begin{tabular}{ll} 
\\
PRO \\
CON \\
CON \\
INSPP \\
\hline LAB \\
\hline
\end{tabular}

PROJECT: $10 \mathrm{C}$ Conter Class Ll Disnosal Site Temo Barrer CONTRACTÓ : RELCO

CONTRACT: W. \#4074-108

INSPECTOR (S): Kirk Powell/LaureL Hughes

REPORTNO: 08

PAVI.P NO'S. NVR-807/*K,

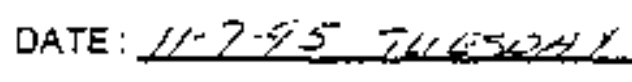

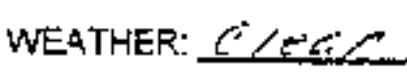

TEMPERATURE LOW $22 \mathrm{HIGH} \subseteq 8$

SUPERVISION

CONTRSUBCONTR.SUPT.: $\quad$ D. Finney $\quad$ RSN PROJECT ENGINEER. R. Ziegenbein

LABOR FORCE

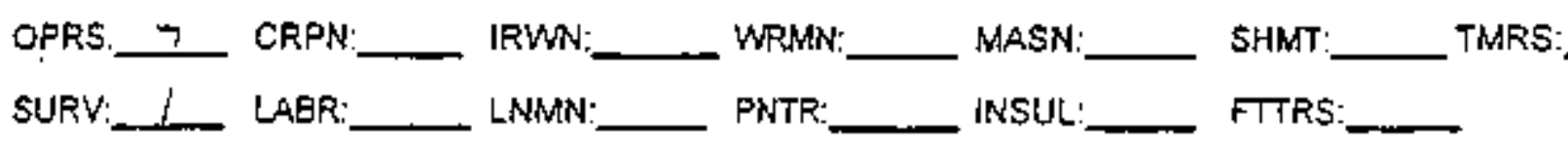

ACTIVITY $\square$ NOACTIVITY REPORTED DURING THE FOLLOWING PERIOD;

:

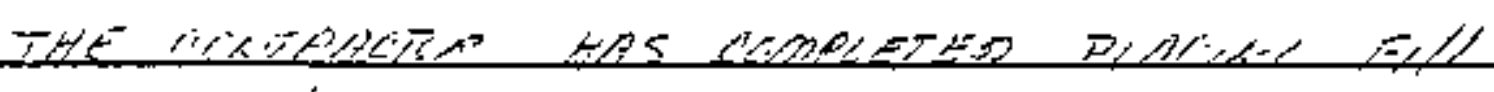

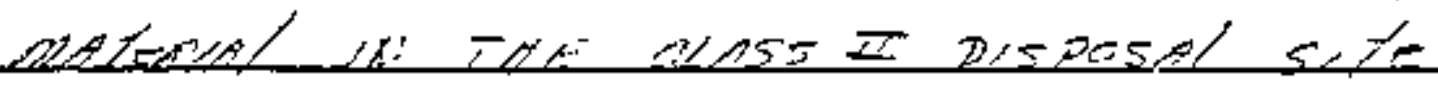
of loc ineter, Its bivine is of the

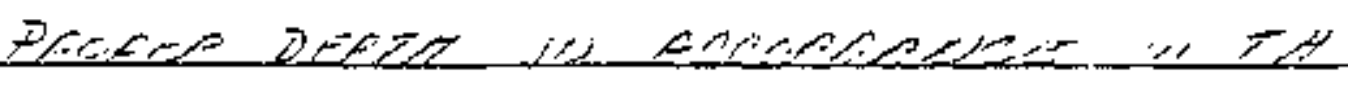

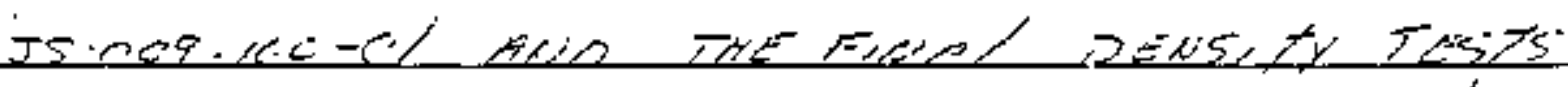

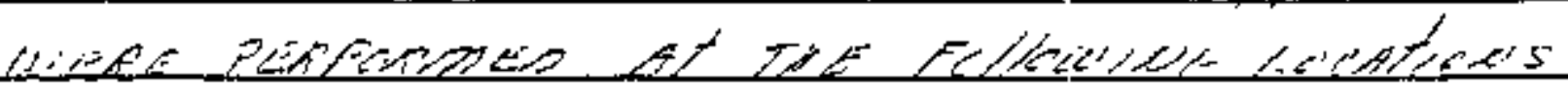

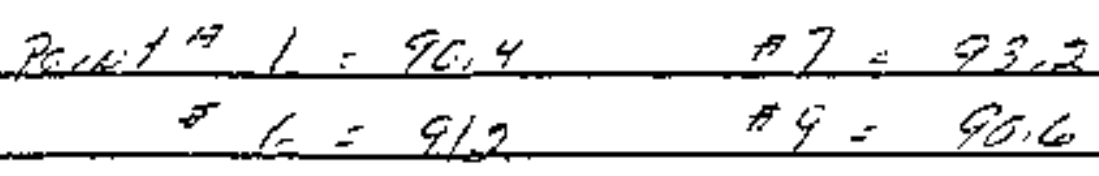

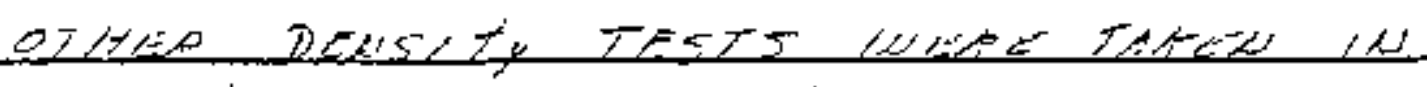

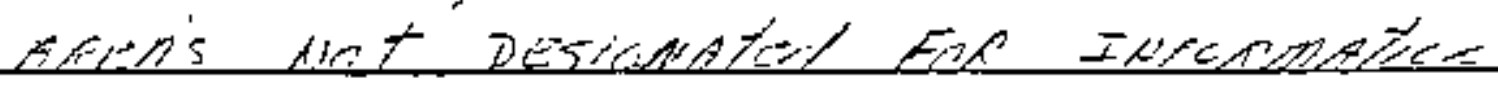

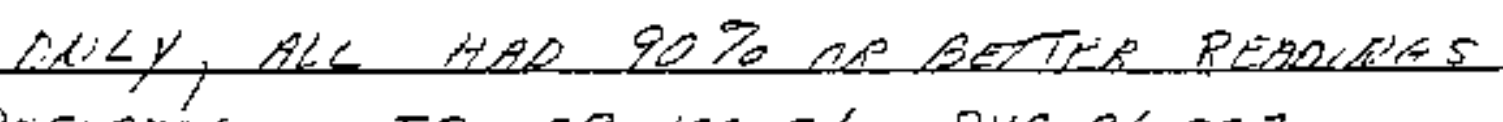

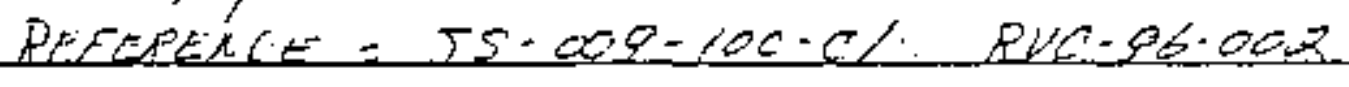

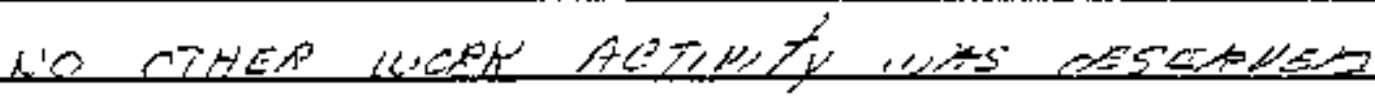


NTS INSPEETPONNALILY INSPECTION LOG NEVADA TEST SITE

PROJECT: lOC Crater Class II Disposal Site Temp. Bartier
CONTRACTOR : REECo
CONTRACT: $\frac{\text { W.O. \#4074-108 }}{\text { INSPECTOR (S): Laurel Hughes }}$

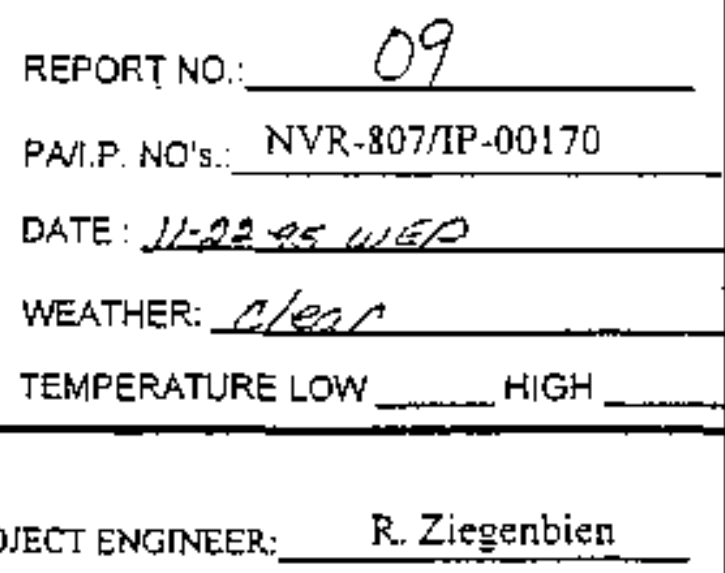

LABOR FORCE

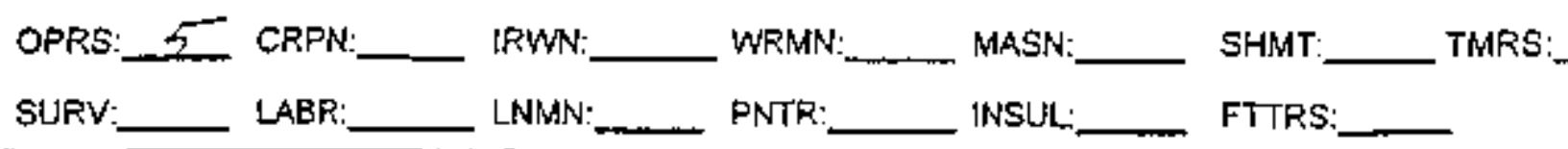

X ACTIVTTY $\square$ NO ACTIVTTY REPORTED DURING THE FOLLOWTNG PERIOD:

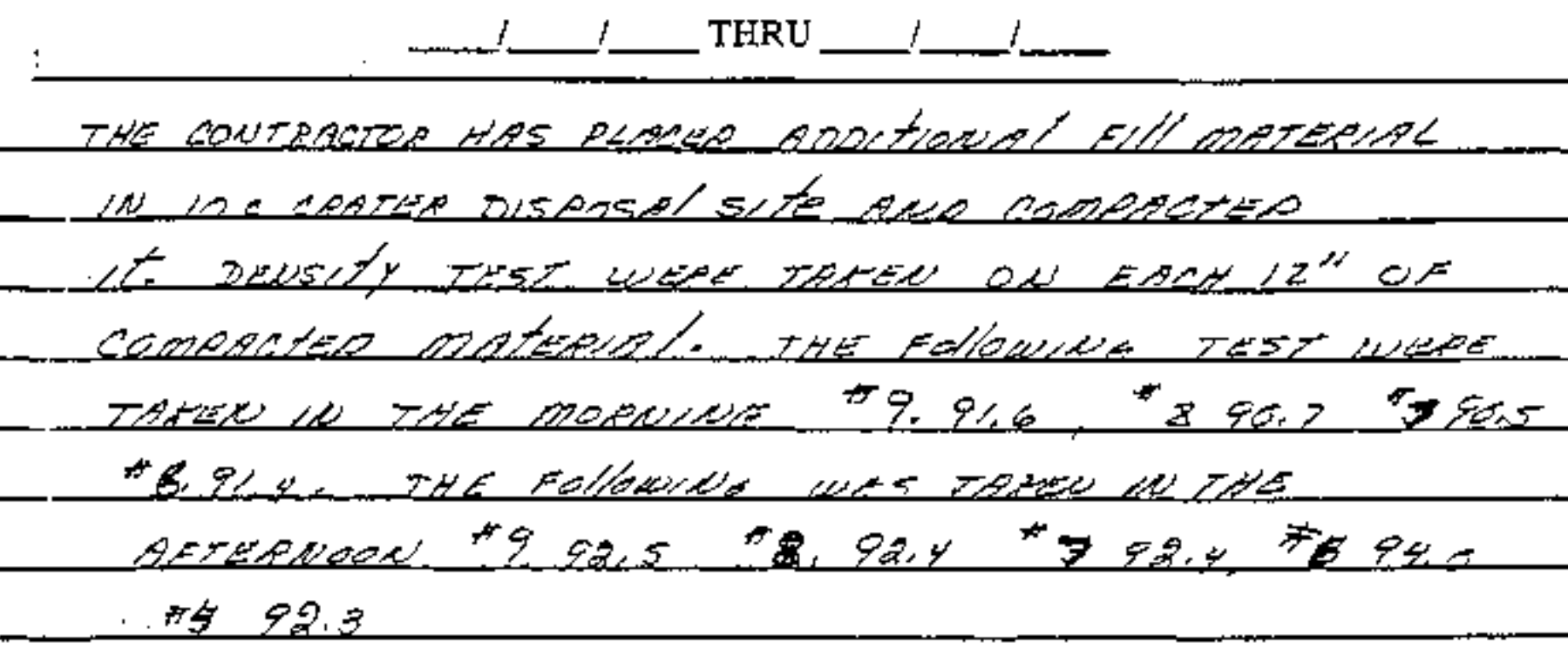

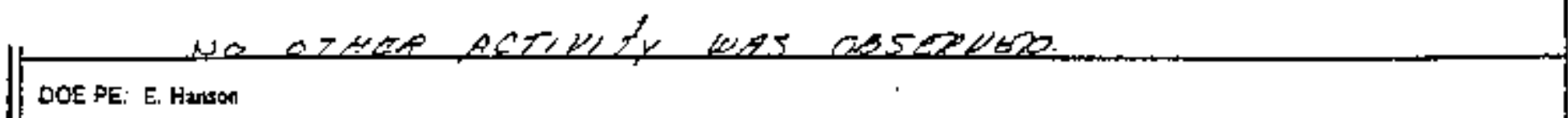




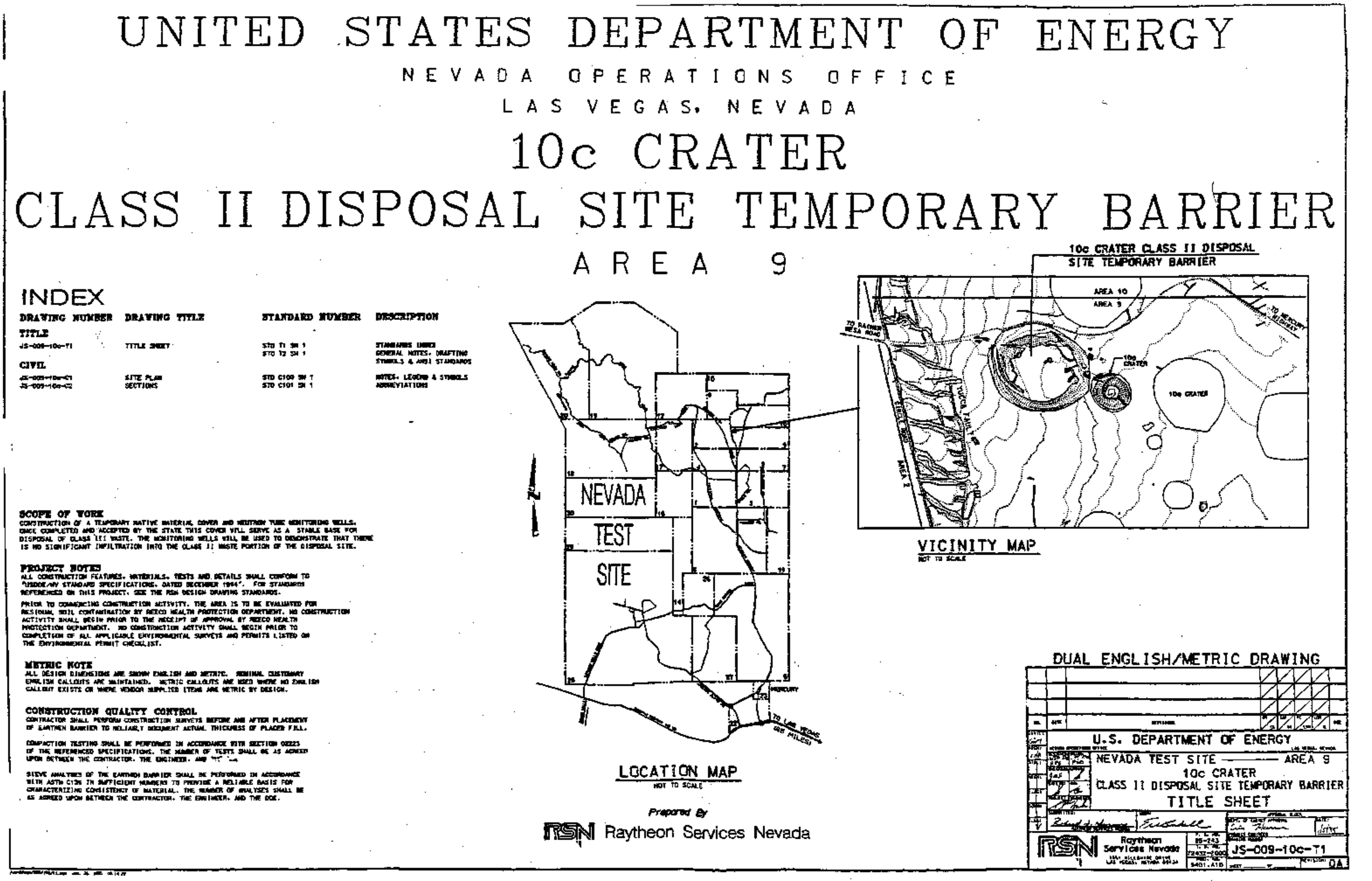




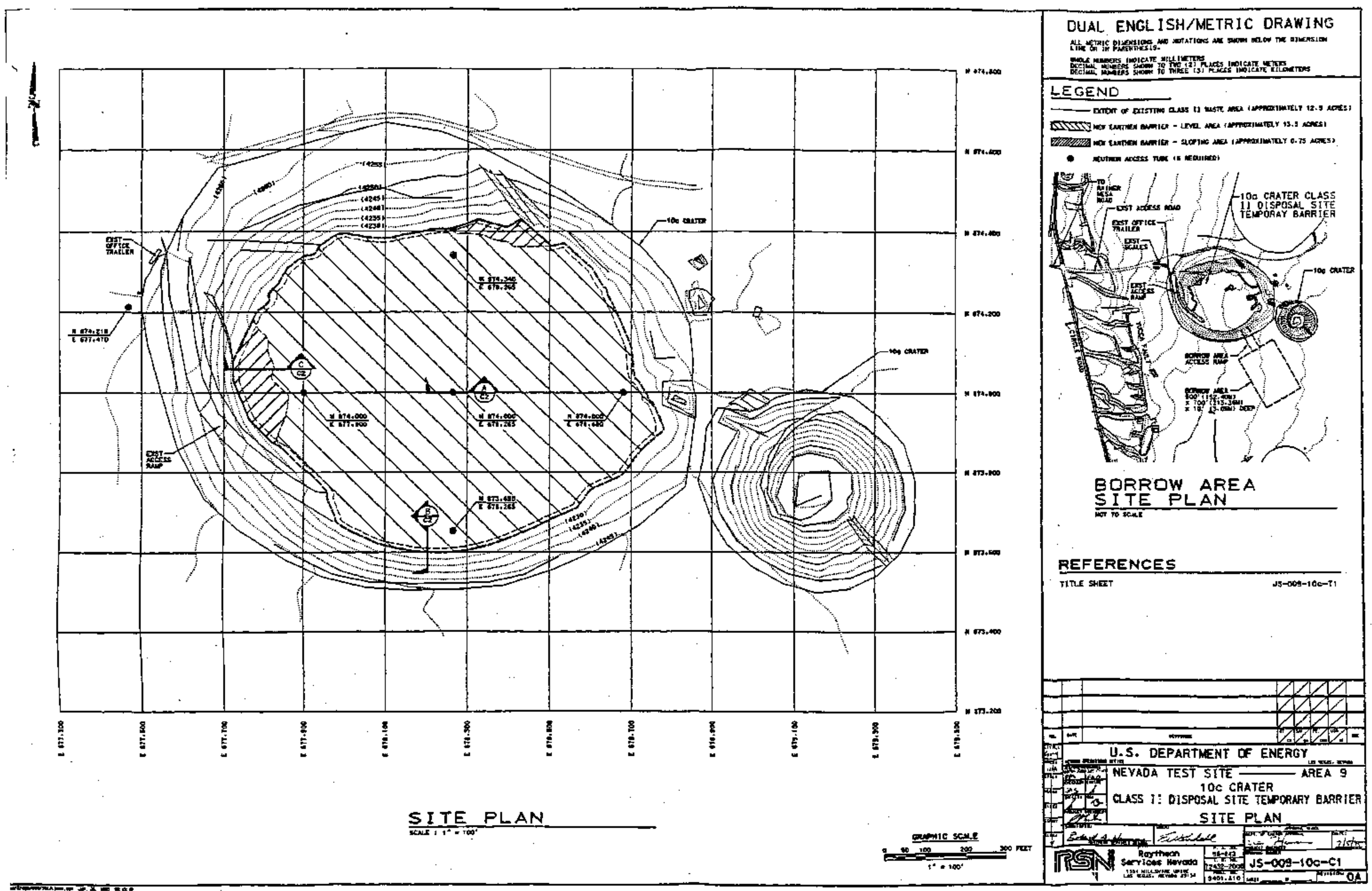




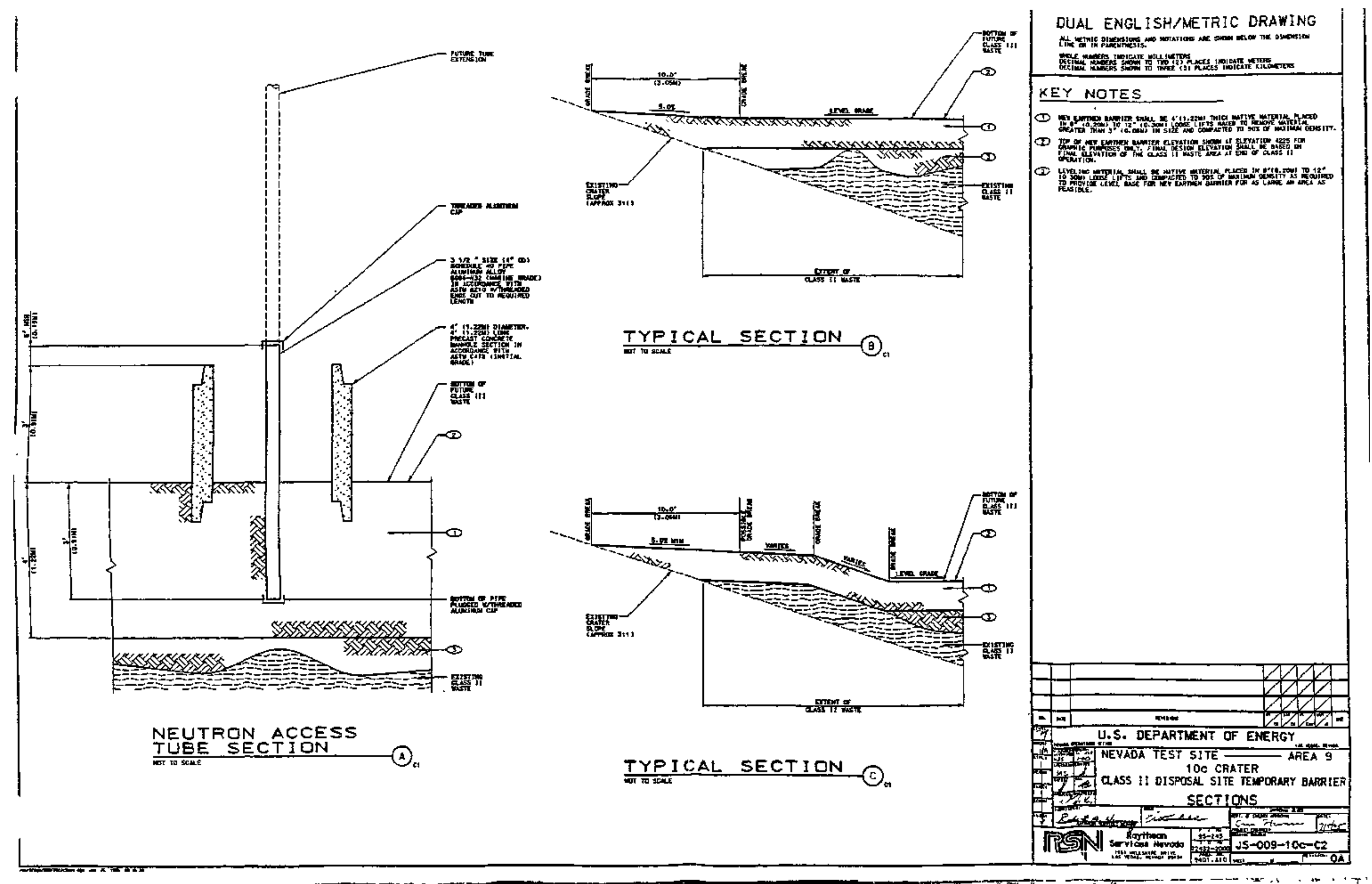




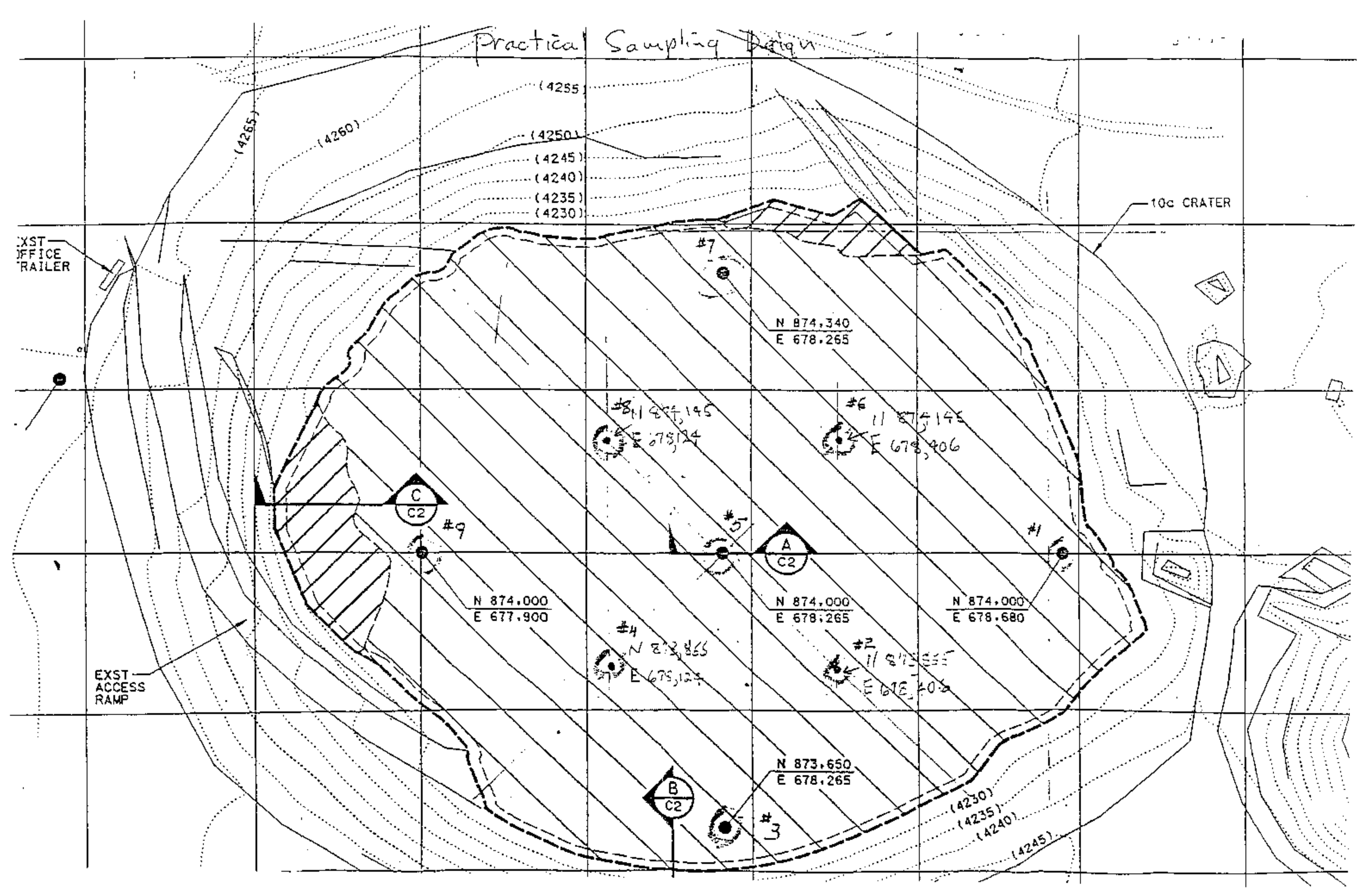




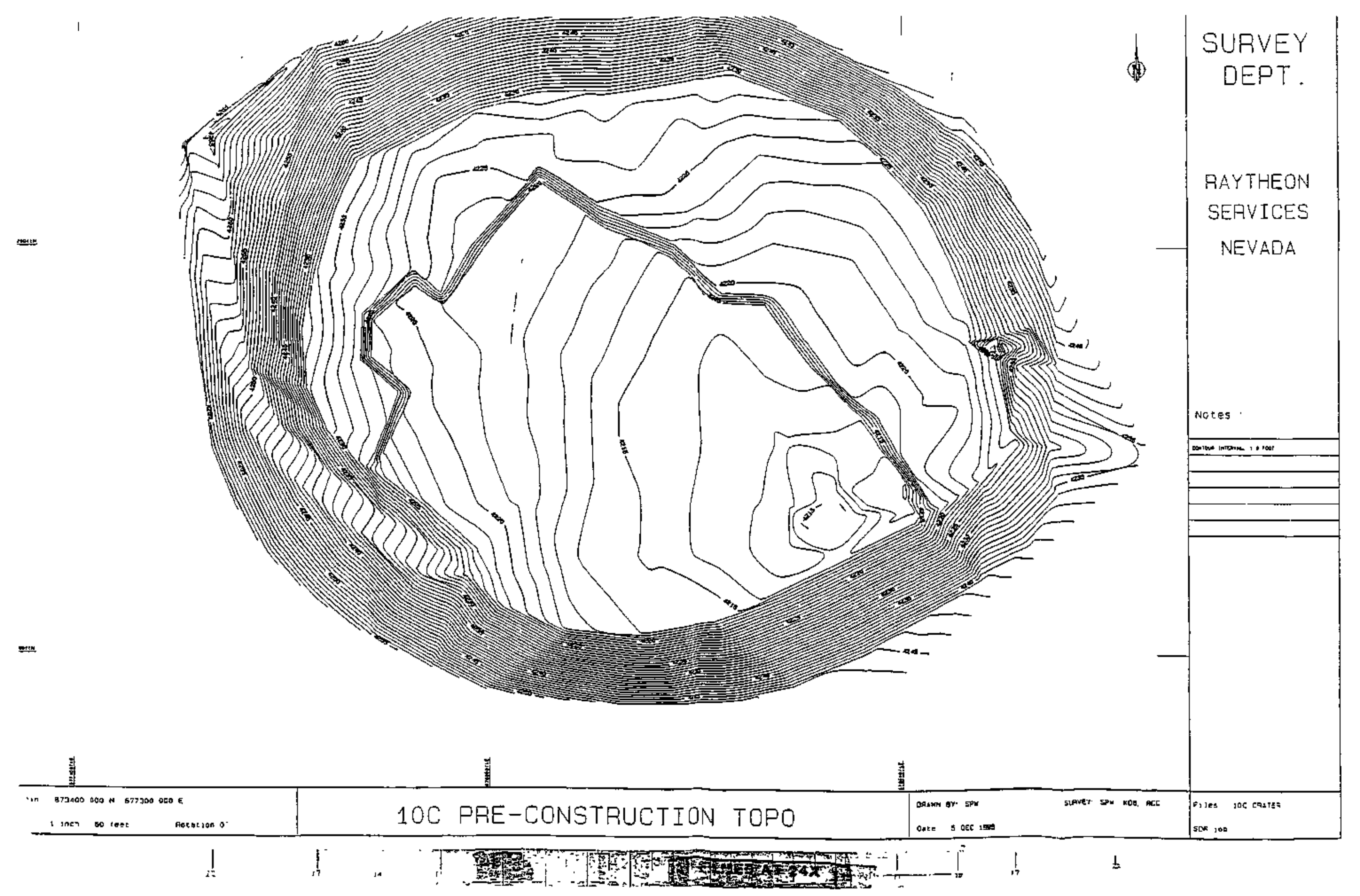




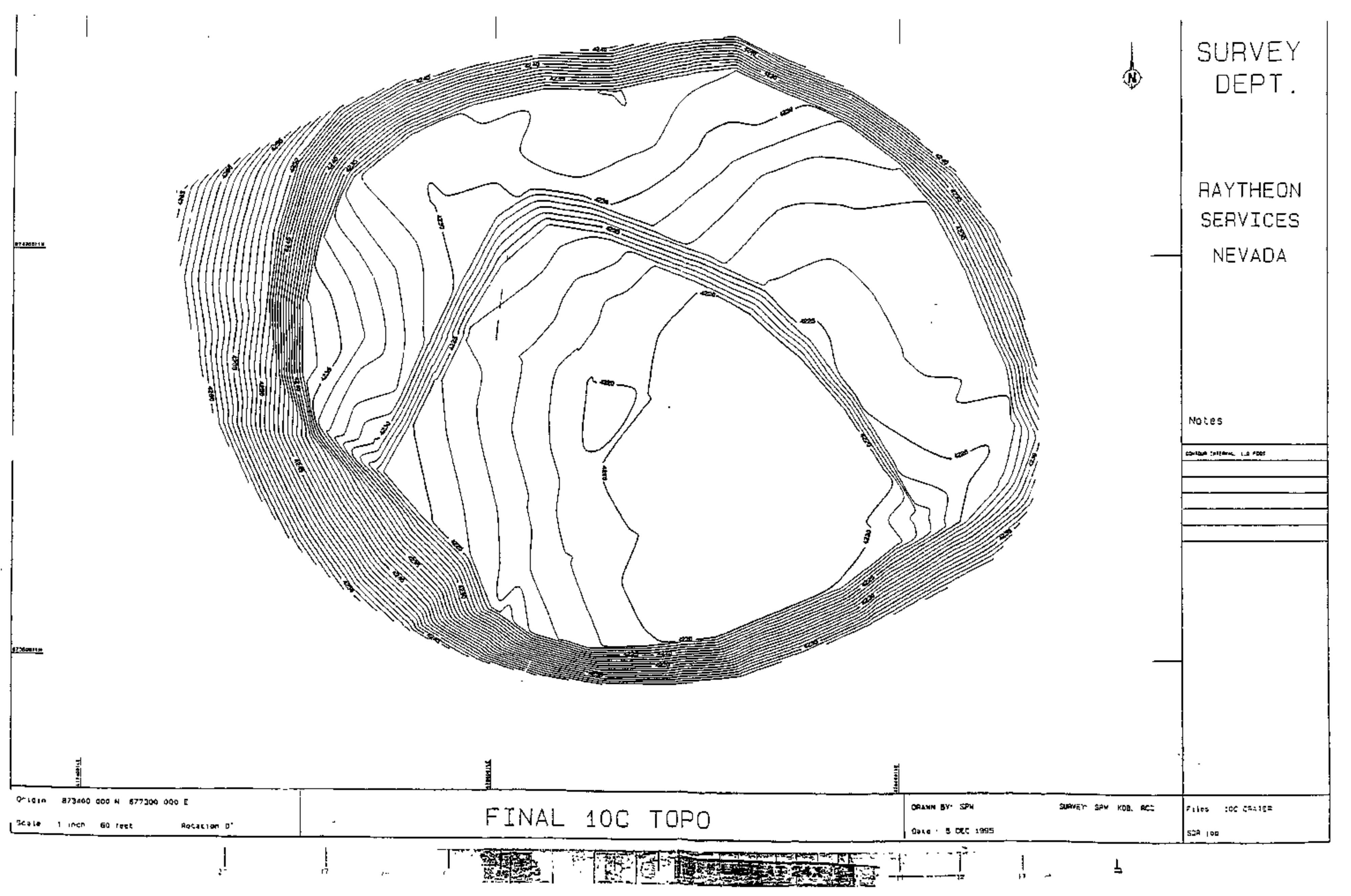


Appendix B

"Hydrologic/Hydraulic Assessment of the U10C Landfill in Area 9 of the Nevada Test Site (NTS)" 


\section{Bechtel Nevada}

Interoffice Memorandum

ID No: E110-KKV-96-005

Date: January 23,1996

To: $\quad$ L. S. Sygitowicz

From: K.K Van Cleave

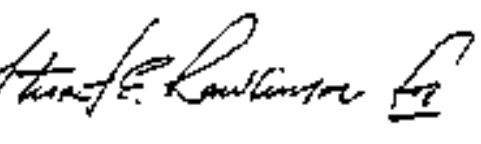

Subject HYDROLOGICAYDRAULIC ASSESSMENT OF THE UIOC LANDFILL IN AREA 9 OF THE NEVADA TEST SITE (NTS)

The Waste Management Program (WMP) requested a hydologichycirautic assessment of the U10C landill in Area 9 of the NTS, for compliance with new stats regulations for disposal sites. These segulations require: (1) an assessment of whether the landfill is in a 100-year flood hazard zone, and (2) protection from run-on associaled with a 25year flood event. This facility is not regulated under the Resoure Conservation and Recover Act, which mandates assessment of a 25-year, 24-hour flood event. Therefore, the run-on protection requirement can be met by evaluating $a^{t}$ least the 25 year, 6-hour frood. In this case, both requirenents were met by assesstribnt of the 100 year, 6-hout flood event.

The assessment was performed using methods described in the Clak tounty Fiegional Filood Control District (CCRFCD) Manual (1990) for both hydrologis and hydraulic analyses. The WMP requested that a detention system be evelbatee for run-on protection. Guidelines.for sizing "local minor detention systens" are estlined in the CCRFCD Manual (1990). information noeded for sizing inclustes:

- calculation of ortilet size;

- discharge rating for outler, and,

- storage routing.

Field investigations and calculations indicate tha: a detention systerr comprised of both the natural topography wast of Circle Road and the road grase vill provide approximately $4 \varepsilon$ acre-feet of storage volume (Attesthrieni 3 ). The rad grade will act as an earthen dam for the detention area, with outlei cortrol pravdes by wo existing culverts.

Outlet size is known; existing 24- and 36-inch CMP oulverts (one each) with release water from the detention area. Discharge rating date for both culvers were develaped using Flowwaster software (Attachment 2). Rating data were combined (both culverts 
L. S. Sygitowicz

January 23,1996

Page 2 of 2

will be discharging simultaneously) and used to perform storage routing with the HEC-1 model.

Results of the HEC-1 storage routing model indicate storage volume for 35 acre-feet of water is required (Attachment 3); therefore, the natural detention system provides sufficient storage volume. Also, in accordance with guidelines in the CCRFCD Manual (1990), the basin will completely drain in less than 24 hours (Attachment 4).

The HEC-1 storage routing model used the combined discharge rating data for both culverts to calculate a peak discharge of 37 cubic feet per second (Attacbment 3) from the detention systern. Flow released through the culverts witl become sheetflow. Sheetflow depth for the peak discharge is 0.03 feet (Attachment 5). This depth is less than the 1 foot reguiatory depth; therefore, the landiill is not within a 100-year flood hazard zone from sheetflow.

Existing topography will provide adequate sheettlow runoff protection for the landill;: additional drainage structures will not be required. The majority of the shestilow will come fiom noth-northwest of the landittl. This flow will be intercepted by an existing channel along the north side of the landfill, channelizing flow to the east, past the landiill. Sheettlow aiong the wast side of the landill will flow south-southeast past the landifill.

This hydrologichydraulic assessment has shown that the U10C tandfill is not within a regulatory 100-year flood hazard zone, and that flood protection structures will not be required at the landfill. Ал "existing" detention system will provide more than adequate storage volume for run-on protection. Existing culverts, if maintaired, will provide adequate outlet control and minimize sheetflow depths at the tandfill.

KKV:JJM:dm

Enclosures: as stated

ca: Cortespondence Control, wenc., M/S NLV008

D. L. Faster, w/o enc., WS 501

J. J. Mattick, wienc., WS $738 \div$

D. F. Merritt, w/o enc., MS 580

J. J. Mitler, w/enc., M/S 580 
Attachment 1.

Detention basin volume calcutations. 


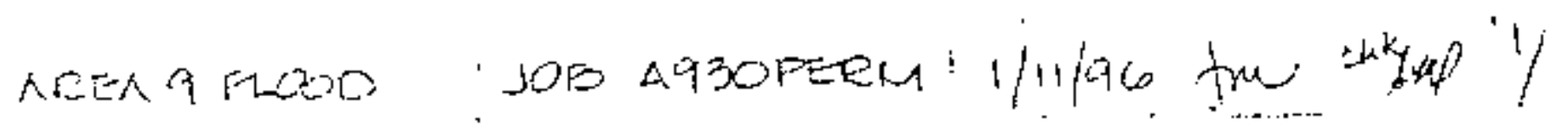

DETENTION OLSIN VOLDME CALCULATIONS: TOTAR OF 4 AREAS:

(1)

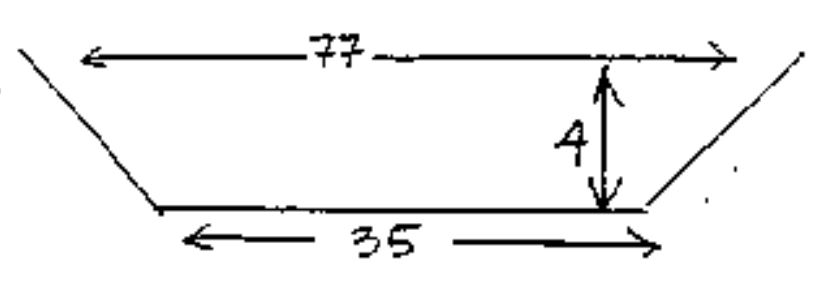

$$
\begin{aligned}
& a=77 \mathrm{FT} \\
& b=35 \mathrm{FT} \\
& h=4 \mathrm{~T}
\end{aligned}
$$

$$
\begin{aligned}
& A=\frac{(a+b) h}{2} \\
& A=\frac{(77+35)(4)}{2}=224 \mathrm{FT}^{2}
\end{aligned}
$$

$$
\begin{array}{ll}
\text { VOLUME }=A \div L \quad & A=224 \mathrm{FT}^{2} \\
L=170 \mathrm{FT}
\end{array}
$$

(2)

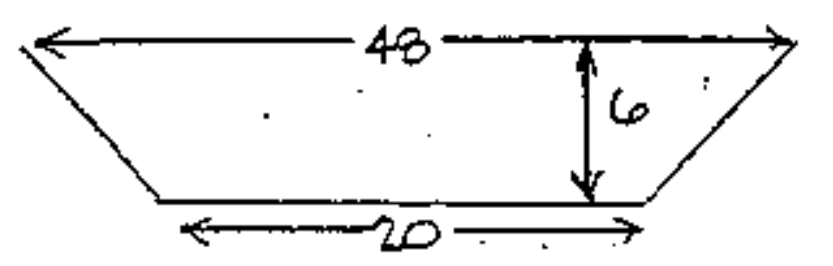

$$
\begin{aligned}
& a=48 \mathrm{FT} \\
& b=20 \mathrm{FT} \\
& h=6 \mathrm{FT}
\end{aligned}
$$

$$
\begin{aligned}
& A=\frac{(a+b) h}{2} \\
& A=\frac{(48+20)(6)}{2}=204 \mathrm{FT}^{2} \\
& \text { VOLUME }=A * L \quad A=204 \mathrm{FT}^{2} \\
& V_{2}=(204)(150)=30,600 \mathrm{FT}^{3}
\end{aligned}
$$




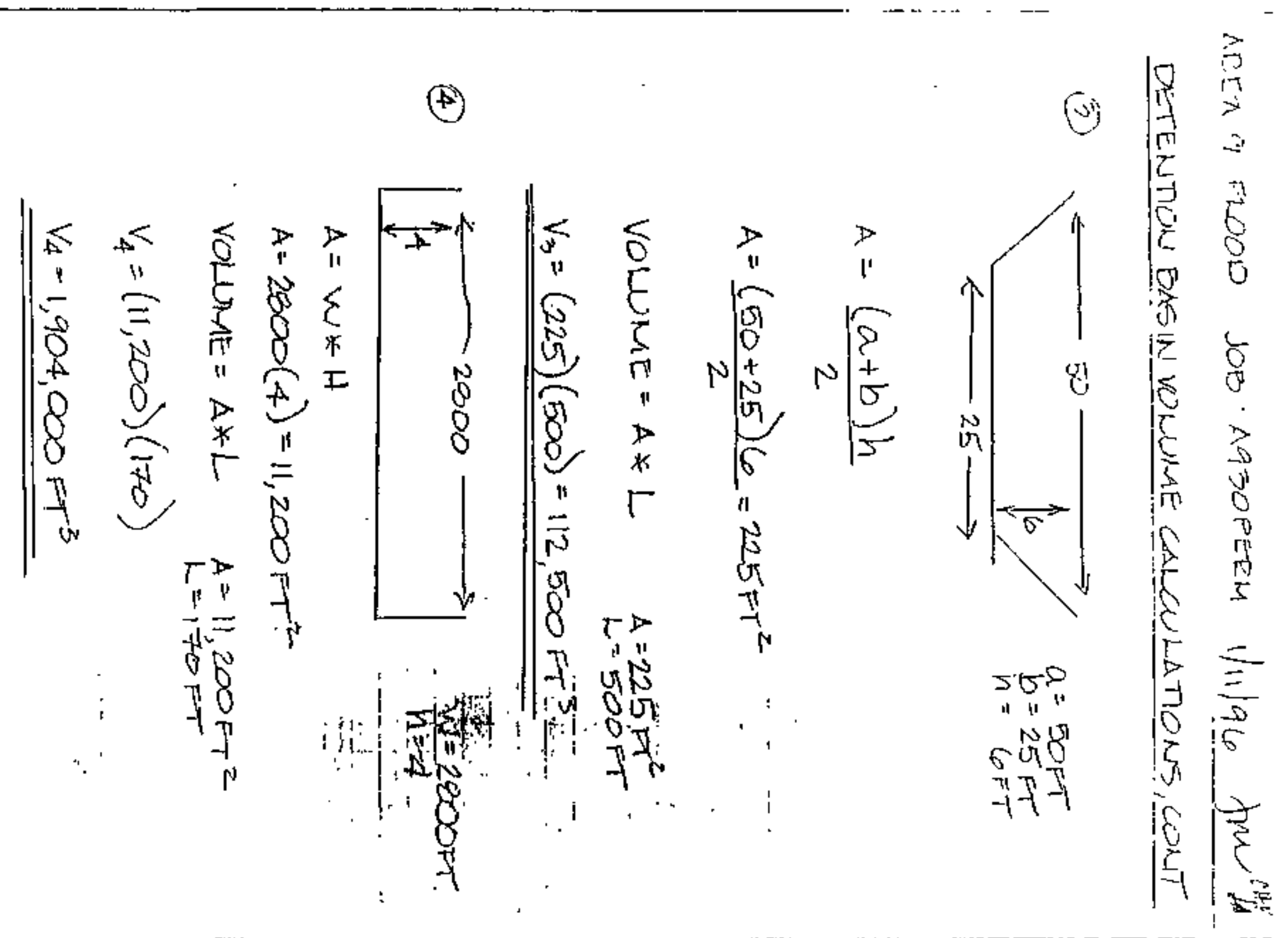




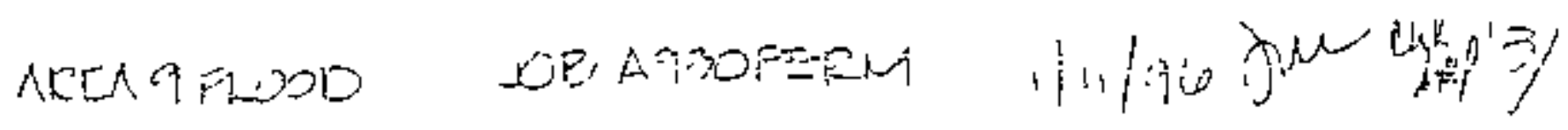

1 DETENTION BASIN VOLUME CALCULATORS, CONT

TOTAL VOLUME:

1

$$
V_{1}+V_{2}+V_{3}+V_{4}
$$

$$
\begin{aligned}
& V_{T}=38,080+39,600+112,500+1,904,000 \\
& V_{T}=2,085,180 \mathrm{FT}^{3} \\
& 2,085,180 \mathrm{FT}^{3}\left(\frac{2.296\left(10^{-5}\right) \Delta C E E S}{\mathrm{FT}^{2}}\right)=47.9 \mathrm{AC}-T \\
& V_{T}=47.9 \mathrm{ACRE}-\mathrm{FT}_{T}
\end{aligned}
$$


Attachrment 2.

Discharge rating calculations. 


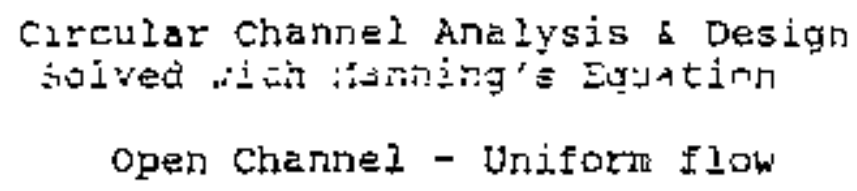

, Worksheet Name: DISCHaRGE RATINGS

Description: DISCHARGE RATINGS FOR 36" CMP

Solve For Actusl Discharge

Given Constant Data;

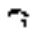

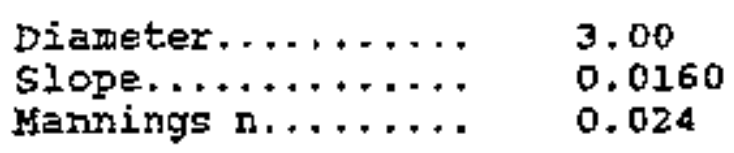

:- iable Input Data

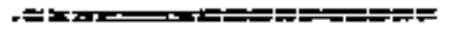
'spth

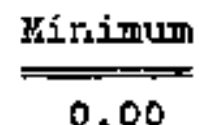

0.00 $\frac{\text { Maximum }}{3.00}$

Increment By 0.30

Open Channel Flow Module, Version 3.11 (c)

Haestad Kethods, Inc. * 37 Broolside Rd * teterbury, Ct 06708 


\begin{tabular}{|c|c|c|c|c|c|c|}
\hline \multirow[b]{2}{*}{$\begin{array}{l}\text { ¿ ame ter } \\
\text { s+. }\end{array}$} & \multirow[b]{2}{*}{$\begin{array}{l}\text { Channel } \\
\text { Slope } \\
\text { fŁ/tt }\end{array}$} & \multirow[b]{2}{*}{${ }^{M a n n i n g s}$} & \multirow[b]{2}{*}{$\begin{array}{c}\text { Discharg } \\
\text { CEs }\end{array}$} & \multicolumn{3}{|c|}{ 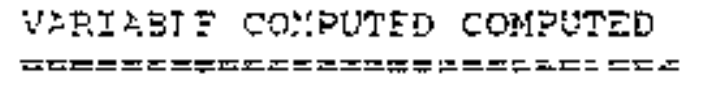 } \\
\hline & & & & Depth & $\begin{array}{c}\text { Velocity } \\
\text { fps }\end{array}$ & $\begin{array}{c}\text { Capacity } \\
\text { Full } \\
\text { Cf }\end{array}$ \\
\hline \multicolumn{7}{|c|}{ 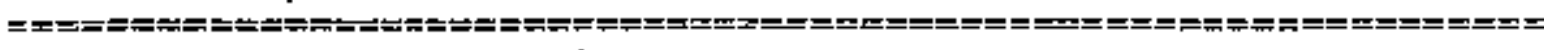 } \\
\hline \multicolumn{7}{|c|}{ :nable to compute this instarce. } \\
\hline .00 & 0.0160 & 0.024 & 0.95 & 0.30 & 2.59 & 45.70 \\
\hline 3. . & 0.0160 & 0.024 & 4.00 & 0.60 & 3.98 & 45.70 \\
\hline 3.00 & 0.0150 & 0.024 & 8.95 & 0.90 & 5.02 & 45.70 \\
\hline$=.00$ & 0.0160 & 0.024 & 15.40 & \pm .20 & 5.83 & 45.70 \\
\hline 3.00 & 0.0160 & 0.024 & 22.85 & 1.50 & 6.47 & 45.70 \\
\hline 2.00 & 0.0160 & 0.024 & 30.70 & 1.80 & 5.93 & 45.70 \\
\hline 3.00 & 0.0160 & 0.024 & 38.20 & 2.10 & 7.24 & 45,70 \\
\hline 3.00 & 0.0160 & 0.024 & 44.67 & 2.40 & 7.37 & 45.70 \\
\hline 3.00 & 0.0160 & 0.024 & 48.71 & 2.70 & 7.27 & 45.70 \\
\hline 3.00 & 0.0260 & 0.024 & 45.70 & 3.00 & 6.47 & 45.70 \\
\hline Un: & to compl & this $i$ & ance. & & & \\
\hline
\end{tabular}

Open Channed Flow wodule, Version 3.11 (c)

Haestad Nethods, Inc. * 37 Erookside Re * Waterbury, ct ofyos 


\section{Circular Channel Anelyszs a Design

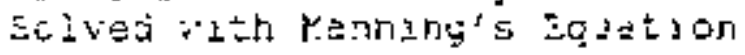 \\ open channel - Uniform flow}

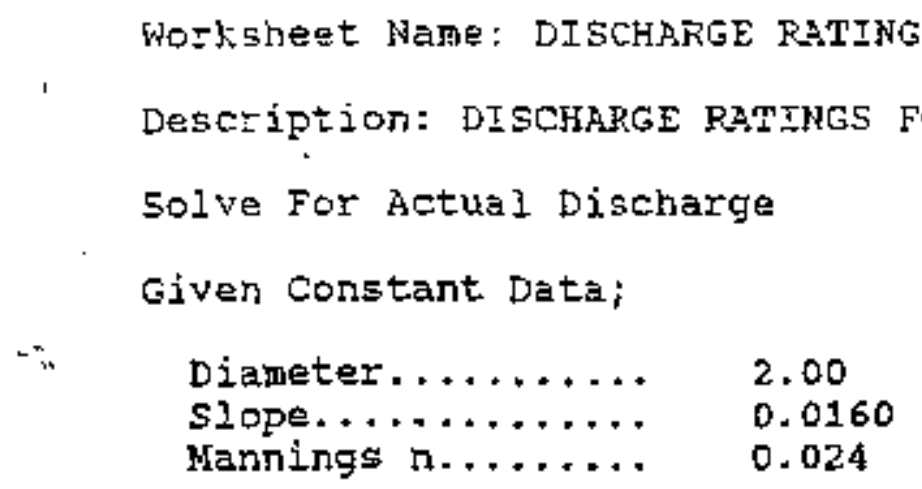

ariable Input Data

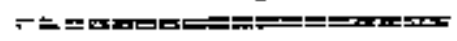

'эoth

\begin{tabular}{|c|c|c|}
\hline Minimum & Bayimum & Increnent By \\
\hline 0.00 & 2.00 & 0.20 \\
\hline
\end{tabular}




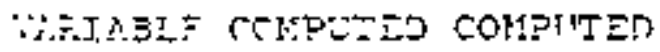

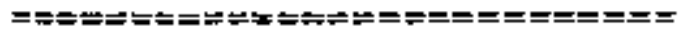

iamerer Chandel Mernings Discharge Depth Velocity Capacicy

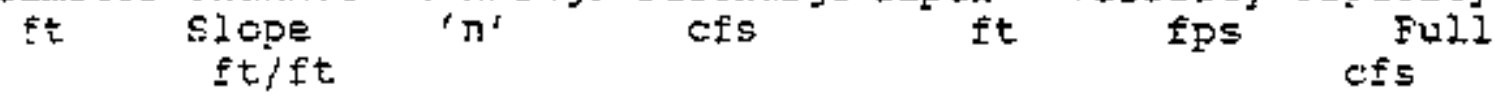

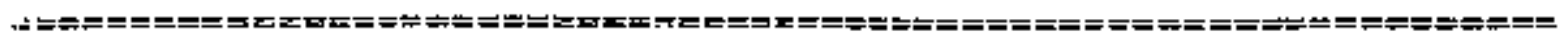

:nable to compute this instance.

000.0260 o. 0.32

$-100$

0.0160

0.024

1.36

0.20

1.98

15.50

$=00$

0.0160

0.024

3.04

0.40

3.03

25.50

2.00

0.024

5.22

3.83

35.50

2.00

0.024

7.75

4. 45

15.50

0.0160

0.024

10.41

0.80

4.93

15.50

2.00

0.024

12.98

5. 29

15.50

2.00

0.024

15.15

5. 52

15.50

0.0160

0.024

16.52

5.62

15.50

2.00

0.0150

0.024

15.50

5. 55

15.50

Unable to compute this instance.

4.93

15.50

Open Channel Flow Module, Version 3.11 (c)

Haestad Wethods, Inc. * 37 Brookside Rd * Waterbury, ct 06708 
Attachment 3 .

Storage routing calculations. 

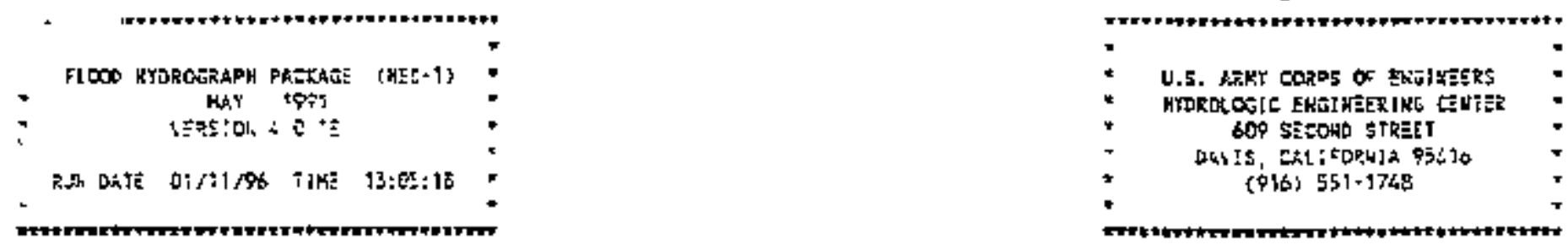

\begin{tabular}{|c|c|c|c|c|c|c|}
\hline$x$ & $x$ & $x+x \cos x$ & \multicolumn{2}{|c|}{$x \times x \times x$} & & 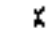 \\
\hline$x$ & $x$ & $x$ & $x$ & $x$ & & $x x$ \\
\hline$x$ & $x$ & $x$ & $x$ & & & $x$ \\
\hline \multicolumn{2}{|c|}{$\operatorname{xxax} x=$} & $x x x x$ & $x$ & & $2 x x=0 x$ & $x$ \\
\hline$x$ & $x$ & $x$ & $x$ & & & $x$ \\
\hline$x$ & $x$ & $x$ & $x$ & $x$ & & $x$ \\
\hline$x$ & $x$ & $\cos x \cos \alpha$ & & & & $20 x$ \\
\hline
\end{tabular}

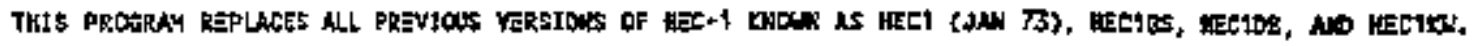

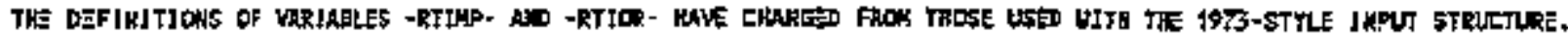

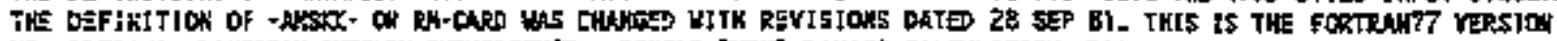

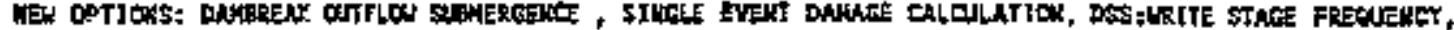

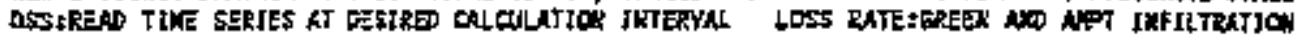

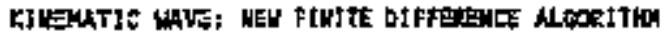

$105=1$ 11ENT PARE 1 .

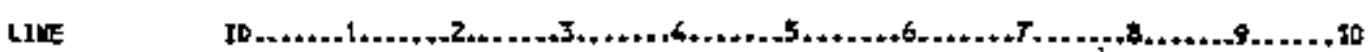

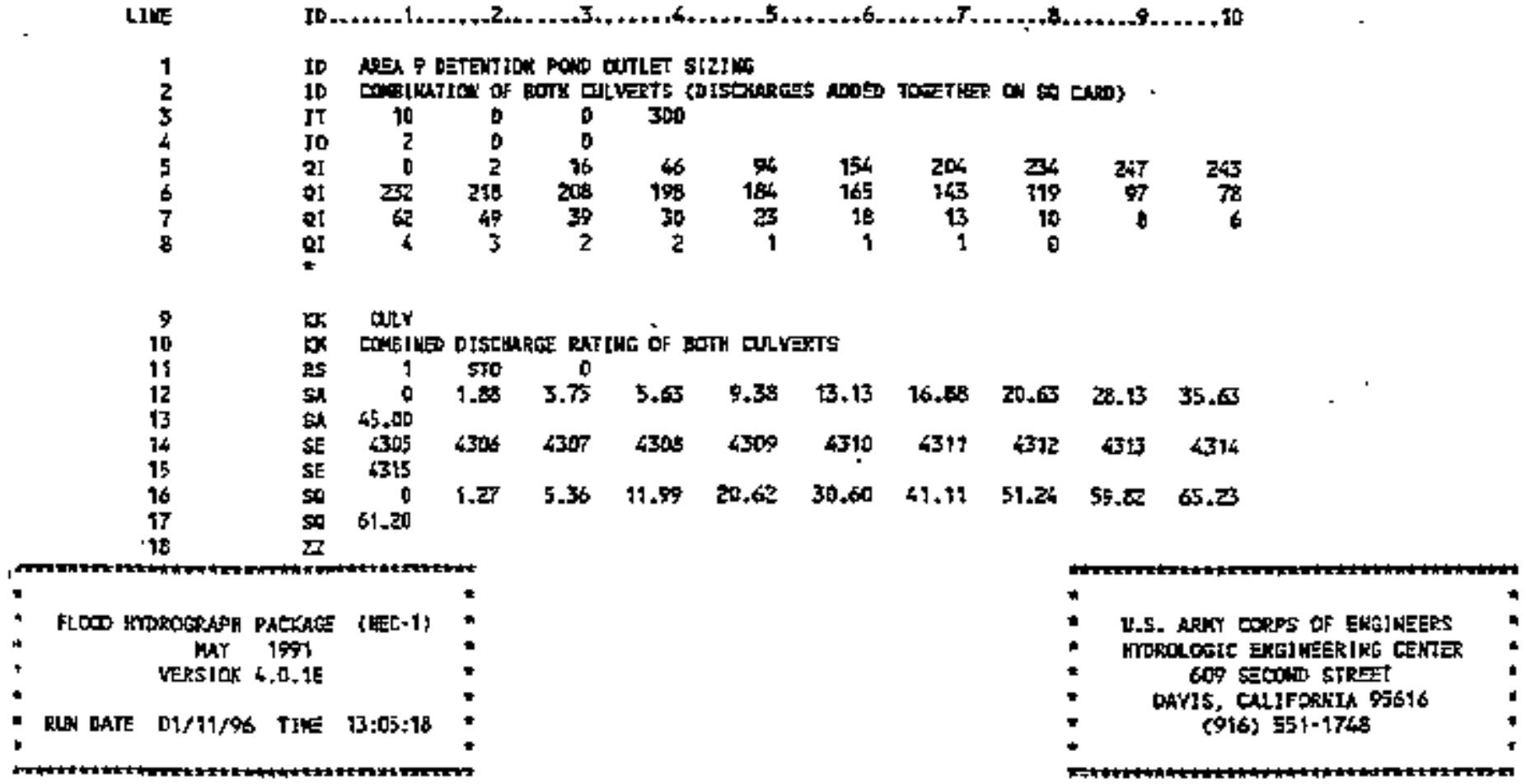

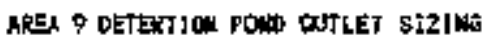

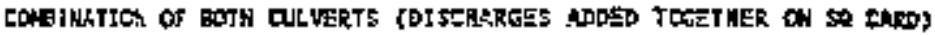

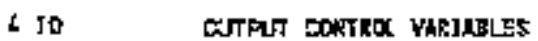




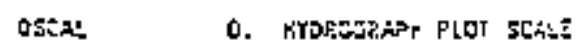

iT

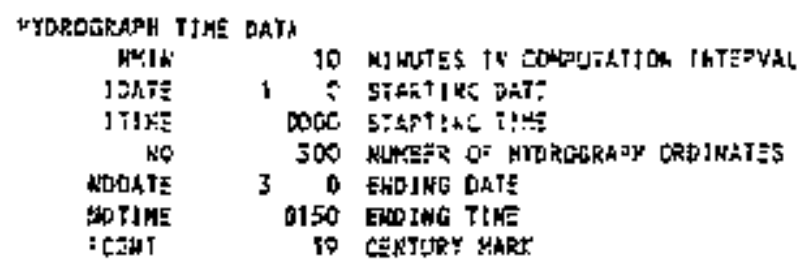

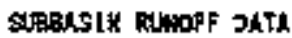

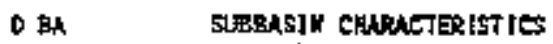

TNREA D.DO SUEBSEIU AREA

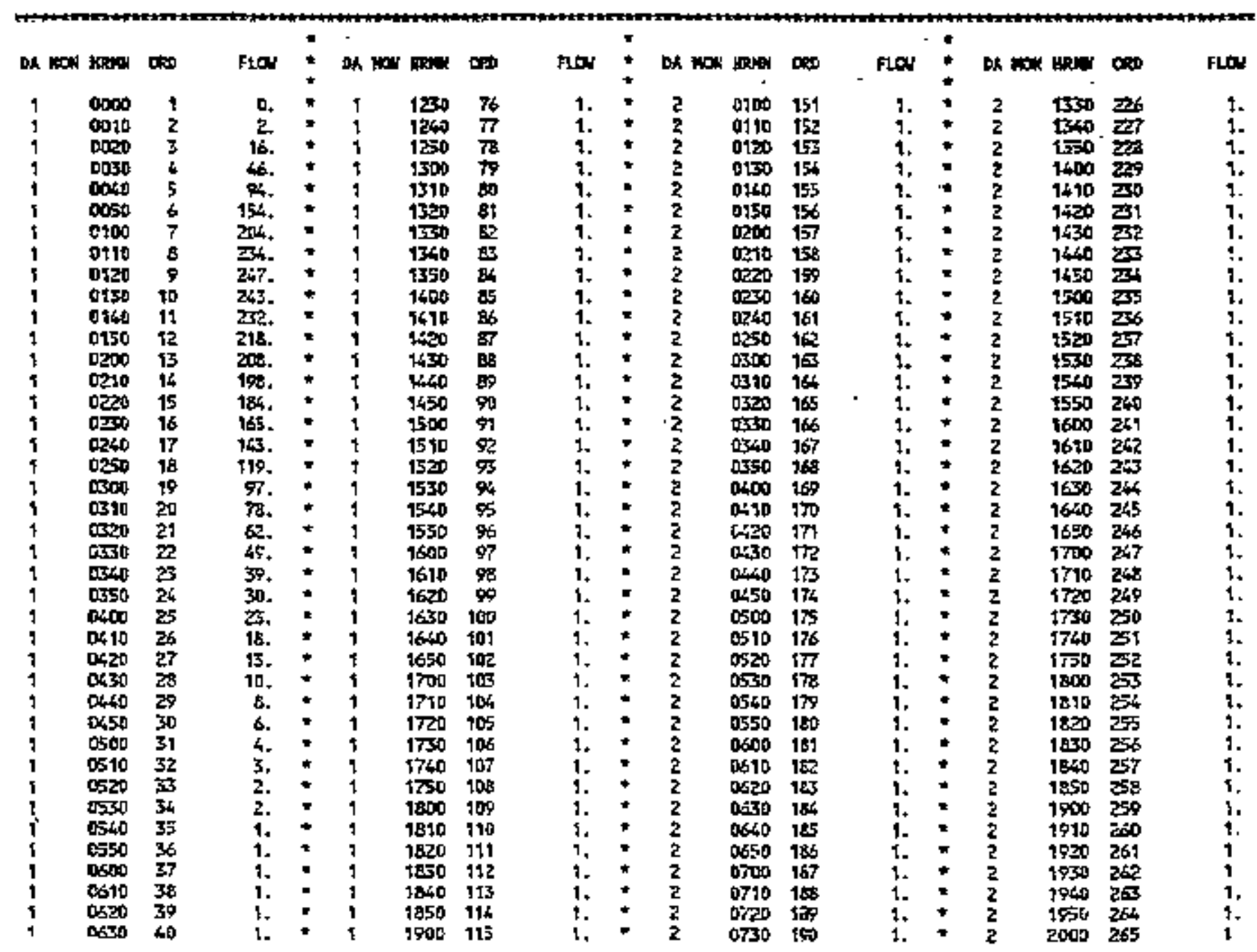




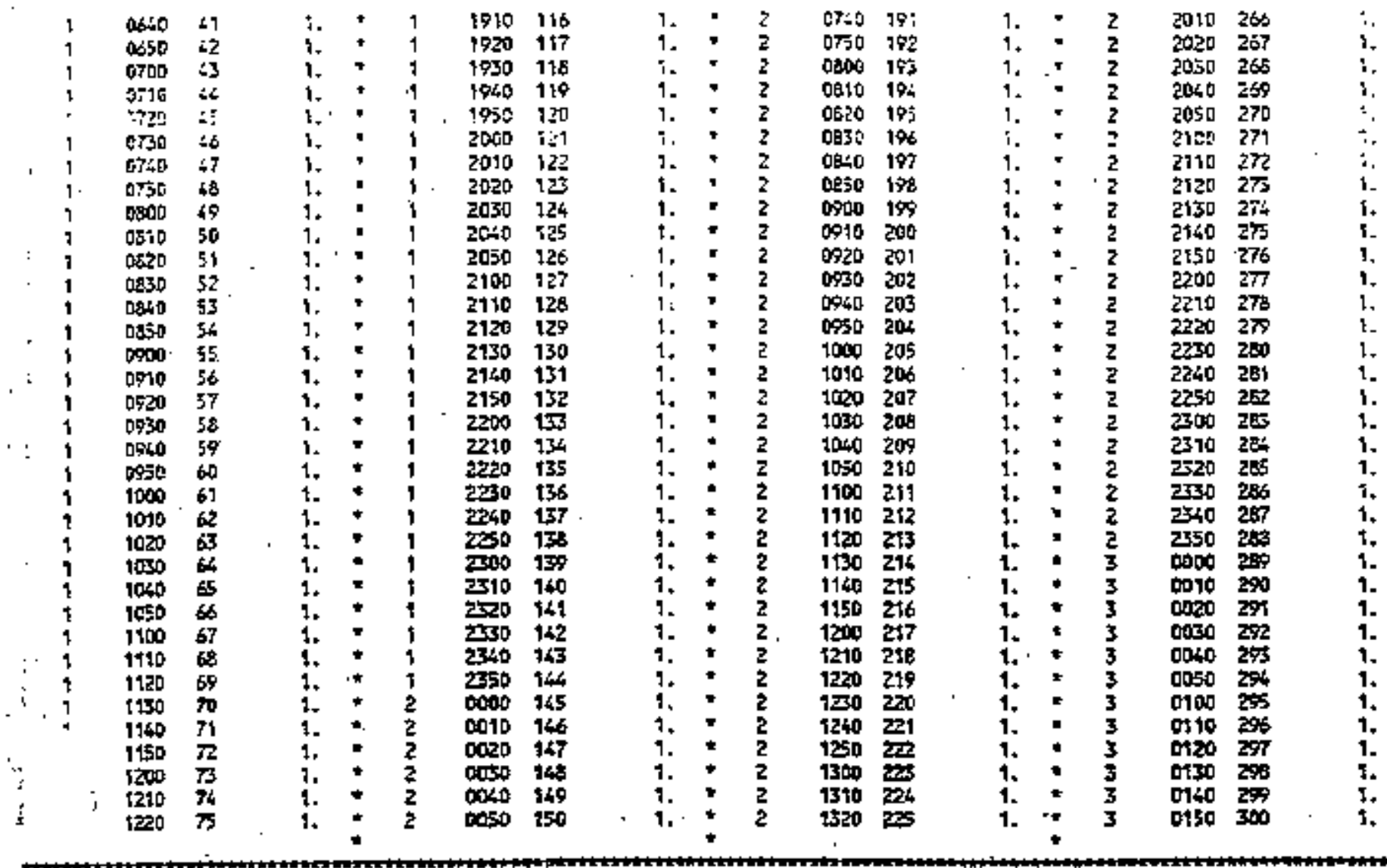

'PeAr FLO TINE

- (chs) (He)

267. $\quad 1.53$

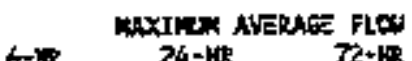

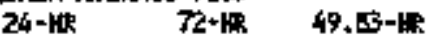

(CFS)

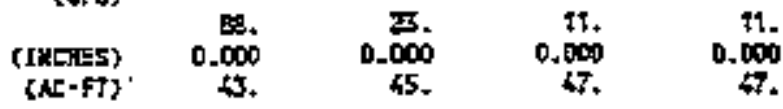

OALHATIV NREA $=.0 .00 \mathrm{FO}$ \%I

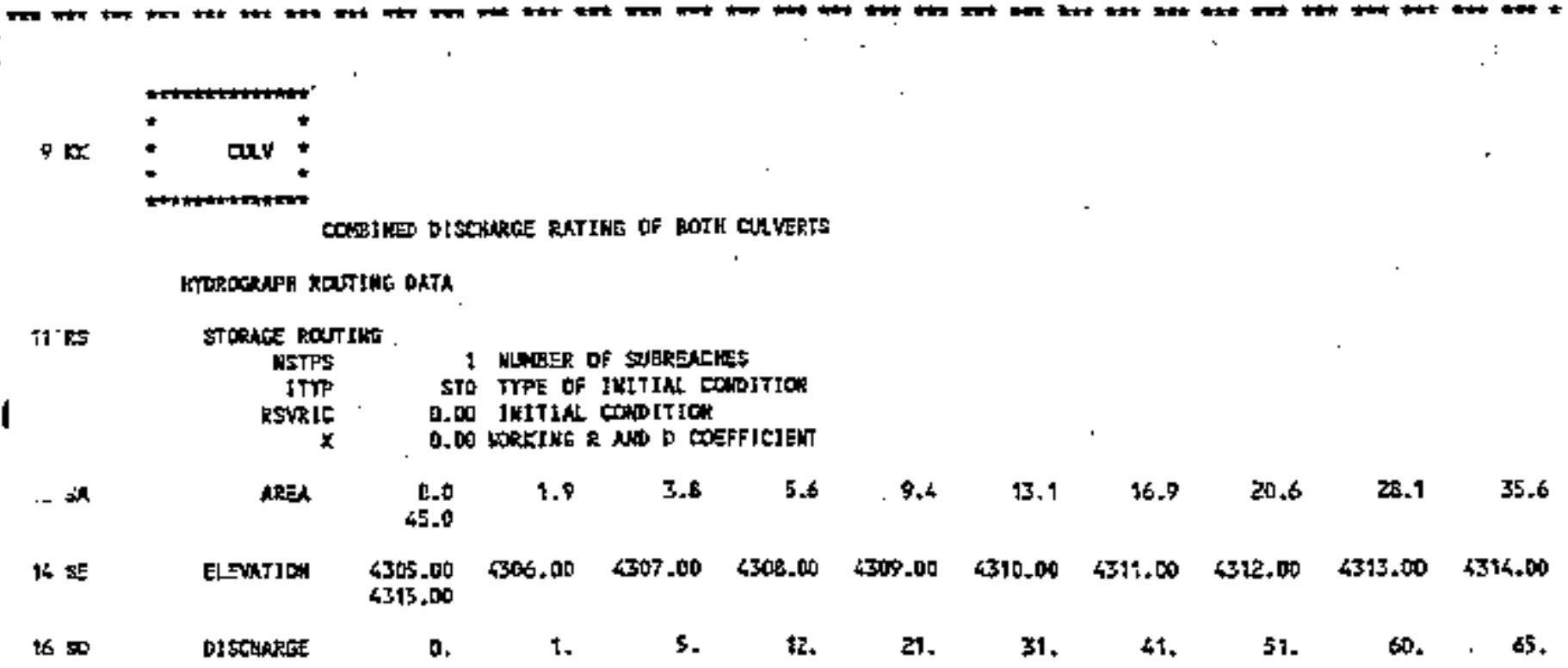

t6 5

D) SC4AREt

a. t.

5.

12.

ㄹ․

31.

$4 t$

51.

so.

65. 
GCHOUTEO STORAĞ-ELEVAIIN DATA

\begin{tabular}{|c|c|c|c|c|c|c|c|c|c|c|}
\hline 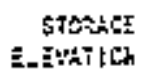 & כם & $\begin{array}{r}x .63 \\
-3 \sqrt{3} 0.00\end{array}$ & $\begin{array}{r}3+30 \\
-300^{2}+=0\end{array}$ & $\begin{array}{r}0.65 \\
4539.27\end{array}$ & $\begin{array}{r}5.47 \\
435 \% \text { on }\end{array}$ & $\begin{array}{r}26.57 \\
-31 . .98\end{array}$ & $\begin{array}{r}4 i .65 \\
+21^{2}-3 c\end{array}$ & $\begin{array}{r}60.36 \\
3:=.0 \%\end{array}$ & $\begin{array}{r}04.65 \\
435090\end{array}$ & $\begin{aligned} & 146.45 \\
= & 3 \% 4.75\end{aligned}$ \\
\hline $\begin{array}{r}\text { STORAEE } \\
\text { E1EVhTION }\end{array}$ & $\begin{array}{r}156.68 \\
4345.00\end{array}$ & & & & & & & & & \\
\hline
\end{tabular}

KTOROERAPH AI 5TKJ+ON GLLV

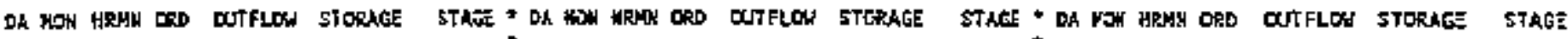

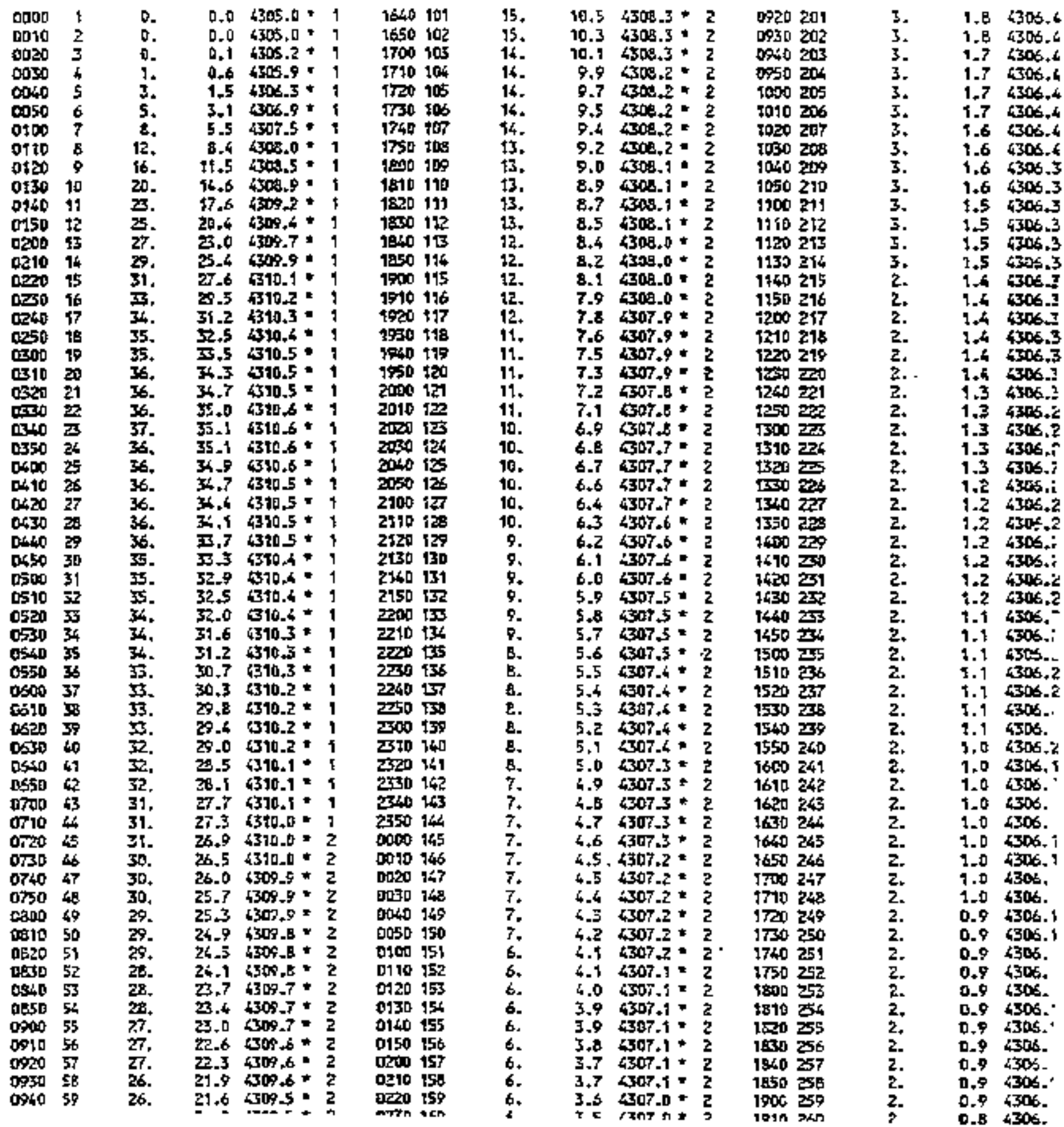




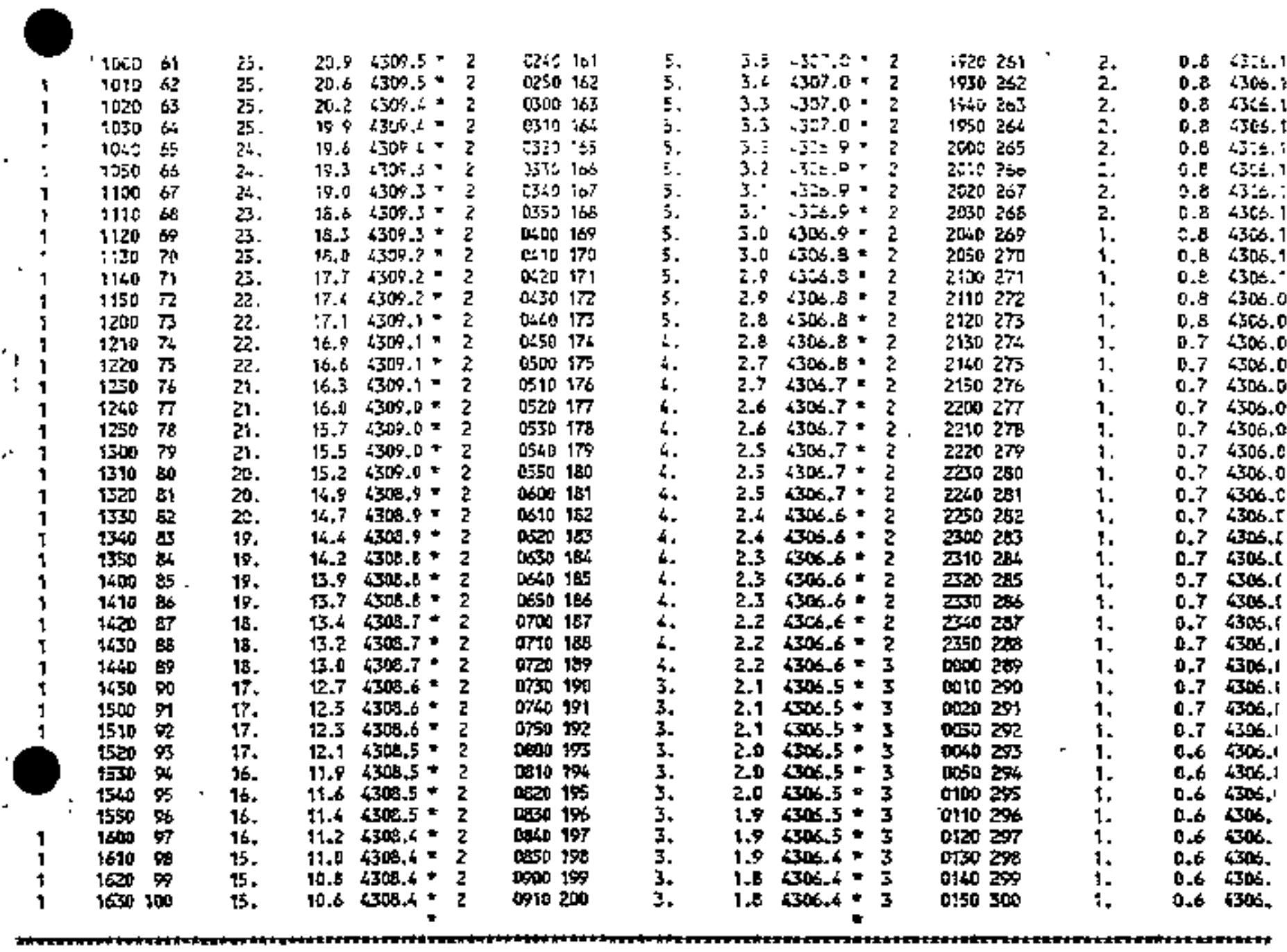

\begin{tabular}{|c|c|c|c|c|c|c|}
\hline \multirow{3}{*}{$\begin{array}{l}\text { PEH FLO } \\
+\quad \text { (CFS) }\end{array}$} & \multirow{3}{*}{$\begin{array}{l}\text { 기다 } \\
\text { [H⿻ }\end{array}$} & \multirow{3}{*}{ (ths) } & \multicolumn{4}{|c|}{ 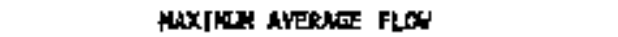 } \\
\hline & & & \multirow[t]{2}{*}{$G+\mathbf{B P}$} & \multirow[t]{2}{*}{$26-r$ R } & \multirow[t]{2}{*}{$\bar{R}+k R$} & \multirow[t]{2}{*}{$49.83 \times 14$} \\
\hline & & & & & & \\
\hline 37. & 3.67 & $\begin{array}{r}\text { (1nEhEs) } \\
\text { (Ne-ft) }\end{array}$ & $\begin{array}{l}33 . \\
0.000 \\
17 .\end{array}$ & $\begin{array}{l}21 . \\
0.000 \\
41 .\end{array}$ & $\frac{19 .}{0.000}$ & $\begin{array}{r}41 . \\
4.00 \\
4 .\end{array}$ \\
\hline PEAt STOKhHE & TIME & & & moxtrats av & as 5Tointes & \\
\hline & & & $6-9+10$ & $2 \alpha=12$ & TZ-HR & $49.85=153$ \\
\hline $\begin{array}{r}+(N-F T) \\
35 .\end{array}$ & $\begin{array}{l}\text { (FR) } \\
3.67\end{array}$ & & 31. & 17. & 9. & 9. \\
\hline PEAK, STIRE & INAF & & & 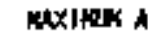 & ATAC & \\
\hline & & & 6 - & $24-4 \pi$ & $72-11 R$ & $49.83-\mathrm{FR}^{2}$ \\
\hline $\begin{array}{r}\text { (FEET) } \\
\text { (310.56 }\end{array}$ & $\begin{array}{l}\text { (ARP) } \\
3.57\end{array}$ & & $4310.2 z$ & 4305.89 & 4507.57 & 4307.57 \\
\hline & & 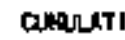 & E AREA $=$ & $0.00 \sin x$ & & \\
\hline
\end{tabular}

RUWOFF DIPOART

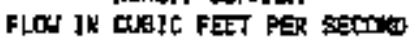

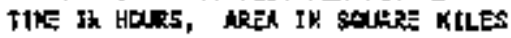

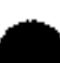

PER THE OF
CPERTION STATIOH FLO PENK

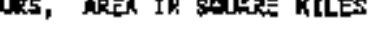

CPERTION Sikitan

FLOA PEN

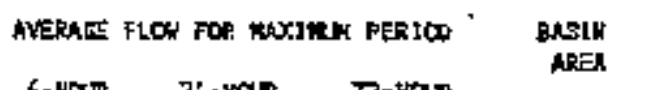

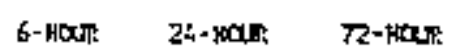

khXipy tIkE of STAFE MX STACE
HTOROARAPH RT

सDEF to

\begin{tabular}{|c|c|c|c|c|c|c|}
\hline 매난 & 247. & $1+3$ & 요. & ]3. & iท. & 0.00 \\
\hline dILV & 37. & 3.67 & 35. & 21 . & 11. & D.tל心) \\
\hline
\end{tabular}
alv 37. 3.67
35. 21
11. D.tำ

$4310.56 \quad 3.67$ 
Attachment 4.

Drainage time calculations. 


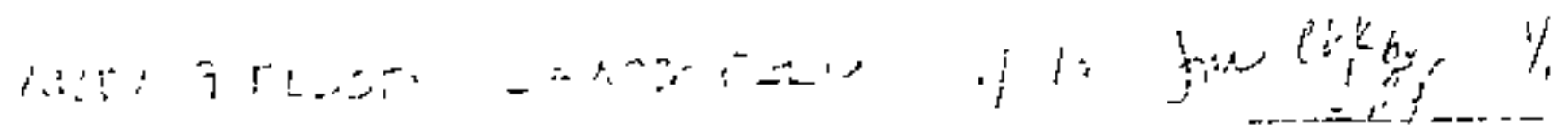

TIME TO DRAN DETELTION BASIN

$$
\begin{aligned}
& 35 \text { ACREFT }\left(\frac{4356\left(10^{4}\right) \mathrm{FT}^{2}}{\text { ACRE }}\right)=1,524,600 \mathrm{Ft}
\end{aligned}
$$

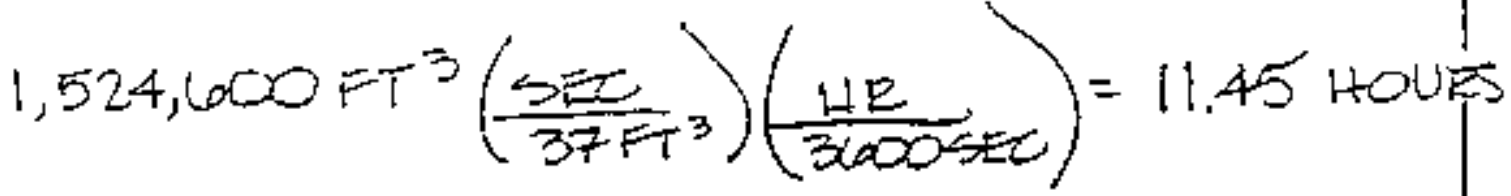


Attachment 5 .

Sheetflow depth calculations. 


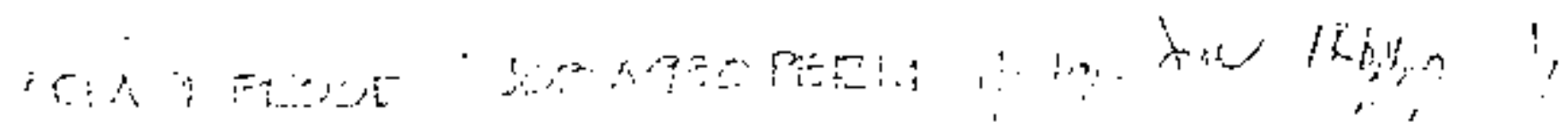

SHEETFLOW DEPTH CALCULATIONA

$$
\begin{aligned}
& d=\left[\frac{Q n}{(1.49)\left(5^{1 / 2}\right)(w)}\right]^{3 / 5} \\
& Q_{\text {culv }}=37 \mathrm{cfs} \\
& n=0.04 \\
& S=0.016 \mathrm{FT} / \mathrm{FT} \\
& w=3500 \mathrm{FT} \\
& d_{w L Y}=\left[\frac{37(0.04)}{(1.49)(0.016)^{1 / 2}(3600)}\right]^{3 / 5} \\
& \text { dour }=0.03 \mathrm{FT}
\end{aligned}
$$




\section{Appendix D}

"10C Crater, Landfill Closure" - Soil Testing Data 
september 21,1994

NTS : QEI : HTL : 101-94

Richard ziegenbein

Raytheon Services Nevada

Post office Box $329, \mathrm{M} / \mathrm{S} 608$

Mercury, NV. 89023

\section{OC CRATER, LANDEILL CLOSURE}

As requested, the Materials Testing Laboratory performed Angle of Repose, Atterberg Iimits, Consolidation (BTSE), Direct shear (4 points), Gradation, Hydrometer, Moisture, Percent Porosity, Permability, Modified Proctor, soil classification, specific Gravity, and Unic weight on the bag samples taken in four areas (see location sketch) designated by Julie sorola from Engineering. Samples were remolded to about 958 of Modified Proctor at optimum moistuze for the consolidation, Direct shear, and Permability tests. All four Atterberg limits were too sandy to Iun the plastic linit and pre sample was too sandy to run the liquid limit between 20 \& 30 blows as per ASTM requirements. All four Atterberg linits are listed as non-plastic. All tests are listed in the Appendix.

If you have any further guestions concerning this matier or need additional tests, please contact Mr. Dale Herrington at 295-6813.

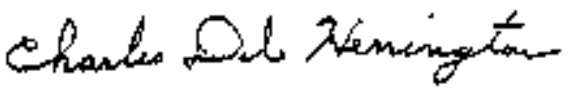

Charles Dale Herrington

Senior specialist

Enclosures

As Stated

be: N. Rohach, w/o encl.

V. Thumuala, w/encl.

D. HerIington, w/encl.

CHRON Files

MTL Files, w/encl. (00808) 
APPENDIX

1. LOCATION SKETCH

2. ANGLE OF REPOSE

3. LIQUID LIMIT, PLASTIC LIMIT, AND PLASTIC INDEX

4. CONSOLIDATION

5. CONSOLIDATION GRAPES

6. DIRECT SEEAR

7. DIRECT SHEAR GRAPAS

8. GRADATION, MOISTURE, UNIT WEIGET, \& POROSITY

9. GYDROHE'TER - TAELE 1

10. EYDRONETER - TAELE 2

11. HYDROMETER - TABLE 3

12. HYDROMETER - TABLE 4

I3. HYDROMETER GRAPRS

14. PERMABIIITY

15. PROCTOR (MODIFIED)

16. SOIUS CLASSIFICATION CURVE

27. SPECIFIC GRAVITY 


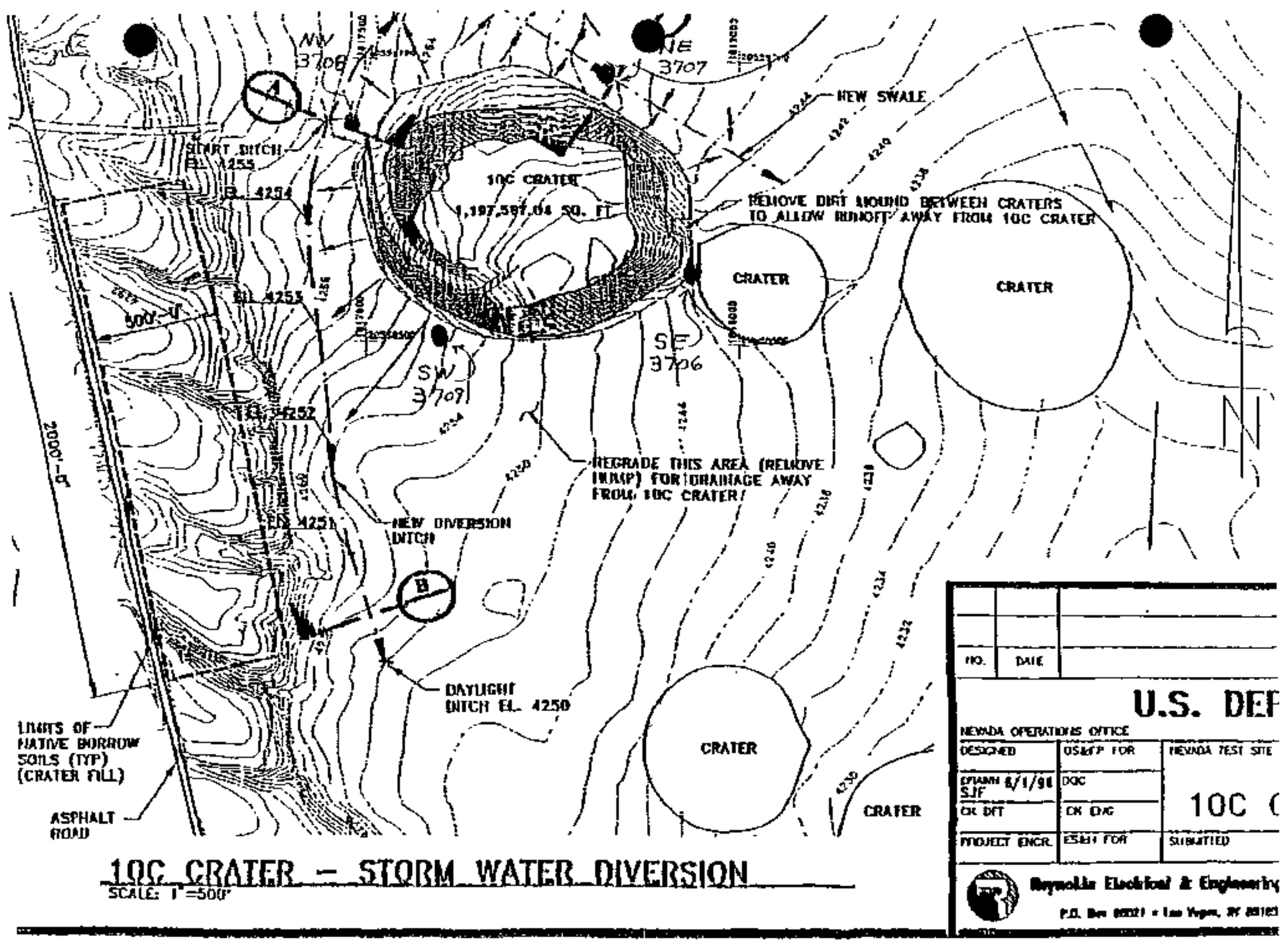




\section{Raytheon Services Nevada MATERIALS TESTING LABORATORY NEVADA TEST SITE}

\section{ANGLE OF REPOSE}

\begin{tabular}{|c|c|c|c|}
\hline Project: & 10C CRATER, LANDFIL CLOSURE & RSN ID \#: & 00808 \\
\hline Requestor: & R. ZIEGENBEIN & Organizatron: & RSN \\
\hline Tested byt & R. STROTE & Test date: & $08 / 30 / 94$ \\
\hline Checked by: & D. HERRINGTON $O Q$ & Check date: & $9-20-94$ \\
\hline
\end{tabular}

\begin{tabular}{|r|r|}
\multicolumn{1}{l}{$\begin{array}{l}\text { Lab } \\
\text { \# }\end{array}$} & $\begin{array}{c}\text { ANGLE OF } \\
\text { REFOSE } \\
\text { (Degrees) }\end{array}$ \\
\hline 3706 & 28.0 \\
\hline 3707 & 25.5 \\
\hline 3708 & 26.0 \\
\hline 3709 & 27.5 \\
\hline
\end{tabular}

NO CALIERATED EOUIPMENT USED

Hemarks: 


\begin{tabular}{|c|c|c|c|c|c|}
\hline $\begin{array}{c}\text { Liquid Lrmit } \\
\text { Plastic Limit } \\
\text { ASTM D-4318-84 }\end{array}$ & $\begin{array}{r}\text { Raytheor } \\
\text { MATERIALS } \\
\text { MER }\end{array}$ & $\begin{array}{l}\text { Sërvices } \\
\text { TESTING LABO } \\
\text { P. O, \$OX 398 } \\
\text { RCUAY NV. 8902 }\end{array}$ & $\begin{array}{l}\text { Nevada : } \\
\text { ORATORY }\end{array}$ & $\begin{array}{l}\text { IDH } \\
\text { DATE TYFED } \\
\text { PAGE }\end{array}$ & $\frac{00908}{\frac{09 / 13 / 94}{1 \text { of } t}}$ \\
\hline Requisted by R, ZIEGENBEIN & User/agency & $\mathrm{FSN}$ & & Matertal & EXISTING \\
\hline Projed 10C CAATER, LAND & FILL CLOSUAE & Tesțt Loctation & ARE & EA 10 & \\
\hline Tested by D. ANDERSDN & Date Tested & $05 / 12 / 94$ & Checked by & D. HERAINGTON & $x, 1,2$ \\
\hline Laboratory No. & 3706 & 3707 & 3708 & 3709 & N/A \\
\hline No. of Blows & 28 & 27 & 12 & 25 & \\
\hline Correction Factor & 1.014 & 1.009 & 0.916 & 1,000 & \\
\hline Adjusted Molsture Content \% & $20.6 \%$ & $23.2 \%$ & N/A & $22.5 \%$ & \\
\hline Tare No. & 4 & 20 & 9 & 101 & \\
\hline 1. Wh. Wet Soil + Tare: & 13.992 & 12.019 & 15.709 & +5.936 & \\
\hline 2. Wt. Dry Doil + Tare: & 11.883 & 50.077 & $13.17 \uparrow$ & 13294 & \\
\hline 3. Wt. of Moisture: & 2.109 & 1,942 & 2.538 & $2.642 !$ & \\
\hline 4. Wht of Tare: & 1.509 & 1.634 & 1.638 & 1.570 & \\
\hline 5. Wt of Dry Sail: & 10.3741 & 8.443 & 11.533 & 11.724 & \\
\hline 6. Moisture Content \%: & $20,3 \% 1$ & $23.0 \%$ & $22.0 \%$ & $22.5 \%$ & \\
\hline Laboratory No. & 3705 & 3707 & 3708 & 3709 & $\mathrm{~N} / \mathrm{A}$ \\
\hline Tare No. & $N / A$ & $\mathrm{~N} / \mathrm{A}$ & $\mathrm{N} / \mathrm{A}$ & N/A & $N / A$ \\
\hline 1. Wh. Wet Soif + Tare: & N/A & N/A & N/A & $N / A$ & $N / A$ \\
\hline 2. Wh. Dry Doil + Tare: & $N / A$ & $N / A$ & $N / A$ & $\mathrm{~N} / \mathrm{A}$ & $N / A$ \\
\hline 3. Wh of Molsture: & $\mathrm{N} / \mathrm{A}$ & $N / A$ & $\mathrm{~N} / \mathrm{A}$ & $N / A$ & N/A \\
\hline 4. Wh of Tare: & $N / A$ & $N / A$ & $N / A$ & $N / A$ & $N / A$ \\
\hline 5. Wht of Dry Soil: & N/A & N/A & $N / A$ & $N / A$ & N/A \\
\hline 6. Masture Content \%: & $\mathrm{N} / \mathrm{A}$ & $N / A$ & $N / A$ & N/A & $N / A$ \\
\hline Laboratary No. & 3706 & 3707 & 3708 & 3709 & $N / A$ \\
\hline Adjusted Liguld Limi \% & $20,6 \%$ & $23.2 \%$ & N/A & $22.5 \%$ & $N / A$ \\
\hline Plastic_Lmit \% & N/A & $\mathrm{N} / \mathrm{A}$ & $\mathrm{N} / \mathrm{A}$ & N/A & $\mathrm{N} / \mathrm{A}$ \\
\hline Plastie Index & NON PLASTIE & NON PLASTIE & NON PLASTIC & NON PLASTIE & N/A \\
\hline
\end{tabular}

Requisted by R, ZJEGENBEIN

LIQUID LIMIT

1. wh. Wet Soil + Tare:

2. Wt. Dry Doil + Tare:

3. Wht of Moisture:

4. Wit of Tare:

5. Wh of Dry Sail:

Projecl $10 \mathrm{C}$ CRATER LANOFIL CLOSUAE

Tested by D.ANDERSON Date Tested

Plastic Limit

28

$20.6 \%$

4

11.883

2.109

$20.3 \%$
P. On BOX 328

$\mathrm{FSN}$

AFEA 10

Material EXISTING 
CONSOLDATION

CF SOILS

ASTM D2435-90
Raytheon Services Nevada MATERIALS TESTING LABORATORY NEVADA TEST SITE \begin{tabular}{ll}
\hline \hline Project: & IOC CRATER, LANDFIL CLOSURE \\
Requestor: & F. ZIEGENESIN \\
Location: & AREA 10 \\
Tested by: & O. ANDERSON \\
\hline \hline
\end{tabular}

MOISTUAE CONTENT
ASN ID : 00800

Organizallon: RSN

Sample: S.E. EXISTING

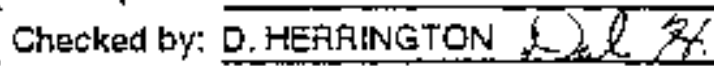

\begin{tabular}{|c|c|c|c|c|c|c|c|}
\hline \multirow[b]{2}{*}{ LAB \# } & \multicolumn{3}{|c|}{ MOISTUFE CONTENT } & \multicolumn{2}{|c|}{ (BEFORE) } & \multirow[b]{2}{*}{ DEY SORL } & \multirow[b]{2}{*}{ MOISTURE T: } \\
\hline & TARE $\#$ & WET Wr: & DFY WT. & WATER & TARE WT: & & \\
\hline 3706 & 5 & 329.90 & 310,0 & 19.10 & 149.70 & 161.10 & $11.9 \mathrm{t}$ \\
\hline
\end{tabular}

\begin{tabular}{|c|c|c|c|c|c|c|c|}
\hline$L A B \#$ & TARE \# & WET WT. & DRY WT. & WATER & TARE WT & DRY SOIL & MOISTUSRE \\
\hline 3706 & 6 & 316.40 & 292.90 & m.sol & 156.70 & 136,90 & $17.3^{\circ}$ \\
\hline
\end{tabular}

RHNG SAMPLE WT:(gID)

RING =

DLAMETER

SAMPIE WETUNIT WEGTF?:

\section{LOAD}

DATE TTME

$\mathrm{NSP}$

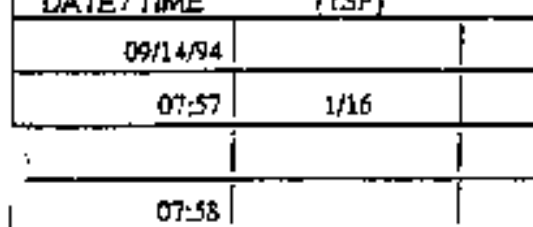
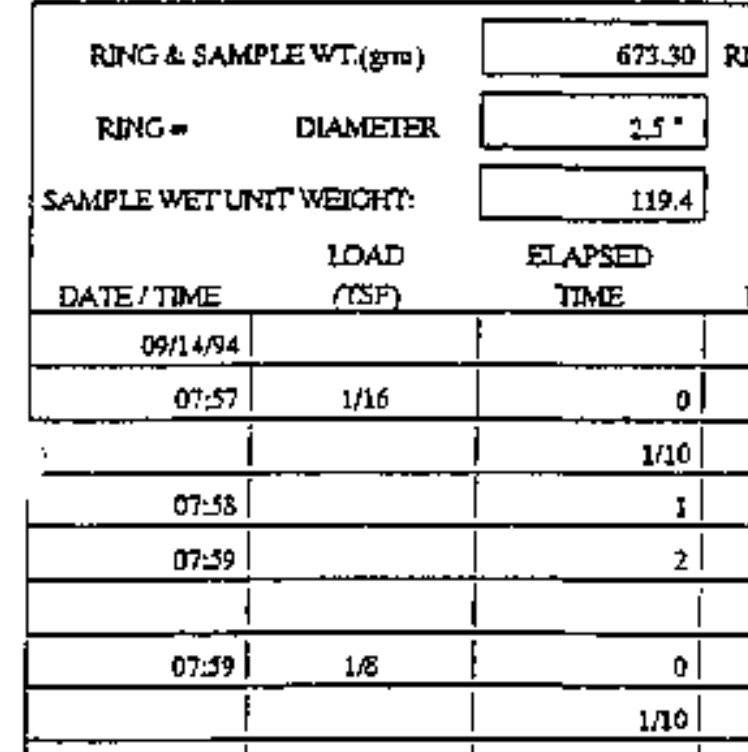

TIME

THME

i

DLAL

$\sin 0.10$ WEGHT OE SOIL IN RING (gIm)

0.034085462

VOLMME (iT) $\left(H T=10^{\circ}\right)$

SAMPLEDRY UNTT WEGGT:

REMPNCS

LOAD

ELAPSED TSF TME

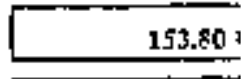

153.803

0.0028407052

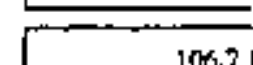

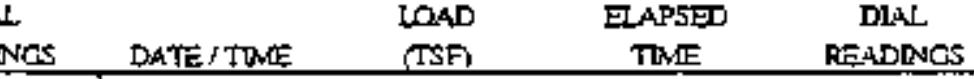

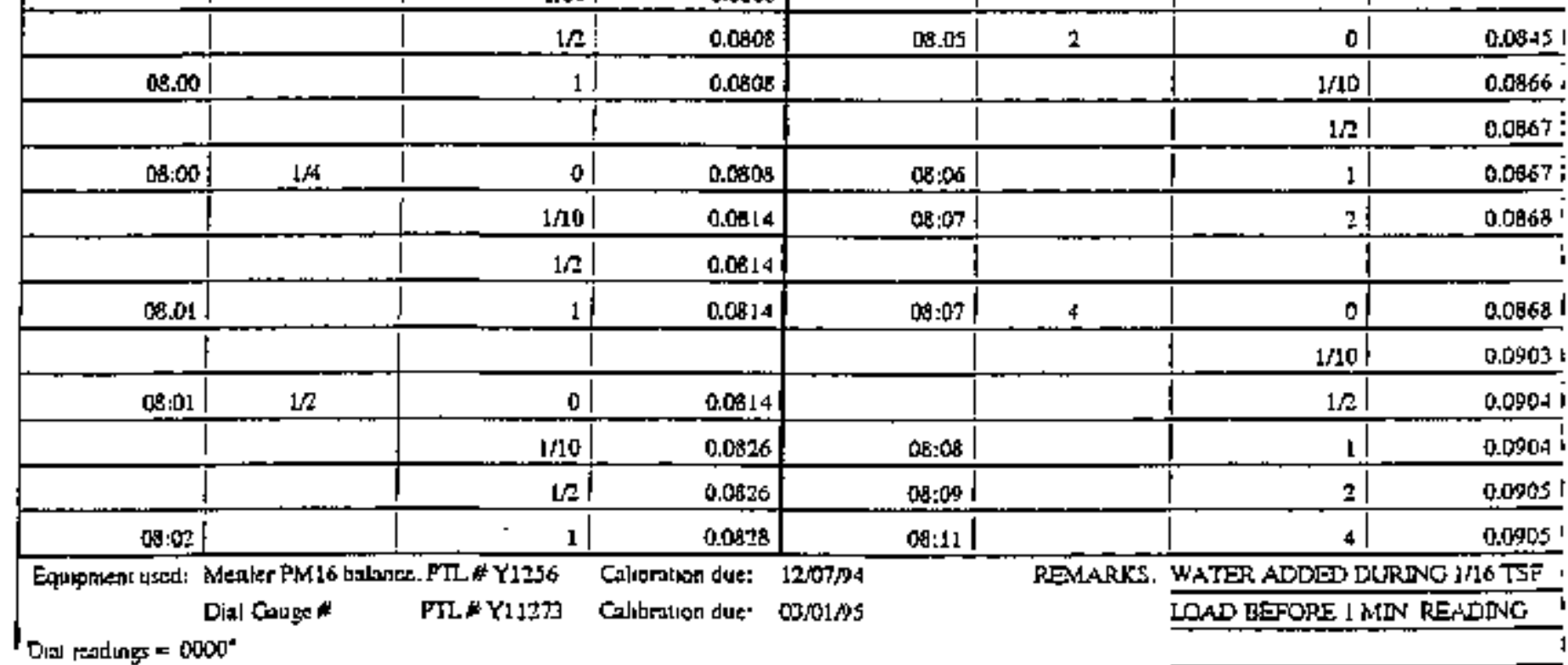

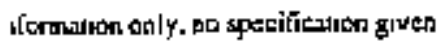




\section{CONSOLIDATION}

; dF sotLs

ASTM D 2435-90

\section{Raytheon Services Nevada MATERIALS TESTING LABORATORY NEVADA TEST SITE}

\begin{tabular}{ll}
\hline \hline Project: & 10C CRATEE, LAND \\
Requestor: & A. ZIEGENBEIN \\
Location: & AREA 10 \\
Tested by: & D. ANDEASON
\end{tabular}

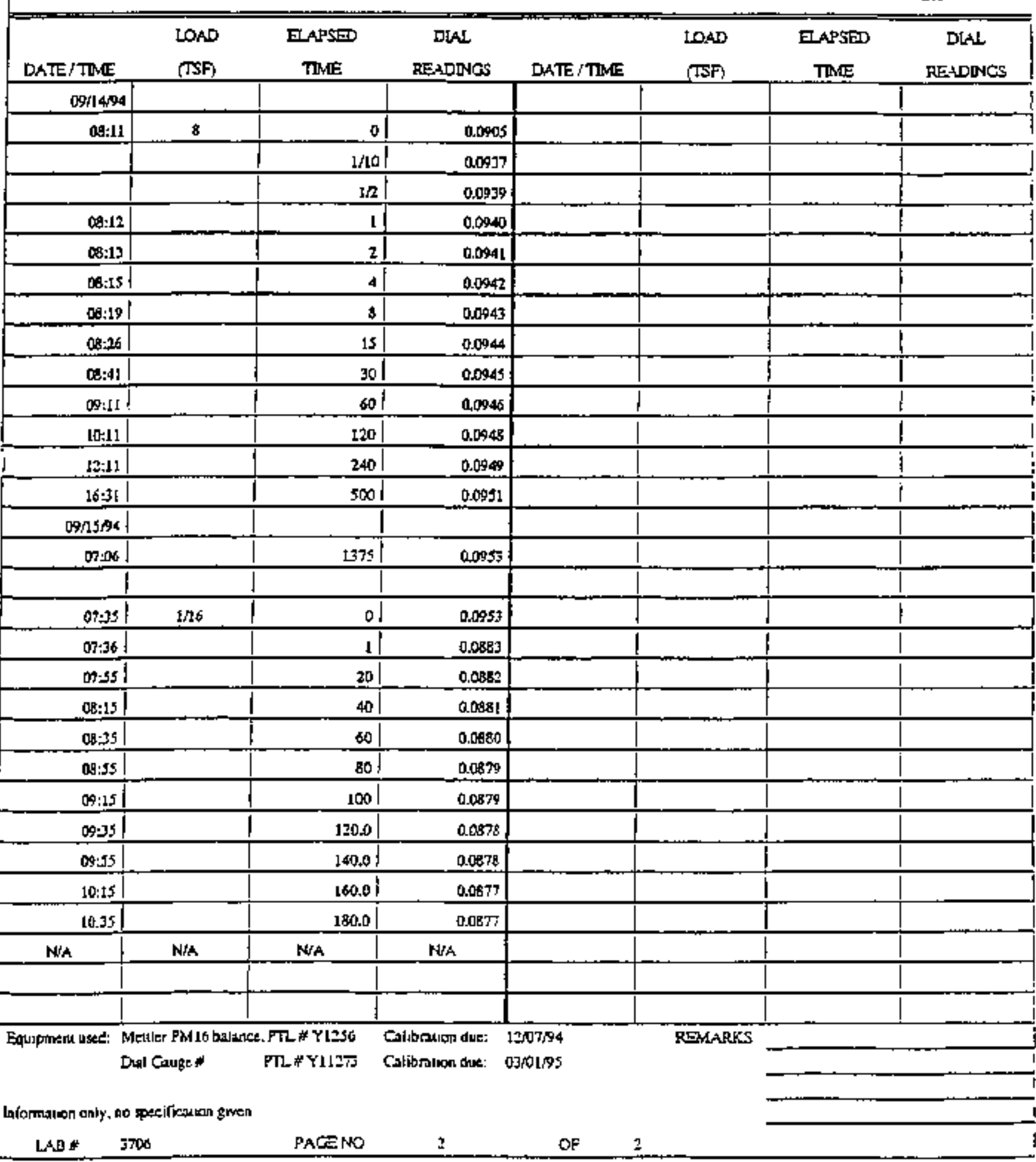

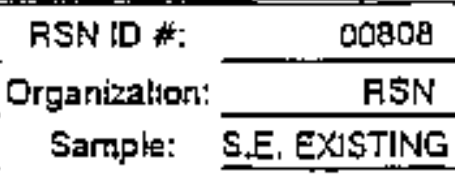




\begin{tabular}{|c|c|c|c|c|c|c|c|}
\hline \multicolumn{2}{|c|}{$\begin{array}{l}\text { CONSOLDATION } \\
\text { I OF SOILS } \\
\text { ASTM D2435-90 }\end{array}$} & \multicolumn{6}{|c|}{$\begin{array}{c}\text { Raytheon Services Nevada } \\
\text { MATERIALS TESTING LABOAATORY } \\
\text { NEVADA TEST SITE }\end{array}$} \\
\hline Projecti & \multicolumn{3}{|c|}{ 10C CRATEA, LANDFIப CLDSURE } & RSN ID \#: & \multicolumn{2}{|l|}{00808} & \\
\hline Requestor: & \multicolumn{3}{|c|}{ R. 그EGSNGEIN } & Organization; & \multicolumn{2}{|l|}{ RSN } & \\
\hline Location: & \multicolumn{3}{|l|}{ AREA 10 } & Sample: & \multicolumn{2}{|c|}{ N.E. EXISTING } & \\
\hline Tesied by: & \multicolumn{3}{|l|}{ D. ANDERSON } & Checked by: & \multicolumn{2}{|c|}{ D. HERAINGTON } & 24 \\
\hline & \multicolumn{3}{|c|}{ HOISTURE CONTENT } & \multicolumn{3}{|c|}{ (EEFORE) } & \\
\hline LAB * & TARE $*$ & werwT. & DRYWT & WATER & TARE WT: & DRY SOIL & MOSSTURE :F \\
\hline \multirow[t]{2}{*}{3767} & 4 & . 416.00 & 386.00 & 30.00 & 156.60 & $\ldots$...……… & {$[3.1$} \\
\hline & \multicolumn{3}{|c|}{ MOISTURE CONTENT } & \multicolumn{3}{|c|}{ (AFTER) } & \\
\hline LNE & TARE \# & WET WT & DRYWT. & WATER & TARE WT. & DRY SOLL & MOISTURE\% \\
\hline 3707 & 21 & 300.20 & $2+200$ & 77.00 & Dב3 & 133,90 & 17.2 \\
\hline \multicolumn{2}{|c|}{ RDE \& SAAPLEWT:(gni) } & 670,60 & PING WT(grol) & 520.10 & \multicolumn{2}{|c|}{ WEGTT OF SOIL. IN RNG (grm) } & $\$ 5330$ \\
\hline & DLAMETER & 25. & APEA (112) & 0.034088462 & \multicolumn{2}{|c|}{ VOUUME(t) $\left(H T=1,0^{\circ}\right)$} & 0.0028407052 \\
\hline \multicolumn{2}{|c|}{ SAMPLE WET UMIT WETCTI: } & 119.4 & $\cdot$ & & \multicolumn{2}{|c|}{ SAMPLEDRY UNIT WEGGT: } & 105.6 \\
\hline DATE TTME & $\begin{array}{l}\text { IOAD } \\
\text { (TSA) } \\
\end{array}$ & $\begin{array}{l}\text { EIAPSED } \\
\text { TDME }\end{array}$ & $\begin{array}{c}\text { DLAL } \\
\text { READINGS } \\
\end{array}$ & DATE / TTME & $\begin{array}{l}\text { IDAD } \\
\text { TSF } \\
\end{array}$ & $\begin{array}{l}\text { EAPSED } \\
\text { TWME }\end{array}$ & $\begin{array}{c}\text { DIAI } \\
\text { RESDINGS }\end{array}$ \\
\hline $0905 / 94$ & & & & 10.93 ] & $I / 2$ & 1 & 0.0635 \\
\hline \multirow[t]{2}{*}{$10: 27$} & $2 / 16$ & of & 0.0600 & 10,34 & & 2 & 0.0635 \\
\hline & & 1,10 & 0.0611 & & & & \\
\hline $10 \leq-18$ & & 1 & 0.0611 & $10: 34$ & 1 & ol & 0.0635 \\
\hline \multirow[t]{2}{*}{$10: 29$} & & 21 & 0.0510 & & & t/10 & 0.0651 \\
\hline & & & & & & $\mathbf{1 2}$ & 0.0652 \\
\hline \multirow[t]{3}{*}{$10=29$} & $1 / 8$ & 0 & 0.0610 & 10.35 & & 1 & 0.0653 \\
\hline & & L10 & $0.0 \times 12$ & $10: 36$ & & 2 & 0,0653 \\
\hline & & $1 / 2$ & 0.0612 & 10,98 & & 4 & 0.0653 \\
\hline \multirow[t]{2}{*}{$10: 30$} & & 1 & 0.0612 & & & & \\
\hline & & & & $10 \div 38$ & 2 & 0 & 0.0653 \\
\hline \multirow[t]{3}{*}{$20: 301$} & $1 / 4$ & 0 & 0.0612 & & & 1nol & 0.0676 \\
\hline & & trto & 0.0619 & & & $1 \Omega \mid$ & 00677 \\
\hline & & 12 & 0,0620 & $10: 39$ & & 1. & 0.0678 \\
\hline 10.31 & & 1 & 0.0620 & $10: 40$ & & 2 & 0.0678 \\
\hline 10:37! & & 2 & 0.0620 & 10:42 & & 4 & 0.0580 \\
\hline & & & & $10: 46$ & & B & $0.06 \mathrm{BO}$ \\
\hline 10:5? & $1 / 2$ & $\stackrel{0}{0}$ & 0.0620 & & & & \\
\hline & & $1 / 10$ & 0.0534 & & & & \\
\hline & & 12 & 0.0635 & & & & \\
\hline Equipment used: & Mettler PMI 6 bathice & $P I L \#$ Y 1256 & Colibogalkon due: & 120704 & REMARKS. & WATER ADDED D & RNEG 1116 TSF \\
\hline & Dat Curge H & $P R=$ Y112TS & Clibratron due- & 03,01,9s & & DAD EGTORE IM & IN PE \\
\hline id radurgs = $=00$ & & & & & & & \\
\hline man & se specificulong gim & & & & & & \\
\hline
\end{tabular}




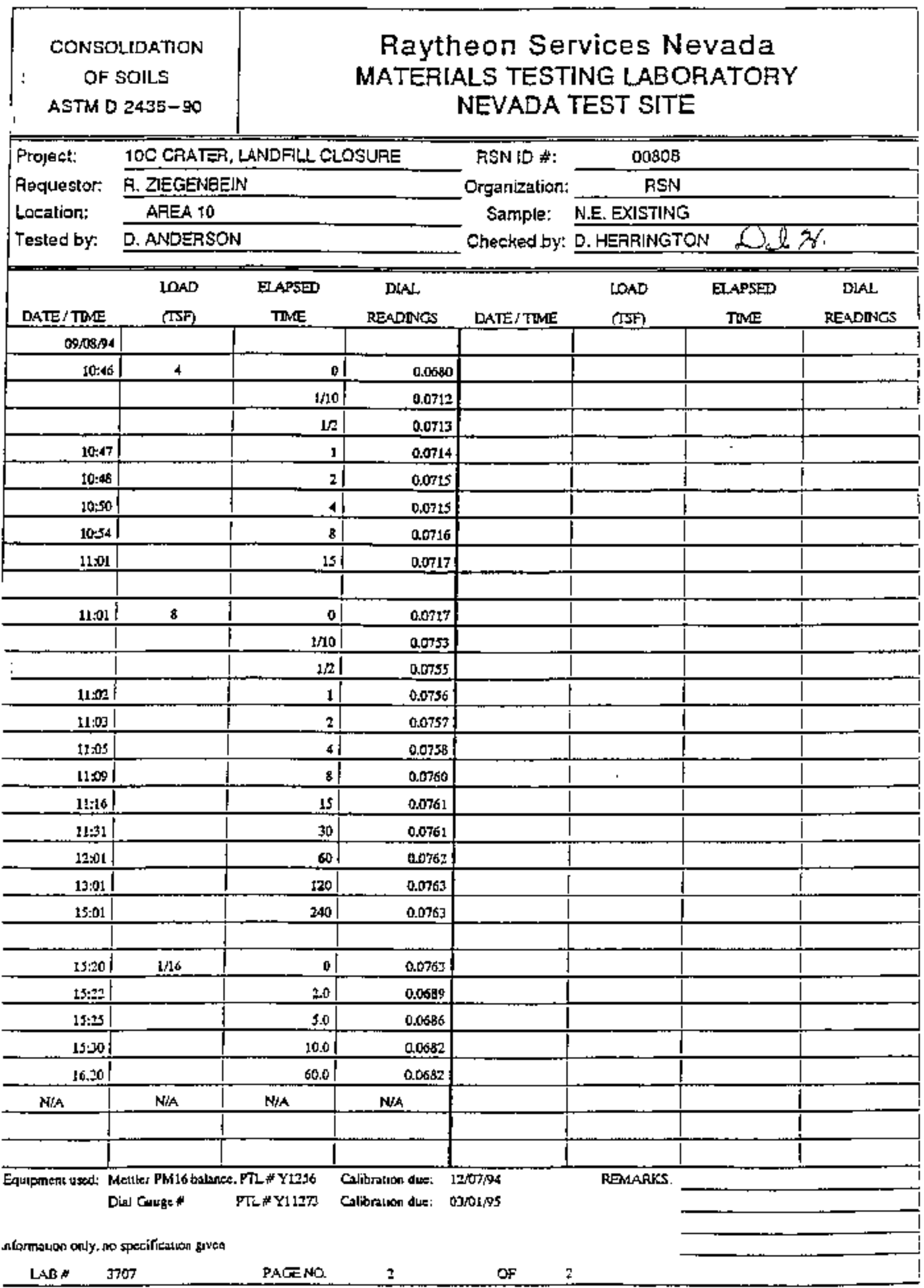


CONSOUDATION

OF SOILS

ASTM 02435-90

\section{Raytheon Services Nevada}

MATERIALS TESTING LABORATORY

NEVADA TEST SITE

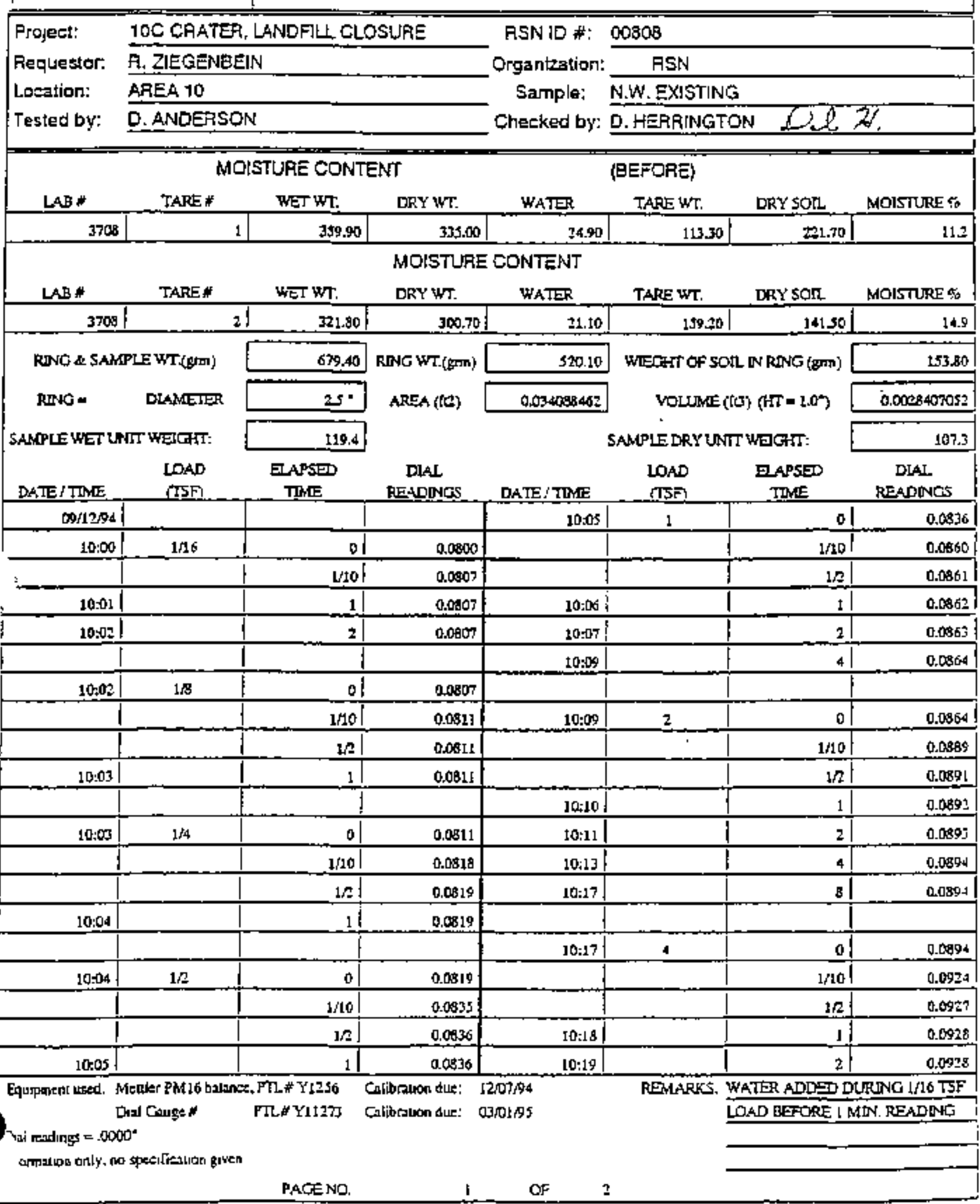


CONSOLIDATION

OF SOLLS

ASTM 0 2435-90
Raytheon Services Nevada MATERIALS TESTING LABORATORY NEVADA TEST SITE

\begin{tabular}{|c|c|c|c|c|c|c|c|}
\hline Project: & \multicolumn{3}{|c|}{106 CFATF, LANDFILL CLOSURE } & RSN ID \#: & 00808 & & \\
\hline Requestor: & \multicolumn{3}{|c|}{ R. ZIㅡGㅡNNBE!N } & Organization: & RSN & & \\
\hline Location: & \multicolumn{3}{|c|}{ AREA TO } & Sampla: & \multicolumn{3}{|l|}{ N.W. EXISTING } \\
\hline \multirow{2}{*}{ Tested by: } & \multicolumn{3}{|c|}{ D. ANDERSON } & \multicolumn{4}{|c|}{ Checked by: D. HERFINGTON } \\
\hline & DAمL & ELAPSED & $D L A \perp$ & & LOAD & DـAPSD & DLAL \\
\hline DATE /TOME & $(T S P)$ & TME & READNCS & DATE/TIME & (TSF) & TMME & PEAINNGS \\
\hline \multicolumn{8}{|l|}{$0 \$ 11294$} \\
\hline \multirow[t]{2}{*}{$10: 21$} & 4 & 4 & 0.0929 & & & & \\
\hline & & & & & & & \\
\hline \multirow[t]{3}{*}{$10: 21$} & 8 & 20 & 0.0929 & & & & \\
\hline & & 110 & 0.0973 & & & & \\
\hline & & $1 / 2$ & 0.0976 & & & & \\
\hline$\frac{10: 22}{10:-1}$ & & 1 & 0.0978 & & & & \\
\hline j0:-21 & & 2 & 2,0979 & & & & \\
\hline to:a & & 4 & 0.0980 & & & & \\
\hline \multirow{2}{*}{$\frac{10.29 !}{10: 36\}}$} & & 8 & $0.098 t$ & & & & \\
\hline & & 15 & 0.0982 & & 1 & & \\
\hline 10.51 & & 30 & 0.0985 & & & & \\
\hline 1121 & & 60 & 0.0986 & & 1 & & \\
\hline \multirow{2}{*}{$\frac{12 \geq 1}{1421}$} & & 120 & 0.0988 & & & & \\
\hline & & 240 & 0.0989 & & & & \\
\hline 27:01 & & 400 & $0 . \cos \theta$ & & & & \\
\hline \multicolumn{8}{|l|}{$09 / 13 / 94$} \\
\hline \multirow{2}{*}{$\overline{07: 01}$} & & 1240 & 0.0993 & & & & \\
\hline & & & & & & & \\
\hline 0701 & $1 / 16$ & a & 0.0993 & & & & \\
\hline $07.03 !$ & & 2 & 0,0918 & & & & \\
\hline 07:16 & & 15 & 0.0918 & & & & \\
\hline \multirow[t]{2}{*}{ N/A } & N/A & N/A & N/A & & & & \\
\hline & & & & & & & \\
\hline \multirow{3}{*}{$-\cdots$} & & & & & & & \\
\hline & & & & & & & \\
\hline & & & & & & & \\
\hline \multirow{2}{*}{-1} & & & & & & & \\
\hline & & & & & & & \\
\hline & & & & & & & \\
\hline & & & & & 1 & & \\
\hline Equpment used. & Metuler PM16 bs & $=$ PTL Y Y1.36 & Colibtalasan due & $1207 / 44$ & REMARXS. & & \\
\hline & Dal Couge " & FI*Y1112J & Caliordion due. & DJTIRS & &. & \\
\hline nfomsuluon ody, no & 0 spectikatuo s & & & & & & \\
\hline LAD\#" 3 & 3700 & PACEF NO & 2 & of & & & \\
\hline
\end{tabular}


CONSOLIDATION

OF SOILS

ASTM D 2435-90
Raytheon Services Nevada MATERIALS TESTING LABORATORY NEVADA TEST SITE

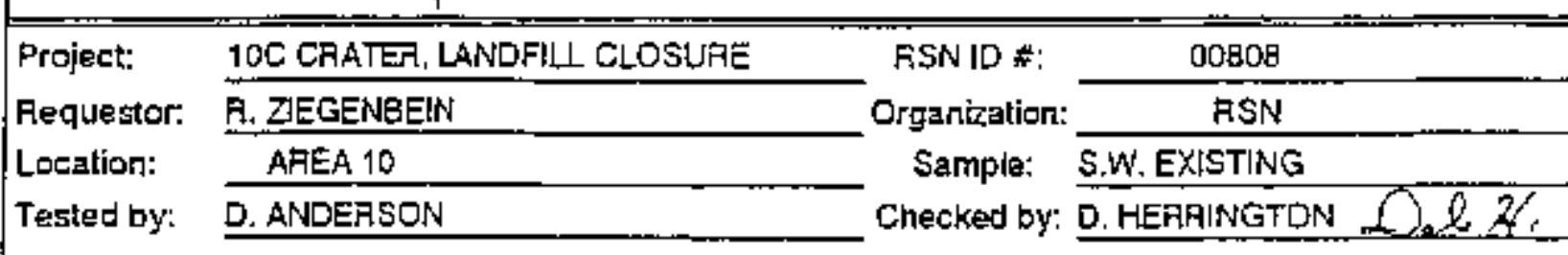

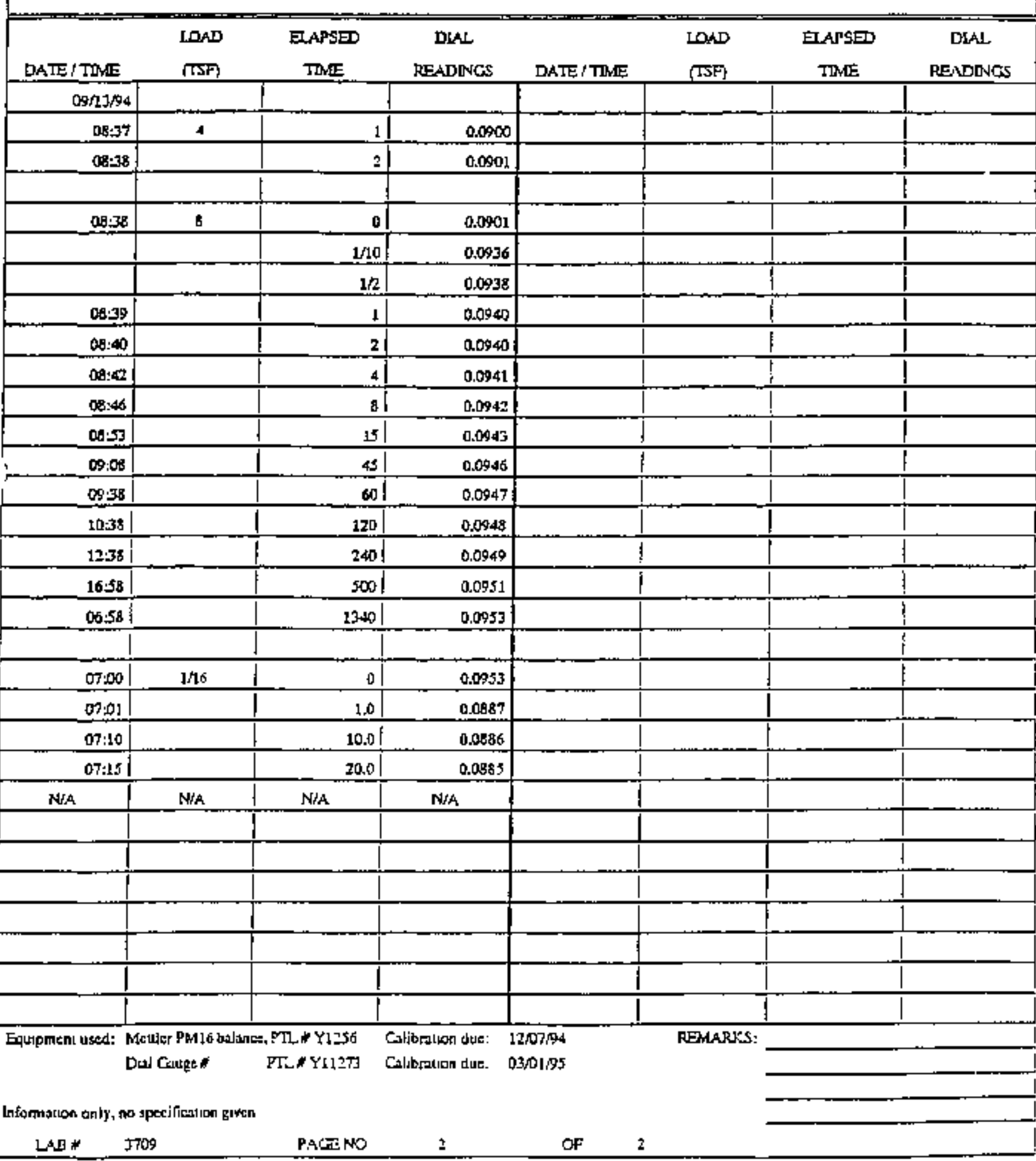




\section{CONSOLIDATION (ASTM D2435-90)}

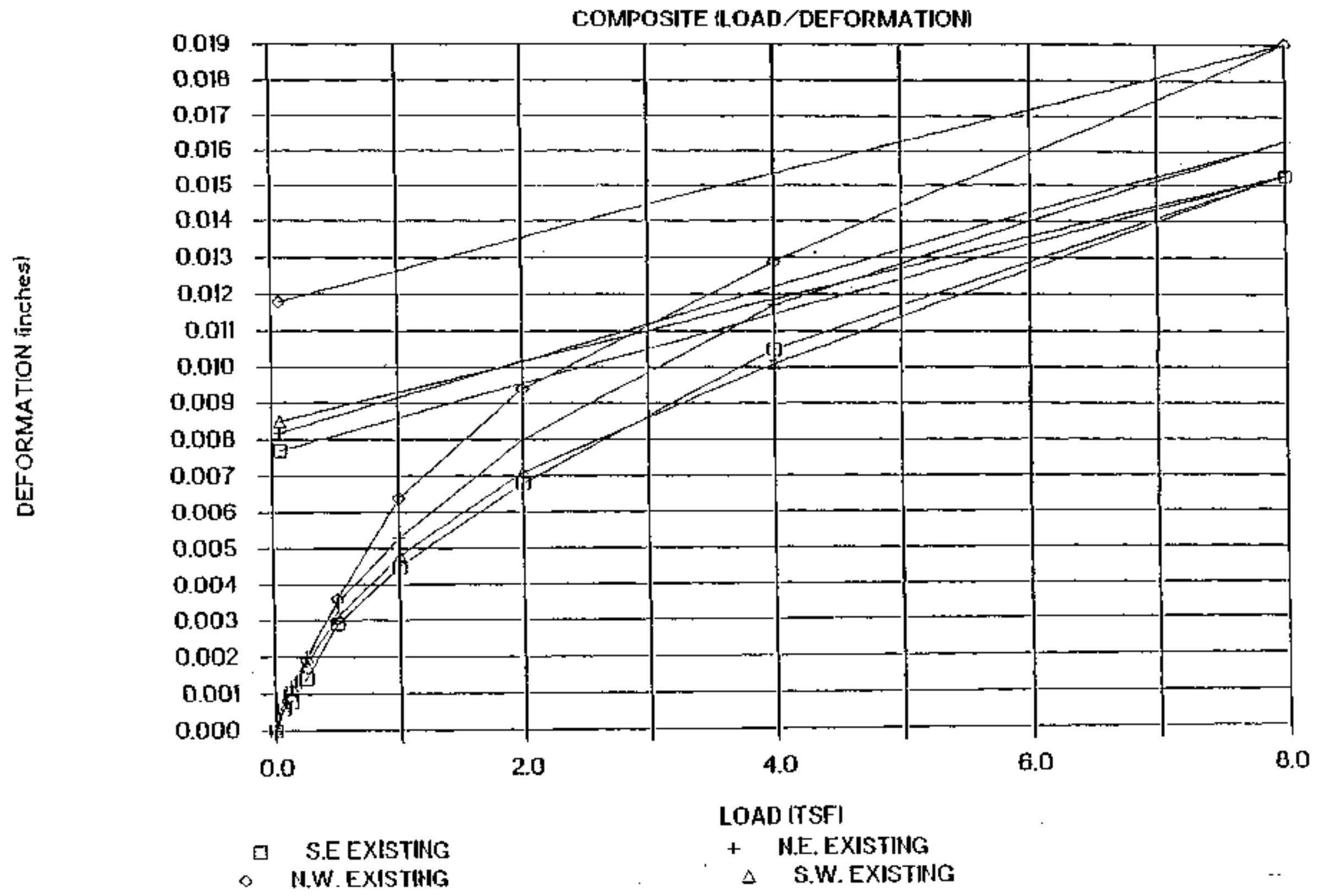


CONSOLIDATION (ASTM D2435-90)

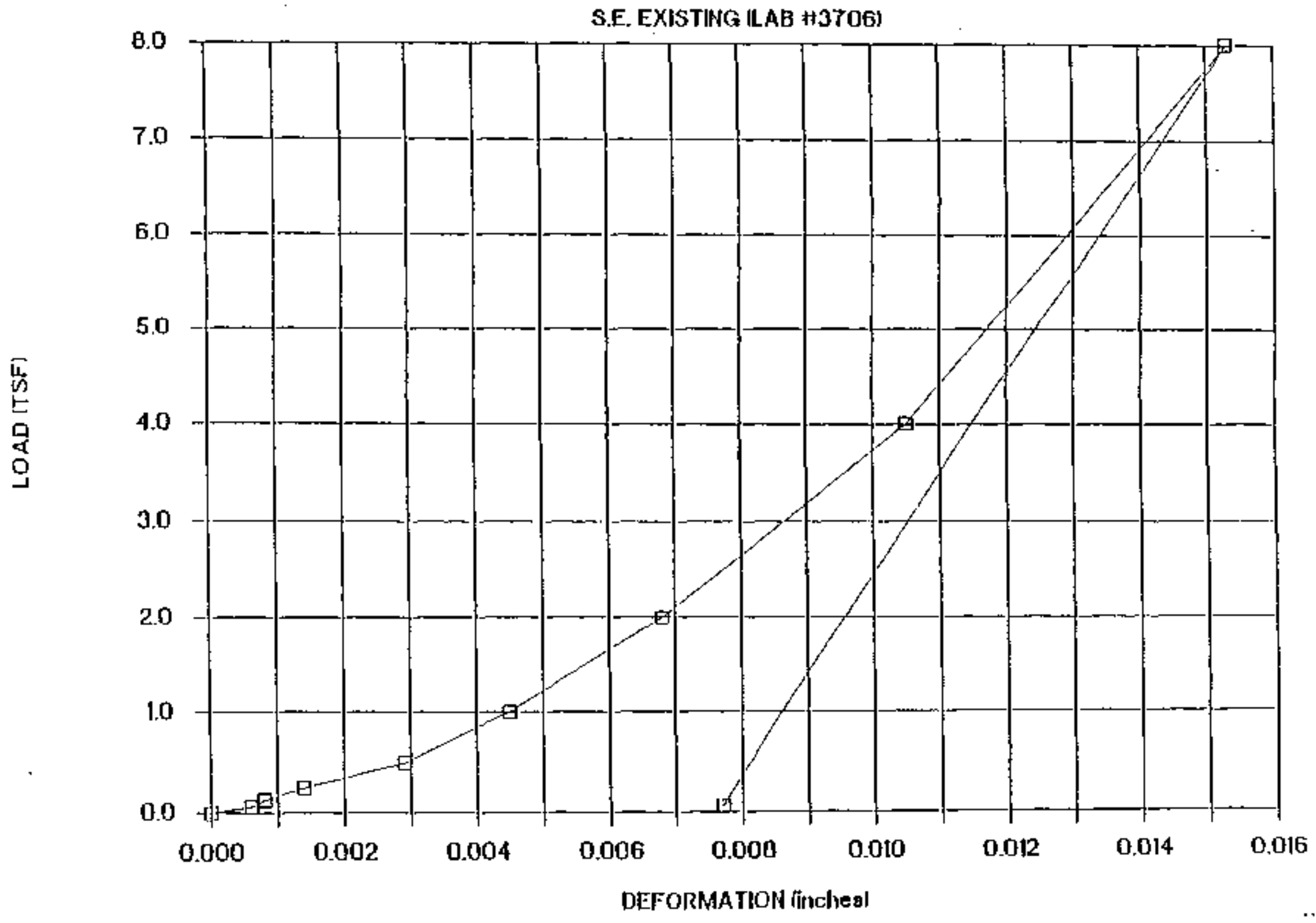




\section{CONSOLIDATION (ASTM D2435-90)}

N.E. EXISTING (L.AB \#3707)

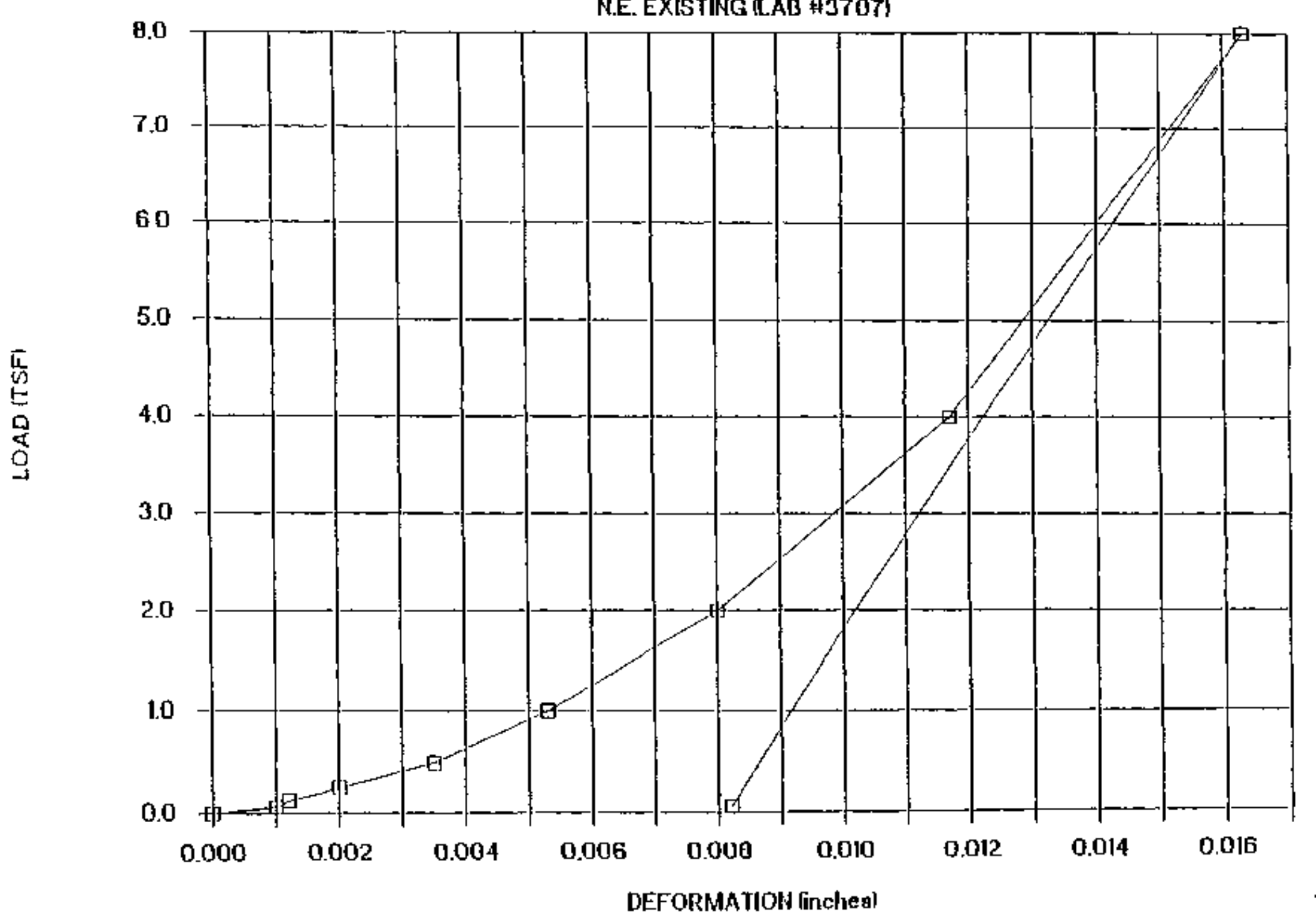


CONSOLIDATION (ASTM D2435-90)

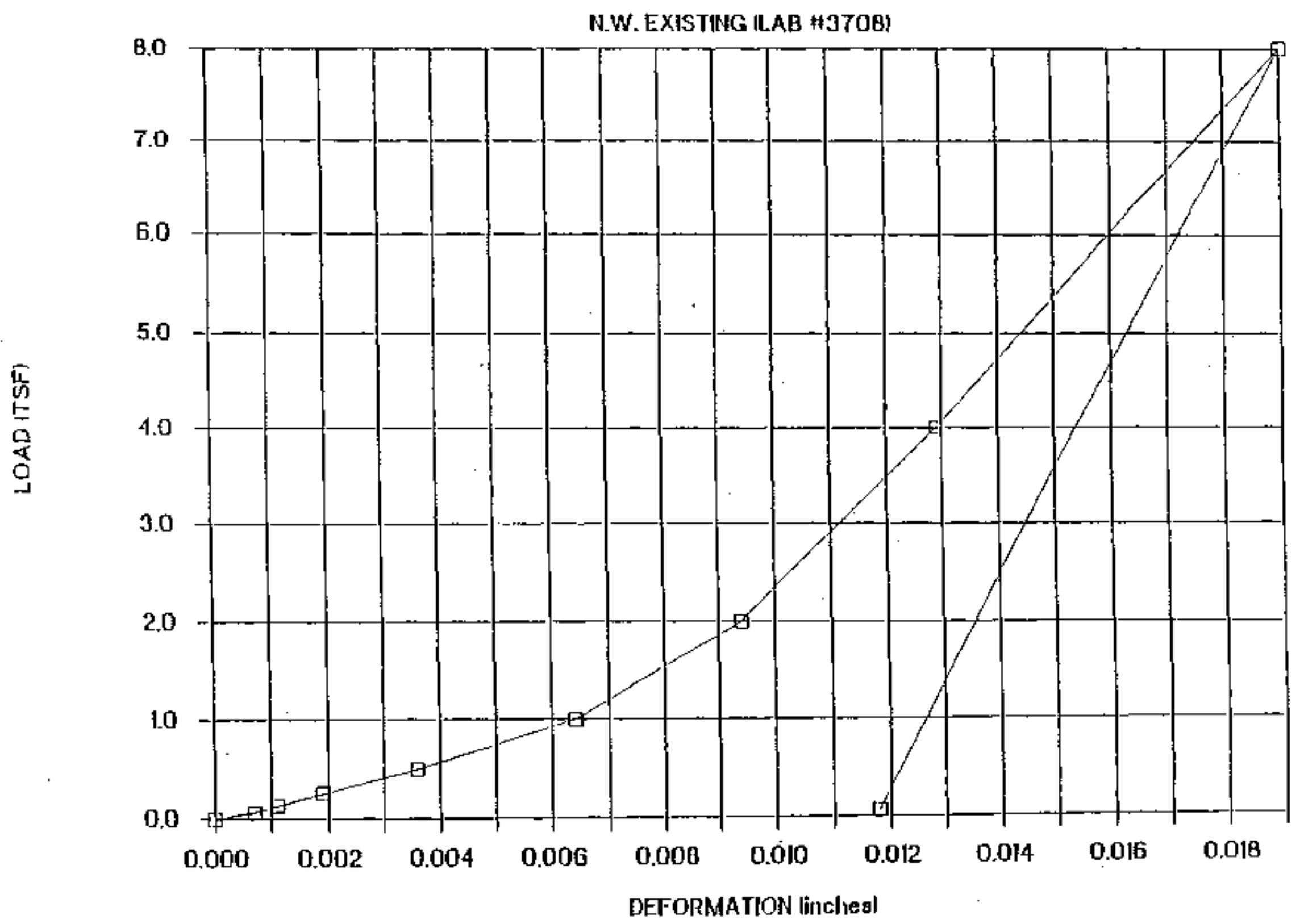


CONSOLIDATION (ASTM D2435-90)

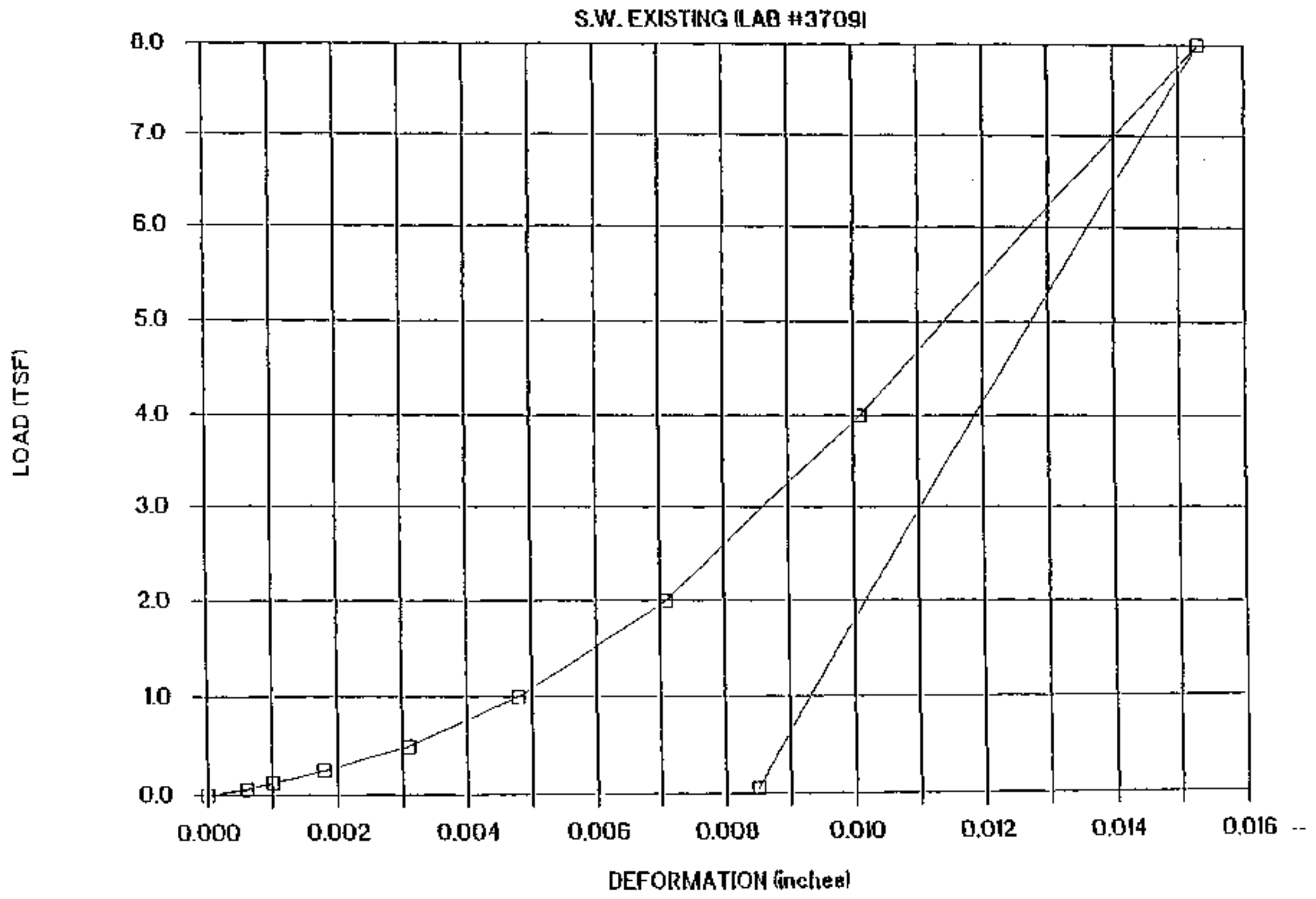


DIRECT SHEAR

OF SOILS

AstM D 3080-90

\section{Raytheon Services Nevada MATERIALS TESTING LABORATORY; NEVADA TEST SITE}

\begin{tabular}{lc}
\hline \hline Project: & 10C CRATER, LANDFIL CLOSURE \\
\cline { 2 - 2 } Requestor: & R. ZEGGENEENN \\
Organizatıon: & RSN \\
Sample Zone: & S.E. EXISTNG \\
Unit Wieght: & $119.4 \quad$ PCF \\
\hline
\end{tabular}

Tested by:

Tost dale:

RSN ID \#:

Checked by:

Check date:
D. ANDERSON

$08 / 31 / 94$

0080日

D. HERAINGTON SLl. 2 .

9-20-9y

\begin{tabular}{|c|c|c|c|c|c|c|c|}
\hline \multirow[b]{2}{*}{ LABA } & \multicolumn{3}{|c|}{ MOISTURE CONTENT } & \multicolumn{3}{|c|}{ (AFTEA) } & \multirow[b]{2}{*}{ MOISTURE To } \\
\hline & TAREI & WETWT. & DRYWT. & WATER & TARE WT. & DRY SOIL & \\
\hline 37005 & 21 & 278.6 & 260.4 & 1821 & \multicolumn{2}{|c|}{ 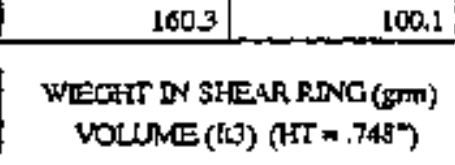 } & 28.2 \\
\hline \multirow{2}{*}{$\begin{array}{l}\text { NOFMAL = } \\
\text { RNG = }\end{array}$} & LOAD (gm) & 28345 & \multirow{2}{*}{$\begin{array}{l}\text { STRES (pto) } \\
\text { AREN (LC) }\end{array}$} & \multirow{2}{*}{\begin{tabular}{|r|}
1088.8 \\
0.014008 .164 \\
\end{tabular}} & \multirow{2}{*}{\multicolumn{2}{|c|}{ 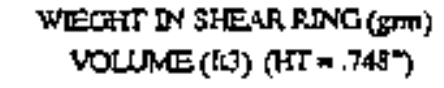 }} & i15.064130111 \\
\hline & & 25 & & & & & $0.0021>49369$ \\
\hline ELAPSED & SHEAR & SLEAR & NORMLAL & NOFMAL & PROVING & SHEAR & SHEAR \\
\hline $\begin{array}{l}\text { TDVE } \\
\text { (min) }\end{array}$ & $\begin{array}{c}\text { DLAL } \\
\text { (methes) }\end{array}$ & 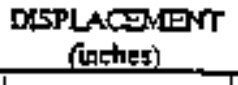 & 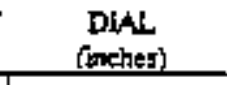 & $\begin{array}{c}\text { DISPLACGMNI } \\
\text { (waches) } \\
\end{array}$ & $\begin{array}{c}\text { RNC } \\
\text { (inchest:10000 }\end{array}$ & $\begin{array}{c}\text { FoRCE } \\
\text { flbsi } \\
\end{array}$ & $\begin{array}{c}\text { stRers } \\
\cos ()\end{array}$ \\
\hline $17: 37$ & & & 0,000 & 0.000 & & & \\
\hline 1 & & & 0,020 & 0.020 & & & \\
\hline$s$ & & & 0,021 & 0.021 & & & \\
\hline 101 & $0,000\}$ & 0.000 & 0.078 & 0.022 & 0.0 & & \\
\hline & Q0, 005 & 0.005 & 0.022 & 0.022 & 23.0 & 9.010 & $26+2$ \\
\hline & o.to & 0.010 & 0.073 & 0.0023 & 26.0 & 9.9 .48 & 291.8 \\
\hline & 0.015 & a.ts & Q.nt? & $0.0 \mathrm{~m}$ & 270 & 10,260 & 301.0 \\
\hline & 0,0201 & 0.020 & 0,003 & o.t. & 46.0 & $16.19 \mathrm{~B}$ & 475.2 \\
\hline & 0,000 & $0.00 \mathrm{~s}$ & $\underline{0.073}$ & 0.09 & 54.0 & 18.696 & 546.5 \\
\hline & 0,030 & 0.030 & 0,033 & 0.00 & 56.0 & 19.52 & 566.8 \\
\hline & 0,040 & 0.040 & 0.022 & $0.9 m$ & 36.0 & 19373 & 566.8 \\
\hline & 0.050 & 0.030 & 0.022 & $0,02 \geq 1$ & 56.01 & 19327 & 5668 \\
\hline & 0.055 & $0.0 \leq 5$ & 0.021 & 0.021 & 31.0 & 17.760 & $\sin 0$ \\
\hline 17.53 & 0050 & 0,060 & 0.021 & 0.021 & 45.0 & 15.885 & 166.0 \\
\hline & & & & & & & \\
\hline & & & & & & & \\
\hline & & & & & & & \\
\hline & & & & & & & \\
\hline & & & & & & & \\
\hline & & & & & & & \\
\hline & & & & & & & \\
\hline & & & & & & & \\
\hline & & & & i & & & \\
\hline & p & 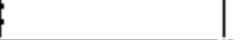 & & & & & \\
\hline Equiptosed used: in & Settler PMI6 bolinne & CE,PTL\# Y Y7S66 & Calbrautun due: & $1203 / 94$ & REMARSS. ! & WATER ADDEDB & ETMEEN IMEN \\
\hline & Dat Cauge \# & FTt 741 & Coliorian due: & $02 / 20 / 95$ & & $A N D 5 M I N$ REAL & ING \\
\hline & Dal Gauge " & FTL $* 5523$ & Calubration due: & $09 / 16 / 44$ & & SHEAR STH RTIT) & AFTER $10 \mathrm{MN}$ \\
\hline & Dul Gauge" & $P T L * 5864$ & Culteration dus: & $09 / 16 / 94$ & & CONSOLOATION & READING \\
\hline
\end{tabular}


DIRECT SHEAR

OF SOILS

ASTM D $9080-90$

\section{Raytheon Services Nevada MATERIALS TESTING LABORATORY NEVADA TEST SITE}

Project:
Requestor:
Organizatıon:
Sample Zone.
Unit Wraght:

Tested by:

Test date:

FSN ID \#:

Checked by:

Chack date:
D. ANDERSON

$08 / 31 / 94$

00808

D. HERRINGTON SOR

7.20.94

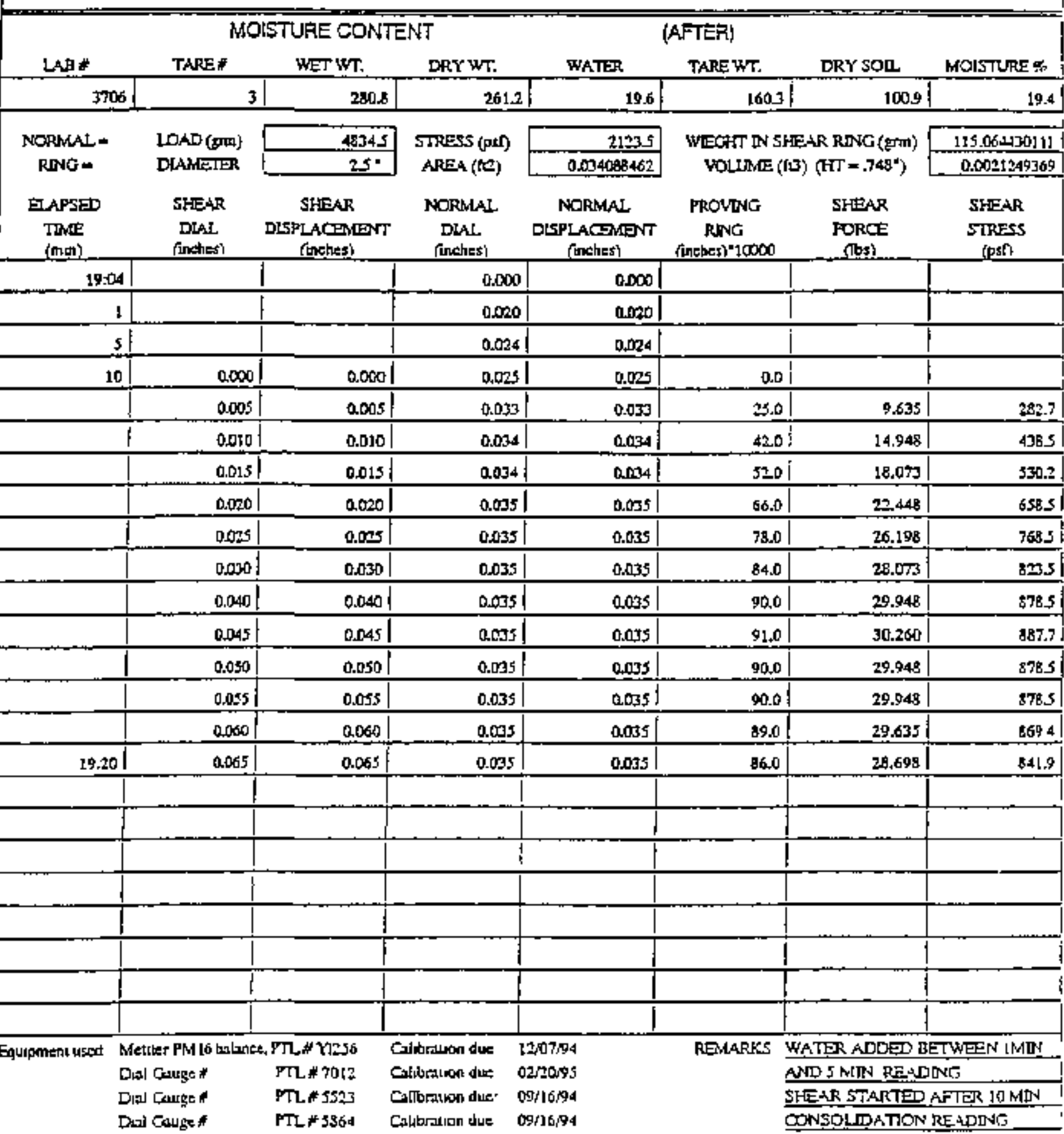


DIRECT SHEAR

OF SOILS

ASTM D 3080 90

\section{Raytheon Services Nevada MATERIALS TESTING LABORATORY NEVADA TEST SITE}

\begin{tabular}{|c|c|}
\hline Propect: & 100 OFATER, LANOFIL CLOSURE \\
\hline Fequestor: & R. 기톤ㅋNBEIN \\
\hline Organization: & RSN \\
\hline Sample Zone: & S.E. EXISTING \\
\hline Unit Wieght: & 119.4 \\
\hline
\end{tabular}
MOISTURE CONTENT

\begin{tabular}{|c|c|}
\hline LAB H & TARE \\
\hline 3706 & \\
\hline NORMAL = & LOND (gनr) \\
\hline RNG $=$ & OLANEIER \\
\hline
\end{tabular}

EAPSED SHEAR

\begin{tabular}{|c|c|}
\hline WET WT. & DRYWT. \\
\hline 2785 & 257.0 \\
\hline 6030,5 & STRESS (pst) \\
\hline 2.54 & AREA (l) \\
\hline
\end{tabular}

Tested by:
Test date:
RSN ID \#: Checked by: Check date:

\begin{tabular}{c|}
\hline D.ANDERSON \\
\hline $09101 / 94$ \\
00808 \\
\hline 0. HEARINGTON SO 4 \\
\hline $7-20.94$ \\
\hline
\end{tabular}

[AFTEF]

WATER TAREWT. DRY SOLL MOISTURE G 158.4 21.88 .6

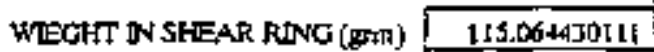
VOLIME, (fL3) $\left(\mathrm{HT}=.748^{*}\right) \quad 0.0021249369$

\begin{tabular}{|c|c|c|c|c|}
\hline $\begin{array}{c}\text { SHEAR } \\
\text { DSPLAC्टMERT }\end{array}$ & $\begin{array}{l}\text { NORMAL } \\
\text { DLAL }\end{array}$ & $\begin{array}{c}\text { MOFMAL } \\
\text { DSPLACDMENT }\end{array}$ & $\begin{array}{l}\text { PROVDNG } \\
\text { RING }\end{array}$ & $\begin{array}{l}\text { SHEAR } \\
\text { FORCE }\end{array}$ \\
\hline
\end{tabular}

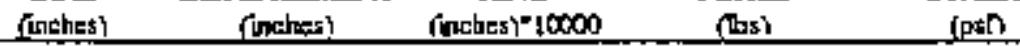

\begin{tabular}{|c|c|c|c|c|c|c|c|}
\hline$(\mathbf{m m})$ & (infiche) & [inchess) & (Lnchest & Sinchers? & (neches) 10000 & (thes) & $j \mathrm{pth}$ \\
\hline $08: 11$ & & & 0.000 & 0.000 & & & \\
\hline 11 & & & 0,0 & 0,024 & & & \\
\hline 5 & & & 0.027 & 0.027 & & & \\
\hline 101 & 0.0001 & 0.000 & 0.027 & 0.027 & 0.0 & & \\
\hline & 0.005 & $0, \infty \leq 1$ & 0,032 & $0.00 \%$ & 15.0 & 6510 & $\$ 91.0$ \\
\hline & 0.010 & 0.0101 & 0.053 & 0.033 & 1210 & 39.635 & 11627 \\
\hline & 0.0251 & 0.015 & ond ! & $0.03-4$ & 143.0 & $46510 !$ & I364.4 \\
\hline & 0.030 & 0.020 & 00035 & 0.053 & 175.0 & $\$ 6510$ & 1657.8 \\
\hline & 0.030 & 0.0301 & 0.036 & 0.036 & 269.0 & 67.135 & 1969.4 \\
\hline & 0.035 & 0.035 & 0.036 & 0.0066 & 221.01 & 70.885 & 2079.5 \\
\hline & 0.040 & $0,0,040$ & 0.036 & 0.036 & $=32.0$ & 74373 & $\$ 180.3$ \\
\hline & 0.0501 & 0.050 & 0.036 & 0.0361 & 247.0 & 79.010 & 7317,8 \\
\hline & 0.060 & 0.0501 & 0.036 & 0,036 & 261,0 & 83385 & 2446.1 \\
\hline & 0.080 & 0.080 & 0.097 & 0.037 & 269.01 & 85.885 & 2519.5 \\
\hline & 0.100 & 0.100 & 0.035 & 0.036 & 272.01 & 86.877 & 2547,0 \\
\hline & 0.125 & 0,175 & 0.055 & 0.035 & 270.01 & 86.073 & 2583.31 \\
\hline & 0.175 & 0.175 & 0.095 & 0.035 & 208.0 & 9․ㅛ를 & 2695.7 \\
\hline & 0.2001 & $0 \pm 01$ & 0,035 & 0.035 & 297.01 & 94.635 & 2776.2 \\
\hline & 0.25 & 0.5 & 0.035 & 0.035 & 300.01 & 95.57 & 2803.7 \\
\hline & 0.275 & 0.275 & 0.034 & 0.034 & 305.0 & 97.135 & 28495 \\
\hline & 0300 & 0.3001 & 0.033 & 0.0.0 & 510.0 & 96,698 & 28953 \\
\hline & 0.75 & 035 & 0.032 & 0.032 & 314.0 & 99,948 & 7932.0 \\
\hline & 0.350 & 0350 & a.dis & 0.0031 & 314.0 & 99.948 I & 2933.0 \\
\hline as-5a! & 0.3001 & 0,360 & 0.032 & 0.0321 & 311.0 & 99.010 & 2904.5 \\
\hline & 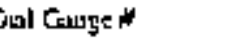 & FTL 7012 & Caliprition duc: & 022095 & & \multicolumn{2}{|c|}{ AND \$ MDN READONG } \\
\hline & 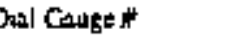 & PTL 1553 & Colibauan tux: & $09 / 6 / 94$ & & \multicolumn{2}{|c|}{ SFEAR STHWTED AFTIGR tO SIIN } \\
\hline & Dald Gent & PTL FBist & Clibruon due: & $0 \% 1694$ & & \multicolumn{2}{|c|}{ CONSOLIDATION READNG } \\
\hline
\end{tabular}




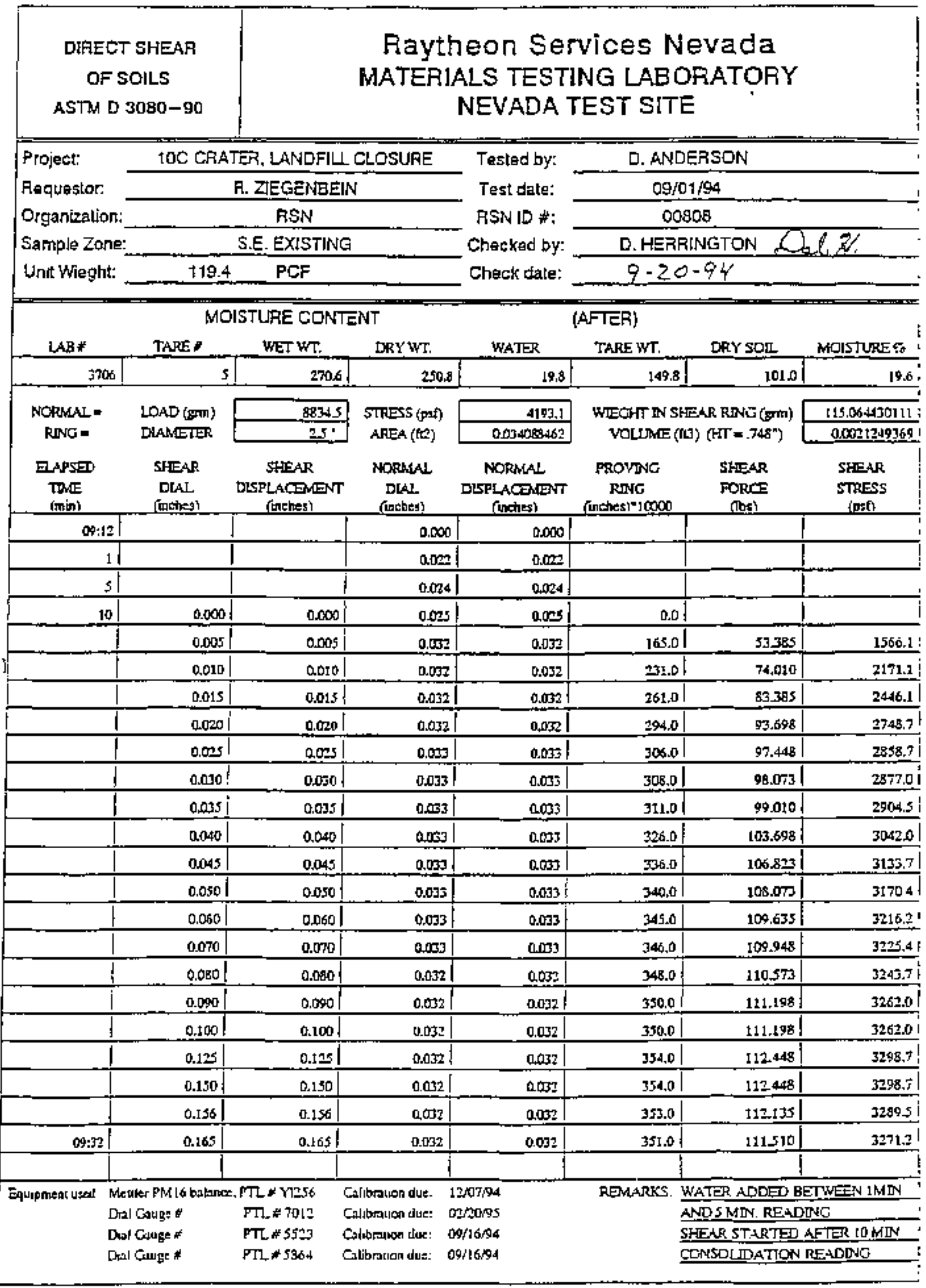




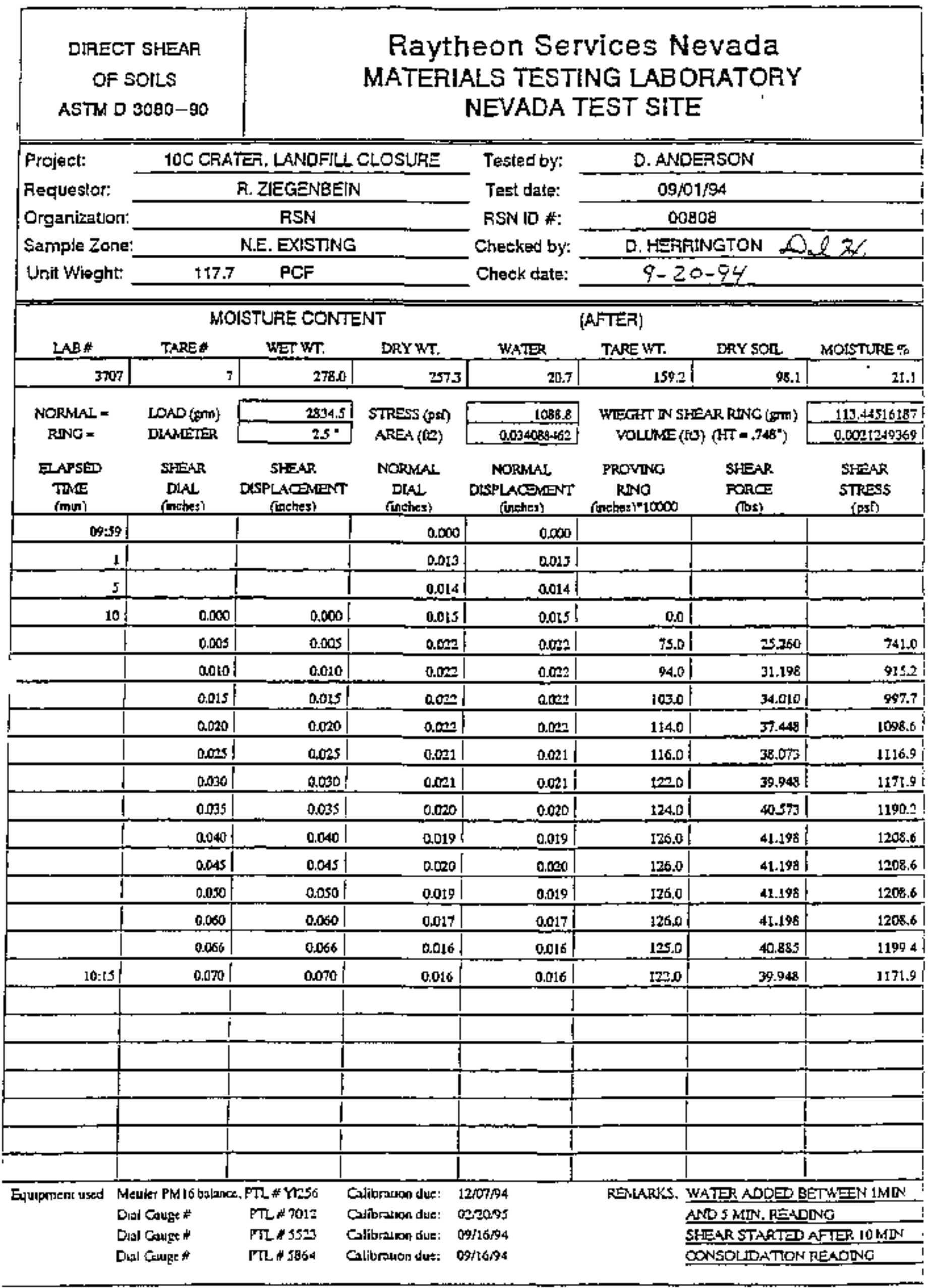




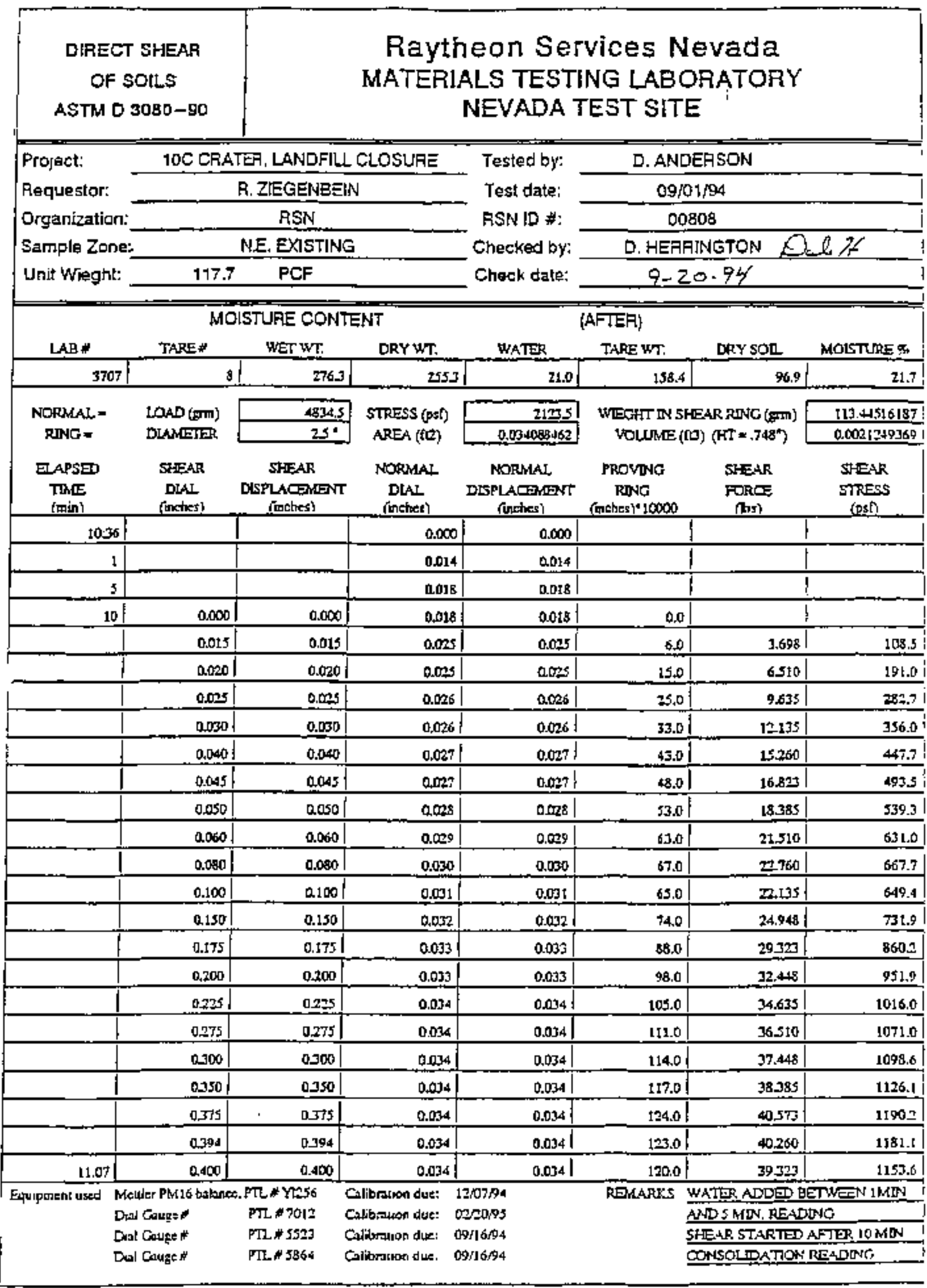




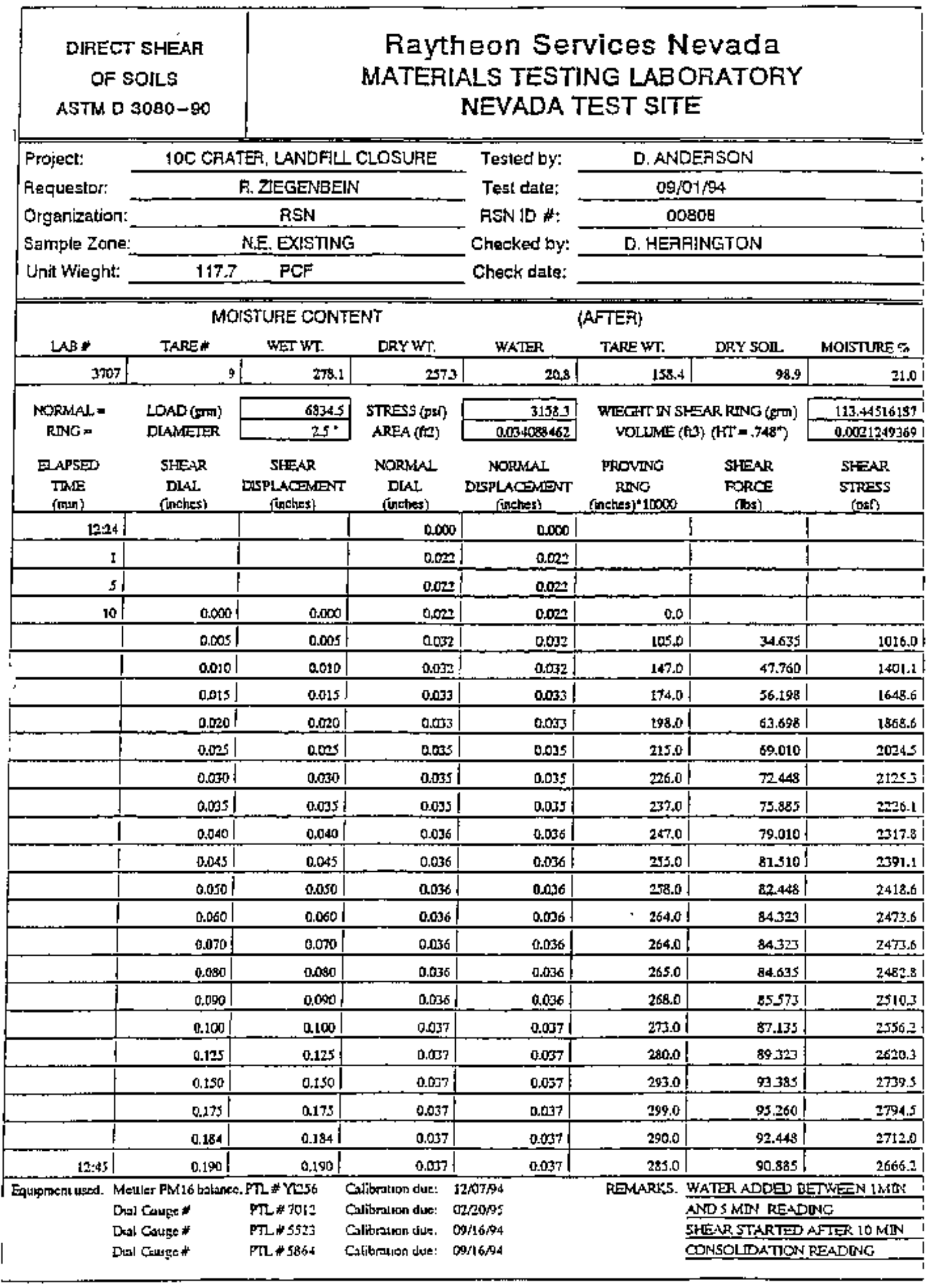




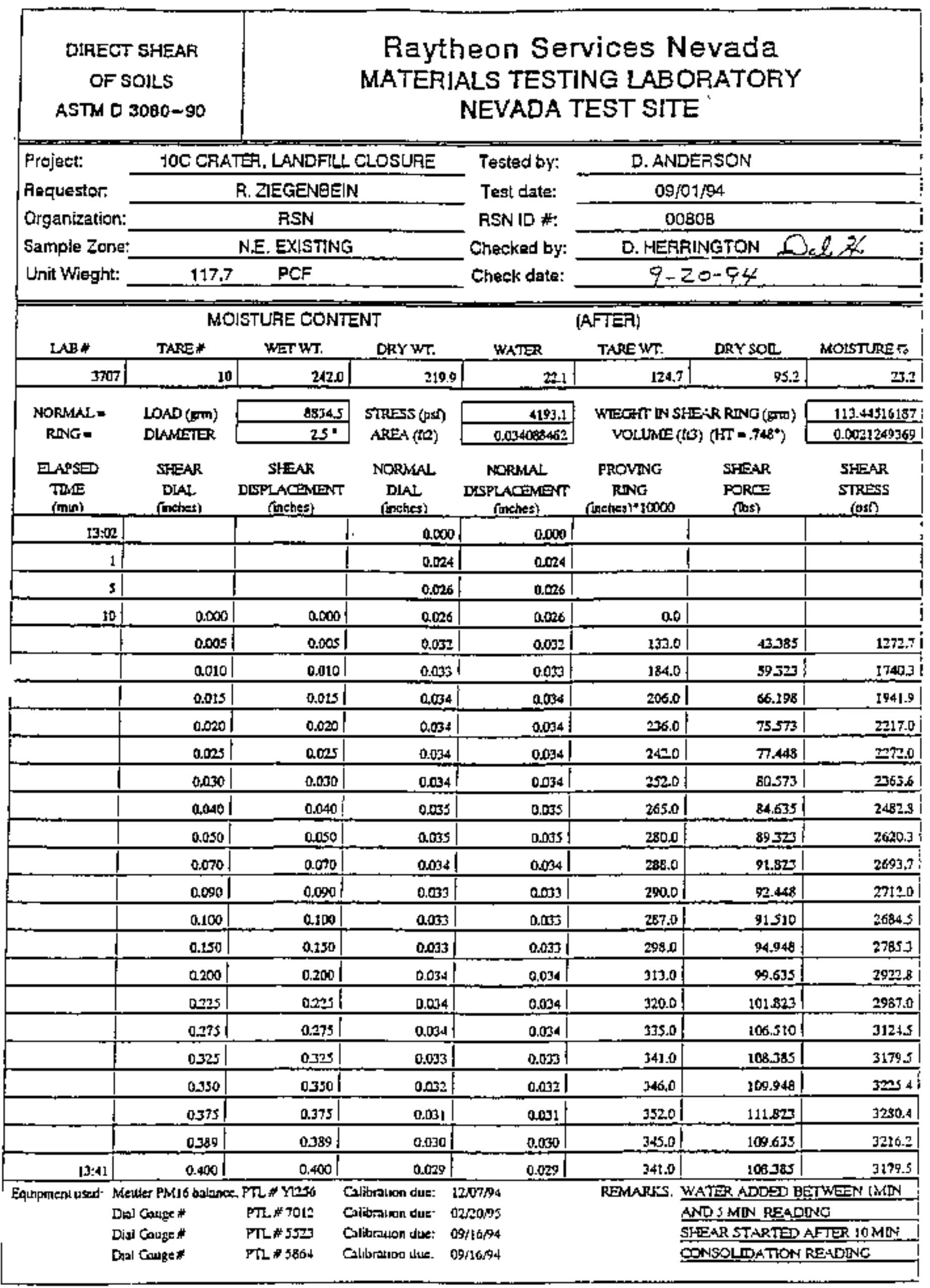




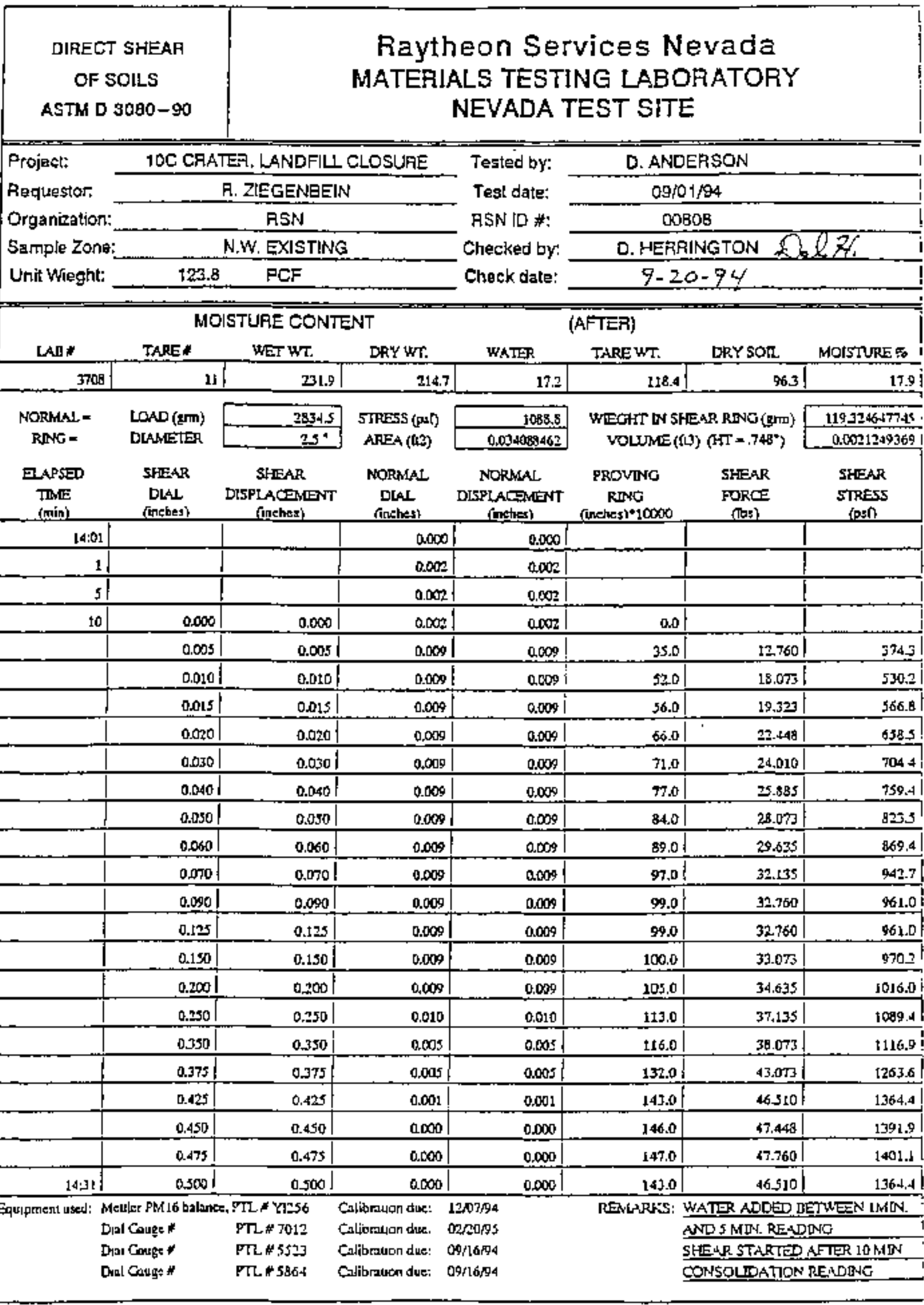




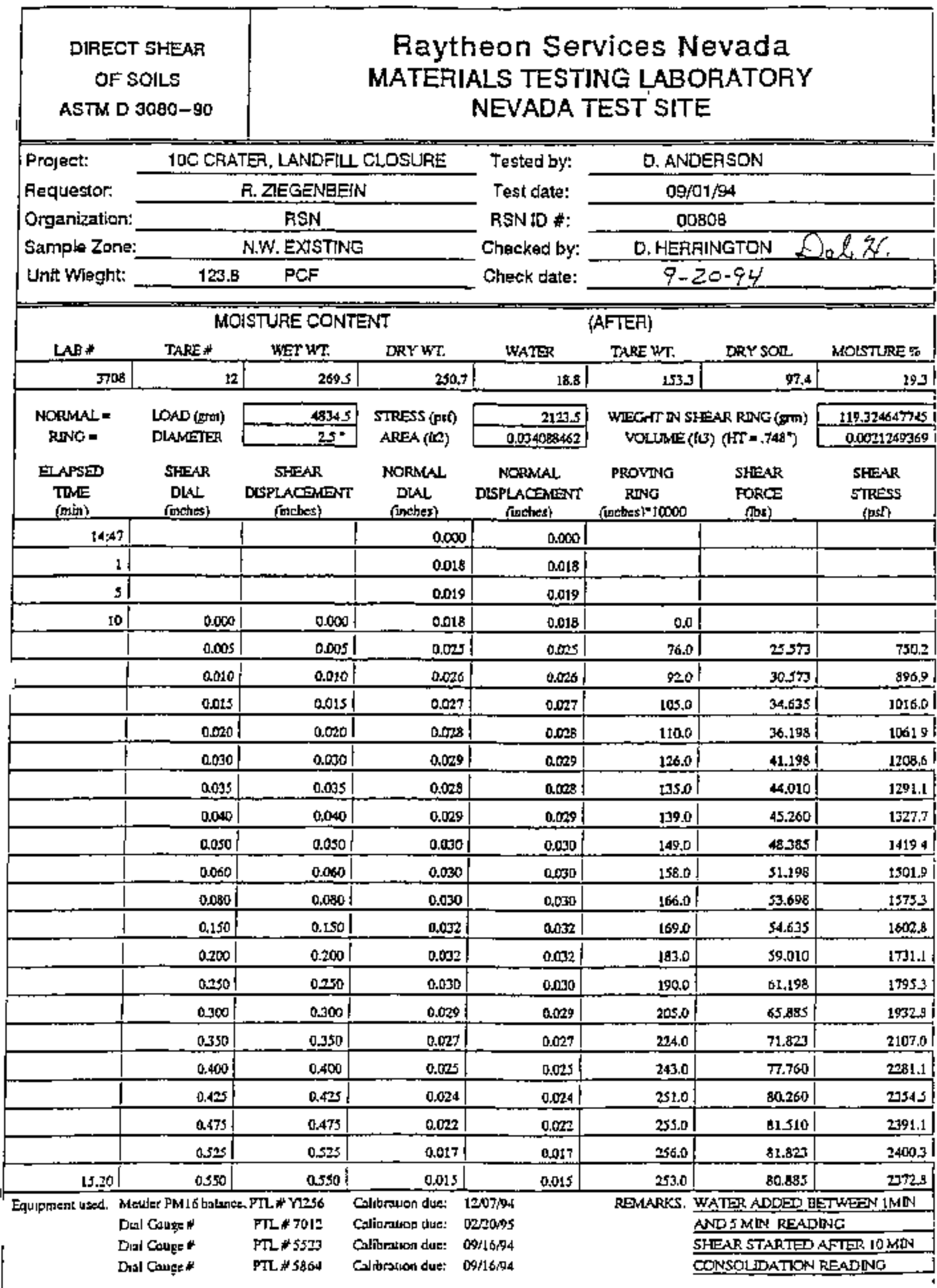




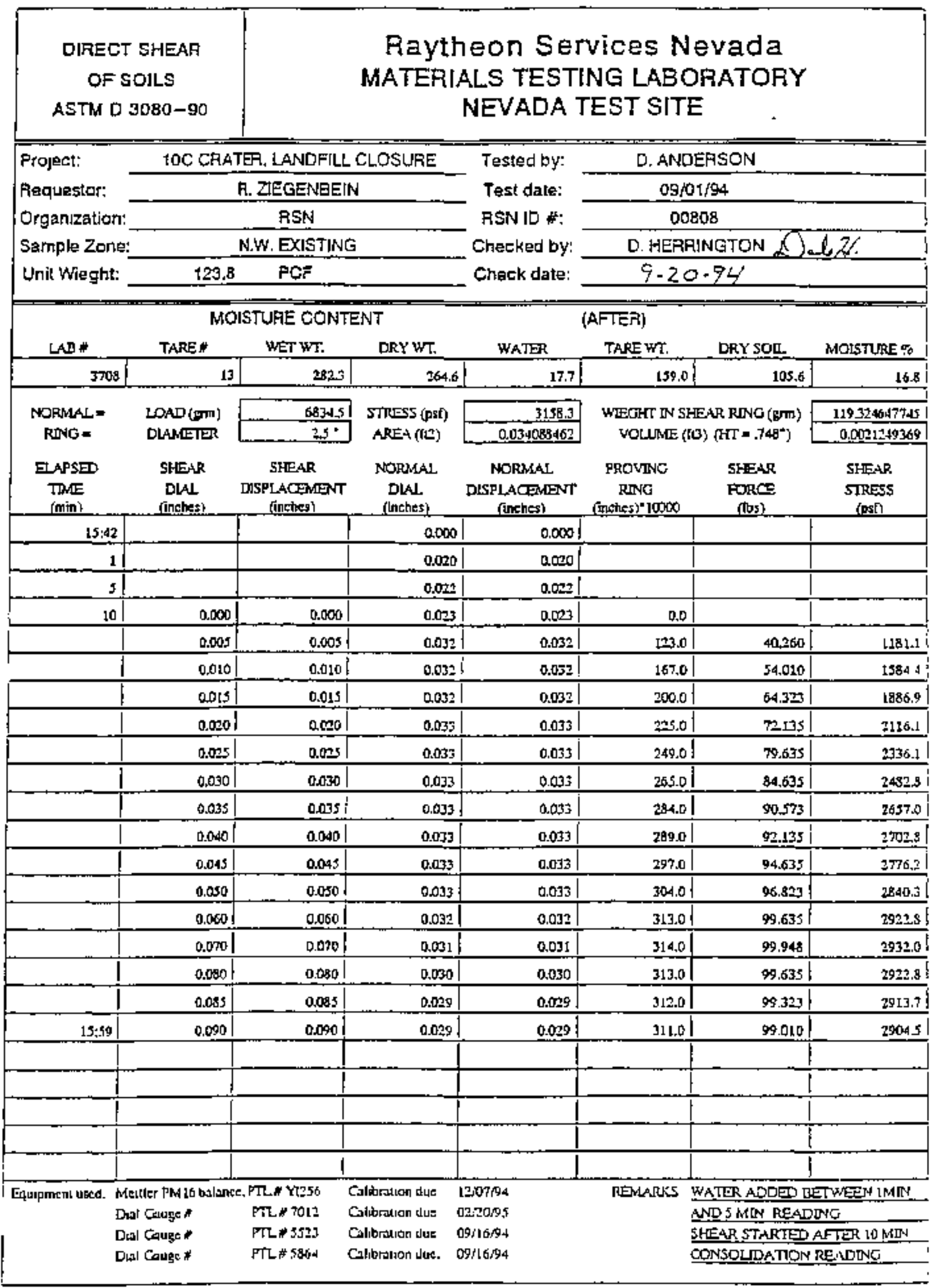




\begin{tabular}{|c|c|c|c|c|c|c|c|}
\hline \multicolumn{2}{|c|}{$\begin{array}{l}\text { DIRECT SHEAR } \\
\text { OF SOILS } \\
\text { ASTM D 3080-90 }\end{array}$} & \multicolumn{6}{|c|}{$\begin{array}{c}\text { Raytheon Services Nevada } \\
\text { MATERIALS TESTNGG LABORATOAY } \\
\text { NEVADA TEST SITE }\end{array}$} \\
\hline Project: & \multicolumn{3}{|c|}{ 10C CRATEA, LANDFU CLOSUAE } & \multirow{2}{*}{$\begin{array}{l}\text { Tested by: } \\
\text { Test date: }\end{array}$} & \multicolumn{2}{|c|}{ D. ANDEASON } & \\
\hline Requestor: & \multicolumn{3}{|c|}{ A. ZIEGENBEIN } & & \multicolumn{2}{|c|}{$09 / 01 / 94$} & \\
\hline Organization: & \multicolumn{3}{|c|}{ RSN } & RSN ID \#: & \multicolumn{2}{|c|}{0,0808} & \\
\hline Sample Zone: & \multicolumn{3}{|c|}{ N.W. EXISTING } & Checked by: & \multicolumn{2}{|c|}{ D. HERFINGTON } & 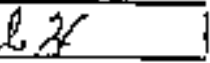 \\
\hline \multirow[t]{2}{*}{ Unit Wileght: } & 123.8 & \multicolumn{2}{|l|}{$\mathrm{PCF}$} & Check date: & \multicolumn{2}{|c|}{$9-20-94$} & \\
\hline & \multicolumn{3}{|c|}{ MOISTURE CONTENT } & \multicolumn{3}{|c|}{ (AFTER) } & \\
\hline LAB \# & TARE: & WET wT & DRY WT. & WATER & TARE WT: & DRY SOL & MOISTURE क \\
\hline 3708 & 14 & 275.5 & $2 \times 7.5$ & 130 & 152.5 & tos.0 & 17.1 \\
\hline $\begin{array}{l}\text { NORWAL = } \\
\text { RWNG= }\end{array}$ & $\begin{array}{l}\text { LOAD (gm) } \\
\text { DLAMBIER }\end{array}$ & $\frac{85345}{25}$ & $\begin{array}{l}\text { STRESS (post) } \\
\text { AREA (LC) }\end{array}$ & $\begin{array}{r}4193,1 \\
0.034008462 \\
\end{array}$ & \multicolumn{2}{|c|}{ 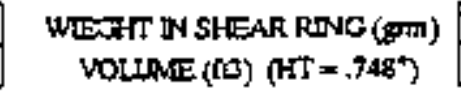 } & $\frac{1193246477+5}{0.0021249369}$ \\
\hline $\begin{array}{l}\text { ELAPSE } \\
\text { TDEE } \\
\text { (min) }\end{array}$ & $\begin{array}{c}\text { SLEAR } \\
\text { DLAL } \\
\text { finches\} } \\
\end{array}$ & $\begin{array}{l}\text { SHEAR } \\
\text { DSPLACEMENT } \\
\text { (inches) }\end{array}$ & $\begin{array}{l}\text { NORMAAL } \\
\text { DWN. } \\
\text { (babast) }\end{array}$ & $\begin{array}{l}\text { NOAMAL } \\
\text { DISPLACEMDENT } \\
\text { (nches) }\end{array}$ & $\begin{array}{c}\text { PROOVNG } \\
\text { RONG } \\
\text { (10ches) } 10000\end{array}$ & $\begin{array}{l}\text { SHEAR } \\
\text { FORCE } \\
\text { CPBS }\end{array}$ & $\begin{array}{c}\text { SFEAR } \\
\text { STRESS } \\
\text { (pEO }\end{array}$ \\
\hline $16: 24$ & & & 0.000 & $|0.000|$ & & & \\
\hline 1 & & & 0.027 & 0.027 & & & \\
\hline 5 & & & 0.029 & 0.029 & & & \\
\hline \multirow[t]{2}{*}{10} & 0.000 & 0,0001 & 0,000 & 0.030 & 0.0 & & \\
\hline & 0.005 & 0.005 & 0,050 & 0.039 & 135.01 & $\mathbf{4 4 . 0 1 0}$ & 1291.1 \\
\hline 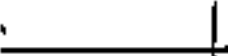 & a.010 & 0.010 & 0.040 & 0.040 & {$[45,0]$} & 47.135 & 1382.7 \\
\hline & 0.020 & 0.020 & 0.040 & 0.0401 & 160.0 & $51.82 \div$ & 1520.2 \\
\hline & 0.030 & b.togl & 0.040 & 0.040 & 185.0 & 59.675 & 17494 \\
\hline & 0.040 & 0,040 & [D(0)] & 0.041 & 213.0 & 68385! & 2000.1 \\
\hline & 0.050 & 0.050 & 0.041 & 0.041 & 200.0 & 73.6981 & 2162.0 \\
\hline & 0.0601 & 0.060 ! & 0.041 & 0.041 & 241.0 & $\pi .1 .151$ & 2261.8 \\
\hline & 0.075 & 0.075 & 0.041 & $0.04 i$ & 252.0 & 80,973 & 3063.6 \\
\hline & 0,100 & 0.100 & 0.040 & 0.040 & $2620^{\circ}$ & 83.698 & 24553 \\
\hline & 0.125 & 0.129 & 0.040 & $\underline{0.040}$ & 265.0 & 84.635 & 2481.5 \\
\hline & 0.150 & 0.590 & 0.009 & 0.039 & 264.0 & B43기 & 2473.6 \\
\hline & 0.175 & 0.175 & 0.038 & 0.038 & 263.0 & 84.010 & 2464.5 \\
\hline 14.45 & $0200 !$ & $0.2 \infty$ & 0.038 & 0.038 & 263.0 & 84.030 & $246-4.5$ \\
\hline & & & & & & & \\
\hline & & & & & & & \\
\hline & & & & & & & \\
\hline & & & & & & & \\
\hline & & & & & & & \\
\hline & & & & & & & \\
\hline Equnprtent used. & Meuder PMA16 balince. & $9 \pi$ A 1926 & Calbraulan dus: & 120nod & REALARKS. & ATRR ADOED BE & TWEN IMDN \\
\hline & Dav Gaume * & $\mathrm{PTR} * 7012$ & Catibraruon dos: & ozizass & & MD SMMN READ & \\
\hline & Oal Gamge ". & PIL $F S 25$ & 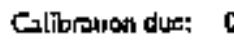 & 097654 & & HESRSTARTED & FIER $10 \mathrm{MN}$ \\
\hline & Den Couge " & PTL \# S864 & Calibration due & $9 / 16,94$ & & ONSOUIATDON & ENONG \\
\hline
\end{tabular}




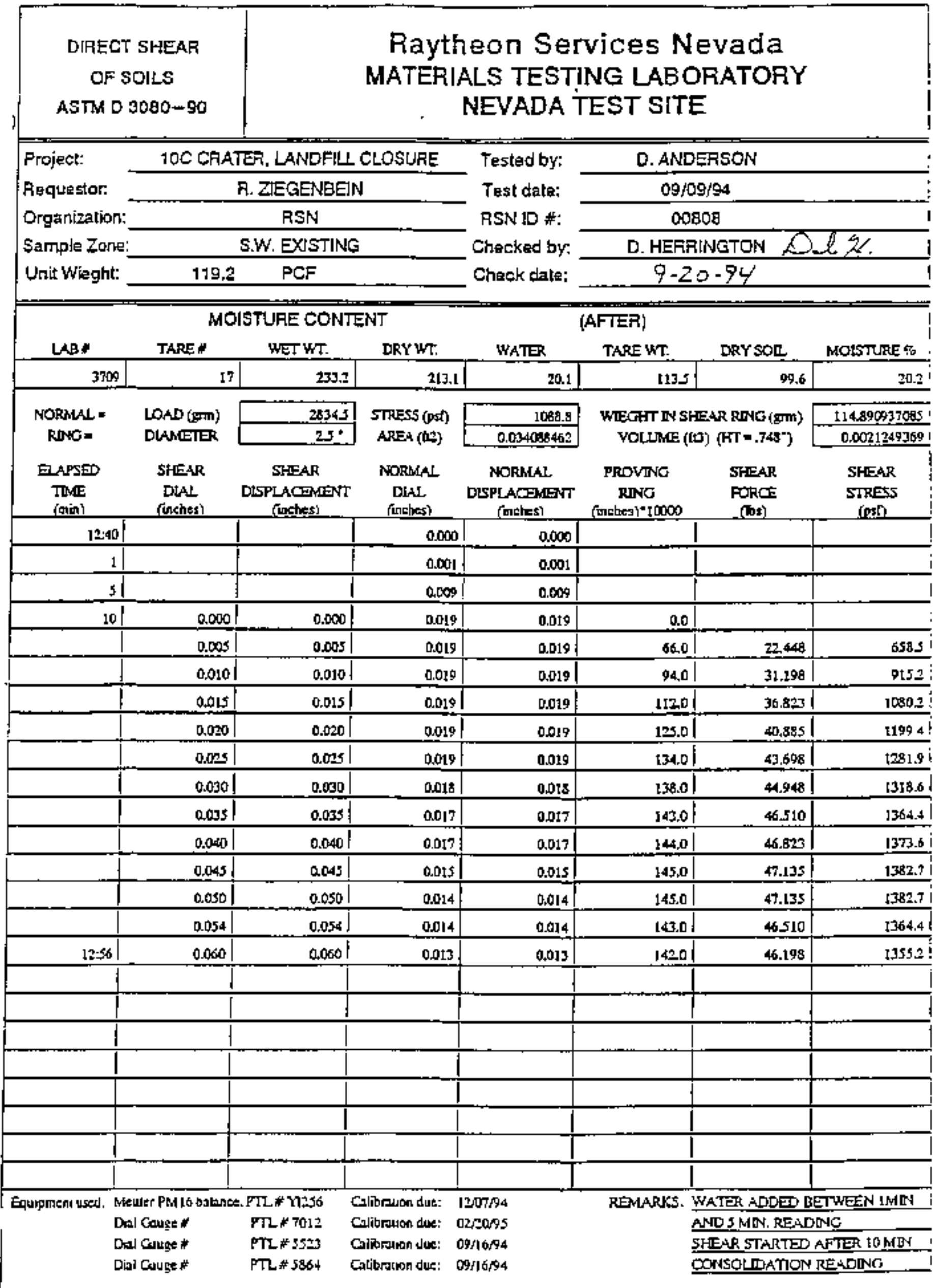




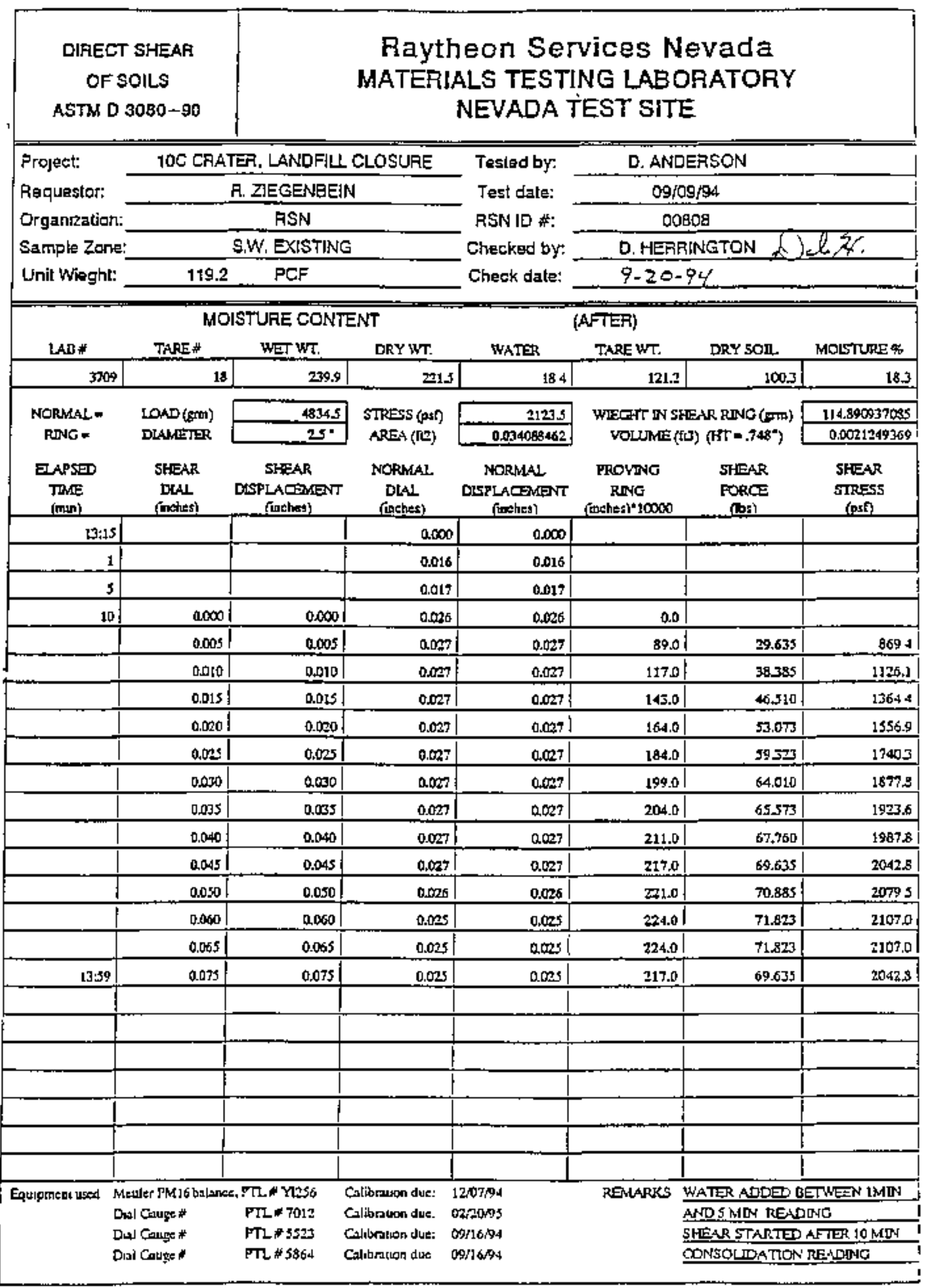




\begin{tabular}{|c|c|c|c|c|c|c|c|}
\hline \multicolumn{2}{|c|}{$\begin{array}{l}\text { DIRECT SHEAF } \\
\text { OF SOILS } \\
\text { ASTM D 3080-90 }\end{array}$} & \multicolumn{6}{|c|}{$\begin{array}{c}\text { Raytieon Services Nevada } \\
\text { MATERIALS TESTING LABORATORY } \\
\text { NEVADA TEST SITE }\end{array}$} \\
\hline Project: & \multicolumn{3}{|c|}{ 10C CRATER, LANDFI CLOSURE } & \multicolumn{4}{|c|}{ D. ANDERSON } \\
\hline Requestor. & \multicolumn{3}{|c|}{ R. ZIEGENBEIN } & \multicolumn{4}{|c|}{$09 / 09 / 94$} \\
\hline Organization: & \multicolumn{3}{|c|}{ RSN } & \multicolumn{4}{|c|}{00908} \\
\hline Sample Zone: & \multicolumn{3}{|c|}{ S.W. EXISTING } & Checked by: & \multicolumn{3}{|c|}{ D. HERAINGTON $\Omega, Q Z$} \\
\hline \multirow[t]{2}{*}{ Unit Wieght: } & 119.2 & \multicolumn{2}{|l|}{ PCF } & Check dale: & \multicolumn{3}{|c|}{$9.20-94$} \\
\hline & \multicolumn{3}{|c|}{ MOISTUAE CONTENT } & \multicolumn{3}{|c|}{ (AFTER) } & \\
\hline LAE $\#$. & TAREF & WET WT. & DRYWT. & WATER & TARE WT. & DRY SOL & MOLSTURE \% \\
\hline 3709 & 10 & 2340 & 215.4 & 18.6 & 115.1 & 1003 & 18 \\
\hline $\begin{array}{l}\text { NORMAL }= \\
\text { RNAG }=\end{array}$ & $\begin{array}{l}\text { LOAD (DRIR) } \\
\text { DTAMEIER }\end{array}$ & $\begin{array}{c}68345 \\
25^{\circ} \\
\end{array}$ & $\begin{array}{l}\text { STRESS (pS?) } \\
\text { AREA (fS) }\end{array}$ & \begin{tabular}{r|}
31.58 .3 \\
0.004005462 \\
\end{tabular} & \multicolumn{2}{|c|}{ 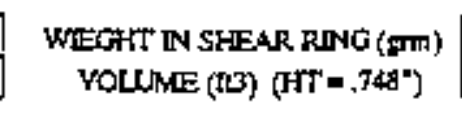 } & $\begin{array}{r}154.890937065 \\
0.0021049369\end{array}$ \\
\hline $\begin{array}{l}\text { DIAPSED } \\
\text { TPME } \\
\text { (miml } \\
\end{array}$ & $\begin{array}{l}\text { SHEAR } \\
\text { DLAL } \\
\text { (inchess) } \\
\end{array}$ & $\begin{array}{l}\text { SHIEAR } \\
\text { DISPLACEMENT } \\
\text { (neltes) }\end{array}$ & $\begin{array}{l}\text { MORHAL } \\
\text { DLAL } \\
\text { fulches) } \\
\end{array}$ & $\begin{array}{l}\text { NOPUhAL } \\
\text { DISPLACEMENT } \\
\text { (inches) }\end{array}$ & $\begin{array}{l}\text { PROVING } \\
\text { RNG } \\
\text { (incheti) } 10000\end{array}$ & $\begin{array}{l}\text { SHEAR } \\
\text { FORTE } \\
\text { (bB) }\end{array}$ & $\begin{array}{c}\text { SHEAR } \\
\text { STRESS } \\
\text { IPSO }\end{array}$ \\
\hline 13:53! & & & 0.000 & 0.000 & & & \\
\hline 1 & & & 0.019 & 0.019 & & & \\
\hline$\$$ & & & 0,021 & 0.001 & & & \\
\hline to! & 0.000 & 0.0001 & $0,02 n$ & 0.02 & 0.0 & & \\
\hline & 0.005 & 0.0051 & 0.0口? & 0.027 & 118.0 & 38.698 & $1135 . ?$ \\
\hline & 0,0101 & 0.010 & 0.008 & 0.029 & 382,0 & 38.698 & 1721.9 \\
\hline & 0.015 & 0.0151 & 0.028 & 0.028 & 203.0 & 71510 & 2097.8 \\
\hline & 0,020, & $0.020 !$ & 0.020 & 0,0 & 260.0 & 83.073 & 24370 \\
\hline & 0.0251 & $0.0 \mathrm{sel}$ & 0.029 & 0.029 & 2720 & 88.385 & 2592.9 \\
\hline & 0.030 & $0,0,030$ & 0,029 & 0.029 & 295.0 & 94.010 & 27578 \\
\hline & 0.035 & 0.035 & 0.029 & 0.029 & 307.0 & $97.760 ?$ & 2867.3 \\
\hline & 0.040 & 0.040 & 0,0029 & 0.009 & 314.0 & $99,948 !$ & 2932.0 \\
\hline & 0,045 & 0.045 & 0.029 & 0.029 & 321.0 & 102.135 & 2996.2 \\
\hline & 0.050 & 0.050 & 0.028 & 0.029 & 323.01 & 102,760 & 30145 \\
\hline & 0.055 & 0.055 & 0.027 & 0.027 & 321.0 & 102.135 & 2996.2 \\
\hline $20: 07$ & 0,06 & 0.065 & 0.027 & 0.027 & 298.0 & 94.948 & 2785 \\
\hline & & & & & & & \\
\hline & & & & & & & \\
\hline & & & & & & & \\
\hline & & & & & & & \\
\hline & & & & & & & \\
\hline & & & & & & & \\
\hline & & & & & & & \\
\hline Eoulpment usred. $\mathrm{N}$ & Neteler Phy 16 balanee & Ae, PTL * YLS6 & Caliberasond due & $1207 / 94$ & REMARKS. W & WATER ADDED BE & ETWEN IMIN \\
\hline & 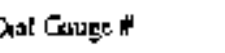 & PTL 7012 & Calibranon dur. & 022085 & & AND $5 \mathrm{MIN}, \mathrm{READ}$ & \\
\hline & Xas| Gouș: " & PTL 5533 & Calkosuan dxe: & $09 / 16,94$ & & SHEMR STARTEO & $A F I E R \quad 10 M \mathbb{N}$ \\
\hline & Aal Collge f & PTL \# \$\$84 & Calibrason usue & $09 / 16 / 94$ & & ONSTLEATION & READING \\
\hline
\end{tabular}




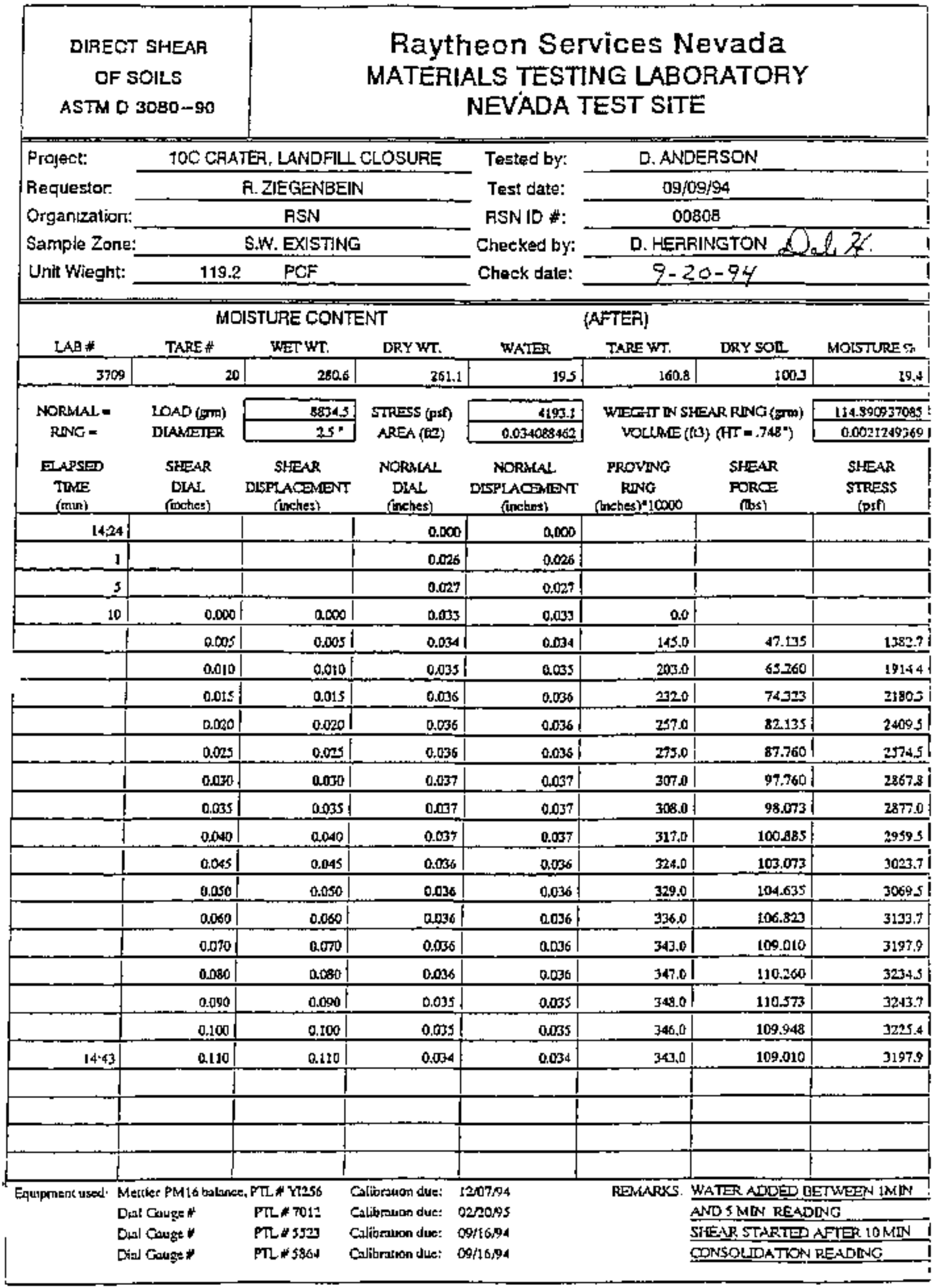




\section{C CRATER (S.E. EXISTING) $10 A 0 * 2834.5$}

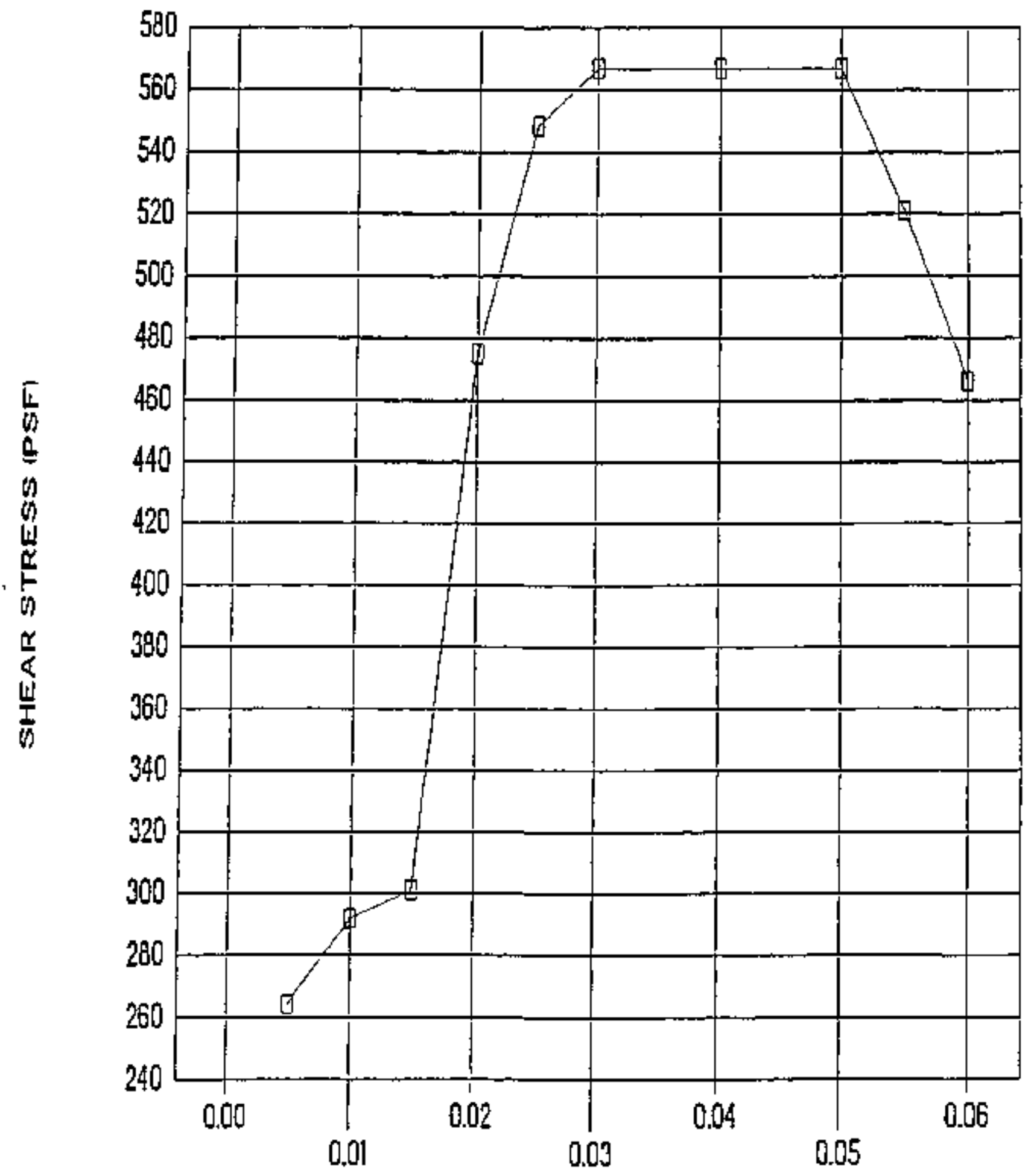

SHEAR DLAL linches' 

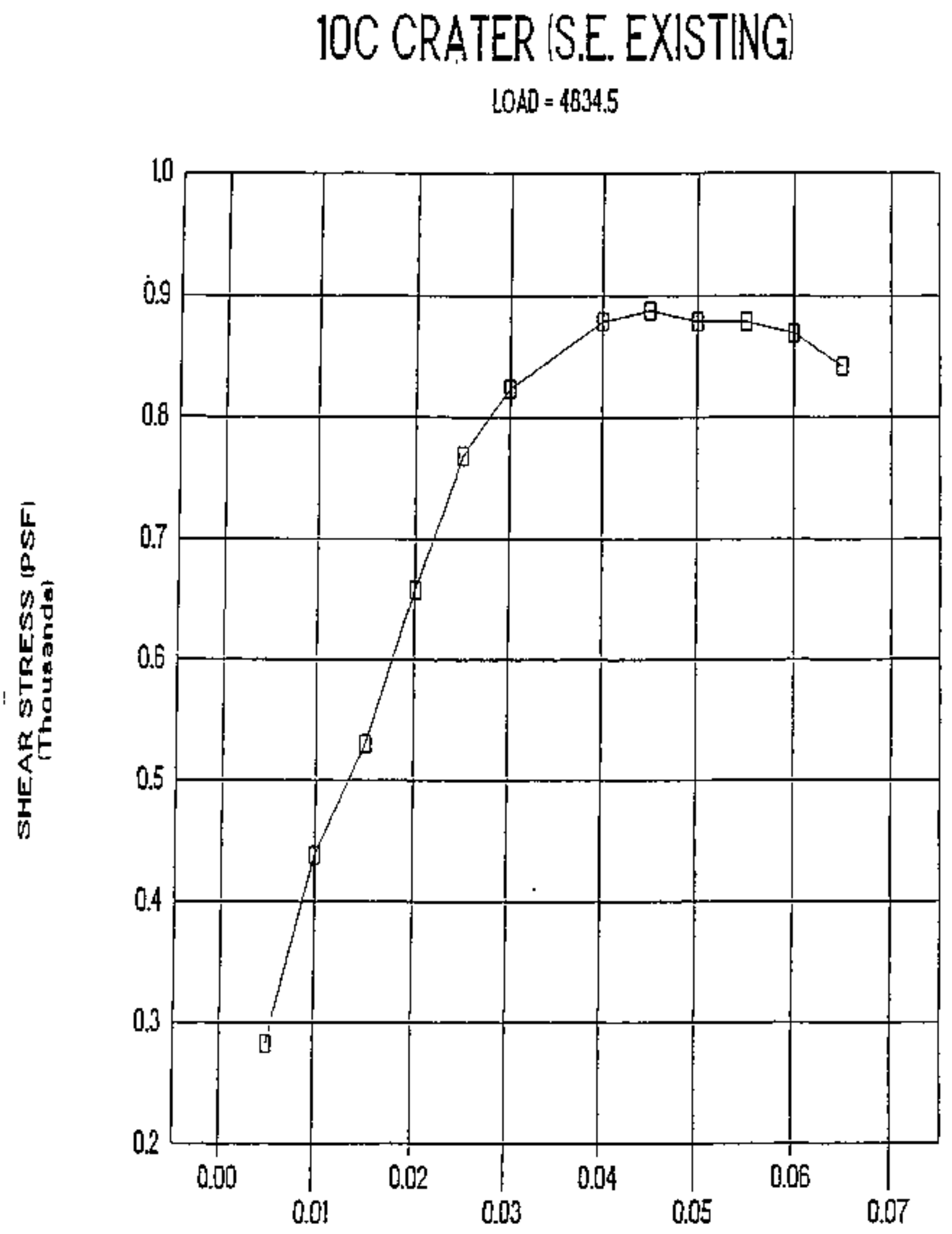

SHEAR DIAL linches' 


\section{OC CRATER (S.E. EXISTING) \\ $\angle O A D=6834.5$}

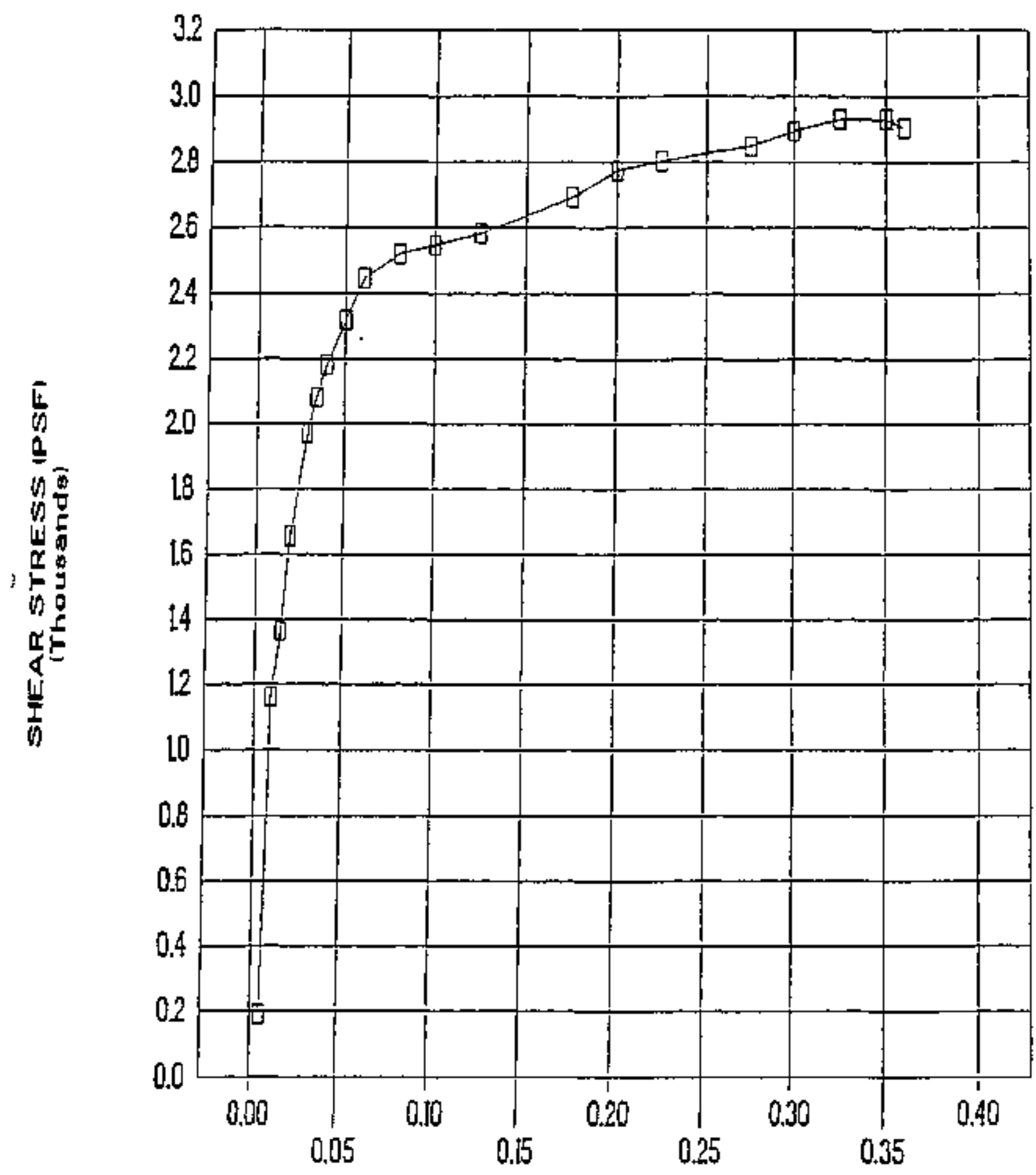

SHEAR OIAL linches? 


\section{IOC CRATER ISE. EXISTING) \\ $\angle O A D=8834.5$}

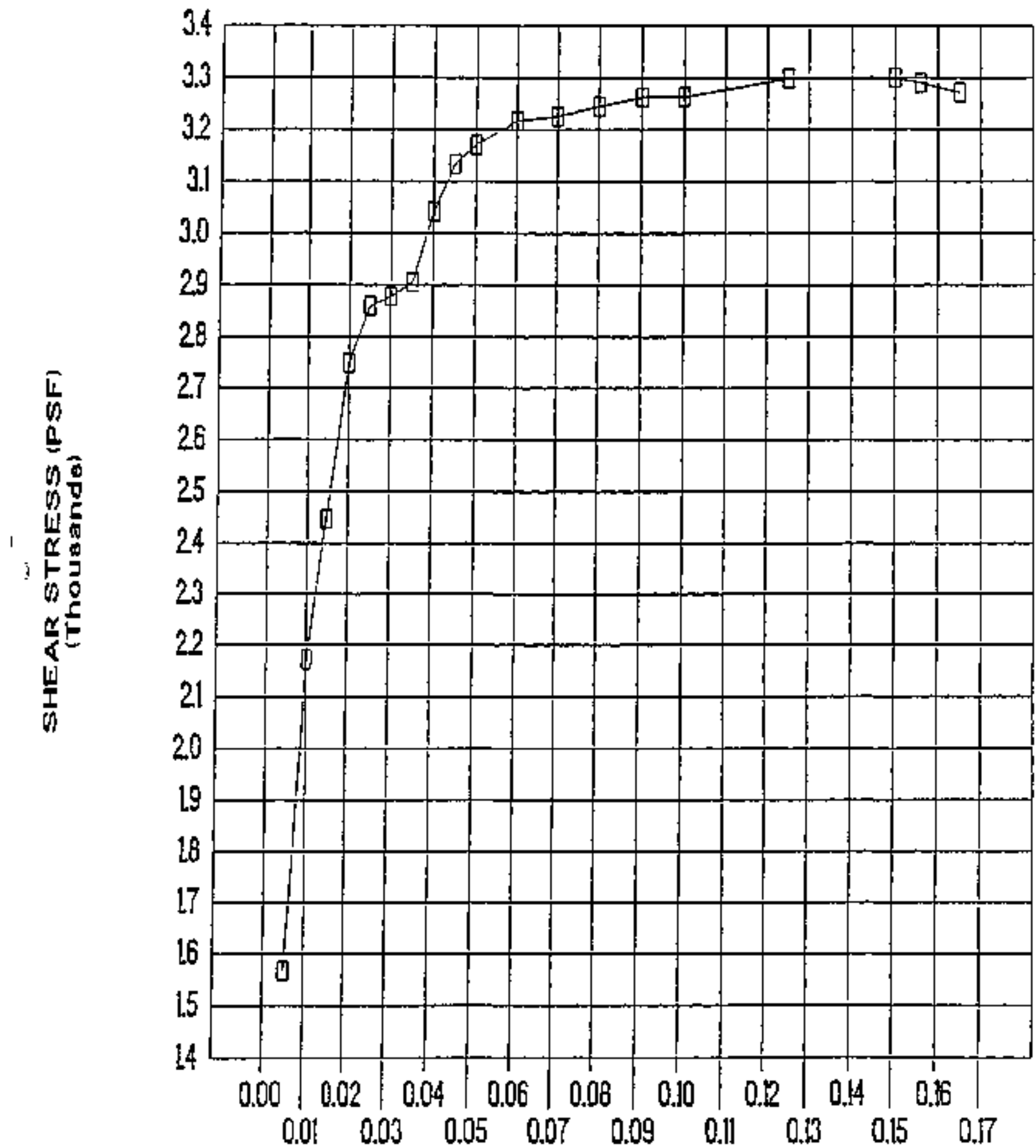

SHEAR DIAL Finches! 


\section{C:CRATER (NE. EXISTINGI \\ $\angle O A D=2 B 34.5$}

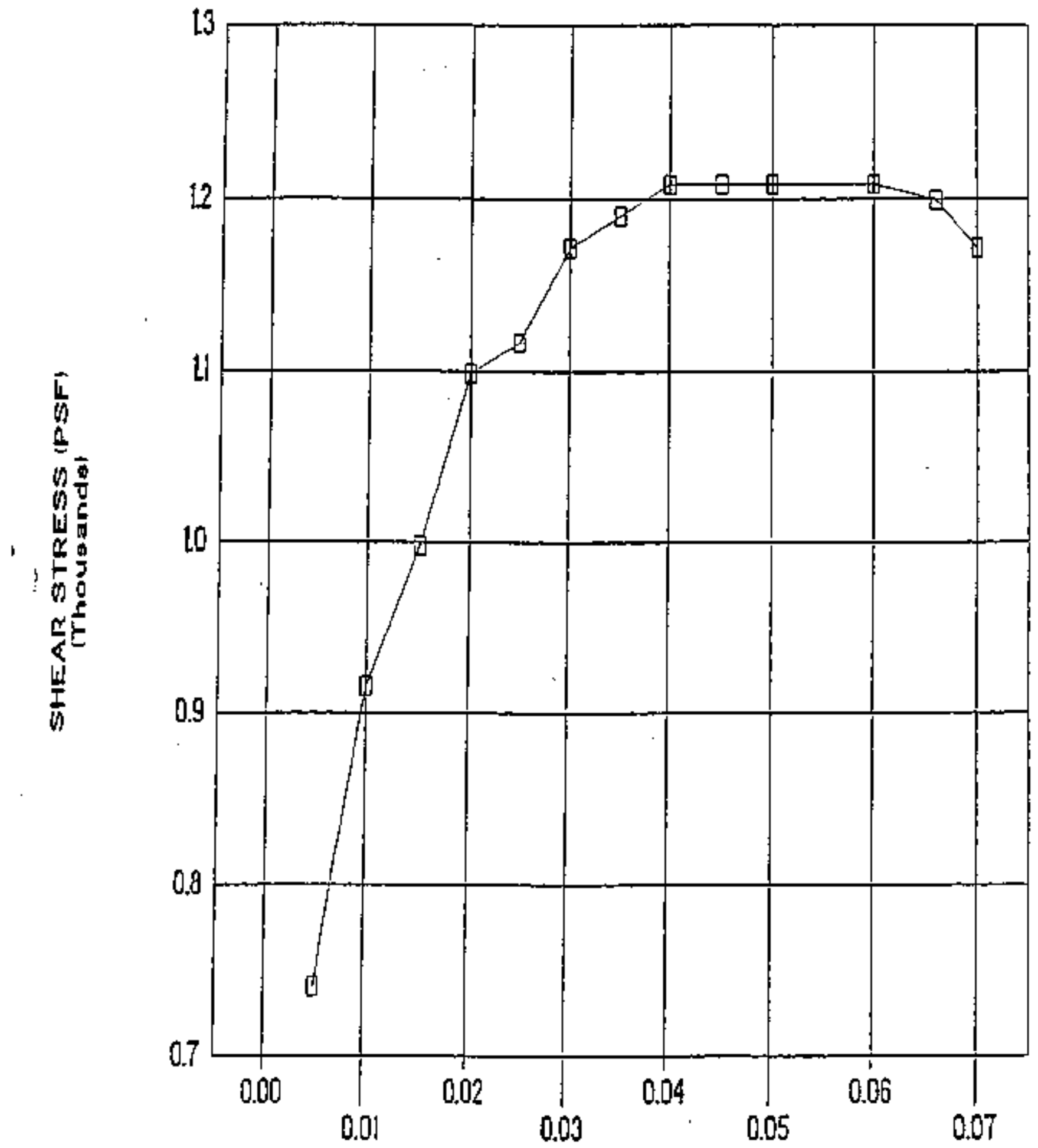

SHEAR D|ALL linches] 


\section{IOC CRATER (NE EXISTING) $\angle O A D=4834.5$}

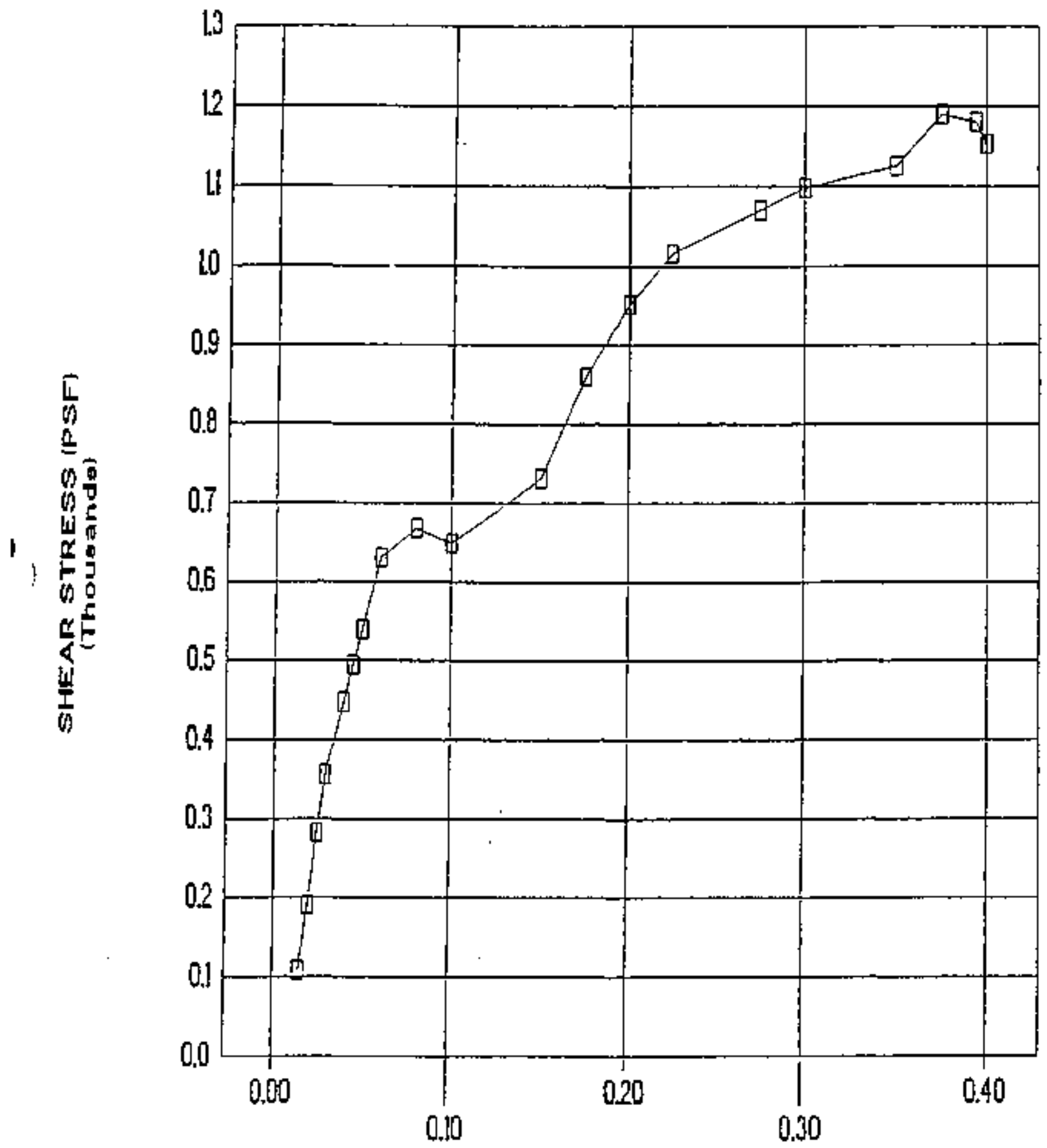

SHEAR DIAL thinches? 


\section{C CRATER (NE. EXISTINGI $20 A D=6834.5$}

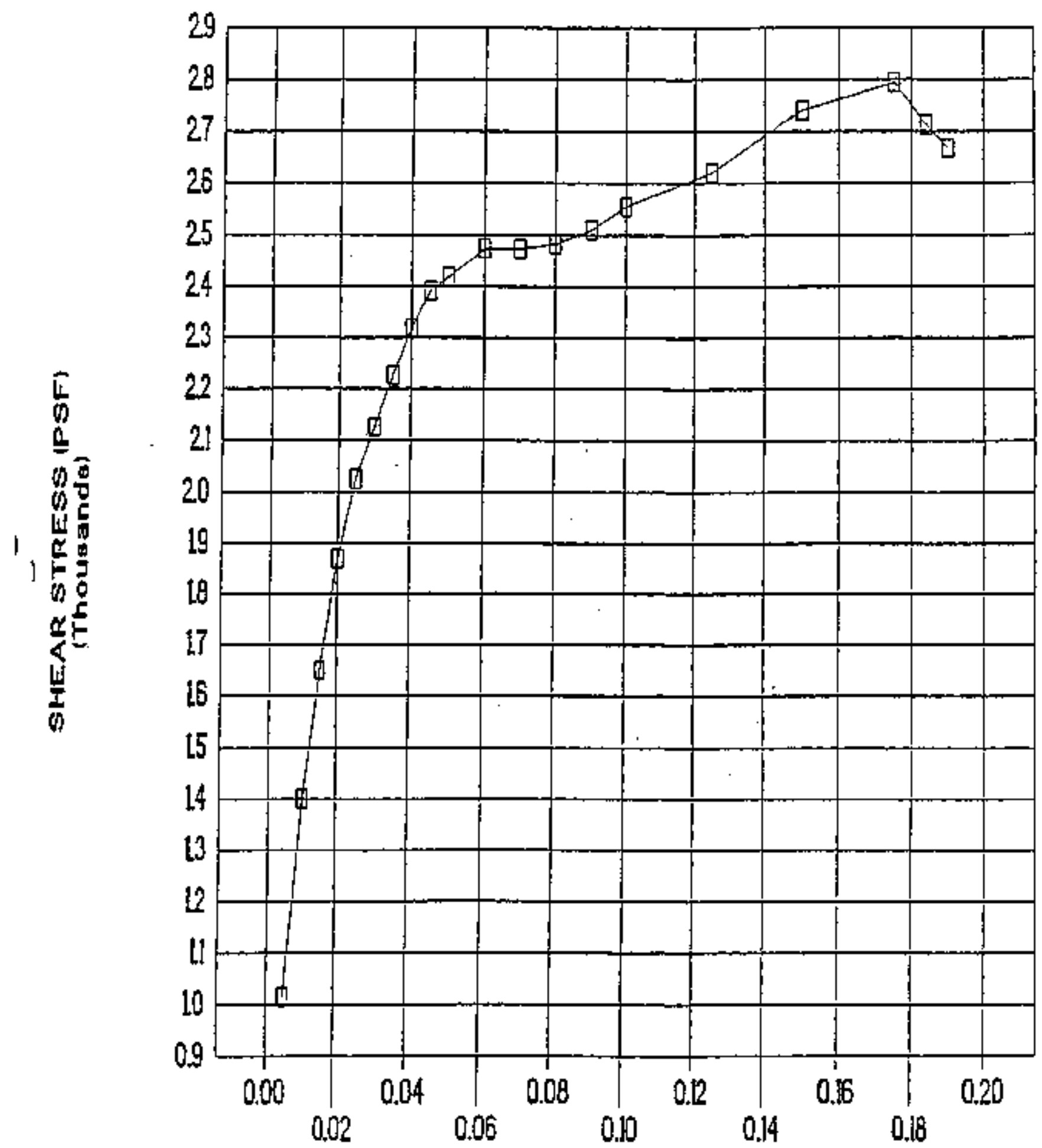

SHEAR DIAL linchesi 
: $\quad$ IOC CRATER (N.E. EXISTING)

$\angle O A D=8834.5$

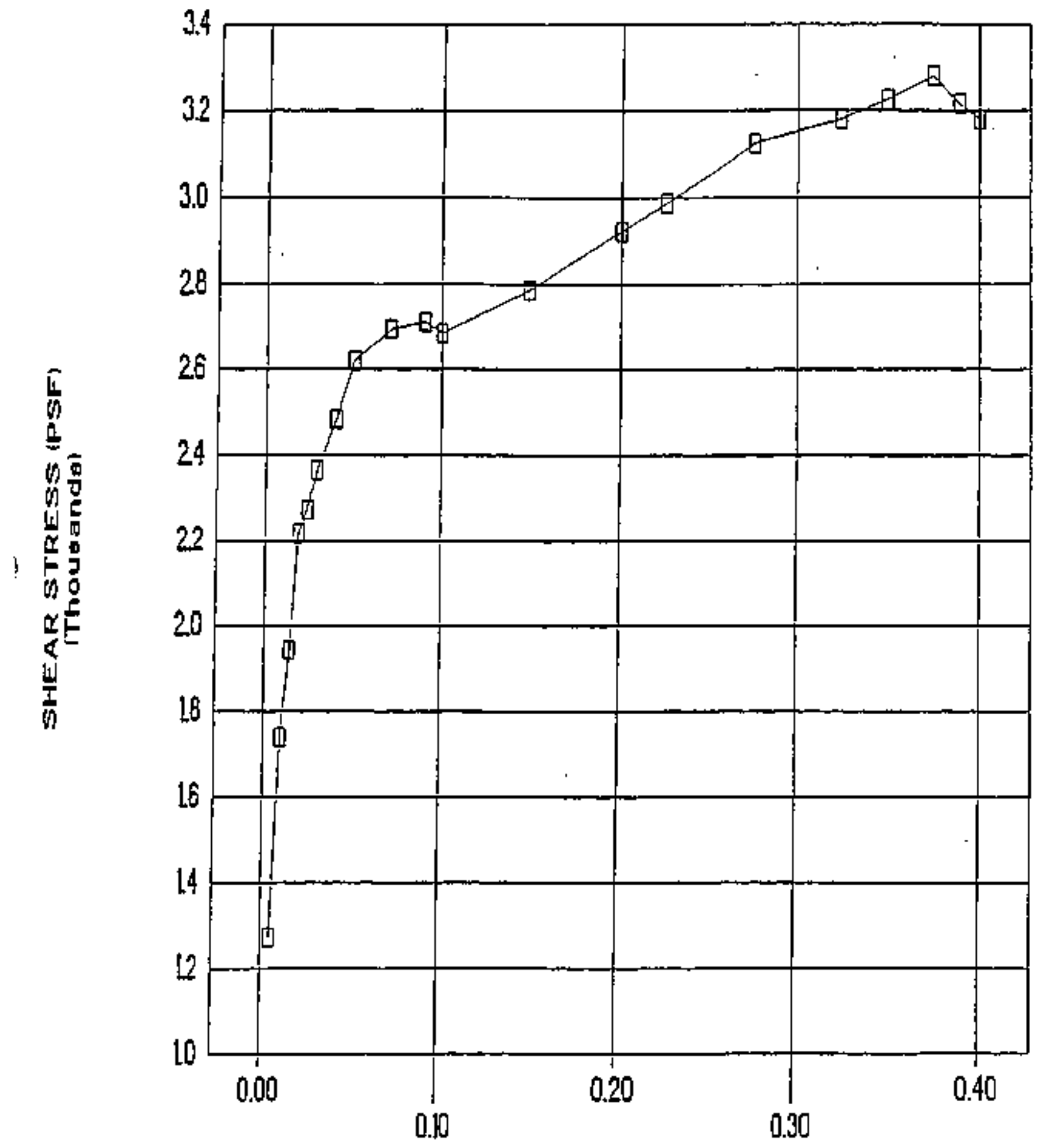

SHEAR DIAL linchess) 


\section{- TOC CRATER N.W. EXISTINGI $10 A 0=2834.5$}

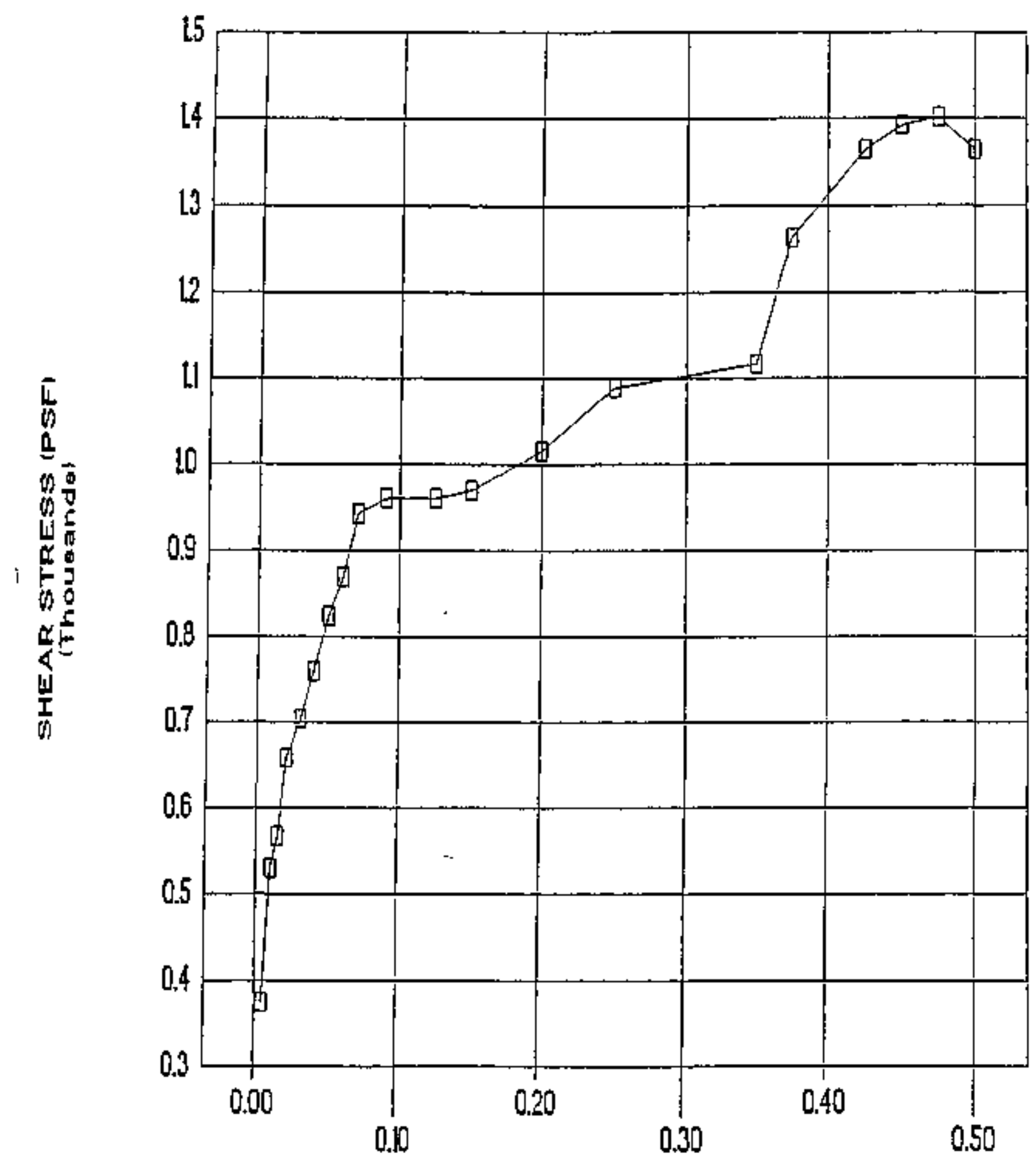




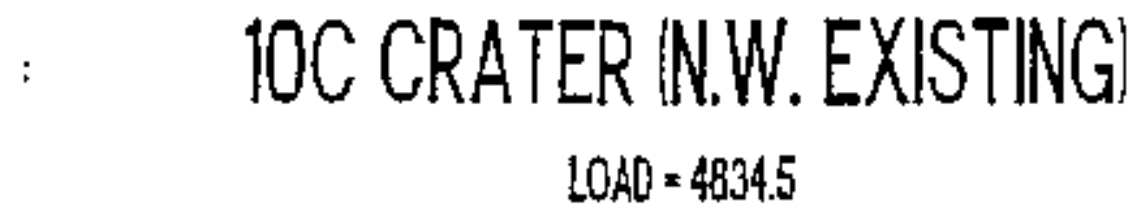

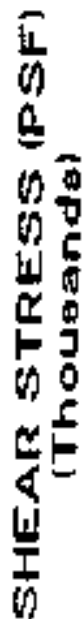

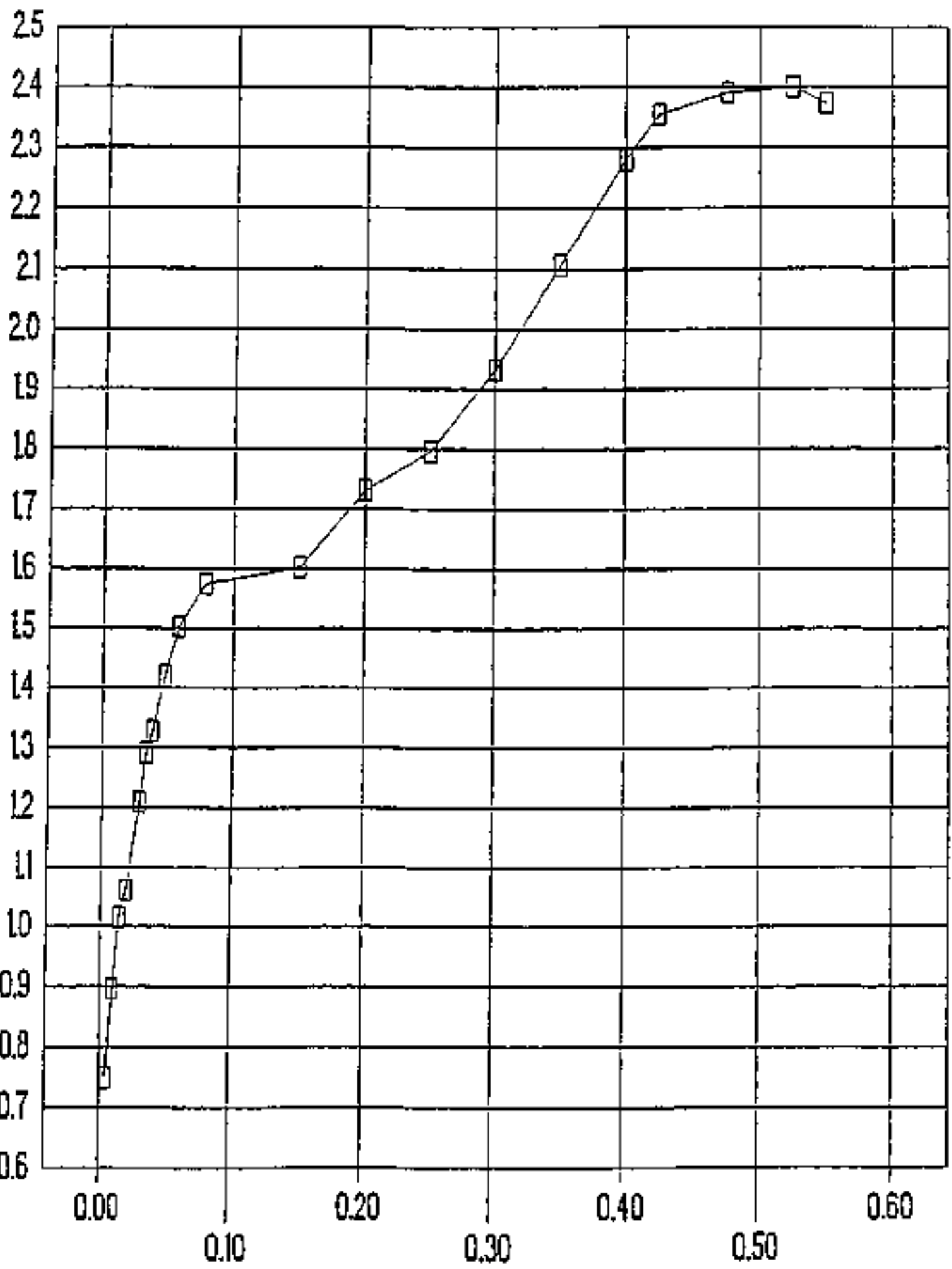

SHEAR DIAL linchest 


\section{IOC CRATER (N.W. EXISTING) $1040=6834.5$}

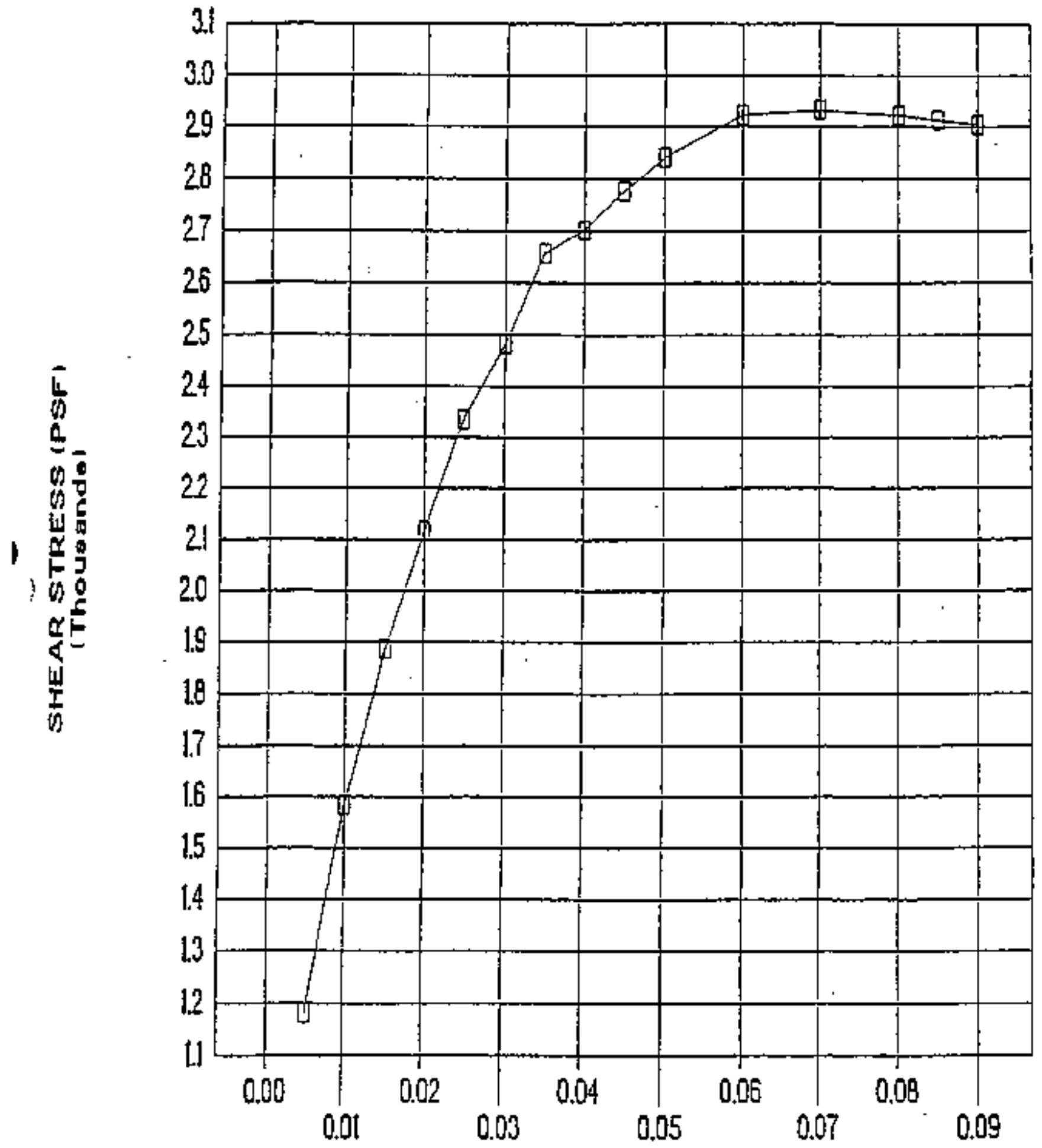

SHEAR DIAL linches\} 


\section{IOC CRATER (N.W. EXISTING) $\angle O A D=6834.5$}

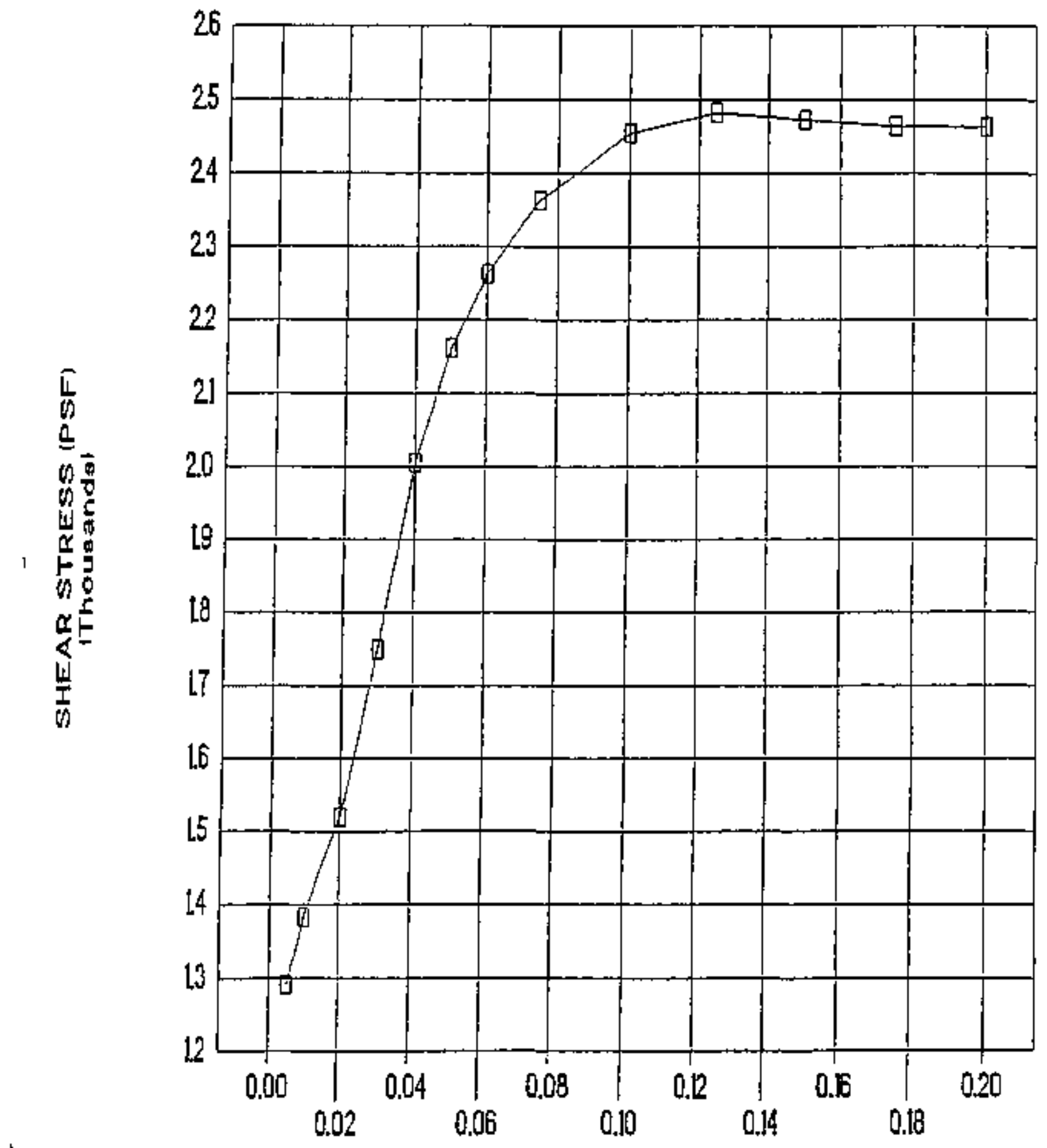

SHEAR DIAL linches 


\section{OCCRATER IS.W. EXISTING) \\ $\angle O A D=2834.5$}

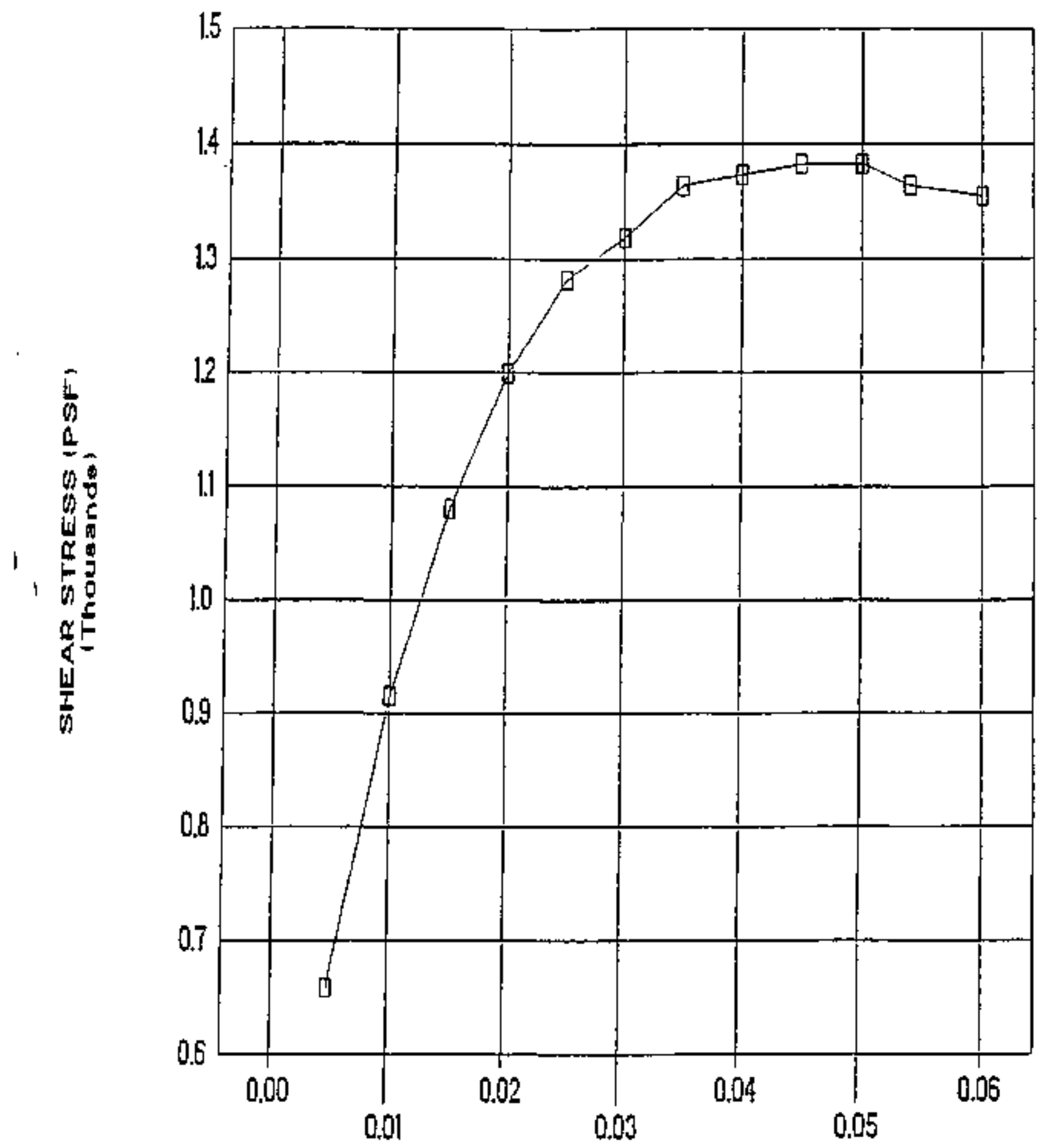

SHEAR DIAL linches] 
1OCCRATER (S.W. EXISTING)

$\angle O A D=4634.5$

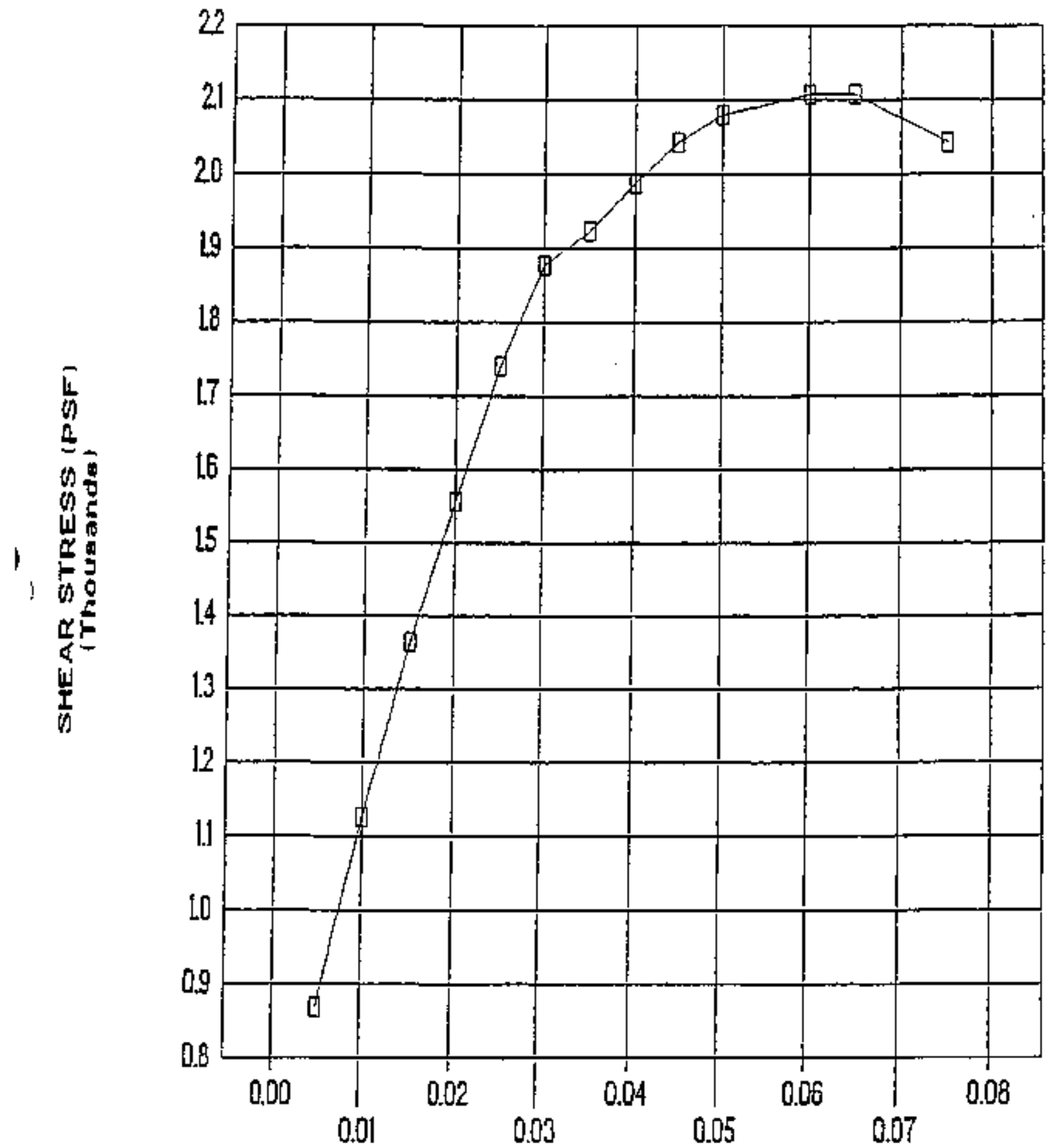

SHEAR OIAL linches\} 


\section{OC CRATER IS.W. EXISTINGI $\angle O A D=6834.5$}

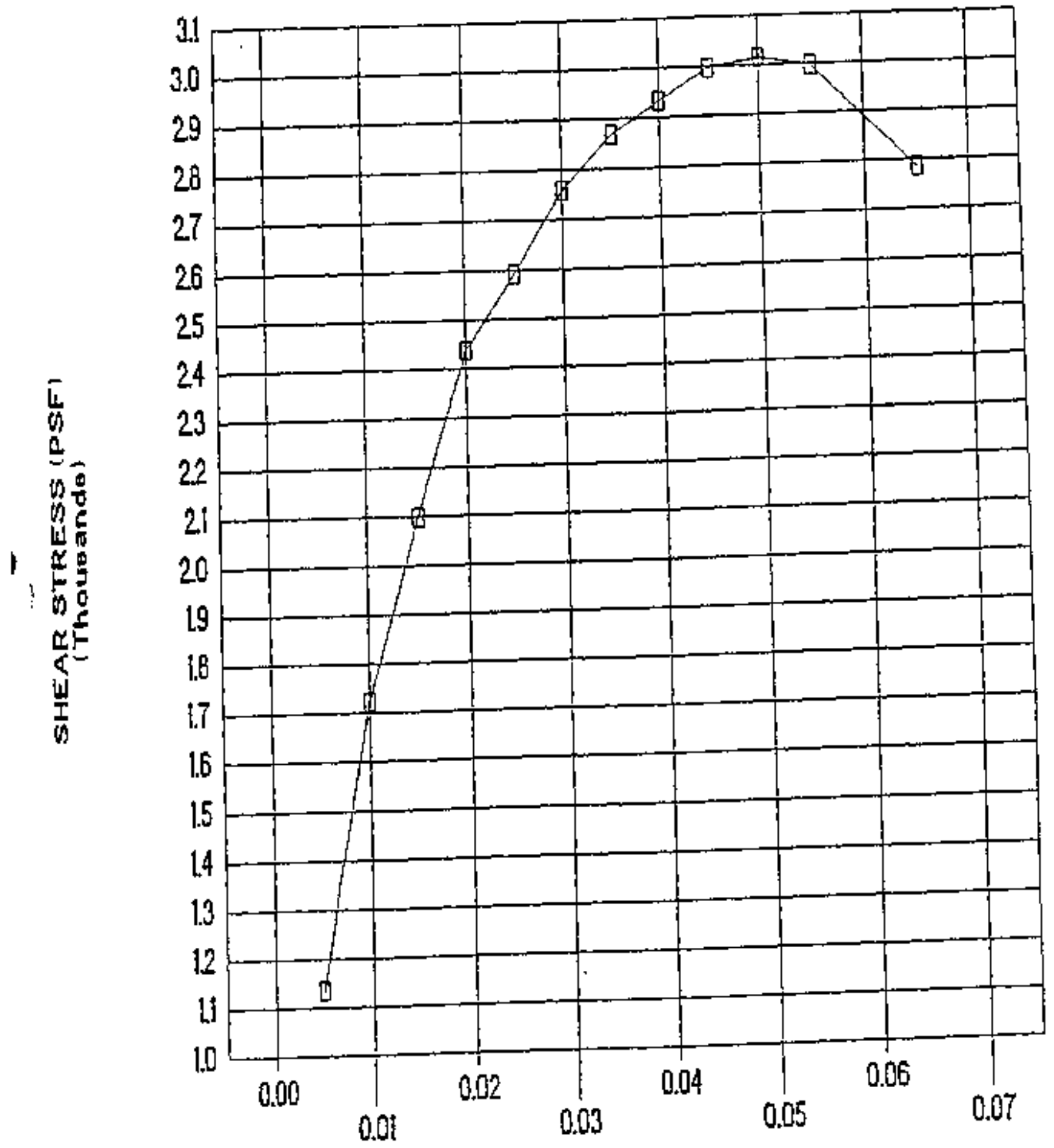

SHEAR DIAL linches! 


\section{OCCRATER IS.W. EXISTING) \\ $\angle O A D=8834.5$}

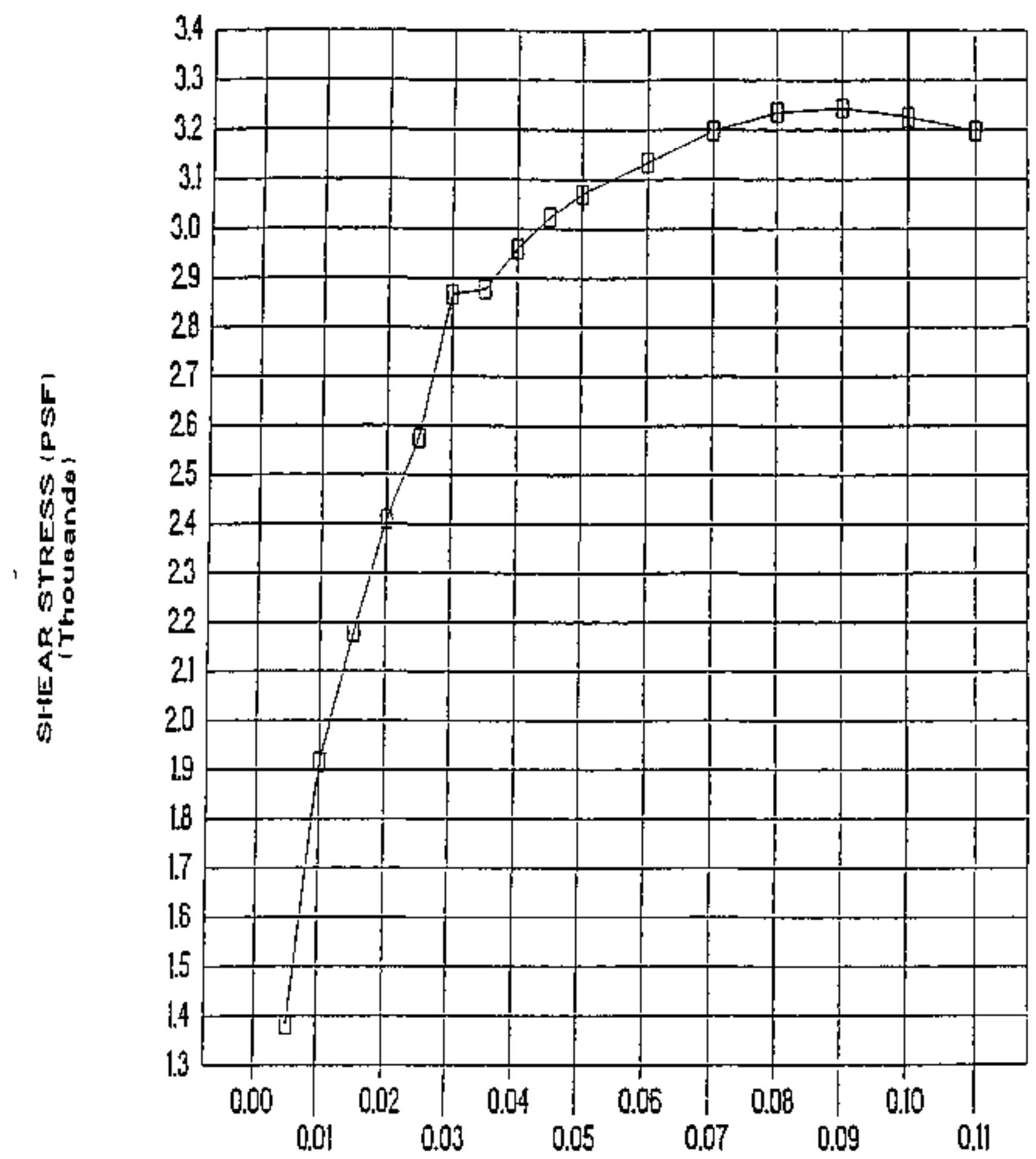

SHEAR DiAL linches! 


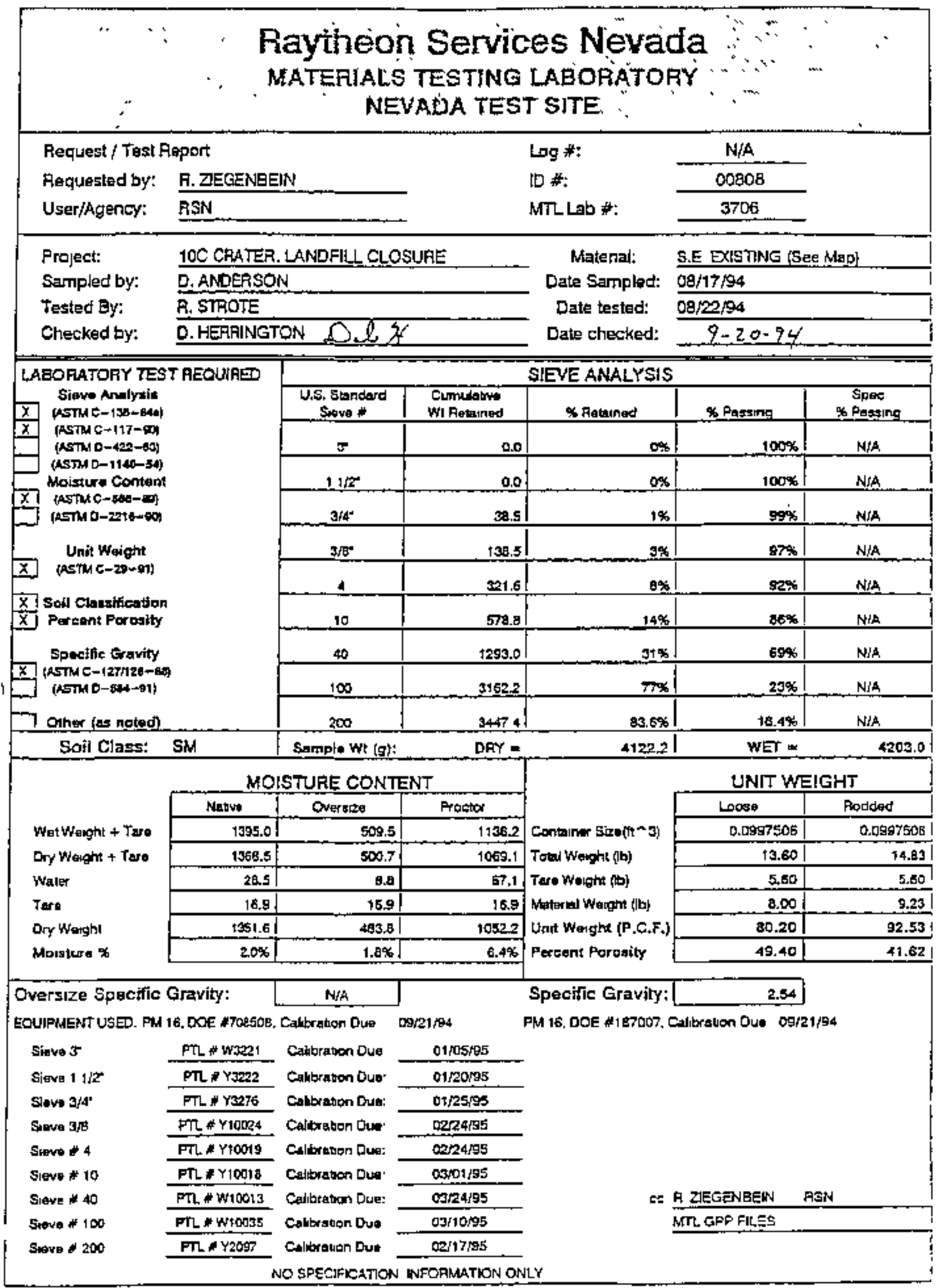




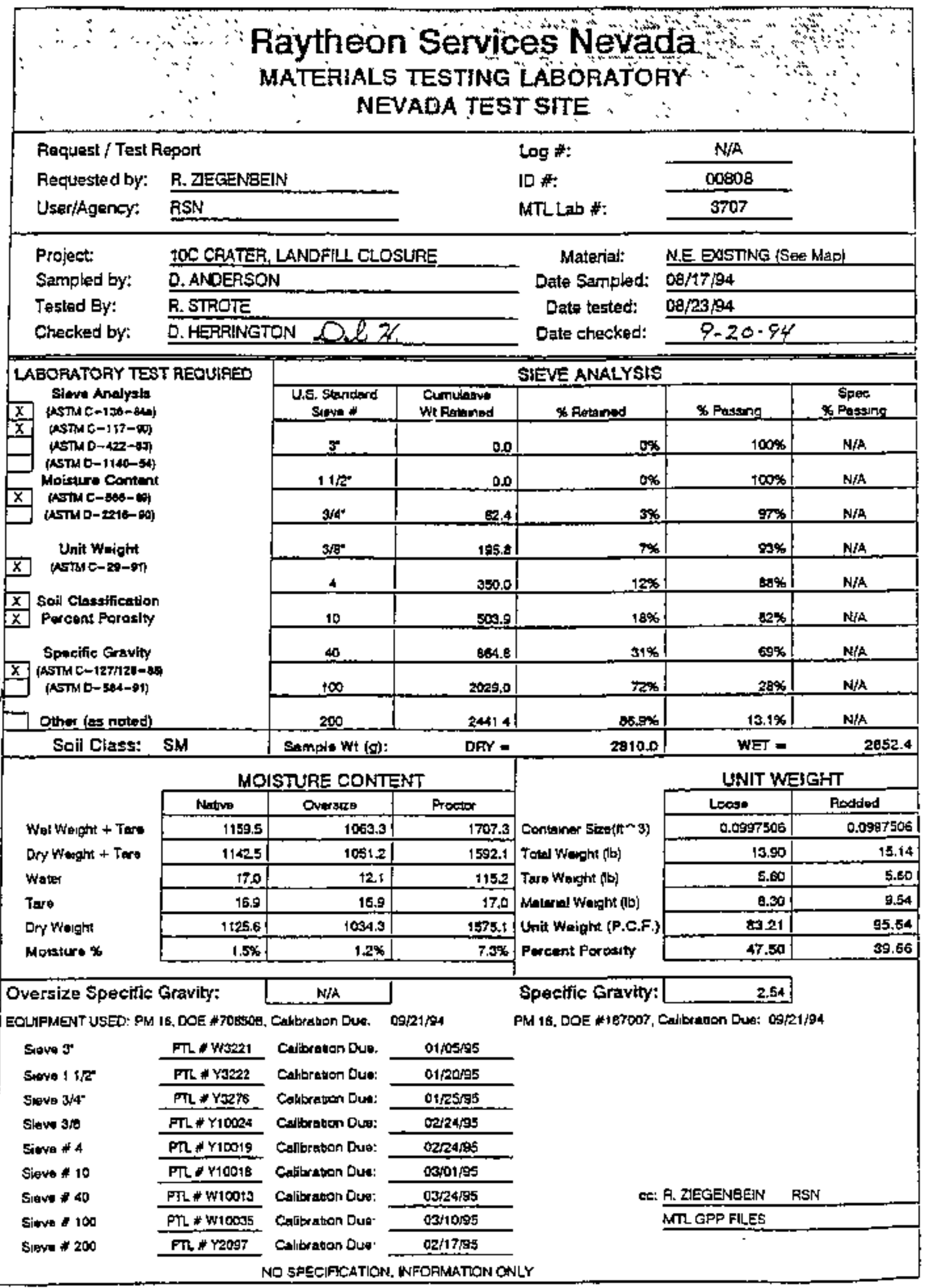




\section{Raytheon Services.Nevada MATERIALS TESTING LABORATORY NEVADA TEST SITE}

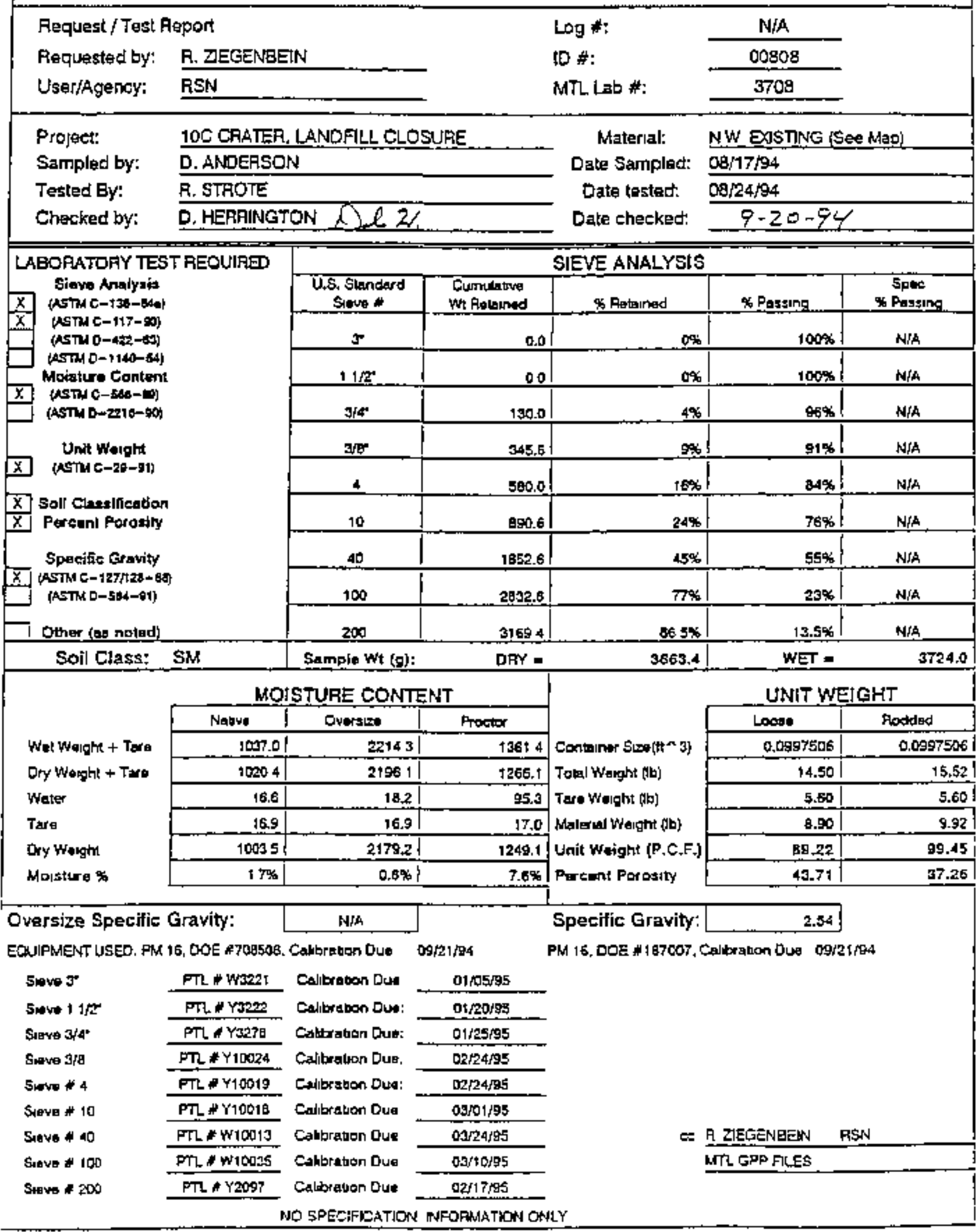




\section{Raytheon Services Nevada \\ MATEFIALS TESTING LABORATORY NEVA'DA TEST SITE}

Request / Test Report
Requested by:
User/Agency;

$\log \#$

ID \#:

MTLL \#:

Materiad:

Date Sampled:

Date tested:

Date checked:

$\frac{N / A}{00808}$

5.W EXSTNGG isoe Maol

$0 \mathrm{~g} / 17 / 94$

$08 / 25 / 94$

\begin{tabular}{|c|c|c|c|c|c|}
\hline LABORATORY TEST AEOUIAED & & & VE ANALYSIS & & \\
\hline 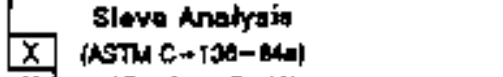 & $\begin{array}{l}\text { U.S. Stondard } \\
\text { Srave* }\end{array}$ & $\begin{array}{c}\text { Cumulative } \\
\text { Wh Retheined }\end{array}$ & \% Fotanned & \% Passyng & $\begin{array}{l}\text { Sper } \\
\text { Xossong }\end{array}$ \\
\hline$x$ (NSTN D-420-63) & 3 & 0.0 & $\mathbf{D}$ & $100 \%$ & $\mathrm{~N} / \mathrm{A}$ \\
\hline Moistur Candest & $11 / 2$ & 210.2 & $5 \%$ & $94 \times$ & $N / A$ \\
\hline I ASTM D-2210-8) & $3 / 4 \cdot$ & 330.7 & toges & $90 \%$ & N/h \\
\hline Unil Woipht & 3r: & 475.6 & $14 \%$ & $86 \%$ & N/K \\
\hline (ASTSC-29-81) & 4 & 525.6 & $19 \%$ & B1\% & N/A \\
\hline$\frac{x}{x}$. Fachent Pordosity & 10 & $\$ 01.0$ & $24 \%$ & $76 \%$ & Ni/A. \\
\hline Speatic Gravity & 40 & 1475.5 & $45 \%$ & $55 \%$ & N/A \\
\hline (a)th 0-5ac-o1) & 100 & 2484,8 & $75 \%$ & $25 \%$ & Nith \\
\hline Ather (as noted) & 200 & 2880.3 & $97.5 \%$ & $12.5 x$ & N/A \\
\hline Soll Class: SM & Sampie Wt (g) & DAY $\approx$ & 3291,5 & $W E=$ & \\
\hline
\end{tabular}

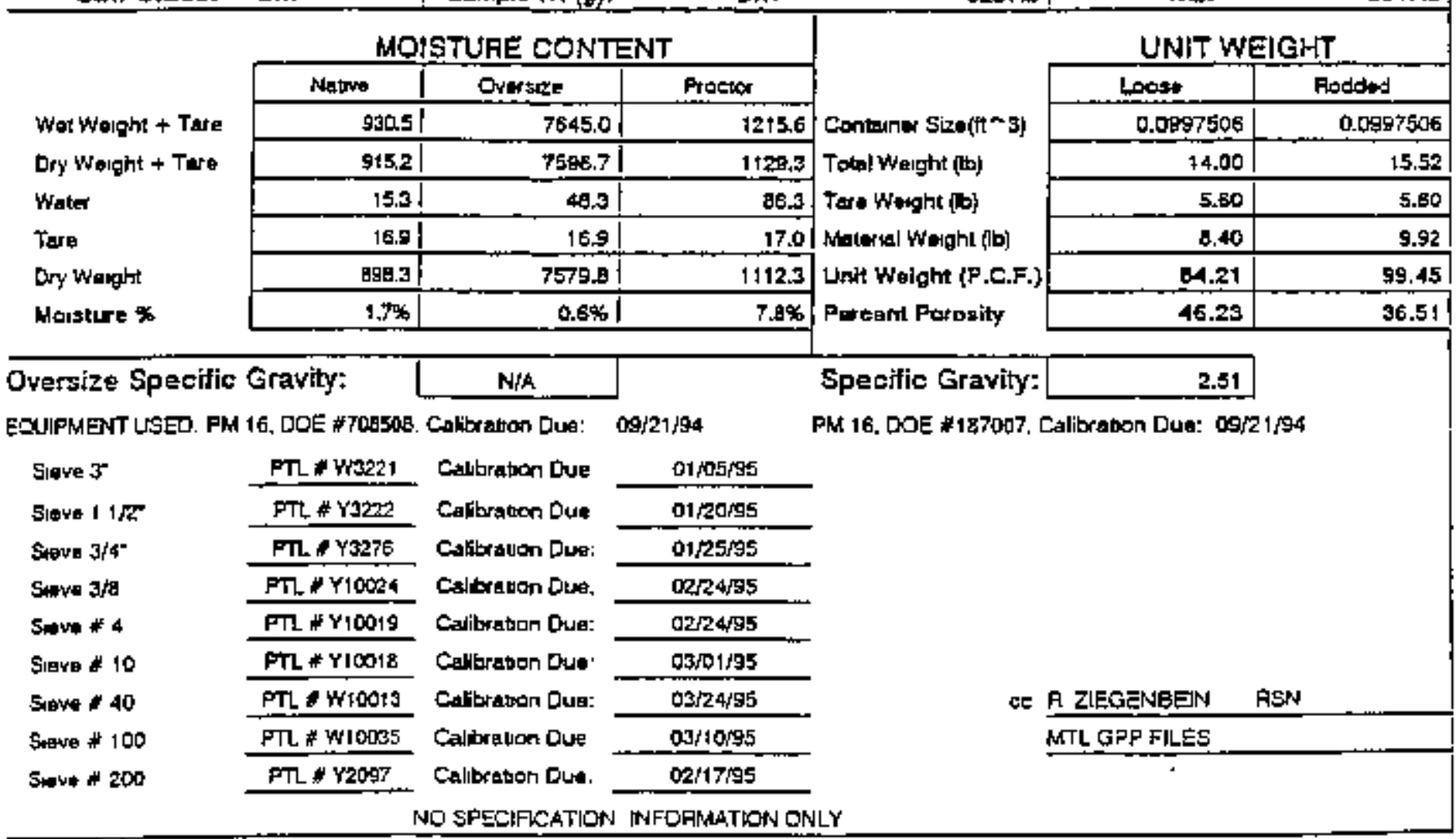


TABLE 1. COMPOSITYON OF HYDROMETER (ASTM D422-90)

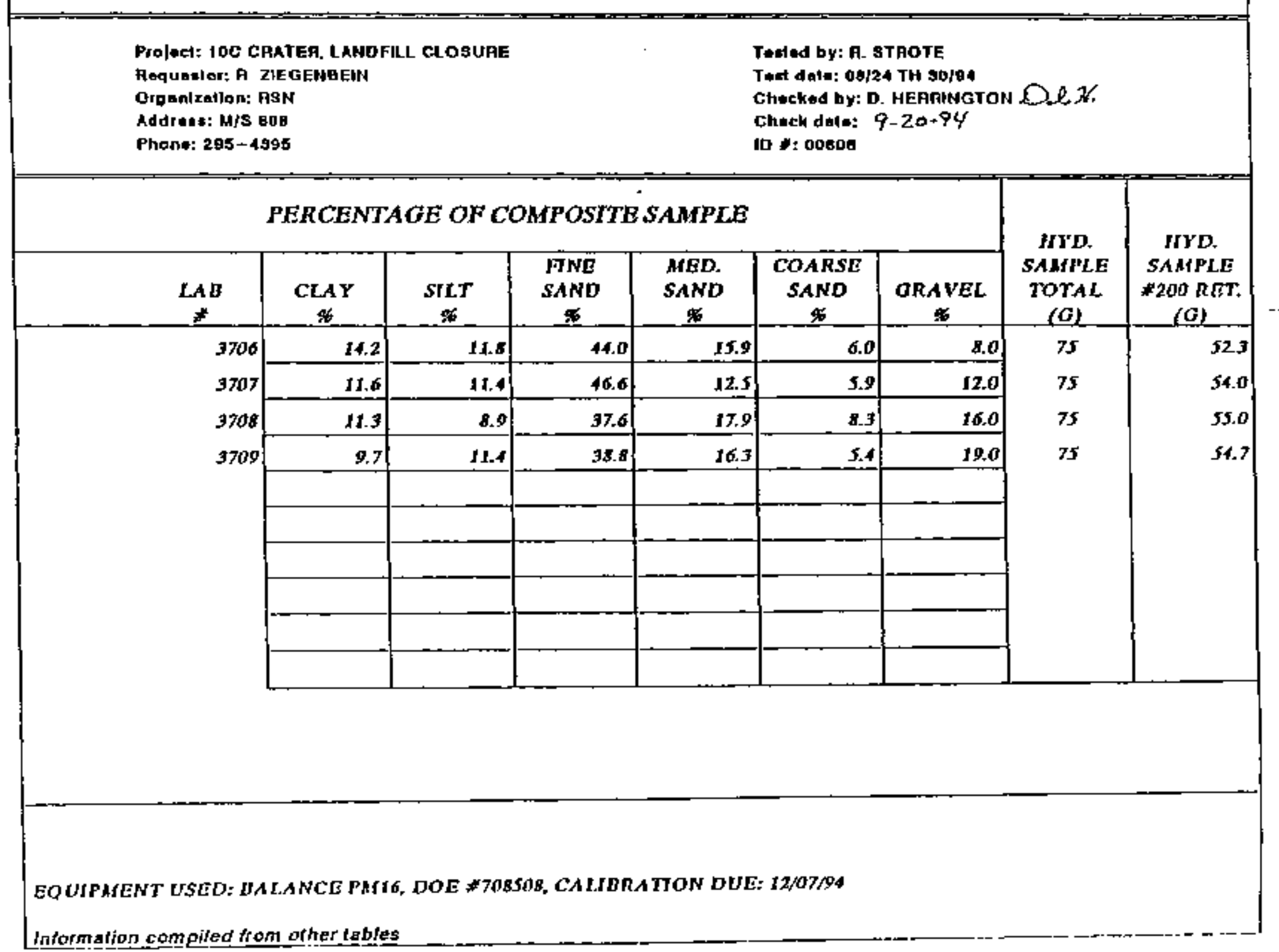


TADLE 2. PARTICLE-SIZE DETERMINATION BY ISZH IIYDROMETER (ASTM D422-9O)

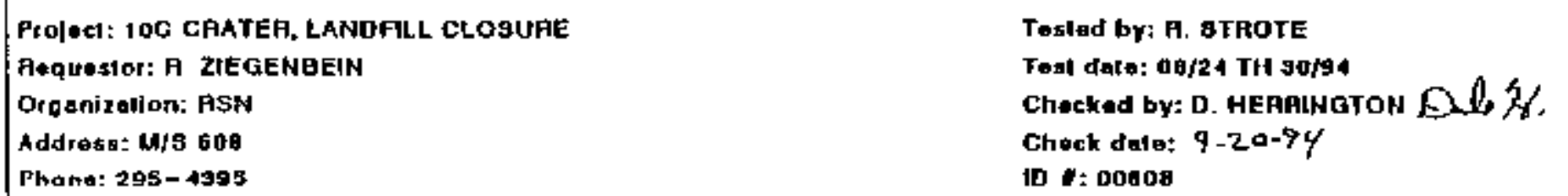

Phatra: 295-4995

\begin{tabular}{|c|c|c|c|c|c|c|c|c|c|c|}
\hline \multicolumn{2}{|c|}{ Vonable $=-\infty 3$} & \multicolumn{2}{|l|}{$\mathbf{T}$} & \multirow{2}{*}{ Corrected } & \multirow{2}{*}{$\begin{array}{c}\text { P. "Y" } \\
\text { Bolf In } \\
\text { Suspention }\end{array}$} & \multirow{2}{*}{ L } & $\begin{array}{c}\text { n } \\
\text { gP27 Waler }\end{array}$ & $\begin{array}{c}K \\
\text { D422 }\end{array}$ & \multirow{2}{*}{$\begin{array}{l}\text { D. "x" } \\
\text { Parnelo } \\
\text { Diameles } \\
\text { fmm }\end{array}$} & \multirow[b]{2}{*}{$\cdot$} \\
\hline Lab & $\begin{array}{l}\text { Wales } \\
\text { Temp } \\
\text { (C) }\end{array}$ & $\begin{array}{l}\text { Time ol } \\
\text { Feading } \\
\text { imin| }\end{array}$ & $\begin{array}{c}\text { Hyde ompis } \\
\text { Reachng } \\
\text { (aA) }\end{array}$ & & & & $\begin{array}{c}\text { AP2T Waler } \\
\text { Viscoefiy } \\
\text { (poldep }\end{array}$ & $\begin{array}{c}\text { D422 } \\
\text { Tabie } 3 \\
\text { Condunt } \\
\end{array}$ & & \\
\hline \multirow[t]{8}{*}{3708} & 270 & 1 & 250 & 250 & 295 & 122 & (1) 00851 & 001302 & 00455 & $254-B=3 G$ of soll patilides (g/ee) \\
\hline & 27 a & 2 & 200 & 200 & 236 & 130 & 000051 & $0 \pm 1502$ & 00332 & $7500=\mathrm{Nr}-d r y$ mate of lotal ool semple fal \\
\hline & 270 & 5 & 170 & 170 & 200 & 135 & 000051 & 001302 & 00214 & 6596 m Percerse of tolat tok asmple pasalng * 10 \\
\hline & 265 & 15 & 110 & 140 & 165 & $\$ 40$ & a 00881 & 001309 & 00126 & 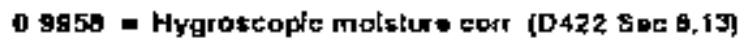 \\
\hline & 265 & 90 & 135 & 135 & 159 & 141 & 000851 & 001309 & 00090 & $1.02=1=\mathrm{SG}$ correalon [D422 Tetle 1 ) \\
\hline & 260 & Bo & 126 & 125 & 147 & 143 & 0 oodro & 001318 & 00064 & $1.000=01$ - $\$ 9$ of eugpendlns medtum (o/ec) \\
\hline & 270 & 250 & 110 & 110 & 130 & 145 & o oonst & n 01302 & 00031 & 86 as $=W=$ Ovan-firy trask of tatal soll samplo \\
\hline & 250 & 1440 & 90 & 90 & 100 & 148 & D $0099 a$ & 001331 & 00014 & cop by mass at sall dlsparsed |gl \\
\hline
\end{tabular}




\section{TABLE 2. PARTICLE-SIZE DETERMINA TYON BY 152H HYDROMETER (ASTM D422-9O)}

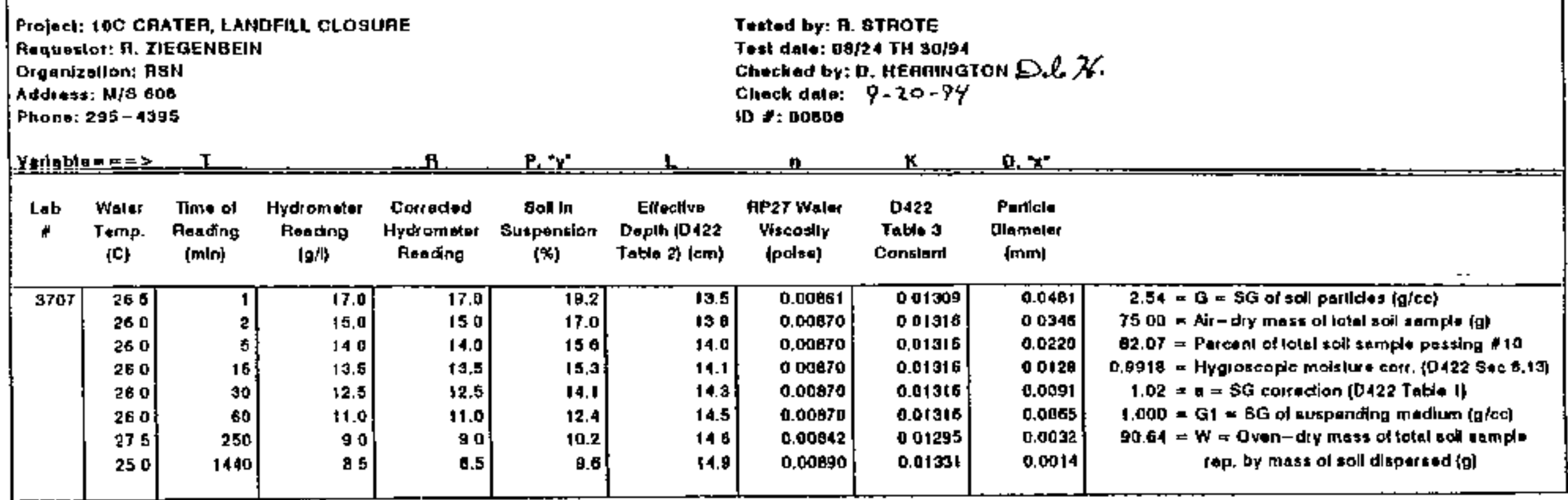




\section{TABLE 2. PARTICLE-SIZE DETERMINATION BY 15ZH HYDROMETER (ASTM D422-9O)}

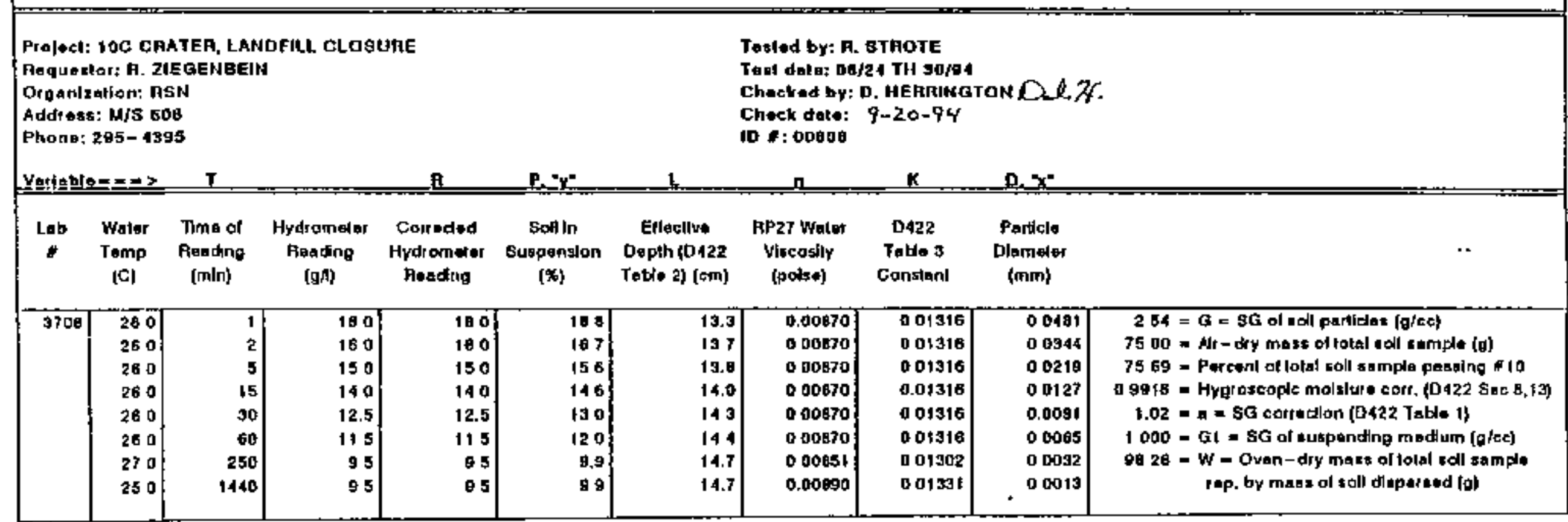

Equipment Used. Balahte. FH400 DOE * 700507, Cahbration Dut; 09/21/94

PAg 3 of 4 


\section{TABLE 2. PARTICLE-SIZE DETERMINATION BY 1SZH HYDROMETER (ASTM D422-90)}

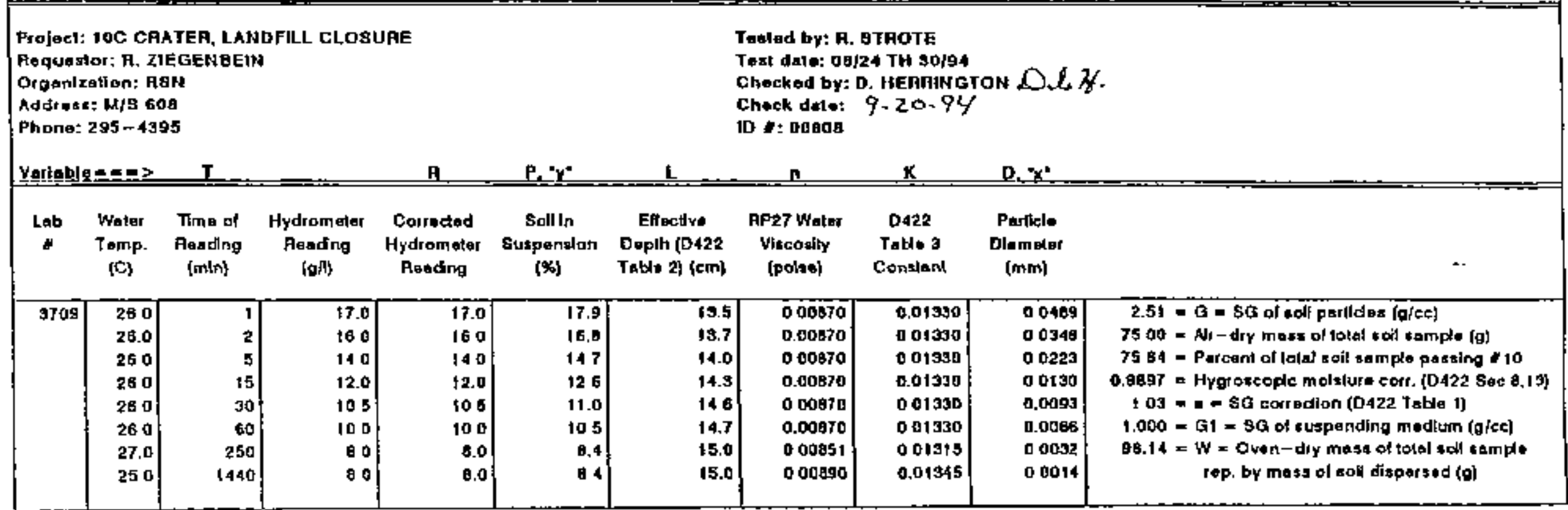


TABLE 3. PARTICLE - SIZE ANALYYSIS OF SOILS (HYDROMETER) D 422

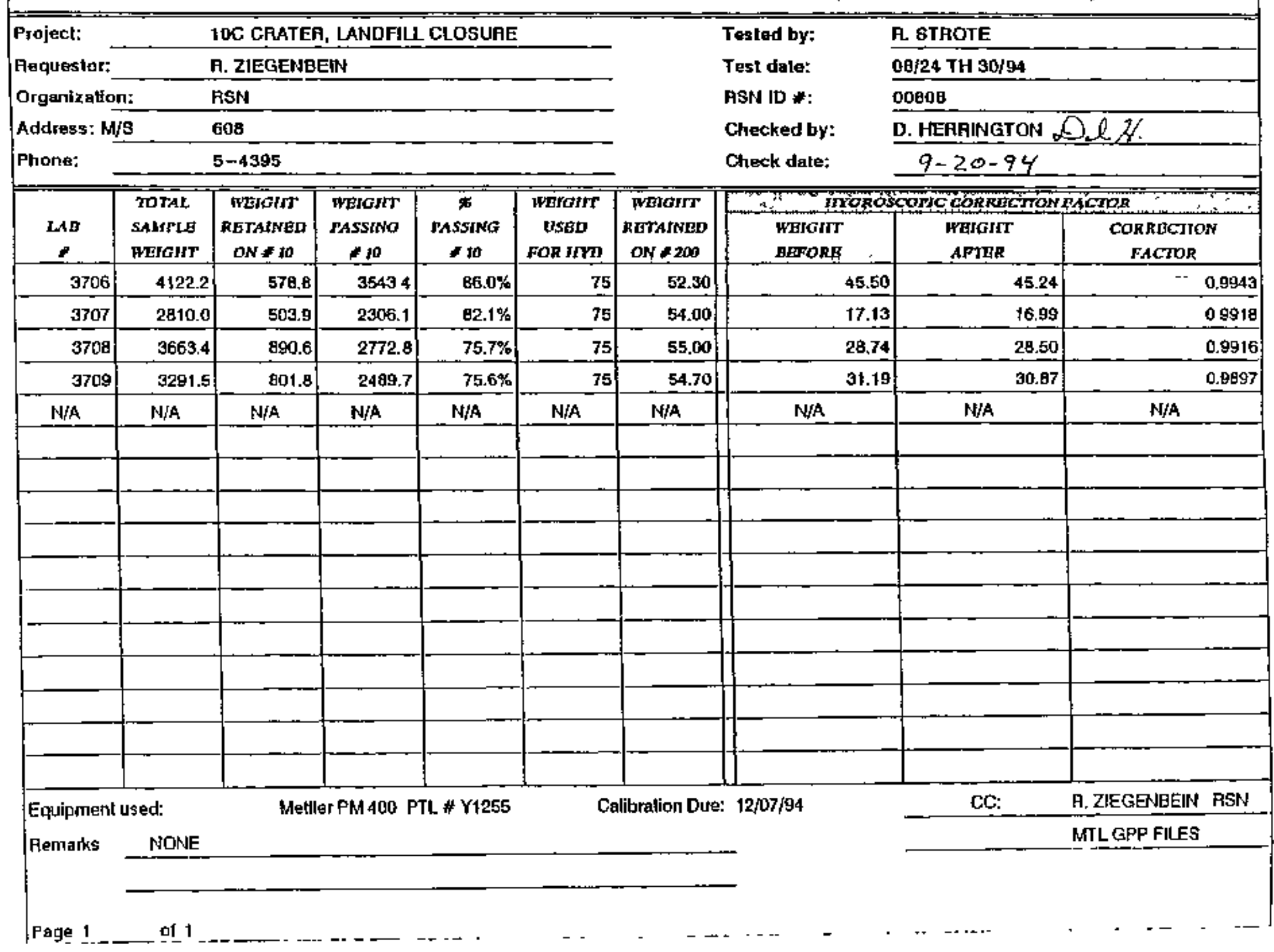




\section{TABLE 4. GRADATION (ASTM DA22-9O)}

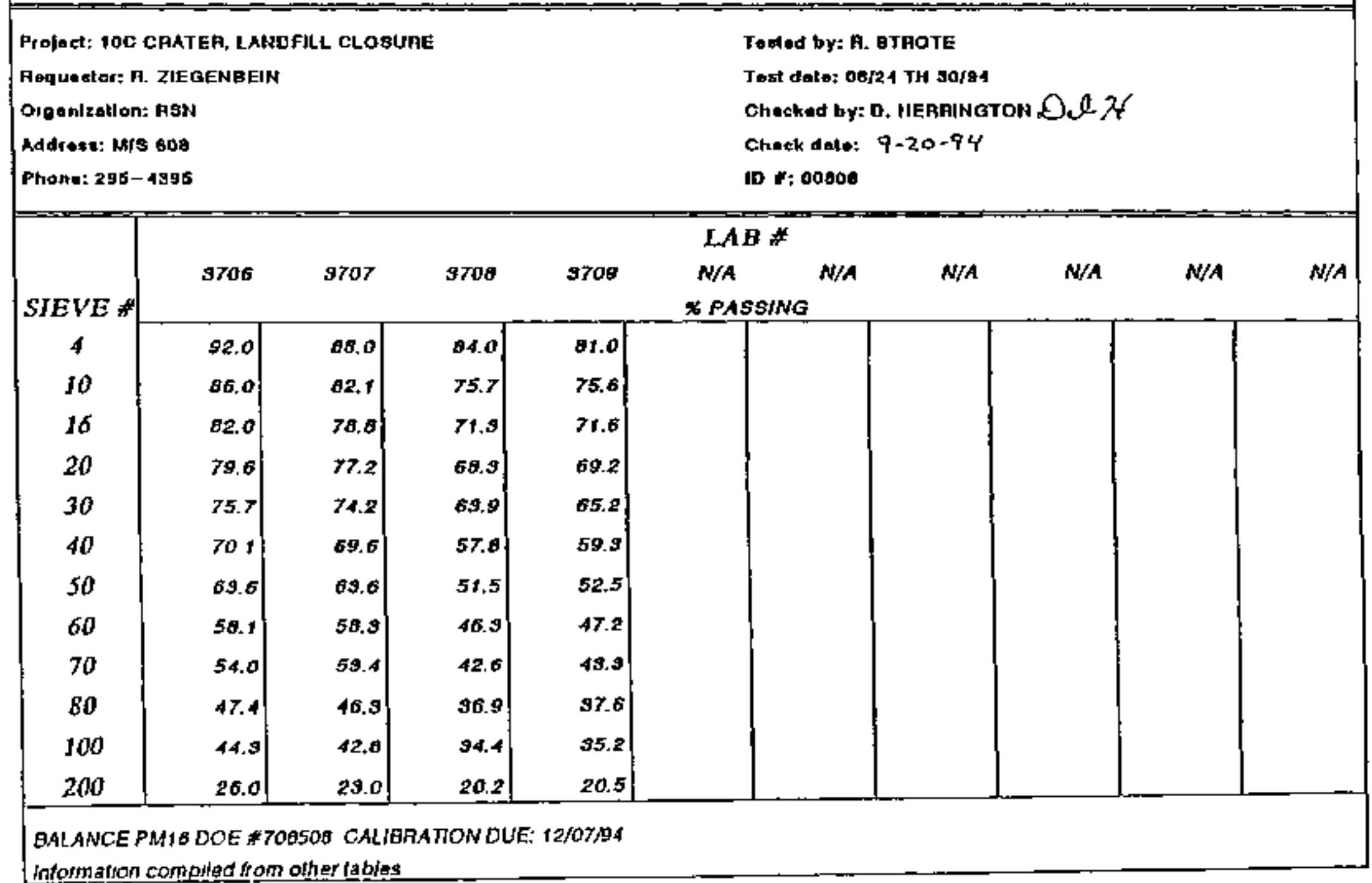




\section{PERCENTAGE OF COMPOSITE SAMPLE}

SAMPLE \# 3706 ih 3709

占

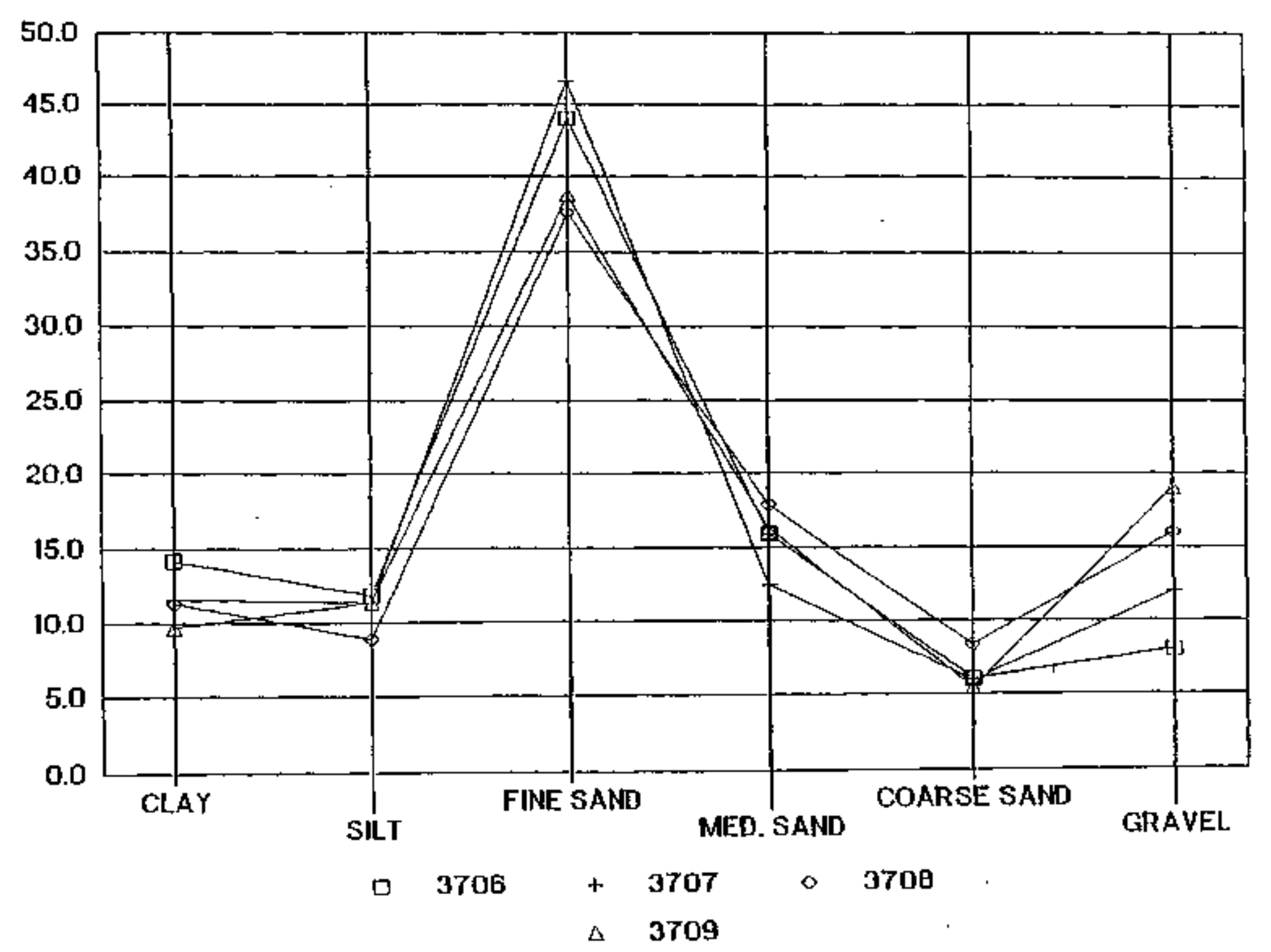


HYDROMETER ANALYSIS (ASTM D422-90)

SAMPIE \# 3706

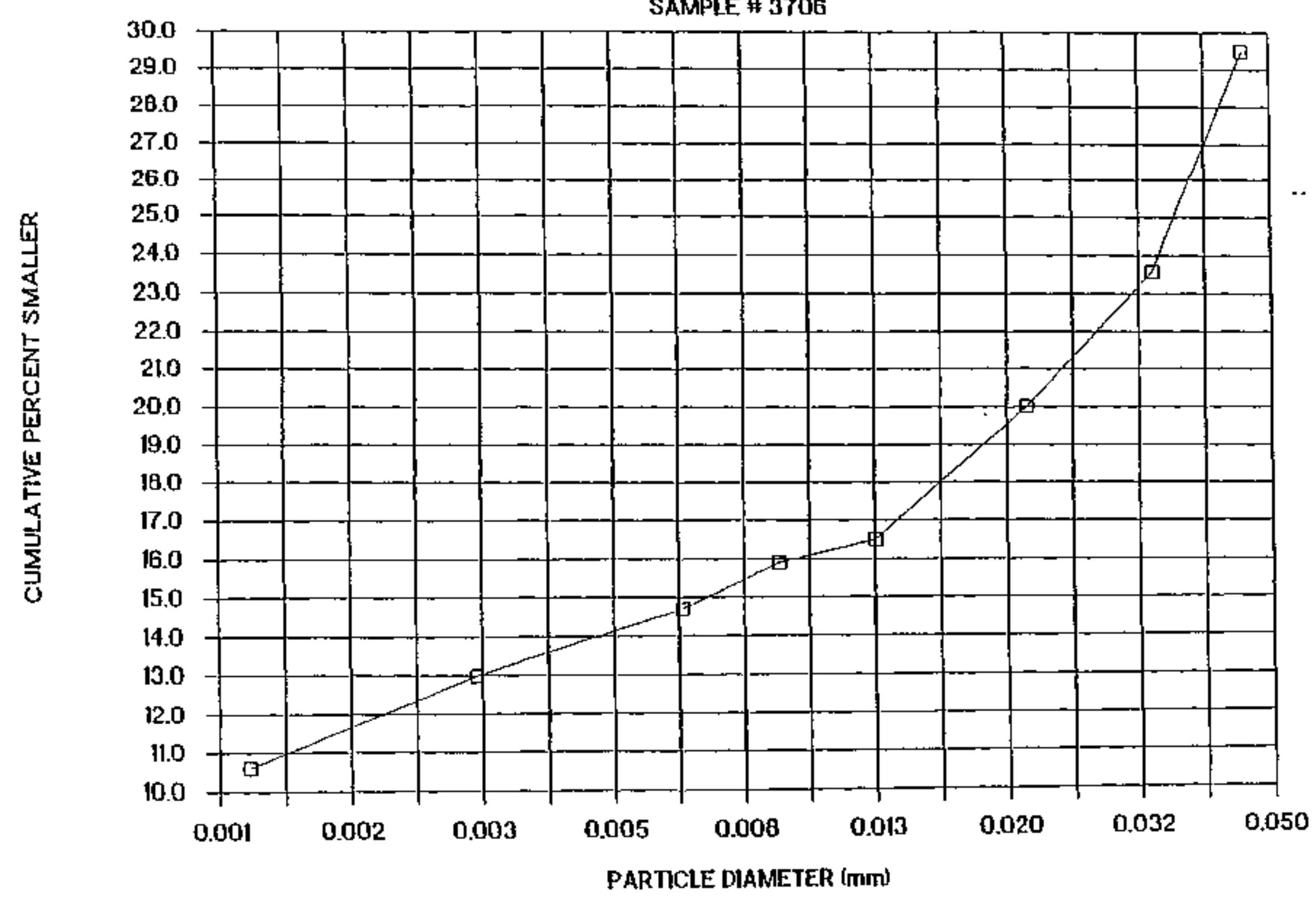


HYDROMETER ANALYSIS (ASTM D422-90)

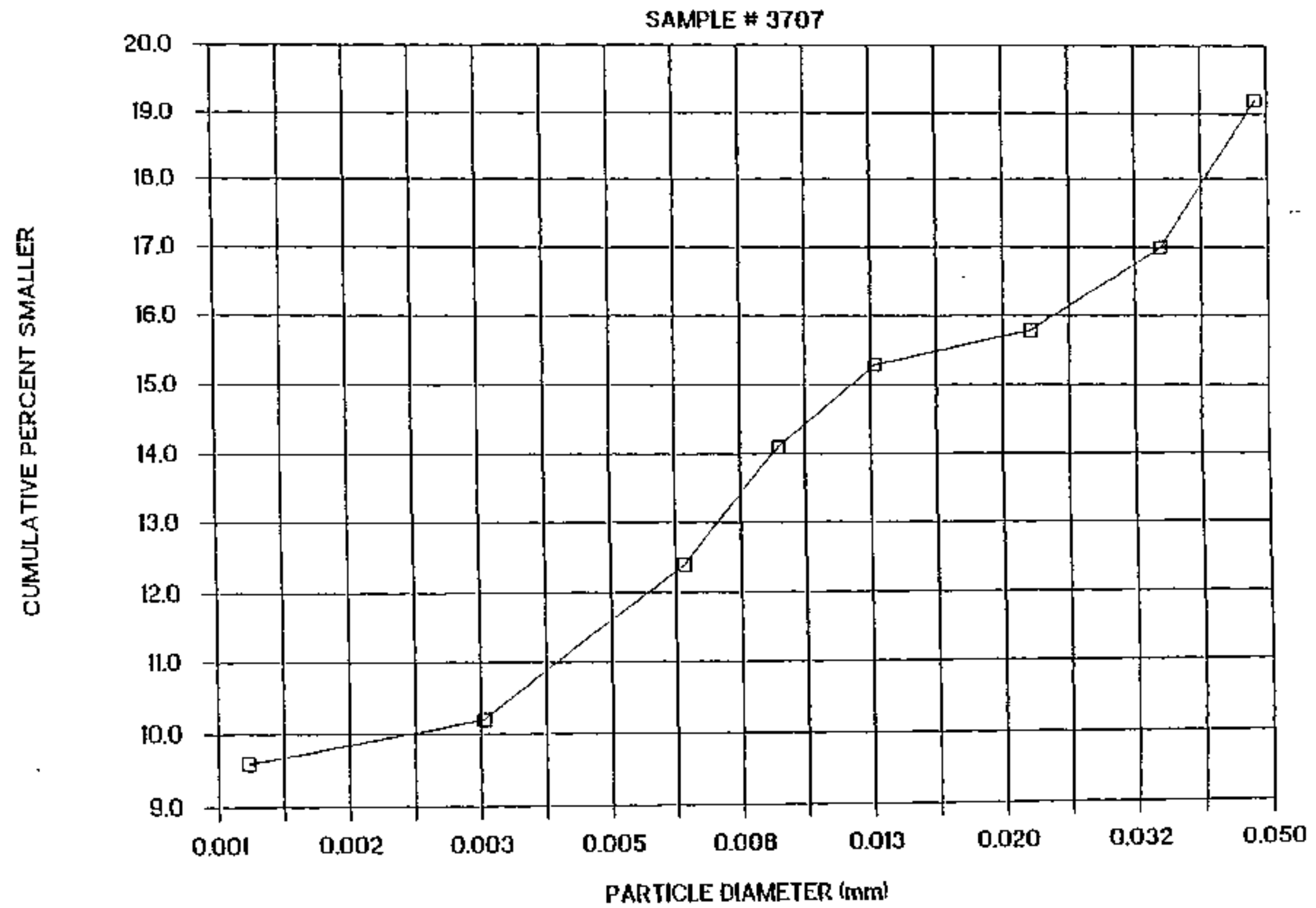


HYDROMETER ANALYSIS (ASTM D422-90)

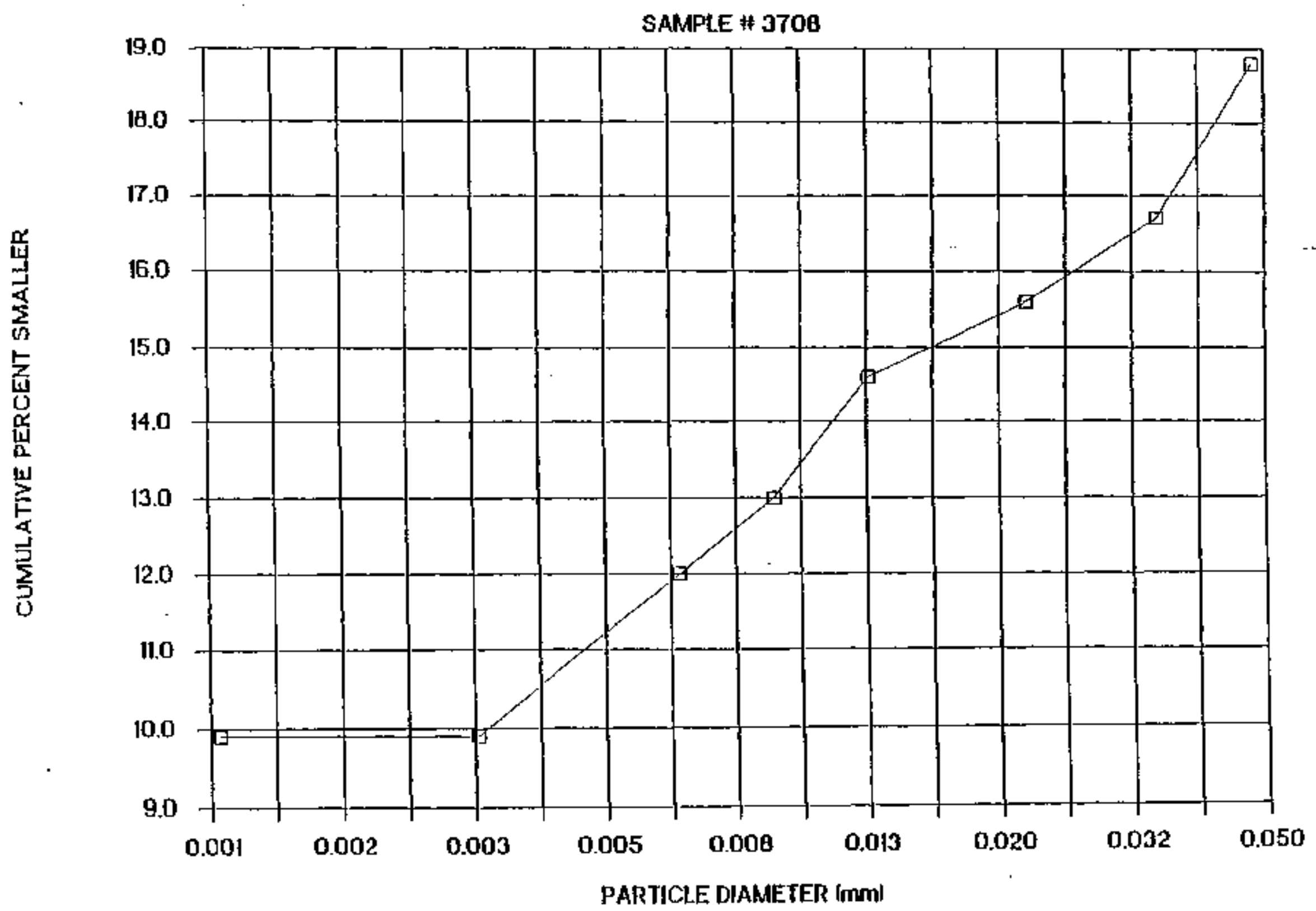




\section{HYDROMETER ANALYSIS (ASTM D422-90)}

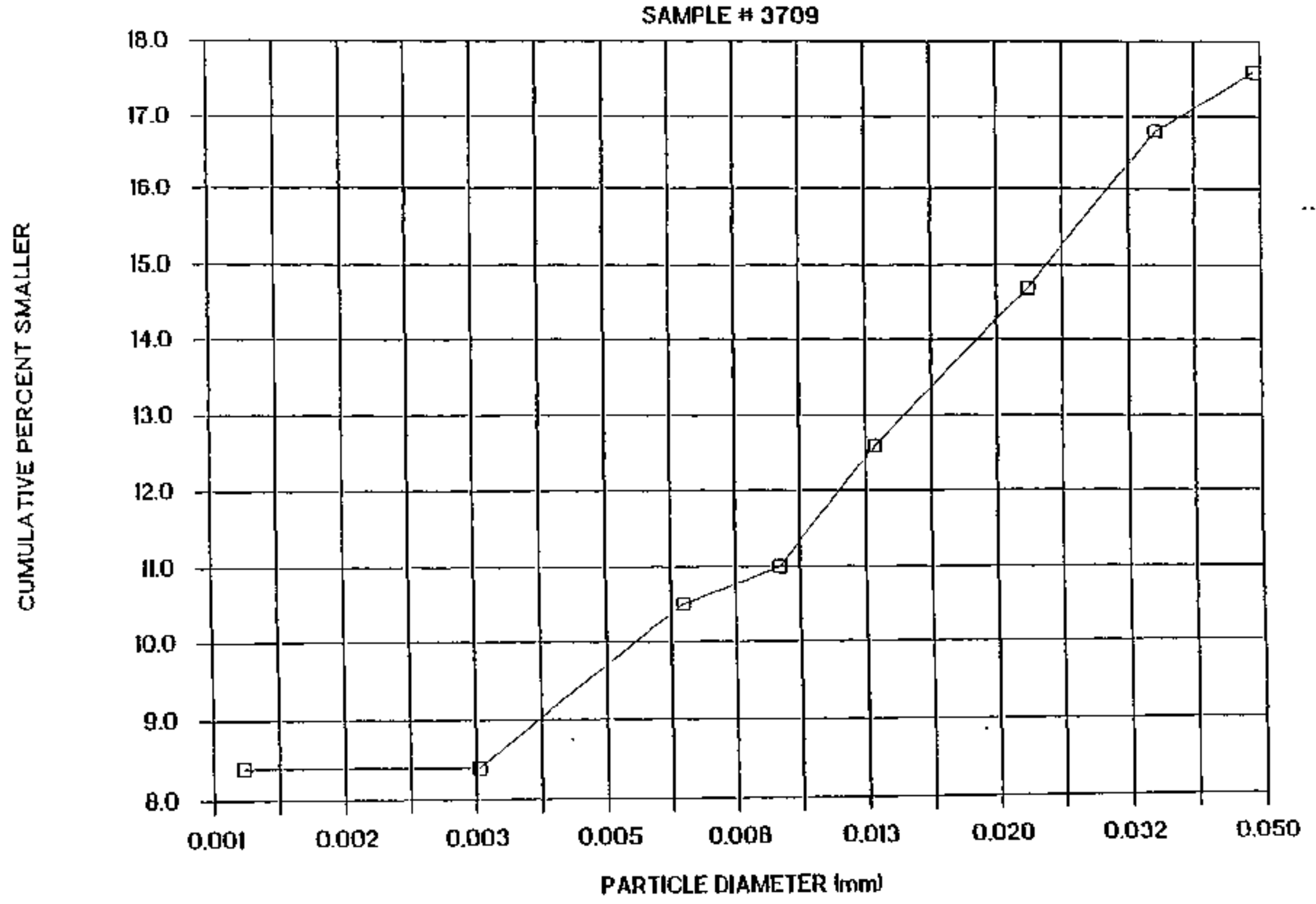


Raytheon Services Nevada

Materials Testing Laboratory

Nevada Test Site

P.O. Box 328, M/S 607 Pr: (702)-295-6669

SOIL PERMEABILITY TO MERCURY TAP WATER

ASTM D 2434-68 (Reapproved 1974)

Standard Test Method tor Fermeabillty of Grantlar Soils (Constant Head)

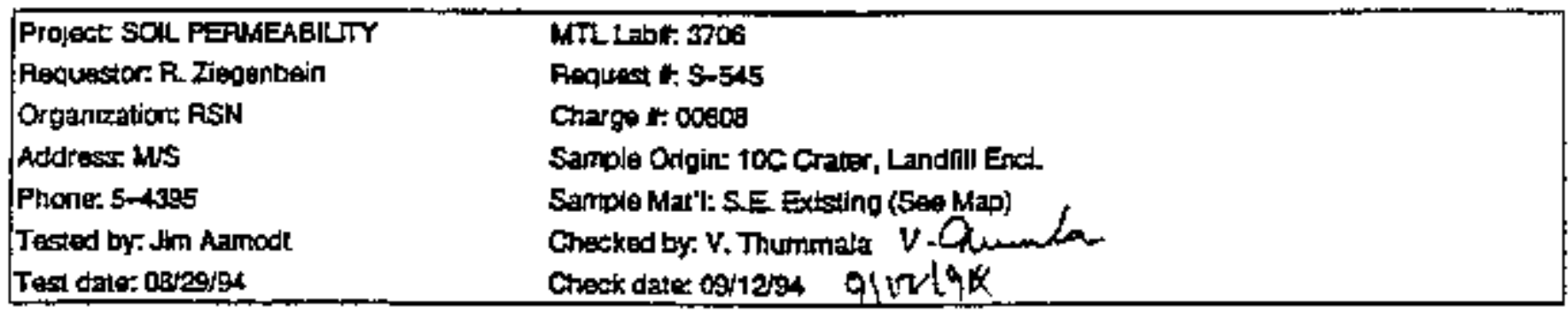

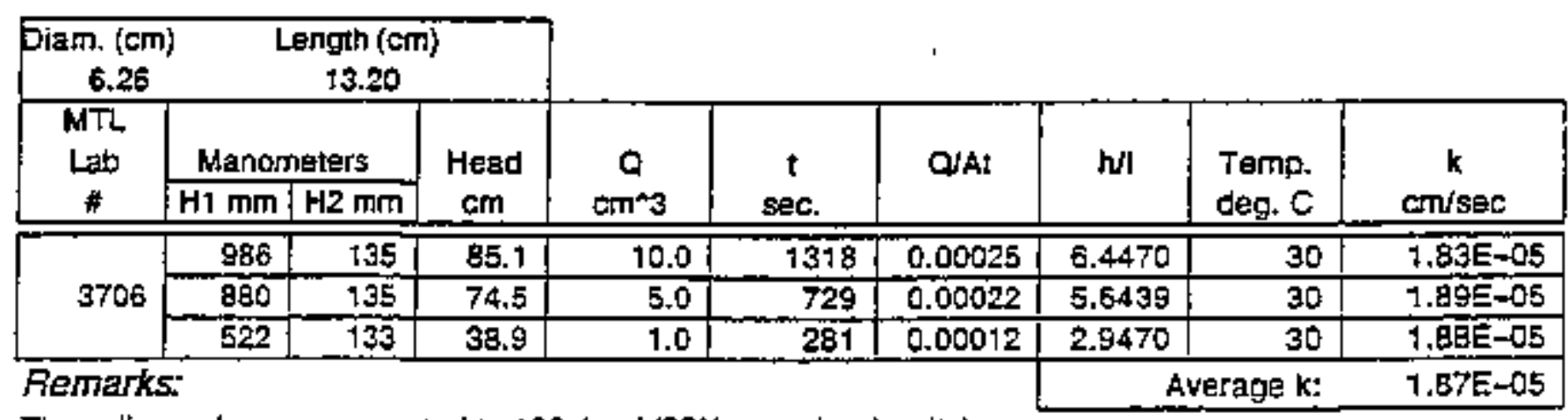

The soll sample was compacted to 106,4 pof (\$5\% max dry density),

Equipment Usad: $\quad$ Calibration Due:

Mettier PM6100 Balance. PTL W- $1723 \quad 12 / 07 / 94$

Digital thermometer, PJLW-3789 09/02/94

Digital Casjper, FTL-Y11135 09/29/94 
Raytheon; Services Nevada

Materials Testing Laboratory

Nevada Test Site

P.O. Bax 328, wS 607 Ph: (702)-295-6669

\section{SOIL PERMEABILITY TO MERCURY TAP WATER}

ASTM D 2434-69 (Aeapproved 1974)

Siandard Test Method for Permeabllity of Granular Soils (Constant Head)

\begin{tabular}{|c|c|}
\hline Project SOR PEFUEABILTY & MTL Labll, 3707 \\
\hline Fequestor: RL Zegenbein & Aequest \# S-545 \\
\hline Organdzation: RSN & Charge *, 00808 \\
\hline Addrees: M/S & Sumple Origire 10C Crats، tantrotill Enel. \\
\hline Phone: 5-6395 & Sampio Mar'l: N.E Existurg (Soe Map) \\
\hline Tested by: Jint Aamodt & Checked by. V. Thummala V. When \\
\hline Test date; $08 / 29 / 94$ & -Check dare: 09/12/94 \\
\hline
\end{tabular}

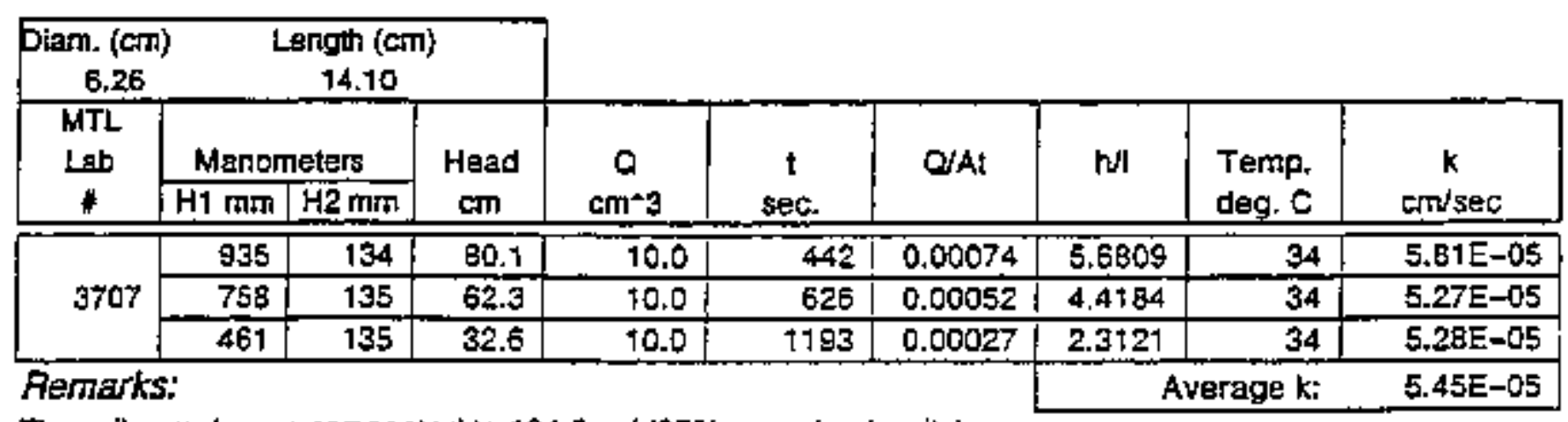

The soil sample was compacted to 104.5 pet (95\% max dry density).

Equipmem Used: $\quad$ Calibration Due:

Metzler PM6100 Balance, PTL W-1723 $12107 / 94$

Digital thermometer, PTL W-319g 09/02/94

Digntal Caliper, PTL-Y11135 09/29/94 
Raytheon Services Nevada

Materiais Testing Laboratory

Nevada Test Site

P.D. E0x 32B, M/S 607 Ph: (702)-295-6669

\section{SOIL PERMEABILITY TO MERCURY TAP WATEF}

\section{ASTM D 2434-68 (Reapproved 1974)}

Standard Test Method for Permeability of Granutar Soils (Constant Head)

Project: SOIL PERMEARILTY

Pequesior: R Zeganbein

Organization: RSN

Address MUS

Procie: 5-1395

Tested by Jim Aamod

Test date: corrarsa
MTL 1, atk; 3700

Mequest \&. 5-545

Charee 400008

Sumpin Origin 10C ctalex, Landrí Encl.

Sample MartE N.W. Existing (See Map)

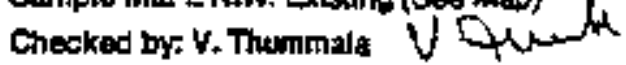

Check daye; 09/12rs

\begin{tabular}{|c|c|c|c|c|c|c|c|c|c|}
\hline $\begin{array}{c}\text { Dlam. (cn } \\
6.26\end{array}$ & I & $\begin{array}{l}\text { ength (c) } \\
13.27\end{array}$ & & & & & & & \\
\hline $\begin{array}{l}\text { MTL } \\
\text { Lab }\end{array}$ & Manor & leters & Head & Q & $t$ & D/At & $\mathrm{h} / \mathrm{t}$ & Temp. & $k$ \\
\hline$\#$ & $\mathrm{H} 1 \mathrm{~mm}$ & $\mathrm{H} 2 \mathrm{~mm}$ & $\mathrm{~cm}$ & $\mathrm{~cm}^{\wedge} \mathrm{S}$ & sec. & & & deg. C & convsec \\
\hline & 930 & 135 & 79.5 & 7.0 & 2302 & 0.00010 & 5,9910 & 30 & 7.96E-06 \\
\hline 3708 & 833 & 135 & 69.8 & 6.0 & 2291 & 0.00009 & 5.2600 & 30 & $7.71 E-06$ \\
\hline & 755 & 135 & 62.0 & 70.0 & 4207 & 0.00008 & 4.6722 & 30 & $7.88 \mathrm{E}-06$ \\
\hline Remarks & & & & & & & & erage $x:$ & 7.82E-06 \\
\hline
\end{tabular}

The soll sample was compacted to $1+1.1 \mathrm{ped}$ (95\% max dry density).

Equipment Used:

Calibration Due:

Metter PM6100 Balance, PTL W- $\$ 723$

Digital thermometer, PTL W-3199

$1207 / 94$

Digital Cal.per, PTL-Y11135

$09102 / 94$

$09 / 29 / 94$ 
Raytheon Services Nevada

Materials Testing Laboratory

Nevada Test Site

P.D. Box 328, M/S 607 Ph: (702)-295-6669

\section{SOIL PERMEABILITY TO MERCURY TAP WATER}

ASTM D 2434-68 (Reapproved 1974)

Standard Test Method for Permeability of Granutar Solis (Constant Head)

\begin{tabular}{|c|c|}
\hline Propact SOIL PEFMEABIUTY & NIL Lab*t: 3709 \\
\hline Pequestor: R. Teqenbetn & Request $\div$ \$-545 \\
\hline Organzation FSN & Cnarge *. Oopos \\
\hline Address: HWS & Samphi Ong!n: toC Croter, Landill Enel. \\
\hline Phona: 5-4395 & Sample Mat'I: S.W. Existung (Sog Map) \\
\hline Teated by. Jim Aamodt & Checked by: $V$. Thurntrata $V$ \\
\hline Teas date: 09/02je4 & Check date: 09 ry 2194 \\
\hline
\end{tabular}

\begin{tabular}{|c|c|c|c|c|c|c|c|c|c|}
\hline $\begin{array}{c}\text { Pram. (cm } \\
6.25\end{array}$ & & $\begin{array}{c}\text { Bngth (cr } \\
13.12\end{array}$ & & & & & & & \\
\hline $\begin{array}{l}\text { MTL } \\
\text { Lab }\end{array}$ & Manor & ieters & Head & 0 & $t$ & O/At & $h /$ & Temp. & k \\
\hline$\#$ & H1 $\mathbf{m m}$ & $\mathrm{H} 2 \mathrm{~mm}$ & $\mathrm{~cm}$ & $\mathrm{~cm}^{2} 3$ & sec. & & & $\operatorname{deg} . C$ & $\mathrm{crn} / \mathrm{sec}$ \\
\hline & 968 & 135 & 83.3 & 5.0 & 1579 & 0.00010 & 6.3491 & 31 & $7+81 E-D 6$ \\
\hline 3709 & 890 & 135 & 75.5 & 40 & 1382 & 0.00009 & 5.7546 & 31 & $7 . B 8 E-06$ \\
\hline & 755 & 135 & 62.0 & 5.0 & 2107 & 0.00008 & 47255 & 30 & $7.87 E-06$ \\
\hline Femarks & & & & & & & & erage $k$ & $7.85 E-06$ \\
\hline
\end{tabular}

The soll sampie was compacted to 105.3 pct (95\% max dry density).

Equipment Used:

Mettler PM6100 Ealance, PTL W-1723

Digital thermometer. PTL W-3+9g

Digital Calıper, PTL-Y11135
Calibration Due:

$12107 / 94$

$09 / 0294$

$09 / 29 / 94$ 
FIUCTOR TEST

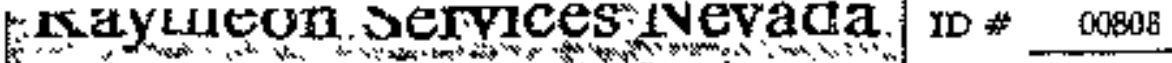

ASTM D 1557-91

: MATERLAIS TESTTYGYSBORATORY:

METIOD $C$

$\because$ NEVADA TEST STIE

LAB \# 3706

DATE 08/29/94

Project: LDCCRATER.LANDFLL CLOSURE Requested by: R. ZZEGENBEN Uset/Agency RSN

Sampled by: D. ANDERSON Date sampied D0/17/94_ Material: S.E. EXISTING (See MLp)

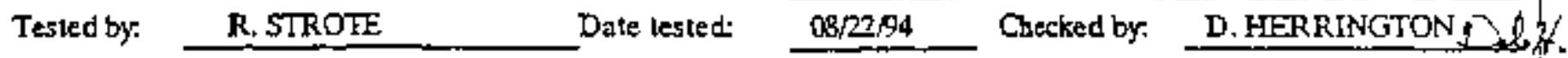

\begin{tabular}{|c|c|c|c|c|c|c|c|}
\hline \multicolumn{2}{|r|}{ TRIAL } & 1 & 2 & 3 & 4 & 5 & 6 \\
\hline \pm & $W_{t \text {.nole }+ \text { wet scil }}$ & 67660 & 69985 & 7128.0 & 7075.9 & 71285 & N/A \\
\hline 2 & $W_{L}$ motd & 2956.5 & 28565 & 28565 & 2856.5 & 28565 & N/A \\
\hline 3 & W. wet soil & 39095 & 4142.0 & 42715 & 4219.4 & 4272.0 & $N / A$ \\
\hline 4 & Wet Dennly, PCF & 1149 & 121.8 & 125.6 & 124.0 & 125.6 & $\mathrm{~N} / \mathrm{A}$ \\
\hline 5 & Molsture Tare 8 & 1 & 2 & 3 & 4 & 5.0 & $N / A$ \\
\hline 6 & W! wel goil + tare & 13173 & 1390.7 & 1380.5 & 13970 & 1671.6 & $\mathrm{~N} / \mathrm{A}$ \\
\hline 4 & Wh dry sort + lave & 12213 & 1259.0 & 12273 & 1223.2 & 14.36 .2 & $N / A$ \\
\hline 8 & Wh motsiure & 960 & 131.7 & 153,2 & 173.8 & 235.4 & N/A \\
\hline 9 & Whe lere & 16.9 & 169 & 16.9 & 16.9 & 16.9 & $N / A$ \\
\hline 10 & wi dy zail & 1204.4 & 1242.1 & \pm 210.4 & 12063 & 14193 & N/A \\
\hline 11 & F Mouture & 8.0 & 10.6 & 12.7 & 14.4 & 16.6 & $\mathrm{~N} / \mathrm{A}$ \\
\hline 12 & Dry Deusity, $\mathrm{PCP}$ & 106.4 & 110.1 & 111.5 & 108.4 & 107.7 & $N / A$ \\
\hline
\end{tabular}

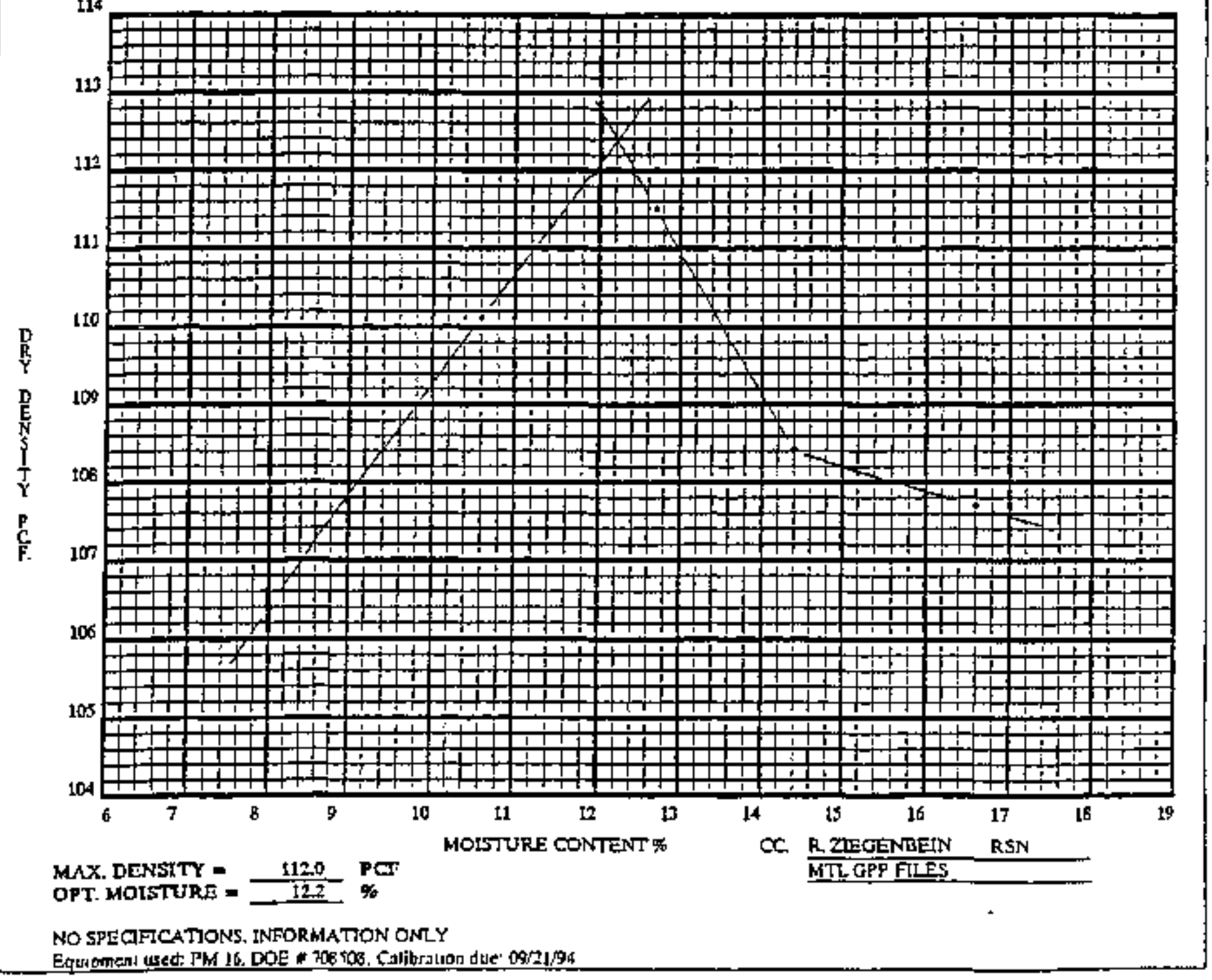


MROCTOR TEST

ASTM D 1557-91

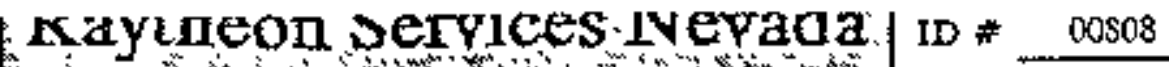

MEIIIOD C. MATFRIALSTESTENGIABORATURY

I.AB \# 3708

NEVADA TEST.SIEE

Project 10C CRATER. LANDFLL CIOSURE Requested by: R. ZMEGENEEIN USET/Agengr. RSN

Sampled by: D. ANDERSON _ Date samplet 08/17/94 Material: N.W. EXISTING (Sec Map)

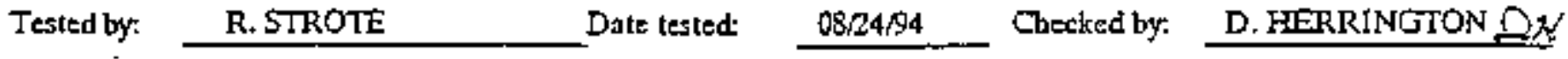

\begin{tabular}{|c|c|c|c|c|c|c|c|}
\hline \multicolumn{2}{|r|}{ TRLAL } & 1 & 2 & 3 & 4 & 5 & 6 \\
\hline 1 & Wh, mold + wet soll & 7087.5 & 71963 & 72995 & 2903 & 0.0 & $N / A$ \\
\hline 2 & Wh. moidd & 28565 & 2856.5 & 2856.5 & $2856 . \overline{5}$ & 0.0 & $N / A$ \\
\hline 3 & $W_{1}$ wet soi] & 4231.1 & 4339.8 & 4443.0 & 4433.8 & 0.0 & N/A \\
\hline 4 & Wet Densily. PCF & 124,4 & 127.6 & $130,6$. & 130.3 & 0.0 & $N / A$ \\
\hline 5 & Moisture Tare * & 1 & 2 & 3 & 4 & 0.0 & $\mathrm{~N} / \mathrm{A}$ \\
\hline 6 & Wh wel soil + tare & 1361.4 & 1448.0 & 1515.0 & 1582.0 & 0.0 & $\mathrm{~N} / \mathrm{A}$ \\
\hline 7 & WL dry soil + tart & 1266.1 & 1322.1 & 1353.7 & 13952 & 0.0 & $N / A$ \\
\hline 8 & Wh motature & 953 & 125.9 & 1613 & 186.8 & 0,0 & N/A \\
\hline 9 & Wh lure & 16.9 & 1699 & 16.9 & 16.9 & 0.0 & $\mathrm{~N} / \mathrm{A}$ \\
\hline 10 & $\mathbf{W} ! d r y$ g口i & 1249.2 & 13052 & 13.36 .8 & 13783 & 0.0 & $\mathrm{~N} / \mathrm{A}$ \\
\hline 12 & \% Moisturs & 7.6 & 9.6 & 12.1 & 13.6 & 0.0 & $\mathrm{~N} / \mathrm{A}$ \\
\hline 12 & Dry Dootily, rCF & 125.6 & 1163 & 2165 & 114.8 & 0.0 & $\mathrm{~N} / \mathrm{A}$ \\
\hline
\end{tabular}

121

120

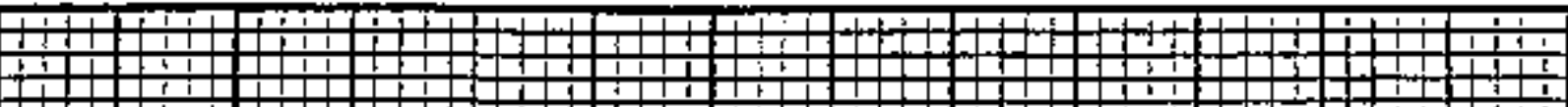

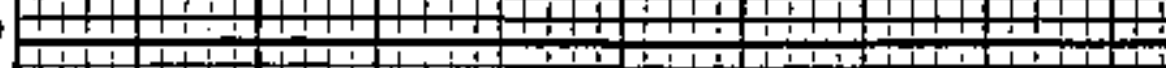

129

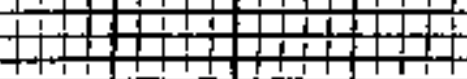

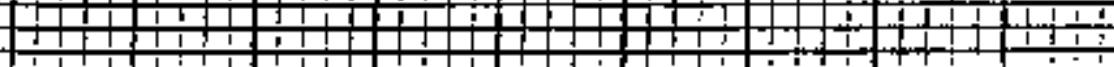

130

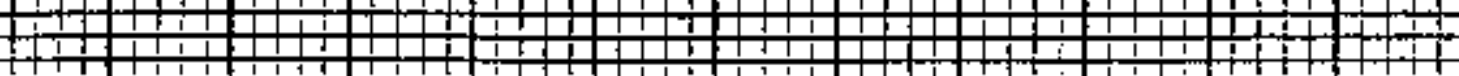

17

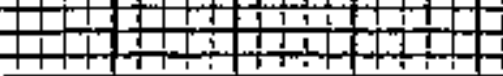



116

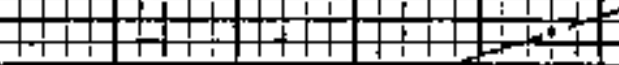

$1+\frac{1}{1+1}$

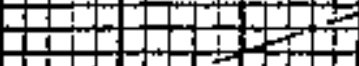

119

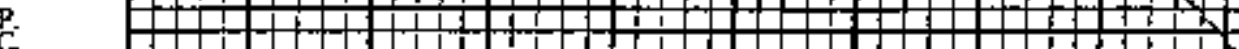

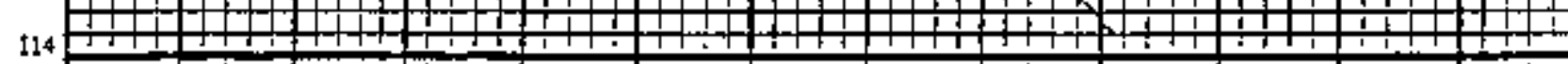

+1

II3

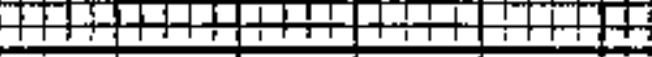

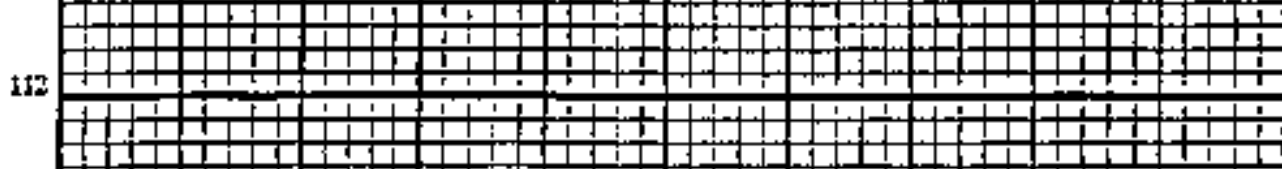

211

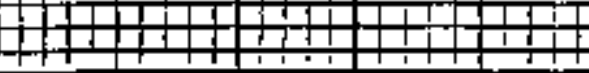

679

in

13

14 59

is

16

17

MaX DDNSTYY = $\frac{116.9}{\text { PCT }}$

MOISTURE CONTENT\%

OPT, MOISTURE $=\frac{11.5}{1.5} \%$

MTLFPFIES 


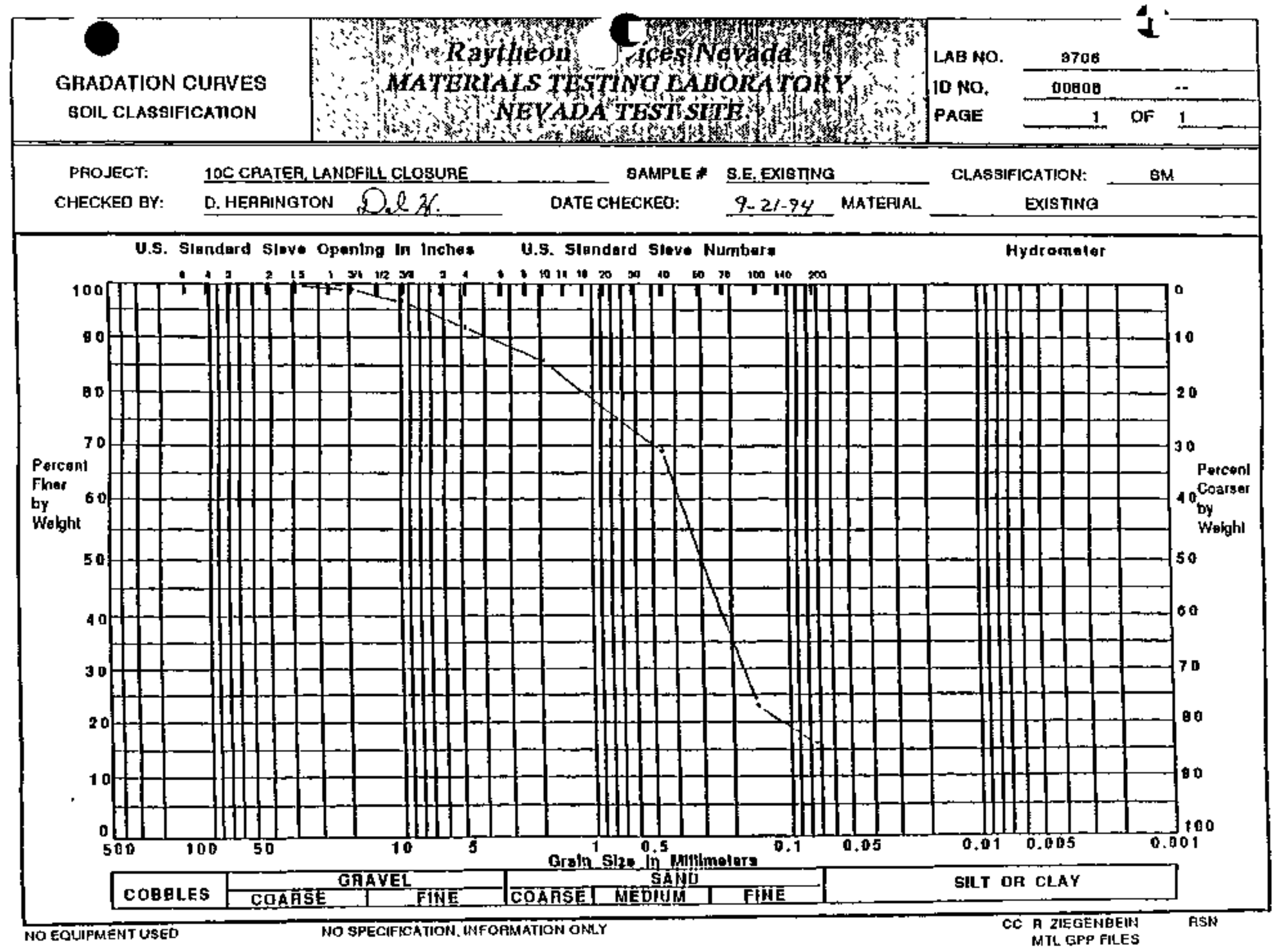




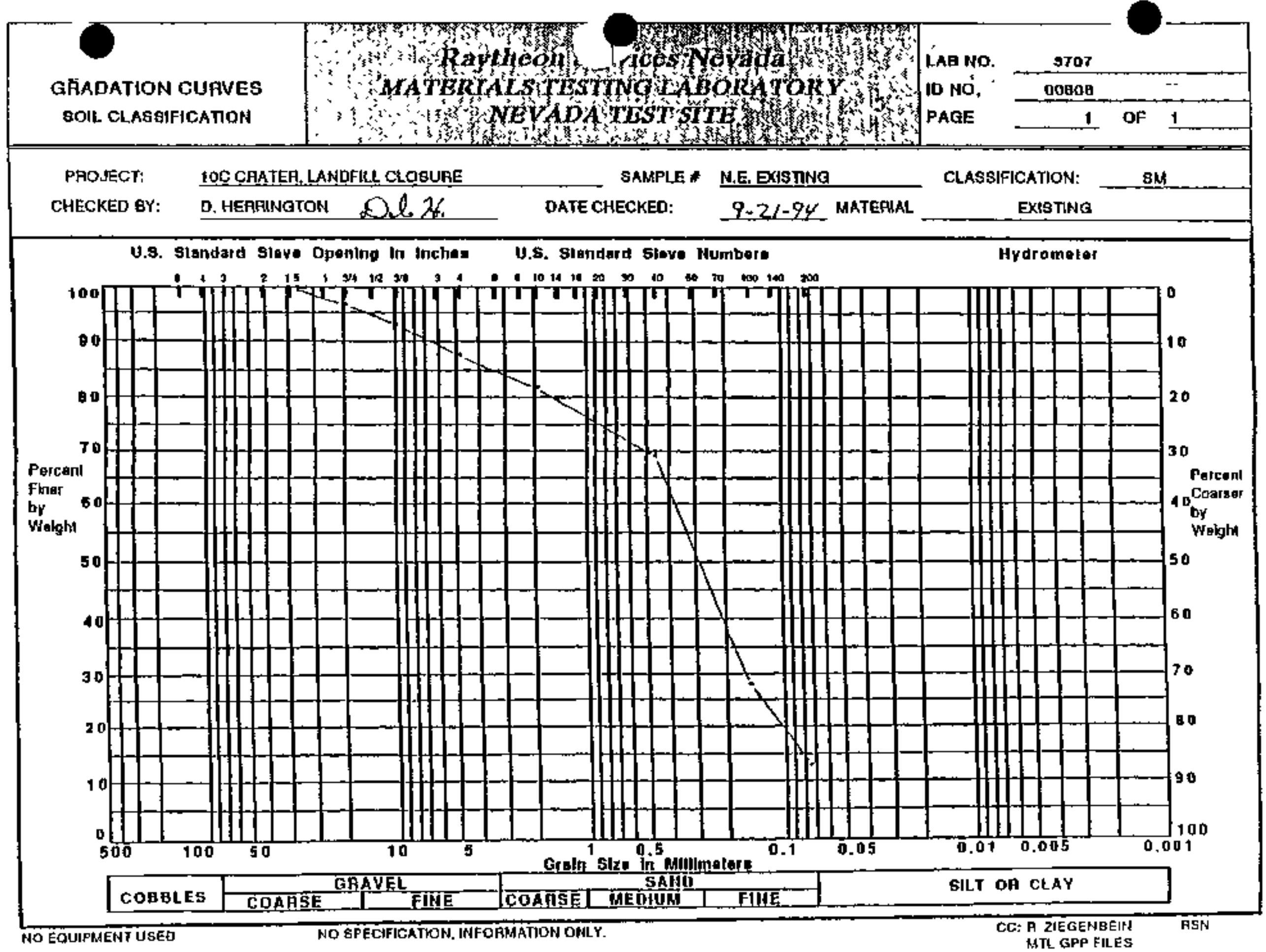




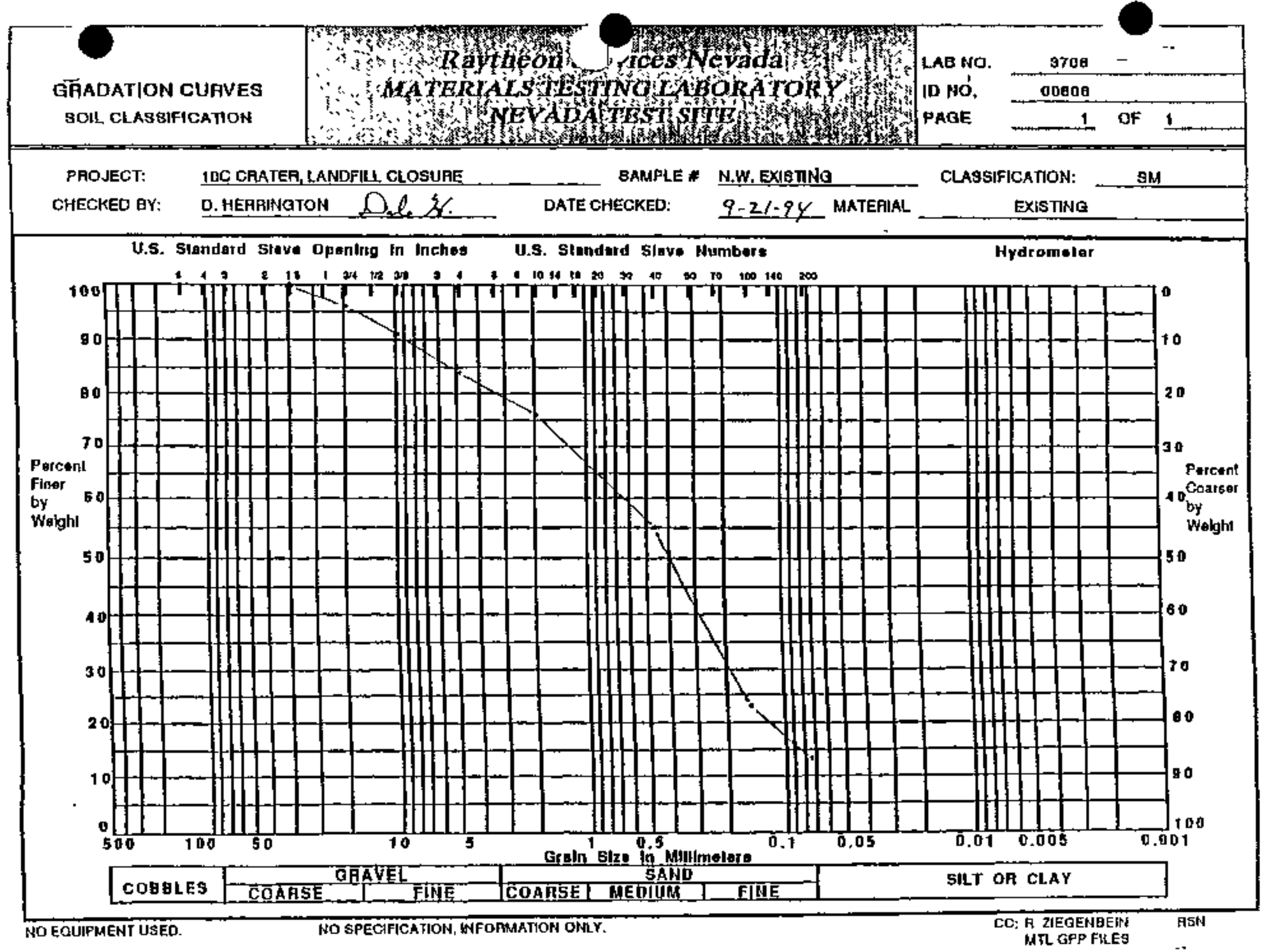




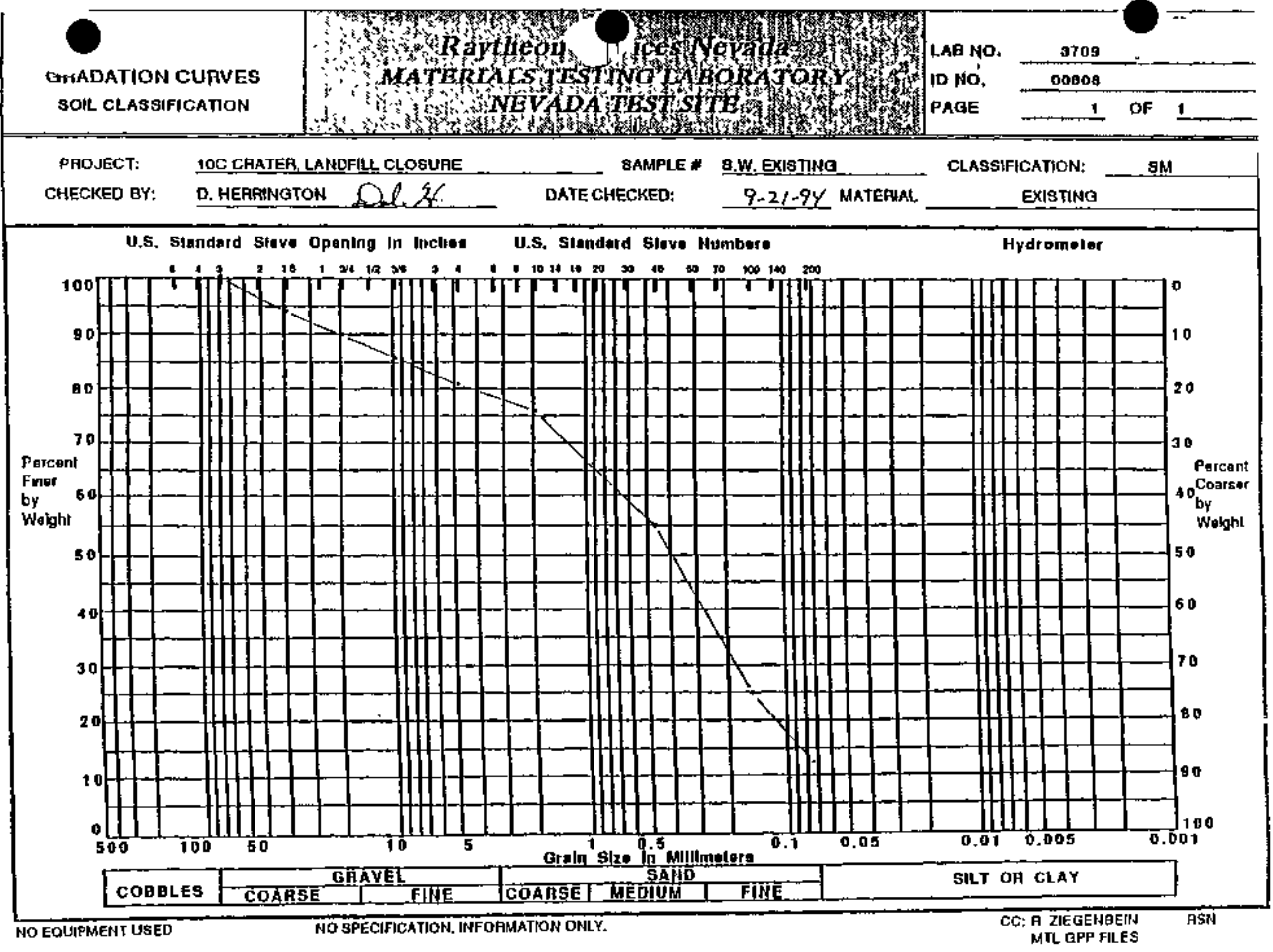




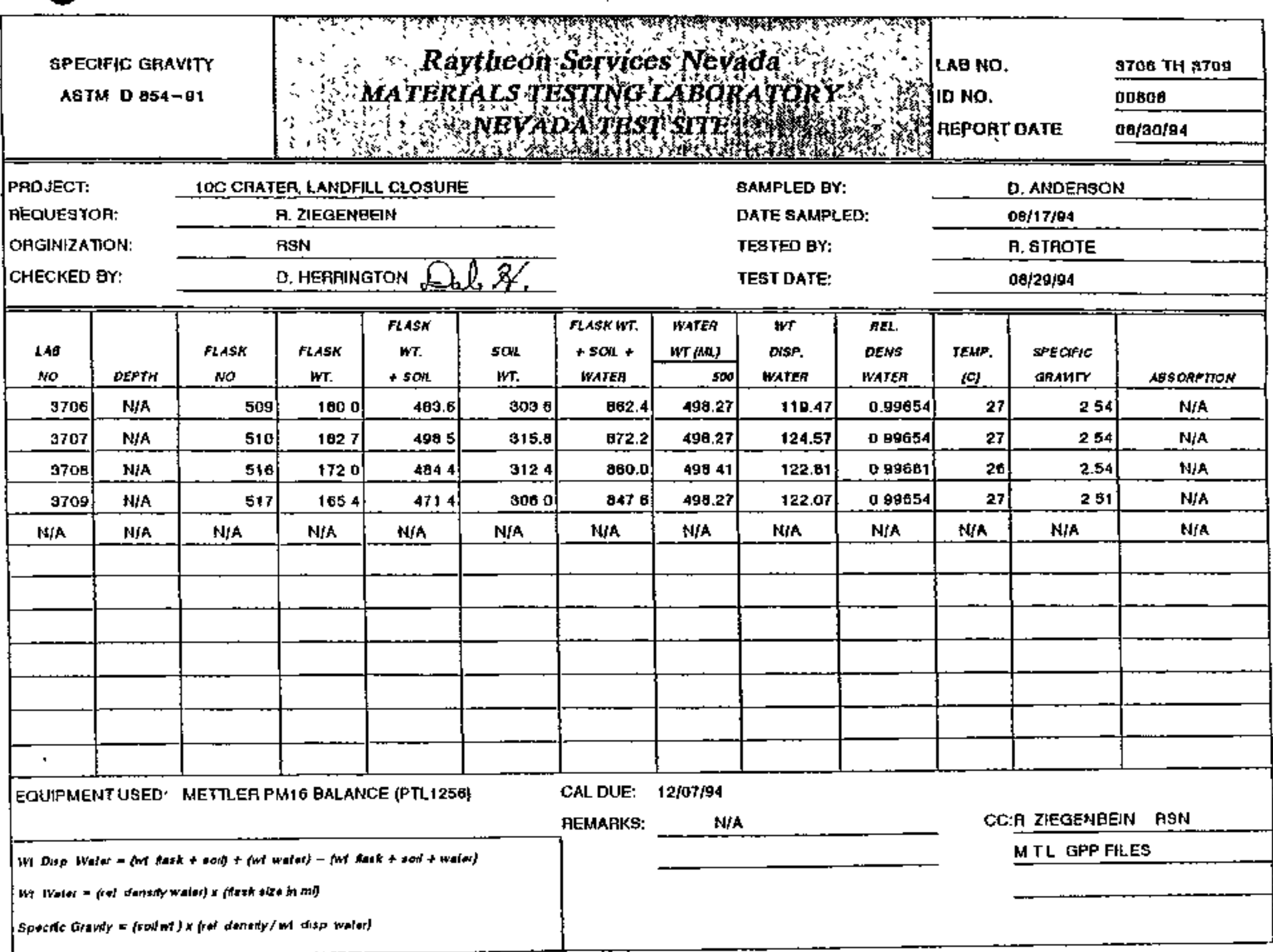

